\title{
Distribution of marine, benthic, shell bearing gastropods along the Norwegian coast
}

\author{
Tore Hoisæter
}

Høisæter, T. 2009. Distribution of marine, benthic, shell bearing gastropods along the Norwegian coast. Fauna norvegica 28: 5-106.

Based on literature data and my extensive material from along the coast, the distribution of shell bearing marine, benthic gastropods known from Norwegian waters, is outlined. The geographic area covered goes down to c. $1200 \mathrm{~m}$ on the continental slope, and extends from the Swedish border in the south to the Russian border in the north-east. On the slope the distribution is restricted to an area east of $0^{\circ}$, and south of $72^{\circ} \mathrm{N}$. Neither the North Sea nor the western 'slope' of the Norwegian Trench are included. Systematics and nomenclature follow CLEMAM (Check List of European Marine Mollusca) closely. The emphasis is on the distribution of each species within the designated area, but taxonomic and nomenclaturial problems are discussed wherever considered relevant.

Altogether 365 species level taxa are included, of which 326 are considered as definitely belonging to the Norwegian fauna. The rest are recorded as doubtful, either because only empty shells have been found, or their confirmed distribution falls outside the limits here defined. Of the 'species' included, I consider at least 18 to be undescribed, while another 16 were described from Norwegian material after Høisæter (1986) was published. The northern distributional limit is extended for 47 species, while 11 species have received a new southern limit.

Sixty six species have a generic name diferent from the one used in Høisæter (1986), while 35 species have another specific name. All changes are listed in the main part of the article, and references are given to the sources for the changes.

Four faunal components are recognized: a slope component, species mainly found in negative temperatures on the continental slope, between 500 and $1200 \mathrm{~m}$; an Arctic component, species in Norway almost exclusively found in East Finnmark; a group of species in Norway found only or mainly on the Skagerrak coast or in Oslofjorden; and finally the main group found along most of the coast.

Keywords: Annotated check-list, distribution, new records, Norway, Norwegian Sea, Mollusca, Gastropoda, snails.

Tore Høisceter, University of Bergen, Department of Biology, P.O. Box 7800, N-5020, Bergen, Norway

E-mail:tore.hoisater@bio.uib.no

\section{INTRODUCTION}

The distribution of the molluscan fauna along the Norwegian coast was summarised in Høisæter (1986). Since that check list was published, the systematics of the main groups have been changed fundamentally, and several species have been added to the Norwegian marine fauna. In addition scores of species have changed their 'valid' names. Most of these changes are incor- porated in Clemam (Check List of European Marine Mollusca - www.somali.asso.fr/clemam), although this compilation does not include information on the distribution of the various species around the European coasts. Most of the changes of relevance to the Norwegian fauna are due to the diligent work of Anders Warén, published in various reports (Bouchet \& Warén 1985, 1986, 1993; Warén 1989, 1991, 1992, 1993, 1996a, b). In these reports tens of new species have been introduced, and 
scores of nomenclatural changes have contributed to render the 1986 check list highly obsolete. However, the information in the various publications of Warén is not suitable as a substitute for the obsolete check list, the information being scattered rather unsystematically between different reports, and the distribution given only in very broad terms. In addition, Norwegian records are hidden among records from south-western Iceland, the bathyal Atlantic, and more Arctic areas.

The present report is attempting to fill part of this gap by presenting an up-to-date survey of the nomenclatorial and taxonomic changes and more recent distributional data on all the shell-bearing gastropods so far recorded from Norwegian waters. The groups of gastropods included are all species of benthic gastropods with external shells, as well as those with internal shells, except a few species traditionally included in the group Notaspidea.

Over the last 40-50 years I have amassed a considerable material (more than 100000 live caught specimens representing around 230 species, as well as more than 20000 empty shells) collected in various localities on the Norwegian coast from the Russian border south to $60^{\circ} \mathrm{N}$. Thus I have had the opportunity to study some 310 species, in many cases hundreds or thousands of specimens of each, permitting me to evaluate the variability of many species. This material has never been compiled and presented in a coordinated way, and might be a valuable basis for updating the check list (Høisæter 1986) and at the same time establish a bench-mark for any future faunal changes. The work is largely based on the material I have studied personally and for which I can 'vouch for' the identifications. However to extend the usefulness of the work, I have included information from two valuable reports by Wikander (Wikander 1989, 1990) based on part of his collections from the Skagerrak coast. In addition I have performed a comprehensive literature survey to assure an as accurate rendition as possible on the present and past distribution of each species. Only published distributional data are included (the two reports of Wikander cited above are regarded as publications for this purpose, as they are the only comprehensive recent surveys of marine molluscs on the Skagerrak coast).

Roughly $85 \%$ of my live caught material stems from several dedicated studies of the fauna in the vicinity of the Marine
Biological Station of the University of Bergen (around $60^{\circ}$ to $60^{\circ} 30^{\prime} \mathrm{N}$, included in the text as the 'Espegrend area'), during the 60 -ties, 70 -ties, and partly during the 80 -ties and early 90 -ties. These investigations were performed partly in collaboration with fellow marine biologists from the University of Bergen. Incidental records from the 50-ties and from some supplementary dredgings in 2007 and 2008 are also included.

Most of the remaining material is from five summer cruises along various parts of the northern and north-western coast of Norway, during the late 60 -ties and early 70 -ties. These cruises were a cooperation between marine biologists from the University of Bergen, and colleagues from the University of Tromsø (2 cruises with R/V 'Asterias'), and the Biological Station of the University of Trondheim (3 cruises with R/V 'Harry Borthen'). During these five years (1967 to 1971), the accumulated experience of the participants and the gradually increasing level of our ambitions resulted in more thorough sorting and work up of the material collected. Thus a lot of the smaller species ("microgastropods") were insufficiently sorted out in the 1967-, and partly also in the 1968-material. For the three most recent of the summer cruises, both empty shells and live caught specimens are included, but the two categories have been kept strictly apart. For the remaining material live caught specimens only (except for a few very rare species) are included.

Recently Per Wikander graciously donated parts of his extensive collection of small gastropods from the Skagerrak coast as far east as Kragerø ( $09^{\circ} 30^{\prime}$ E) collected during the 70-ties, and the Bodø region in Nordland county collected in 1976-77, in the main text referred to as 'the Wikander material from Skagerrak' and 'Nordland' respectively.

Material from 58 samples from the slope and shelf, supplemented by data from the deeper parts of the Norwegian Sea, the Norwegian Trench, the North Sea and some deep fjords, collected by Torleiv Brattegard and Jon-Arne Sneli during the 1980-ies during 30 'Norwegian Sea' cruises with R/V 'Håkon Mosby' have recently been made available through two work shops.This additional material has greatly enhanced the comprehensiveness of the work, permitting also the southern coast as well as the slope outside Norway to be included in a realistic way. The various cruises included are listed in Table 1.

Table I. The cruises included are, listed roughly from north to south:

\begin{tabular}{llllll} 
Year & Dates & Vessel & Approximate area & N limit & S limit \\
\hline 1967 & $05.07-12.07$ & R/V Asterias & East Finnmark & $70^{\circ} 13^{\prime}$ & $69^{\circ} 41^{\prime}$ \\
1968 & $17.06-22.06$ & R/V Asterias & Andfjorden & $69^{\circ} 25^{\prime}$ & $68^{\circ} 38^{\prime}$ \\
1971 & $28.06-07.07$ & R/V Harry Borthen & Nordland & $67^{\circ} 16^{\prime}$ & $65^{\circ} 29^{\prime}$ \\
1969 & $30.06-10.07$ & R/V Harry Borthen & Nord-Trøndelag & $65^{\circ} 14^{\prime}$ & $63^{\circ} 45^{\prime}$ \\
1970 & $29.06-10.07$ & R/V Harry Borthen & Møre og Romsdal & $63^{\circ} 26^{\prime}$ & $62^{\circ} 07$ \\
$1981-1987$ & & R/V Håkon Mosby & Slope and Norwegian Sea & & \\
\hline
\end{tabular}


During my long residence (from 1962 to 1990) at the Biological Station at Espegrend $\left(60^{\circ} 15^{\prime} \mathrm{N}\right)$, and the many student courses and excursions at the field station at Herdla $\left(60^{\circ} 35^{\prime} \mathrm{N}\right)$, thousands of gastropods were collected and identified, partly as accidental finds in dredge or trawl hauls, partly as components of quantitative samples for studies at specific localities or fjord systems. Thus all records from two extensive investigations of the Fensfjord system, performed in 1971-73 (together with Torleiv Brattegard) and 1988-89 (see Buhl-Mortensen \& Høisæter 1993) have been included, as have also the extensive material from time series investigations at Hillersholmen $\left(60^{\circ}\right.$ $17^{\prime} \mathrm{N}$ ) and Straume bridge (Knappensundet, $60^{\circ} 19^{\prime} \mathrm{N}$ ) in Raunefjorden (see Høisæter 1989). The gastropods from a study in 1992 of the epifauna on Laminaria hyperborea stipes outside Sotra $\left(60^{\circ} 10^{\prime} \mathrm{N}\right)$ are also included. Accidental finds of gastropods from the period from 1951 to 1973, including specimens donated by Anders Warén from his annual visits in the period 1969 to 1973 complete the material, and is collectively treated in the body of the report as material from the Espegrend area.

In two work shops, one at the biological field station of NTNU at Sletvik in outer Trondheims-fjorden, and a later one at the biological station of the University of Bergen at Espegrend, parts of the very extensive collections of Jon-Arne Sneli and Torleiv Brattegard from their joint cruises with R/V 'Håkon Mosby' during the 80-ties were sorted up and partly identified. Some material collected by Torleif Holthe, Jon-Arne Sneli and Per Pethon on several cruises with R/V 'Johan Ruud' from the shelf and slope outside northern Norway between 1979 and 1983, were also studied during the former work shop.The identifications at these work shops for which I am responsible, roughly 950 specimens of some 85 species, are included, and is the main justification for scetching the distribution in bathyal and abyssal waters outside the coast.

Regrettably the coverage of the coast is still far from complete. The western and northern coasts of Finnmark, northern Troms, the Lofoten area, Sogn og Fjordane county, and the coast south of Korsfjorden $\left(60^{\circ} 08^{\prime} \mathrm{N}\right)$ have not been sampled by me, and thus the remaining parts of the coast rely on literature and material supplied by Wikander.

What is to a large extent missing is a thorough scrutiny of accumulated museum material from Norwegian University museums. Especially Tromsø Museum has a large collection of molluscs collected by Tron Soot-Ryen during the 1920-ties and 30-ties along the coast of northern Norway from East Finnmark south to Bindalsfjorden, which so far has not been published. Unfortunately I have not had capacity to include this material in the present work.

During the work, it has become increasingly obvious that the classical alpha-taxonomy of some of the groups, as presented in Høisæter (1986), is no longer tenable, and thus a number of groups have been selected for a more thorough revision, based primarily on morphological, but also in a few cases, molecular characters, e.g. Anatoma, Raphitoma, Skeneidae, Pyramidellidae, Eulima, Vitreolina. Thus I have introduced a number of preliminary species names, like n. sp. A, B etc. for forms I regard as specifically distinct from the traditionally accepted species. In a few cases I have used 'aff.' when the similarity to a known species is regarded as helpful to provide an impression of an undescribed species. I have used 'cf.' in cases where the placement in an accepted species is not completely convincing but the material available is not sufficient for deciding one way or the other. Most of the material was identified to species soon after the various cruises and most of it has also been thoroughly restudied during the last year, thus all names follow CLEMAM. Information found in Høisæter (1986) is only incidentally repeated, and extensive listings of synonyms that might be found in CLEMAM or the articles of Warén or Bouchet $\&$ Warén listed above are not repeated.

The present study is composed of a SYSTEMATIC SYNOPSIS consistently following the system adopted by CLEMAM, and containing the 'valid' names, with authors, of all families genera and species reported from Norwegian waters. Geographically (see map, Fig. 1) the area covered includes the shelf and slope of the Norwegian coast from the Russian border in the northeast to the Swedish border in the southeast. In the north the Barents Sea south of $72^{\circ} \mathrm{N}$ is included, but none of the 'Norwegian' economic zone around Svalbard and Jan Mayen. In the south the North Sea and the western 'slope' of the Norwegian Trench have been excluded. On the continental slope I have included the area north of the Norwegian Trench, west to $0^{\circ} \mathrm{E}$. I have, somewhat arbitrarily, chosen to include the slope down to roughly $1200 \mathrm{~m}$, and mainly for this reason a number of abyssal species (species so far only reported from depths below $2000 \mathrm{~m}$ in the Norwegian Sea, or on the slope on the southern or western parts of the Norwegian Sea) have been included as doubtful species (with an asterisk), as experience has shown that they might occur also in negative temperatures on the Norwegian slope. Other species that for various reasons are not sufficiently well documented to be part of the Norwegian fauna, are also included as doubtful species. The main part of the text, COMMENTS ON EACH SPECIES, details the distribution along the coast of every species included, but also summarises any treatment of the species or group in question not available to me when the check-list (Høisæter 1986) was written. A Discussion summing up the important findings of the work are also included. REFERENCES and an INDEX OF SCIENTIFIC NAMES wrap up the report.

As is apparent from the above introduction, the distributional data may already be dated, as only a small part of the material has been collected during the last 20 years. A systematic followup investigation along the coast in the future could, however be a valuable test of whether the fauna has changed significantly 
during the last 30 years or so.

\section{Material and Methods}

As is fairly evident from the above, neither the coverage, nor the collecting efforts (or the sorting) have been homogeneous throughout the period this report covers. Thus a number of quantitative investigations in the area of the Biological
Station at Espegrend, are combined with data from a multitude of qualitative gears used throughout the summer cruises, and also during course work at the Herdla station and the extensive cruises with R/V 'Håkon Mosby'. These include triangular dredge, 'coral dredge', Agassiz trawls, epibenthic sledges of various designs, and finally a modified Rothlisberg and Pearcy (RP) sledge designed for catching hyperbenthic fauna, but also collecting a fair amount of epibenthos. The literature data has increased the heterogeneity further, and the results must be

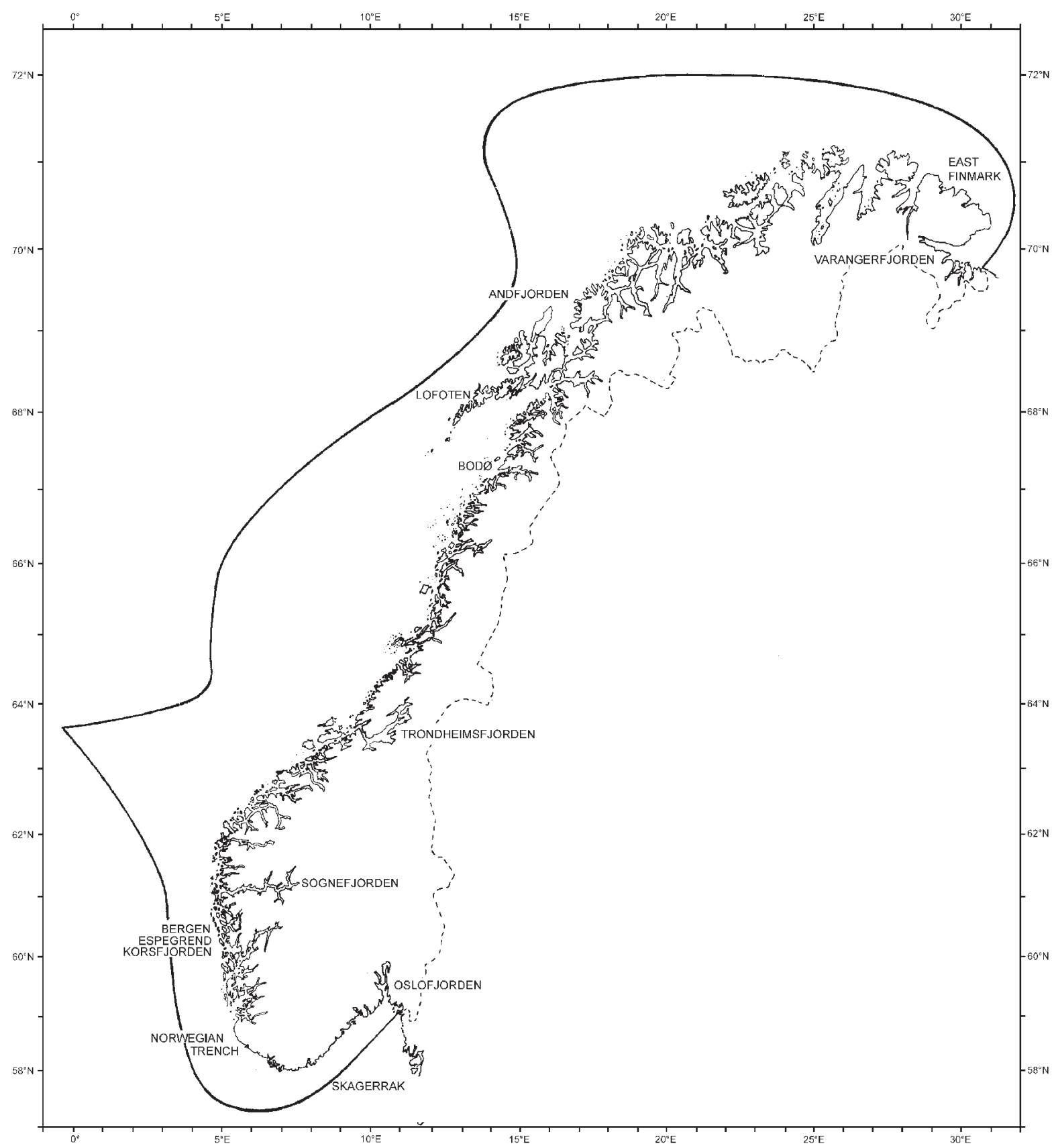

Figure I. Map of area covered with approximate limits for the ocean area included as 'Norwegian waters', and some frequently mentioned geographical names. 
regarded as a 'qualitative' first step. The material worked up at the work-shop at Sletvik, is deposited at Museum of Natural History and Archeology (NTNU). All the remaining material is deposited at the Zoological Museum of the University of Bergen.

An attempt has been made to use a consistent format throughout the text. Thus all names are according to Clemam. For each species, whenever the name is even slightly different from the one used in Høisæter (1986), that one is put in square brackets following the currently accepted name. Any nomenclatural or taxonomic comments are put first in the paragraph concerning the species in question, followed by the distribution in Norwegian waters based on literature data. Data on the distribution based on my own material is found at the end of each paragraph. In the alphabetic INDEX all genus and species name combinations in the main text (thus including all names used as 'valid' names in Høisæter 1986) are listed for easy localization of species with unfamiliar names.

\section{SysteMatic SynopsIS}

Species that for various reasons are not regarded as part of the Norwegian fauna are marked by an asterisk (*).

\section{DOCOGLOSSA}

\section{PATELLOIDEA}

PAtellidAe Rafinesque , 1815

Patella Linné, 1758

Patella ulyssiponensis (Gmelin, 1791)

Patella vulgata Linné, 1758

Ansates G.B. Sowerby II, 1840

Ansates pellucida (Linné, 1758)

\section{LOTTIOIDEA}

LOTTIIDAE J.E. Gray, 1840

Erginus Jeffreys, 1877

Erginus rubellus (O. Fabricius, 1780)

Tectura J.E. Gray, 1847

Tectura testudinalis (O.F. Müller, 1776)

Tectura virginea (O.F. Müller, 1776)

LEPETIDAE J.E. Gray, 1850

Lepeta J.E. Gray, 1847

Lepeta caeca (O.F. Müller, 1776)

Iothia J.E. Gray, 1850

Iothia fulva (O.F. Müller, 1776)
Iothia cf. fulva

Propilidium Forbes \& Hanley, 1849

Propilidium exiguum (W. Thompson, 1844)

\section{ARCHAEOGASTROPODA}

\section{VETIGASTROPODA}

\section{FISSURELLOIDEA}

FissuRellidAe Fleming, 1822

Emarginula Lamarck, 1801

Emarginula crassa J. Sowerby, 1813

Emarginula fissura (Linné, 1758)

Puncturella Lowe, 1827

Puncturella noachina (Linné, 1771)

Fissurisepta Seguenza, 1863

Fissurisepta granulosa Jeffreys, 1883

\section{SCISSURELLOIDEA}

ANATOMidAe McLean, 1989

Anatoma Woodward, 1859

Anatoma aspera (Philippi, 1844)

Anatoma crispata (Fleming, 1828)

Anatoma n. sp.

*Anatoma cf. umbilicata (Jeffreys, 1883)

\section{LEPETELLOIDEA}

LEPETELLIDAE Dall, 1882

Lepetella Verrill, 1880

Lepetella laterocompressa (de Rayneval \& Ponzi, 1854)

\section{TROCHOIDEA}

TROCHIDAE Rafinesque, 1815

TROCHINAE Rafinesque, 1815

Clelandella Winckworth, 1932

Clelandella miliaris (Brocchi, 1814)

Gibbula Risso, 1826

Gibbula cineraria (Linné, 1758)

Gibbula tumida (Montagu, 1803)

MARGaritinae Thiele, 1924

Margarites J.E. Gray, 1847

Margarites costalis (Gould, 1841)

Margarites helicina (Phipps, 1774) 
Margarites olivacea (Brown, 1827)

Margarites striata (Leach, 1819)

Solariellidae Powell, 1951

Solariella S. Wood, 1842

Solariella amabilis (Jeffreys, 1865)

Solariella obscura (Couthoy, 1838)

Solariella varicosa (Mighels \& Adams, 1842)

Calliostomatidae Thiele, 1924

Calliostoma Swainson, 1840

Calliostoma occidentale (Mighels \& Adams, 1842)

Calliostoma zizyphinus (Linné, 1758)

\section{SEGUENZOIDEA}

Chilodontidae Wenz, 1938

Danilia Brusina, 1865

Danilia tinei (Calcara, 1839)

\section{TURBINOIDEA}

TurbinIDAE Rafinesque, 1815

Moellerinae Hickman \& McLean, 1990

Moelleria Jeffreys, 1865

Moelleria costulata (Møller, 1842)

SkENEINAE Clarke, 1851

Skenea Fleming, 1825

Skenea areolata (G.O. Sars, 1878)

Skenea basistriata (Jeffreys, 1877)

Skenea ossiansarsi Warén, 1991

Skenea peterseni (Friele, 1877)

*Skenea profunda (Friele, 1879)

Skenea aff. proxima (Tryon 1888)

Skenea rugulosa (G.O. Sars, 1878)

Skenea trochoides (Friele, 1876)

*Skenea turgida (Odhner, 1912)

Skenea n.sp. A

Skenea n.sp. B

Anekes Bouchet \& Warén, 1979

*Anekes undulisculpta Bouchet \& Warén, 1979

Dikoleps Høisæter, 1968

Dikoleps nitens (Philippi, 1844)

Eudaronia Cotton, 1945

Eudaronia aperta (Sykes, 1925)

Lissotesta Iredale, 1915

Lissotesta turrita (Gaglini, 1987)
Palazzia Warén, 1991

Palazzia ausonia (Palazzi, 1988)

Retigyra Warén, 1989

Retigyra millipunctata (Friele, 1886)

Pendromidae Warén, 1991

Rugulina Palazzi, 1988

Rugulina fragilis (G.O. Sars, 1878)

ATAPHRIDAE Cossmann, 1915

Trochaclis Thiele, 1912

Trochaclis islandica Warén, 1989

\section{NERITIMORPHA}

\section{NERITOIDEA}

Neritidae Rafinesque, 1815

Theodoxus de Montfort, 1810

*Theodoxus fluviatilis (Linné, 1758

\section{APOGASTROPODA}

\section{CAENOGASTROPODA}

\section{CERITHIOIDEA}

CerithidDae Fleming, 1822

Bittium J.E. Gray, 1847

Bittium reticulatum (da Costa, 1778)

TURRITELLIDAE Lovén, 1847

Turritella Lamarck, 1799

Turritella communis Risso, 1826

\section{TRIPHOROIDEA}

TRIPHORIDAE J.E. Gray, 1847

Marshallora Bouchet, 1982

Marshallora adversa (Montagu, 1803)

Similiphora Bouchet, 1982

*Similiphora similior (Bouchet \& Guillemot, 1978)

Cerithiopsidae H. \& A. Adams, 1853

Cerithiopsis Forbes \& Hanley, 1851

Cerithiopsis tubercularis (Montagu, 1803)

Cerithiopsis barleei Jeffreys, 1867

Cerithiella Verrill, 1882

Cerithiella metula (Lovén, 1846) 
Krachia Baluk, 1975

Krachia cossmanni (Dautzenberg \& H. Fischer 1896)

Laeocochlis Dunker \& Metzger, 1874

Laeocochlis sinistratus (Nyst, 1835)

Eumetula Thiele, 1912

Eumetula arctica (Mørch, 1857)

Eumetula n.sp.

\section{JANTHINOIDEA}

ACLIDIDAE G.O. Sars, 1878

Aclis Lovén, 1846

Aclis ascaris (Turton, 1819)

Aclis minor (Brown, 1827)

Aclis sarsi Dautzenberg \& H. Fischer, 1912

Aclis walleri Jeffreys, 1867

EPITONIIDAE Berry, 1910

Epitonium Röding, 1798

Epitonium clathratulum (Kanmacher, 1798)

Epitonium clathrus (Linné, 1758)

Epitonium greenlandicum (Perry, 1811)

Epitonium trevelyanum (Johnston, 1841)

Epitonium turtonis (Turton, 1819)

Acirsa Mørch, 1857

Acirsa coarctata (Jeffreys, 1884)

Gregorioiscala Cossmann, 1912

Gregorioiscala sarsi (Kobelt, 1904)

\section{EULIMOIDEA}

Eulimidae H. \& A. Adams, 1853

Eulima Risso, 1826

Eulima bilineata Alder, 1848

Eulima n. sp.

Bathycrinicola Bouchet \& Warén, 1986

Bathycrinicola curta (Warén, 1972)

Crinolamia Bouchet \& Warén, 1979

Crinolamia dahli Bouchet \& Warén, 1979

Curveulima Laseron, 1955

Curveulima macrophthalmica (Warén, 1972)

Enteroxenos Bonnevie, 1902

Enteroxenos oestergreni Bonnevie, 1902
Entocolax Voigt, 1881

*Entocolax sp.

Haliella Monterosato, 1878

Haliella stenostoma (Jeffreys, 1858)

Halielloides Bouchet \& Warén, 1986

Halielloides nitidus (Verrill, 1884)

Hemiaclis G.O. Sars, 1878

Hemiaclis ventrosus (Friele, 1876)

Melanella Bowdich, 1822

Melanella alba (da Costa, 1778)

Melanella frielei (Jordan, 1895)

Melanella laurae (Friele, 1886)

Melanella lubrica (Monterosato, 1890)

Melanella monterosatoi (Monterosato, 1890)

Melanella orphanensis Clarke, 1974

Melanella cf. polita (Linné, 1758)

Melanella turrita Bouchet \& Warén, 1986

Pelseneeria Köhler \& Vaney, 1908

Pelseneeria stylifera (Turton, 1825)

Vitreolina Monterosato, 1884

Vitreolina n. spp.

\section{LITTORINOIDEA}

LITTORINIDAE J.E. Gray, 1840

LitTORININAE J.E. Gray, 1840

Littorina Férussac, 1822

Littorina arcana Hannaford Ellis, 1978

Littorina compressa Jeffreys, 1865

Littorina fabalis (Turton, 1825)

Littorina littorea (Linné, 1758)

Littorina obtusata (Linné, 1758)

Littorina saxatilis (Olivi, 1792)

Melarhaphe Menke, 1828

Melarhaphe neritoides (Linné, 1758)

LACUNINAE J.E. Gray, 1857

Lacuna Turton, 1827

Lacuna crassior (Montagu, 1803)

Lacuna pallidula (da Costa, 1778)

Lacuna parva (da Costa, 1778)

Lacuna vincta (Montagu, 1803)

SkeneopsidAe Iredale, 1915

Skeneopsis Iredale, 1915

Skeneopsis planorbis (0. Fabricius, 1780) 


\section{RISSOOIDEA}

RISSOIDAE J.E. Gray, 1847

Rissoa Desmarest, 1814

Rissoa lilacina Récluz, 1843

?Rissoa rufilabrum (Alder, 1844)

?Rissoa porifera Lovén, 1846

Rissoa membranacea (J. Adams, 1800)

Rissoa parva (da Costa, 1778)

Pusillina Monterosato, 1884

Pusillina inconspicua (Alder, 1844)

Pusillina sarsii (Lovén, 1846)

Alvania Risso, 1826

Alvania beani (Hanley in Thorpe, 1844)

Alvania cimicoides (Forbes, 1844)

Alvania incognita Warén, 1996

Alvania jeffreysi (Waller, 1864)

Alvania moerchi (Collin, 1886)

Alvania aff. moerchi

Alvania pseudosyngenes (Warén, 1973)

Alvania punctura (Montagu, 1803)

Alvania subsoluta (Aradas, 1847)

Alvania cf. scrobiculata (Møller, 1842)

Alvania testae (Aradas \& Maggiore, 1844)

Alvania verrilli (Friele, 1886)

Alvania wyvillethomsoni (Friele, 1877)

Alvania zetlandica (Montagu, 1815)

Alvania n.sp.

Boreocingula Golikov \& Kussakin, 1974

Boreocingula castanea (Møller, 1842)

Cingula Fleming, 1818

Cingula trifasciata (J. Adams, 1800)

Crisilla Monterosato, 1917

Crisilla semistriata (Montagu, 1808)

Frigidoalvania Warén, 1974

Frigidoalvania janmayeni (Friele, 1878)

Manzonia Brusina, 1870

*Manzonia crassa (Kanmacher, 1798)

Obtusella Cossmann, 1921

Obtusella intersecta (S.V. Wood, 1841)

Obtusella tumidula (G.O. Sars, 1878)

Onoba H. \& A. Adams, 1854

Onoba aculeus (Gould, 1841)

Onoba islandica (Friele, 1886)

Onoba semicostata (Montagu, 1803)
Onoba cf. improcera Warén 1996

Pseudosetia Monterosato, 1884

*Pseudosetia semipellucida (Friele, 1879)

Pseudosetia turgida (Jeffreys, 1870)

CAECIDAE J.E. Gray, 1850

Caecum Fleming, 1813

Caecum glabrum (Montagu, 1803)

ELACHISINIDAE Ponder, 1985

Elachisina Dall, 1918

*Elachisina globuloides (Warén, 1972)

HydroBIIDAE Troschel, 1857

Hydrobia Hartmann, 1821

Hydrobia neglecta Muus, 1963

Hydrobia ulvae (Pennant, 1777)

Potamopyrgus Stimpson, 1865

Potamopyrgus antipodarum (Gray, 1843)

Ventrosia Radoman, 1977

Ventrosia ventrosa (Montagu, 1803)

IRAVADIIDAE Thiele, 1928

Ceratia $\mathrm{H} \&$ A Adams, 1852

*Ceratia proxima (Forbes \& Hanley, 1850)

Hyala H. \& A. Adams, 1852

Hyala vitrea (Montagu, 1803)

TORNIDAE Sacco, 1896

Circulus Jeffreys, 1865

Circulus sarsi (Bush, 1898)

\section{STROMBOIDEA}

AporRhaidae J.E. Gray, 1850

Aporrhais da Costa, 1778

Aporrhais pespelecani (Linné, 1758)

Aporrhais serresianus (Michaud, 1828)

\section{VANIKOROIDEA}

Haloceratidae Warén \& Bouchet, 1991

Haloceras Dall, 1889

*Haloceras aff. laxa (Jeffreys, 1885)

\section{CALYPTRAEOIDEA}

CAlyptraeidae Lamarck, 1809

Crepidula Lamarck, 1809

Crepidula fornicata (Linné, 1758) 


\section{CAPULOIDEA}

CAPULIDAE Fleming, 1822

Capulus Montfort, 1810

Capulus ungaricus (Linné, 1758)

Torellia Jeffreys, 1867 ex Lovén MS

Torellia delicata (Philippi, 1844)

Trichotropis Broderip \& G.B. Sowerby I, 1829

Trichotropis borealis Broderip \& G.B. Sowerby I, 1829

Trichotropis conicus Møller, 1842

Trichotropis cf. borealis

Trichotropis n. sp.

\section{VELUTINOIDEA}

VelutinidAe J.E. Gray, 1842

Velutininae J.E. Gray, 1840

Velutina Fleming, 1821

Velutina lanigera Møller, 1842

Velutina plicatilis (O.F. Müller, 1776)

Velutina schneideri Friele, 1886

Velutina undata J. Smith, 1839

Velutina velutina (O.F. Müller, 1776)

Onchidiopsis Bergh, 1853

Onchidiopsis glacialis (M. Sars, 1851)

Piliscus Lovén, 1859

Piliscus radiatus (M. Sars, 1851)

LAMELLARIINAE d'Orbigny, 1841

Lamellaria Montagu, 1815

Lamellaria latens (O.F. Müller, 1776)

Lamellaria perspicua (Linné, 1758)

Calyptoconcha Bouchet \& Warén, 1993

Calyptoconcha cf. pellucida (Verrill, 1880)

Marseniella Bergh, 1886

Marseniella borealis Bergh, 1886

Marsenina J.E. Gray, 1850

Marsenina glabra (Couthouy, 1839)

TRIVIIDAE Troschel, 1863

Trivinae Troschel, 1863

Trivia Broderip, 1837

Trivia arctica (Pulteney, 1799)

ERATOINAE Gill, 1871

Erato Risso, 1826
Erato voluta (Montagu, 1803)

\section{NATICOIDEA}

NATICIDAE Forbes, 1838

Cryptonatica Dall, 1892

Cryptonatica affinis (Gmelin, 1791)

Cryptonatica bathybii (Friele, 1879)

Euspira (Agassiz in J. Sowerby, 1837)

Euspira montagui (Forbes, 1838)

Euspira pallida (Broderip \& G.B. Sowerby I, 1829)

Euspira pulchella (Risso, 1826)

Euspira n.sp.

Amauropsis Mørch, 1857

Amauropsis islandica (Gmelin, 1791)

Bulbus Brown, 1839

Bulbus smithi (Brown, 1839)

Pseudopolinices Golikov \& Sirenko, 1983

Pseudopolinices nanus (Møller, 1842)

\section{MURICOIDEA}

MURICIDAE Rafinesque, 1815

OCEneBrinae Cossmann, 1903

Nucella Röding, 1798

Nucella lapillus (Linné, 1758)

Trophoninae Cossman, 1903

Trophonopsis Bucquoy, Dautzenberg \& Dollfus, 1882 Trophonopsis barvicensis (Johnston, 1825)

Boreotrophon P. Fischer, 1884

Boreotrophon clathratus (Linné, 1767)

Boreotrophon clavatus (G.O. Sars, 1878)

Boreotrophon truncatus (Strøm, 1768)

Scabrotrophon McLean, 1996

*Scabrotrophon fabricii (Møller, 1842)

TurbinelLIDAE Swainson, 1835

Metzgeria Norman, 1879

Metzgeria alba (Wyville-Thomson, 1873)

Volutomitridae J.E. Gray, 1854

Volutomitra H. \& A. Adams, 1853

Volutomitra groenlandica (Møller, 1842)

\section{BUCCINOIDEA}

BucCINIDAE Rafinesque, 1815 
Buccinum Linné, 1758

Buccinum cyaneum Bruguière, 1792

Buccinum undulatum Møller, 1842

Buccinum finmarkianum Verkrüzen, 1875

Buccinum humphreysianum Bennett, 1824

Buccinum hydrophanum Hancock, 1846

Buccinum kjennerudae Bouchet \& Warén, 1985

Buccinum nivale Friele, 1882

Buccinum oblitum Sykes, 1911

*Buccinum scalariforme Møller, 1842

Buccinum tumidulum G.O. Sars, 1878

Buccinum undatum Linné, 1758

Beringius Dall, 1887

Beringius turtoni (Bean, 1834)

Colus Röding, 1798

Colus gracilis (da Costa, 1778)

Colus holboelli (Møller, 1842)

Colus islandicus (Mohr, 1786)

Colus jeffreysianus (P. Fischer, 1868)

Colus latericeus (Møller, 1842)

Colus sabini (J.E. Gray, 1824)

Colus turgidulus (Friele, 1877)

Colus verkruezeni (Kobelt, 1876)

Liomesus Stimpson, 1865

Liomesus ovum (Turton, 1825)

Mohnia Friele, 1879

*Mohnia danielsseni (Friele, 1879)

Mohnia glypta (Verrill, 1882)

Mohnia mohni (Friele, 1877)

Neptunea Röding, 1798

*Neptunea antiqua (Linné, 1758)

Neptunea despecta (Linné, 1758)

Troschelia Mørch, 1876

Troschelia berniciensis (King, 1846)

Turrisipho Dautzenberg \& H. Fischer, 1912

Turrisipho dalli (Friele in Tryon, 1881)

Turrisipho fenestratus (Turton, 1834)

Turrisipho lachesis (Mørch, 1869)

Turrisipho moebii (Dunker \& Metzger, 1874)

Turrisipho voeringi (Bouchet \& Warén, 1985)

Volutopsius Mørch, 1857

Volutopsius norwegicus (Gmelin, 1791)

NASSARIIDAE Iredale, 1916

Nassarius Duméril, 1806

Nassarius incrassatus (Strøm, 1868)
Nassarius pygmaeus (Lamarck, 1822)

Nassarius nitidus (Jeffreys, 1867)

Columbellidae Swainson, 1840

Amphissa H. \& A. Adams, 1853

Amphissa acutecostata (Philippi, 1844)

Mitrella Risso, 1826

Mitrella rosacea (Gould, 1840)

\section{CANCELLARIOIDEA}

Cancellariidae J.E. Gray, 1853

Admete Møller, 1842

Admete contabulata Friele, 1879

Admete viridula (Fabricius, 1780)

Admete n.sp.

Iphinopsis Dall, 1924

Iphinopsis inflata (Friele, 1879)

\section{CONOIDEA}

Conidae Fleming, 1822

Borsoninae A. Bellardi, 1875 (??)

Typhlomangelia G.O. Sars, 1878

Typhlomangelia nivalis (Lovén, 1846)

Oenopotinae Bogdanov, 1987

Oenopota Mørch, 1852

Oenopota assimilis (G.O. Sars, 1878)

Oenopota bergensis (Friele, 1886)

Oenopota elegans (Møller, 1842)

Oenopota exarata (Møller, 1842)

Oenopota harpularia (Couthouy, 1839)

Oenopota impressa (Mørch, 1869)

Oenopota nobilis (sensu Stokland, 1981)

*Oenopota ovalis (Friele, 1877)

Oenopota pyramidalis (Strøm, 1768)

Oenopota tenuicostata (G.O. Sars, 1878)

Oenopota trevelliana (Turton, 1834)

Oenopota turricula (Montagu, 1803)

Oenopota violacea (Mighels \& Adams, 1842)

Mangelinae P. Fischer, 1883

Bela J.E. Gray, 1847

Bela brachystoma (Philippi, 1844)

Bela costulata (Risso, 1826)

Bela nebula (Montagu, 1803)

Bela powisiana (Dautzenberg, 1887)

Mangelia Risso, 1826

Mangelia attenuata (Montagu, 1803)

Mangelia coarctata (Forbes, 1840) 
RAPHITOMINAE A. Bellardi, 1875

Raphitoma L. Bellardi, 1848

Raphitoma aequalis (Jeffreys, 1867)

Raphitoma concinna (Scacchi, 1836)

Raphitoma echinata (Brocchi, 1814)

Raphitoma linearis (Montagu, 1803)

Raphitoma purpurea (Montagu, 1803)

Raphitoma n. sp.

Nepotilla Hedley, 1918

Nepotilla amoena (G.O. Sars, 1878)

Teretia Norman, 1888

Teretia teres (Reeve, 1844)

Pleurotomella Verrill, 1872

Pleurotomella packardi Verrill, 1872

Thesbia Jeffreys, 1867

Thesbia nana (Lovén, 1846)

Taranis Jeffreys, 1870

Taranis borealis Bouchet \& Warén, 1980

Taranis moerchi (Malm, 1863)

DRILLIIDAE Olsson, 1964

Spirotropis G.O. Sars, 1878

Spirotropis modiolus (de Cristofori \& Jan, 1832)

Turridae H. \& A. Adams, 1853

Haedropleura Bucquoy, Dautzenberg \& Dollfus, 1883

*Haedropleura septangularis (Montagu, 1803)

\section{HETEROBRANCHIA}

\section{HETEROSTROPHA}

\section{MATHILDOIDEA}

MathiLdidAe Dall, 1889

Turritellopsis G.O. Sars, 1878

Turritellopsis stimpsoni Dall, 1919

\section{RISSOELLOIDEA}

RisSoelLIDAE M.E. Gray, 1850

Rissoella J.E. Gray, 1847

Rissoella diaphana (Alder, 1848)

Rissoella globularis (Forbes \& Hanley, 1853)

*Rissoella opalina (Jeffreys, 1848)

\section{OMALOGYROIDEA}

OMalogyridae G.O. Sars, 1878

Omalogyra Jeffreys, 1860

Omalogyra atomus (Philippi, 1841)

Ammonicera Vayssière, 1893

Ammonicera rota (Forbes \& Hanley, 1850)

\section{VALVATOIDEA}

Xylodisculidae Warén, 1992

Xylodiscula Marshall, 1988

Xylodiscula planata Høisæter \& Johannessen, 2001

\section{PYRAMIDELLOIDEA}

Pyramidellidae J.E. Gray, 1840

Aartsenia Warén, 1991

*Aartsenia candida (Møller, 1842)

Chrysallida Carpenter, 1856

Chrysallida bjoernssoni Warén, 1991

Chrysallida brattstroemi Warén, 1991

Chrysallida eximia (Jeffreys, 1849)

Chrysallida hoeisaeteri Warén, 1991

Chrysallida indistincta (Montagu, 1808)

Chrysallida interstincta (J. Adams, 1797)

Chrysallida nivosa (Montagu, 1803)

Chrysallida pellucida (Dillwyn, 1817)

*Chrysallida sarsi (Nordsick, 1972)

Chrysallida sublustris (Friele, 1886)

*Chrysallida truncatula (Jeffreys, 1850)

Eulimella Forbes \& MacAndrew, 1846

Eulimella acicula (Philippi, 1836)

Eulimella ataktos Warén, 1991

Eulimella 'compactilis' (sensu G.O. Sars, 1878)

Eulimella scillae (Scacchi, 1835)

Eulimella ventricosa (Forbes, 1844)

Eulimella n. sp.

Odostomia Fleming, 1813

Odostomia acuta Jeffreys, 1848

*Odostomia cf. angusta (Jeffreys, 1867)

Odostomia carrozzai (van Aartsen, 1987)

Odostomia conoidea (Brocchi, 1814)

Odostomia conspicua Alder, 1850

Odostomia eulimoides (Hanley, 1844)

Odostomia lukisi Jeffreys, 1859

*Odostomia cf. plicata (Montagu, 1803)

Odostomia scalaris MacGillivray, 1843

Odostomia striolata Forbes \& Hanley, 1850

Odostomia cf. turgida G.O. Sars, 1878 
Odostomia turrita Hanley, 1844

Odostomia unidentata (Montagu, 1803)

*Odostomia sp. A

\section{Liostomia G.O. Sars, 1878}

Liostomia afzelii Warén, 1991

Liostomia clavula (Lovén, 1846)

Liostomia eburnea (Stimpson, 1851)

Liostomia hansgei Warén, 1991

Ondina de Folin, 1870

*Ondina coarctata (G.O. Sars, 1878)

Ondina diaphana (Jeffreys, 1848)

Ondina divisa (J. Adams, 1797)

Ondina normani (Friele, 1886)

Ondina obliqua (Alder, 1844)

*Ondina perezi (Dautzenberg \& Fischer, 1925)

Ondina cf. warreni (Thompson, 1845)

Rissopsetia Dell, 1956

*Rissopsetia cf. islandica Warén, 1989

Turbonilla Risso, 1826

Turbonilla crenata (Brown, 1827)

*Turbonilla lactea (Linné, 1767)

Turbonilla cf. pusilla (Philippi, 1844)

Turbonilla rufa (Philippi, 1836)

Turbonilla rufescens (Forbes, 1846)

Bacteridium Thiele, 1931

Bacteridium cf. carinatum (de Folin, 1870)

MurChisonellidae Casey, 1904

Ebala J.E. Gray, 1847

Ebala nitidissima (Montagu, 1803)

\section{UNASSIGNED SUPERFAMILY}

Cimidae Warén, 1993

Cima Chaster, 1896

Cima cuticulata Warén, 1993

Cima cf. cuticulata

Cima inconspicua Warén, 1993

Cima minima (Jeffreys, 1858)

Graphis Jeffreys, 1867

Graphis albida (Kanmacher, 1798)

TJaernoeidDae Warén, 1991

Tjaernoeia Warén \& Bouchet, 1988

Tjaernoeia exquisita (Jeffreys, 1883)

Tjaernoeia n.sp.

\section{OPISTHOBRANCHIA}

\section{CEPHALASPIDEA}

ACteOnidae d'Orbigny, 1835

Acteon Montfort, 1810

Acteon tornatilis (Linné, 1758)

DiAPHANIDAE Odhner, 1914

Diaphana T. Brown, 1827

Diaphana globosa (Lovén, 1846)

Diaphana hiemalis (Couthouy, 1839)

*Diaphana lactea (Jeffreys, 1877)

Diaphana minuta Brown, 1827

Colobocephalus M. Sars, 1870

Colobocephalus costellatus M. Sars, 1870

Colpodaspis M. Sars, 1870

Colpodaspis pusilla M. Sars, 1870

Rhinodiaphana Lemche, 1967

Rhinodiaphana ventricosa (Jeffreys, 1865)

Toledonia Dall, 1902

Toledonia limnaeoides (Odhner, 1913)

Retusidae Thiele, 1931

Retusa T. Brown, 1827

Retusa obtusa (Montagu, 1803)

Retusa truncatula (Bruguière, 1792)

Cylichnina Monterosato, 1884

Cylichnina umbilicata (Montagu, 1803)

Pyrunculus Pilsbry, 1894

Pyrunculus ovatus (Jeffreys, 1871)

Volvulella Newton, 1891

Volvulella acuminata (Bruguière, 1792

HaminOeIDAE Pilsbry, 1895

Cylichnium Dall, 1908

*Cylichnium africanum (Locard, 1897)

Philinidae J.E. Gray, 1850

Johania Monterosato, 1884

Johania cf. retifera (Forbes, 1844)

Laona A. Adams, 1865

Laona finmarchica (M. Sars, 1858)

Laona flexuosa (M. Sars, 1870)

Laona pruinosa (W. Clark, 1827) 
Philine Ascanius, 1772

Philine angulata Jeffreys, 1867

Philine aperta (Linné, 1767)

Philine catena (Montagu, 1803)

Philine denticulata (J. Adams, 1800)

Philine infortunata Pilsbry, 1895

Philine lima (Brown, 1827)

Philine punctata (J. Adams, 1800)

Philine quadrata (S. Wood, 1839)

Philine scabra (O.F. Müller, 1784)

Cylichnidae H. \& A. Adams, 1854

Cylichna Lovén, 1846

Cylichna alba (Brown, 1827)

Cylichna cylindracea (Pennant, 1777)

Cylichna lemchei Bouchet \& Warén, 1979

Cylichna occulta (Mighels \& Adams, 1842)

Roxania J.E. Gray, 1847

Roxania utriculus (Brocchi, 1814)

Scaphander Montfort, 1810

Scaphander lignarius (Linné, 1758)

Scaphander punctostriatus (Mighels \& Adams, 1842)

\section{ANASPIDEA}

AKeridAe Pilsbry, 1893

Akera O.F. Müller, 1776

Akera bullata O.F. Müller, 1776

APLYSIIDAE Lamarck, 1809

Aplysia Linné, 1767

Aplysia punctata Cuvier, 1803

\section{COMMENTS ON EACH SPECIES}

Patella ulyssiponensis (Gmelin, 1791) [= Patella aspera Röding, 1798] - Long known as Patella aspera, the older name $P$. ulyssiponensis was resurrected by Christiaens (1973). More recently $P$. aspera has been accepted as a subspecies found on the Macaronesian islands, and later elevated to full specific status by Weber \& Hawkins (2005) based on allozyme data. Sá-Pinto et al. (2005) based on mitochondrial DNA sequence data, supported this conclusion, but did not explicitely confirm the specific status of both clades. The European mainland populations belong to $P$. ulyssiponensis, and $P$. aspera can no longer be regarded as a synonym. A littoral species in Norway only known from exposed rocky shores in the south- western part of the country. Reported for the first time by Kolstad (1959), who found it from the island Rott outside Stavanger $\left(58^{\circ} 55^{\prime} \mathrm{N}\right)$ and north to the northern end of Øygarden northwest of Bergen $\left(60^{\circ}\right.$ 40’ N). Brattegard (in Høisæter et al. 1997a) extended the distribution marginally, south to his sector 6 , from $58^{\circ} 40^{\prime} \mathrm{N}$ and southwards, and north to his sector 9, extending from $60^{\circ} 51^{\prime} \mathrm{N}$ and northwards. Conchologically it is very similar to Patella vulgata and may have been confused with that species by earlier authors. In my material three specimens from the outer side of a wave exposed islet outside Sotra at $60^{\circ} 10^{\prime} \mathrm{N}$. Not in my material from north of Stadt, but the wave exposed intertidal was not visited during the summer cruises.

Patella vulgata Linné, 1758 - This well known and conspicuous littoral species is reported by G.O. Sars (1878) from Oslofjorden north to Lofoten. While G.O. Sars did not find the species north of Lofoten, Schneider $(1886,1897)$ reported it from Torsvåg on Vanna in Troms county $\left(70^{\circ} 15^{\prime} \mathrm{N}, 19^{\circ} 30^{\prime} \mathrm{E}\right)$. Dons $(1933,1949)$ found it on Gåsøy just north of Ingøya in western Finnmark ( $71^{\circ} 05^{\prime} \mathrm{N}, 24^{\circ} 10^{\prime} \mathrm{E}$ ), but not further east although he looked for it in several likely places. All his records from northern Norway are from the outer coast, but Soot-Ryen (1951) found thriving colonies inside several fjords in the northern part of Nordland county. Vader $(1972,1975)$ found it at Havøysund $\left(71^{\circ} \mathrm{N}, 24^{\circ} 40^{\circ} \mathrm{E}\right)$ and Honningsvåg $\left(71^{\circ} \mathrm{N}, 26^{\circ} \mathrm{E}\right)$, places where Dons had looked for it in vain. Honningsvåg thus seems to be the easternmost reported locality for this species on the Norwegian coast. In sum, these reports may be taken as evidence that the species has expanded its distribution since the 1880 -ies. Indirect evidence presented by Vader (1975) from Skjervøy in northern Troms county, indicates that the species has expanded its distribution since Don's visit in 1933. At the southern end of its distribution in Scandinavia, it seems to have declined significantly since around 1985 (Næs et al. 1998), and according to Hansson (2007) it has completely disappeared from the western coast of Sweden. Wikander (in Hansson 2007) reports its complete disappearance from the Norwegian Skagerrak coast east of Lindesnes since 2002. Still present in reasonable numbers west of Lindesnes though. Wikander (in litt. 2008) has expanded on this information by stating that while the population west of Lindesnes seems to consist of large and old specimens only, scattered juveniles seem to have reappeared in the vicinity of Grimstad in the last few years. In my material only a few scattered specimens, the northernmost from the bottom of Austerfjorden on Hinnøya, $68^{\circ} 38^{\prime}$ N. Like 
other species of rocky shore gastropods, not particularly looked for during the summer cruises.

Ansates pellucida (Linné, 1758) - Recently this very characteristic little limpet, usually confined to the lamina and stipes of Laminaria hyperborea, has been retransferred to the genus Patella based on both morphological and molecular genetic data (Ridgway et al. 1998, Koufopanou et al. 1999). This conclusion has been accepted by Nakano \& Ozawa (2004), but not by CLEMAM, and further molecular genetic work by Sá-Pinto et al. (2005) clearly indicates that this species is more distantly related to any of the northeast Atlantic rocky shore species than any two of these are to each other. In combination with the characteristic shell morphology and deviating habitat, this argues strongly for keeping the species in its own genus. The species is known from the whole coast from Oslofjorden (G.O. Sars 1878), the Skagerrak coast from Fevik and Grimstad (Wikander 1989, 1990), and from Kvitsøy and northwards (Dons 1949), including East Finnmark (Schneider 1897), but is not yet reported from the northern coast of the Varanger peninsula. In my material only scattered shells, except for the dedicated investigation of epifauna on Laminaria hyperborea stipes at Lyroddane $\left(60^{\circ} 10^{\prime} \mathrm{N}\right)$ in 1992 , where numerous specimens were collected. The northernmost of my samples from Andfjorden, $69^{\circ} 17^{\prime} \mathrm{N}$.

Erginus rubellus (O. Fabricius, 1780) [= Acmaea rubella (Fabricius, 1780)] - This species belong to the only genus of brooders within the Docoglossa, and has an isolated, basal systematic position within the family Lottiidae (Nakano \& Ozawa 2007). According to the key in Odhner (1912) the species is mainly distinguished morphologically from $T$. virginea by a taller shell and by a uniform reddish, brownish or yellowish shell colour, without radiating sculpture or radiating coloured stripes. It is a decidedly northern species, reported from the Norwegian coast as isolated finds south to $69^{\circ} \mathrm{N}$ (outside Kastneshamn in Dyrøysundet, $20 \mathrm{~m}$ ) but also recorded around $65^{\circ}$ 41 ' $\mathrm{N}$ on the shelf at $400-500 \mathrm{~m}$ (both records from Dautzenberg \& Fischer 1912). Friele \& Grieg (1901) found a single shell at $550 \mathrm{~m}$ outside Andøya, around $69^{\circ}$ N, and G.O. Sars (1878) attributes a record from Vadsø to Verkrüzen. Schneider (1886) reports it as occasional from Lithothamnion and especially on old shells of Modiolus modiolus at 40-60 m depth in the sounds around Tromsø, where also M. Sars found it. Not in my material.
Tectura virginea (O.F. Müller, 1776) [= Acmaea virginea (Müller, 1776)] - Recent molecular genetic work (Nakano \& Ozawa 2004, 2007) indicates that $T$. virginea is the sole representative of its genus, and that species earlier classified as Tectura, in particular T. testudinalis, should be transferred to other genera. T. virginea, has been recorded as common in the shallow sublittoral from the whole coast, but is more common in the south than in the extreme north (it is not known from the coast of North America). Reported from 14 localities on the Norwegian Skagerrak coast by Wikander. In my material almost 3500 specimens from the Espegrend area, and a further 250 from the summer cruises. Living specimens always from moderate depths (1 to $40 \mathrm{~m}$ ), on shells and other hard substrates not covered with silt. In my material high numbers from each of the sectors, most numerous in the Espegrend area where quantitative samples were taken from several shallow water current swept localities. High numbers were also secured from the fjords branching off from the south end of Andfjorden, around 68 40' $-69^{\circ} \mathrm{N}$, where shallow water, rocky bottoms densely covered with red algae are dominating. The morphology of specimens from the northern stations tend to be different from those from the Espegrend area, as the fully grown specimens are high, cone shaped, and thick shelled, completely opaque whitish (but sometimes with remnants of reddish radiating rays), while those from the Espegrend area are flattish, thin shelled and translucent, with characteristic pink rays radiating from the apex towards the edge of the shells (a colour pattern that tends to fade away and change when being kept for a long time in ethanol). This difference was noted also by Schneider (1886).

Tectura testudinalis (O.F. Müller, 1776) [= Acmaea testudinalis (Müller, 1776)] - The generic placement of this species is disputed. Most experts agree that it is sufficiently distinct from $T$. virginea to warrant another genus name. Thus Moskalev created for it the monotypic genus Testudinalia in 1996. Clemam recently referred the species to Testudinalia, presumably as a subgenus of Tectura. According to Nakano \& Ozawa $(2004,2007)$ there is ample molecular genetic evidence for including the species in the (paraphyletic) genus Lottia, and it will certainly be removed from Tectura in the future. This basically Arctic, circumpolar species is common in the rocky intertidal around the coast. Reported from 12 localities on the Norwegian Skagerrak coast by Wikander (1989, 1990). In my material most frequently (17 localities) encountered in East Finnmark, but present as scattered shells throughout the investigated area. 
In the Espegrend area in addition to the usual habitat in the intertidal, juveniles have been found in small numbers (altogether some 50 specimens) together with much higher numbers of $T$. virginea in the upper sublittoral, 3 to $15 \mathrm{~m}$ ). The species also seems to be popular as a food item for the flatfish Microstomus kitt. In eight stomachs from this species it dominated the identifiable food items, eight fairly large specimens of $T$. testudinalis versus four of $T$. virginea and only single individuals of each of 11 other species of gastropods.

Lepeta caeca (O.F. Müller, 1776) - This northern species is known from all around our coasts (e.g. Odhner 1912), although probably less common south of Trondheims-fjorden. Reported by Jeffreys (1870) from Oslofjorden, and G.O. Sars (1878) reported it to be not uncommon along the whole coast, but Wikander (1989) found only a single specimen (just outside Songvår lighthouse, Søgne, $58^{\circ} 01^{\prime} \mathrm{N}, 72$ $\mathrm{m}$, mixed bottom) in his extensive investigations of the Skagerrak coast. Grieg (1914) reported it from Hardangerfjorden, but remarked that it is rather infrequent in the Bergen area. It is usually found on hard objects on or near silty or clayey bottoms from 20 to $200 \mathrm{~m}$. In my material some 350 specimens, rather evenly distributed from around $64^{\circ} \mathrm{N}$ and northwards. The highest number encountered in a single sample was 96 specimens in a dredge haul in Stokken sound (64 $04^{\prime}$ N, 120-60 m, stones, gravel and slag). Another very rich sample was one from Holmengråfjorden in Sør-Varanger (69 $51^{\prime}$ N, 60-65 $\mathrm{m}$, sand, mud and old shells) containing 36 specimens. South of $63^{\circ} \mathrm{N}$ only scattered records, three specimens around $62^{\circ} 20^{\prime} \mathrm{N}$ and 14 in the Espegrend area.

Iothia fulva (O.F. Müller, 1776) - Another species known from the whole coast from 10 to $400 \mathrm{~m}$ (e.g. Odhner 1912), from mixed bottom with shells and pebbles. Wikander $(1989,1990)$ found it at seven localities on the Skagerrak coast from 20 to $155 \mathrm{~m}$. This species is not known from Arctic waters outside Norway, and is more evenly distributed along the coast, with proportionally higher numbers in the southern part of its distribution. In my material from East Finnmark only a few shells. Some more, but still only empty shells from the Andfjord area. The northernmost specimens were two from a station SW of Bodø $\left(67^{\circ} 16^{\prime} \mathrm{N}, 13 \mathrm{~m}\right.$, coarse shell gravel, shells and Laminaria). Otherwise from one to five specimens in each of from five to 10 samples in the remaining sectors southwards, usually shells much more numerous in each sample.
*Iothia cf. fulva - A single specimen from $1252 \mathrm{~m}$ outside Brekke in Sognefjorden $\left(62^{\circ} 03^{\prime} \mathrm{N}\right)$ roughly fit the morphology of Iothia fulva, but with certain differences. It is small $(2.6 \mathrm{~mm}$ long, $1.55 \mathrm{~mm}$ wide and 1.0 $\mathrm{mm}$ high) with parallell sides. Completely transparent, glassy clear, no shell pigment. Apex close to the front end and with shell curving gradually behind the apex. Regular, linear rows of nodules or minute spines radiating down from apex. Iothia fulva of the same size is yellow to orange, opaque, flatter with a more oval outline. In addition the soft parts are less bulky in Iothia fulva. The radiating rows of small nodules are rather variable in juveniles of Iothia fulva, being both more and less dominating than in Iothia cf. fulva. Finally, Iothia fulva is basically a species to be found on rather coarse bottom at moderate depths, not previously recorded from 1200 to $1300 \mathrm{~m}$ in Norwegian fjords. It might be an aberrant specimen of Iothia fulva, but lack of material does not allow a final verdict.

Propilidium exiguum (W. Thompson, 1844) - This species has been regarded as an uncommon species in Norwegian waters, and G.O. Sars (1878) reports a single shell from deep water in Lofoten as well as a few shells from deep water on the western coast. Odhner (1912) adds little to this, only one shell from Bergen and some shells reported by Jeffreys (1870) from Oslofjorden. Not found by Wikander on the Skagerrak coast. My material is limited, but includes seven shells from three stations in the Foldafjorden region at c. $64^{\circ} 40^{\prime}$ to $65^{\circ} \mathrm{N}$, all from gravelly bottom, partly with coral grit, from 200-30 m (steep slopes). In the Møre og Romsdal-series the catch was also limited to seven shells from four stations. In the Espegrend material altogether 20 specimens, principally from Liholmsrennen $\left(60^{\circ} 18^{\prime} \mathrm{N}\right) 60-125$ $\mathrm{m}$ (mostly in the deeper part), gravelly bottom, partly mixed with Modiolula phaseolina.

Emarginula crassa J. Sowerby, 1813 - According to G.O. Sars (1878) not found north of Lofoten, where he reported it to be very rare. Odhner (1912), however reports two shells from Grøtsundet (c. $69^{\circ} 50^{\prime} \mathrm{N}$, c. $200 \mathrm{~m}$, collected in 1861, no further information). Not found by Wikander on the Skagerrak coast.The species appears to be most commonly associated with Lophelia reefs, although also found on rocky bottoms in deeper water. In my material four specimens from the Lophelia reef in Andfjorden ( $69^{\circ} 14^{\prime}$ N, c. 300 $\mathrm{m}$ ), only a single shell from the coast of Nordland, i.e. from the species rich sample from Tomfjorden west of Tomma ( $\left.66^{\circ} 15^{\prime} \mathrm{N}, 300-380 \mathrm{~m}\right)$. Scattered specimens from 100 to $400 \mathrm{~m}$ stations further south, 
but always only a single specimen in each sample.

Emarginula fissura (Linné, 1758) [= Emarginula fissura (Linné, 1767)] - By G.O. Sars (1878) mentioned as pretty scarce from Bodø north to Hammerfest $\left(67^{\circ}\right.$ $\left.15^{\prime}-70^{\circ} 40^{\prime} \mathrm{N}\right)$. Seven samples containing from one to six specimens each recorded by Wikander $(1989,1990)$ from the Skagerrak coast. In my material no specimens north of $67^{\circ} 01^{\prime} \mathrm{N}$, where a single specimen was found in a sample from Fugløyfjorden (70-50 m, rocky bottom with stones and shells of Modiolus modiolus). Altogether 42 specimens were found, of which all but the one mentioned, south of $65^{\circ} 15^{\prime} \mathrm{N}$. Between $67^{\circ}$ and $66^{\circ} \mathrm{N}$, only nine empty shells.

Puncturella noachina (Linné, 1771) - By far the most common species of the family in Norwegian waters, being common and abundant all along the coast (G.O. Sars 1878). Wikander $(1989,1990)$ reports nine samples with altogether 16 specimens from the Skagerrak coast. Usually living between 20 and $300 \mathrm{~m}$ on mixed bottoms. In my material 336 specimens, rather evenly distributed along the coast, with a maximum of 90 specimens in a single sample from Liholmsrennen $\left(60^{\circ} 18^{\prime} \mathrm{N}, 70-55 \mathrm{~m}\right.$, shell gravel and Modiolula phaseolina). In several of the samples from the summer cruises in which numerous Puncturella (max. recorded in a single sample, 11 specimens) were found, also contained much Modiolula phaseolina. A single specimen from $543 \mathrm{~m}$ on the slope just north of the Norwegian Trench $\left(62^{\circ} 20^{\prime} \mathrm{N}\right)$ confirms that it is also occurring on the shelf/upper slope.

Fissurisepta granulosa Jeffreys, 1883 - This species, first recorded from Norwegian waters by Jeffreys (1870) from Drøbak in Oslofjorden c. $100 \mathrm{~m}$, was discussed by Warén (1972a, 1991). He recorded five specimens (in addition to some 200 shells) in three samples from between 300 and $100 \mathrm{~m}$ in Korsfjorden and Hjeltefjorden (between $60^{\circ} 10^{\prime}$ and $60^{\circ} 25^{\prime} \mathrm{N}$ ). In my material three shells from Folda (Revillen, $64^{\circ} 37^{\prime} \mathrm{N}$, 230-110 m, coral gravel) and one from Risværfjorden $\left(65^{\circ} \mathrm{N}, 130-100 \mathrm{~m}\right.$, stones, gravel and coral fragments). Also a single shell from Korsfjorden $\left(60^{\circ} 08^{\prime}\right.$ $\mathrm{N}, 600-360 \mathrm{~m}$, rocks with sponges, clay and coral gravel; coll., leg. et det. A. Warén).

Anatoma spp. - Anatoma crispata has until recently been regarded as the only member of the family Anatomidae in North European waters. Closer scrutiny of my material of some 385 specimens and an additional 560 shells routinely identified as A. crispata, revealed the presence of three distinct forms. One of these fits the generally accepted concept of A. crispata. Another most likely is A. aspera (Philippi, 1844), described from a Calabrian fossil of Pleistocene age. The third is larger and somewhat 'flatter' than the other two, and is most likely an undescribed species. Below I preliminarily name these $A$. crispata, A. aspera and $A$. n. sp. A single, somewhat eroded specimen from the lower slope of the Norwegian Sea, north of the Faroes might belong to a fourth species, tentatively named $A$. cf. umbilicata. This species group is presently under revision and final conclusions will be presented elsewhere.

Anatoma aspera (Philippi, 1844) [= Anatoma crispata (Fleming, 1832) in part] - This species is more globular than A. crispata, only slightly wider than tall, sometimes even taller than wide. The whorls increase less rapidly in diameter, and the axial sculpture is much coarser especially on the shoulder than in A. crispata. The spiral sculpture on the shoulder is weak, and only visible between the axials.The axial sculpture on the base has a somewhat irregular curvature, slightly spiralling in towards the umbilicus. The umbilicus is deep and wide with a deep-set funiculus. The edge of the slit and selenizone is prominent and the selenizone is wider than in the other two species. The shell is grayish white, often with blackish deposit in the cavities between axials and spirals (indicating that it may be living in black, hypoxic sediment). Maximum diameter observed is $3.25 \mathrm{~mm}$. In my material 42 specimens and an additional 47 shells. (I have found very few additional specimens in Norwegian museum collections, and the species is not present in the Wikander material from Skagerrak, nor in his material from Nordland). My northernmost material encompass four specimens and an additional 20 shells from $64^{\circ} 40^{\prime} \mathrm{N}$. Three shells from the two coral reef stations in Andfjorden (69 $\left.14^{\prime} \mathrm{N}\right)$ might also belong to this species, although their morphology is somewhat intermediate between A. crispata and $A$. aspera. I have no indications that the species is present south of Mosterhavn (59 $\left.41^{\prime} \mathrm{N}\right)$. Often found together with Anatoma n. sp. (usually with fewer specimens than the latter) or with A. crispata, in $60-200 \mathrm{~m}$, sandy to gravelly bottoms, in many cases with Modiolula phaseolina shells as dominating substrate. In two samples from gravel bottoms at $80-200 \mathrm{~m}$ in Raunefjorden near Espegrend $\left(60^{\circ}\right.$ $17^{\prime}$ N) in September/October 2007, two specimens of $A$. aspera were found as the only members of the genus. In roughly the same locality as many as 30 specimens of all three species were present in single samples in 1968. 
Anatoma crispata (Fleming, 1828) [= Anatoma crispata (Fleming, 1832) in part] - This, the smallest of our species, rarely exceed $2.35 \mathrm{~mm}$ in diameter. It has a shell shape intermediate between the two other Norwegian species, with a stronger curvature both of the shoulder and base, than in $A$. n. sp. The main characteristics is the rapidly enlarging whorls (width of whorl at the start of the selenizone around $25 \%$ wider than for $A$. n.sp.), the relatively prominent axials on the shoulder (a little less prominent than in $A$. aspera, but more so than in $A$. n.sp.), and fewer and stronger spirals on the shoulder. The axials on the base are slightly prosocline and well separated, but with fewer and less distinct spirals than in the other two species. A narrow funiculus is one of the most important diagnostic characters. From the Skagerrak coast, Wikander $(1989,1990)$ reports altogether 16 specimens from six samples, and I have identified an additional 11 samples with 21 specimens and 10 shells from his further samplings from the same part of the coast. A. crispata was the only species of the genus in these samples, supporting the hypothesis that also the material identified by Wikander belongs exclusively to this species. In my own material, there are altogether 95 specimens (the northernmost are five specimens from Kvæfjorden $68^{\circ} 49^{\prime}$ N, 55-45 $\mathrm{m}$, stones and shells of Arctica) and an additional 400 shells, with an additional 18 specimens and 70 shells from Norwegian museum material. In western Norway (south of c. $63^{\circ} \mathrm{N}$ ) most specimens were from rather exposed localities on the shelf or in the outer fjords, usually in intermediate depths from 50 to 200 $\mathrm{m}$. The species dominate the samples from northern Norway (north of $63^{\circ} \mathrm{N}$ ), where 75 specimens were found. The majority, c. 350, of empty shells are from this part of the coast. Most of the live-caught specimens from this region were taken from shallow (10-25 m), in-shore, hardbottom, environments. Five specimens and seven shells are from two 'transition' stations between the shelf and slope at $543 \mathrm{~m}$ and $602 \mathrm{~m}$ around $62^{\circ} 20^{\prime} \mathrm{N}$. Specimens in museum collections: from the eastern, cold-water Barents Sea $\left(71^{\circ} 42^{\prime} \mathrm{N}, 271 \mathrm{~m},-1.4^{\circ} \mathrm{C}\right.$, The Norwegian North Atlantic Expedition st. 267), from Bøkfjord in SørVaranger (15-10 m; St. 4, 24/6 1937, Tron Soot-Ryen, Tromsø Museum), and from Vadsø (in the Zoological Museum in Oslo) prove that the species is present in the Arctic zone as well.

Anatoma n. sp. [= Anatoma crispata (Fleming, 1832) in part] - The species is most easily distinguished from A. aspera in being more lenticular, having a considerably finer axial sculpture, although the spiral sculpture is more prominent together forming a grid- like surface, especially on the evenly rounded base. When seen from above the sculpture presents a nice, regular pattern. The selenizone is narrow with well developed keels. The margins of the slit are slightly converging.The aperture with somewhat flared lower (especially in young shells) and inner lips, but never extending into the rather narrow umbilicus. Most important is the lack of a funiculus. The protoconch is small and the whorls increase significantly less rapidly than in A. crispata. Live caught specimens have a translucent, yellowish hue, with yellowbrown, powdery deposit in the cavities in the sculptured surface. It is the largest of our three species, reaching at least $4.7 \mathrm{~mm}$ in diameter. In my material 77 specimens and an additional 77 shells, plus 64 specimens and 122 shells from Norwegian museum material (these numbers may be biased because of the large size of the species). My northernmost record from just south of Bodø, $67^{\circ} 10^{\prime} \mathrm{N}$, but material from Tromsø Museum includes three specimens from Lødingen ( $68^{\circ} 25^{\prime} \mathrm{N}, 280-140 \mathrm{~m}$ ), and also an empty shell from Vågsfjord (c. 68 50’ N, 200-160 m). Quite common north to c. $65^{\circ} \mathrm{N}$, but further north largely replaced by $A$. crispata. The large majority in my material from the Espegrend area and from the coast of Møre og Romsdal. Not recorded south of the mouth of Hardangerfjorden except for a few shells (Jeffreys 1870, and the Zoological Museum in Oslo) from Drøbak in Oslofjorden. Not represented in the Wikander material from Skagerrak.

*Anatoma cf. umbilicata (Jeffreys, 1883) - A single, obviously live caught but later dried out, broken and deteriorated (due to 'glass disease'), specimen from the Norwegian North Atlantic Expedition 1876-78, from the deep slope (2222 $\mathrm{m}$ ) just north of the Faroes $\left(63^{\circ} 22^{\prime} \mathrm{N},-1.2^{\circ} \mathrm{C}\right)$ might be a specimen of this little known deep water species. Earlier reports are from the deeper slope outside Portugal, and various sea mounts in the North Atlantic. It is recognized first of all on its flattish whorls with very faint sculpture. Here included because it might be found on the slope outside Norway.

Lepetella laterocompressa (de Rayneval \& Ponzi, 1854) - This species was described from a fossil from Monte Mario in Italy, and by Warén (1972a) identified with a species he found abundantly as empty shells around Espegrend, and also on the northernmost part of the Swedish west coast. He encounterd only a single living specimen though, between Lille Sotra and Sotra $\left(60^{\circ} 20^{\prime} \mathrm{N}, 60-30 \mathrm{~m}\right.$, stones and shell sand). Two specimens in the Zoological Museum in Oslo, without any locality (but according to Jeffreys 
(1883) from the western coast), and determined by G.O. Sars as Lepetella tubicola Verrill \& Smith, 1880, was assumed by Warén to belong to the same species. According to Dantart \& Luque (1994), it is impossible to identify species of this genus on the very variable shells alone. Based on a few external soft part characters they described three species from the Mediterranean and the Bay of Biscay, all of which lived within or on the outer surface of tubes of the onuphid polychaete Hyalinoecia. They concluded that it would be impossible to identify the fossil $L$. laterocompressa with any of the living species, and recommended that this name should be reserved for the fossil form. If this argument is accepted, the species found in Norwegian waters need a new name. It might be identical either to one of two species described by Dantart \& Luque (1994) from the Bay of Biscay, it might be conspecific with L. tubicola described from New England, or it might be an undescribed species. By comparing the only live-caught specimen available (from Oseberg in the North Sea, 60 35' N, $2^{\circ} 49^{\prime}$ E, 106 m, coll. and leg T. Brattegard), I find that L. sierrai Dantart \& Luque, 1994, is the most likely candidate, and should thus probably be used as the name for the species from Norwegian waters. In addition to the records of Warén (1972a), the species has been cited by Brattegard (in Høisæter et al. 1997a) from his sector 11 , which has a northern limit at roughly $63^{\circ}$ $\mathrm{N}$. In my material, in addition to the specimen from the North Sea, five samples with altogether 11 shells from the series from Møre og Romsdal county, and two shells from Foldafjorden, between Gauvene and Tårnfallene $\left(64^{\circ} 40^{\prime} \mathrm{N}, 60-20 \mathrm{~m}\right.$, shell gravel with lots of Hydroidea-tubes).

\section{Clelandella miliaris (Brocchi, 1814) [= Jujubinus clelandi}

(W. Wood, 1828)] - A very common species on mixed and hard bottoms at intermediate depths in Norwegian waters. Recently redescribed by Gofas (2005) who distinguished it from five congeners living at various sea mounts and archipelagos in the northeastern Atlantic. According to G.O. Sars (1878) its northern limit is Lofoten (c. $\left.68^{\circ} \mathrm{N}\right)$. In my material a total of 256 specimens gradually increasing in frequency southwards, from a single specimen found in Gratangen (Hilleshamn, 68 44' N, 70 m rocky bottom), via 21 specimens in 15 samples between $67^{\circ}$ $15^{\prime} \mathrm{N}$, and $66^{\circ} \mathrm{N}$, to 37 in 30 samples between $65^{\circ} 15^{\prime}$ and $63^{\circ} 45^{\prime}$ N. Probably because of undersampling of suitable habitats, only 16 specimens from nine samples were found in the series from Møre og Romsdal county. In the Espegrend area, where several localities with mixed bottoms between 50 and $100 \mathrm{~m}$ have been sampled repeatedly, the number found was 181 from 28 samples. It is obviously not uncommon in the Skagerrak area, as Wikander $(1989,1990)$ reports 11 samples with 34 specimens taken in depths from 24 to $140 \mathrm{~m}$ in this area.

Gibbula spp. - Juveniles of the two species of Gibbula are both common in my material, but may be hard to tell apart, especially shells less than one $\mathrm{mm}$ in diameter. $G$. cineraria is characterized by the colour pattern of 'continuous' olive brown flames, clearly visible also on juveniles around $1 / 2 \mathrm{~mm}$ in diameter. Smaller than that they are completely colourless. Juveniles of this species is flatter than those of G. tumida, and have a more evenly rounded whorl, and with wider and less numerous (six to seven above periphery) spiral lirae. Especially the depressions between the lirae are wider, and dense growth lines are often easily visible. G. tumida also have approaches to a 'keel' on the periphery, giving the whorls a slightly angled appearance. In this species the colour pattern consists of scattered blotches of light brown.

Gibbula cineraria (Linné, 1758) - One of the more common gastropods living on large algae in shallow water all along the coast (G.O. Sars 1878; Odhner 1912). Wikander $(1989,1990)$ reports it from 29 stations with 214 specimens from 8-85 $\mathrm{m}$ depth on the Skagerrak coast.In my material altogether 310 specimens from all the sections except East Finnmark where only a few empty shells were found.

Gibbula tumida (Montagu, 1803) - Common on hard and mixed bottoms in depths from 10 to $100 \mathrm{~m}$ all along the coast although less frequent in Finnmark than further south (G.O. Sars 1878; Schneider 1886; Odhner 1912). Wikander $(1989,1990)$ reports it from 24 stations with 96 specimens from 5-91 m depth on the Skagerrak coast. In my material altogether 808 specimens with a maximum in the fjords in southern Troms (Andfjorden area, between $69^{\circ} 25^{\prime}$ and $68^{\circ} 40^{\prime}$ N) with 354 specimens from 11 samples. Shells only from seven samples in East Finnmark. Further south a variable number in each sector culminating with 259 from 36 samples in the Espegrend area.

Margarites spp. - The experts apparently disagree on the correct gender of this genus name. CLEMAM uses '-a' as the suffix of specific names, while most other experts prefer '-us'. According to Rosenberg (2005) the greek noun 'margarites' is masculine, and the correct ending then presumably is '-us'. In order to be consistent I follow CLEMAM. 
Margarites costalis (Gould, 1841) [= Margarites costalis (Gould, 1841 ex. Lovén MS)] - This northern species, reported to be very common on the Finnmark coast and still not uncommon south to Lofoten (G.O. Sars 1878) is reported as occurring very sparingly in Norway south of Trondheimsfjorden, e.g. Florø (Friele 1876), and Drøbak in Oslofjorden (Odhner 1912). Both of these records apparently refer to living specimens. In my material, 28 specimens and 170 shells from localities north of c. $65^{\circ} \mathrm{N}$ (26 of these 28 specimens are from the Andfjorden area) and 20 specimens from the upper slope (c. $500 \mathrm{~m}$ ) at $62^{\circ} 30^{\prime}$ $\mathrm{N}$ (due west of Ålesund). In addition a single shell from Korsfjorden, NW of Skorholmen $\left(60^{\circ} 09.5^{\prime} \mathrm{N}\right.$, 200-75 m, rocky outcrop with pockets of shell gravel, coll. and leg. A. Warén, 28.10.69). Also a shell from west of Rongøy in Øygarden $\left(60^{\circ} 29^{\prime} \mathrm{N}, 80-75 \mathrm{~m}\right.$, mixture of fine shell sand and clay). Both of these are rather old and worn and cannot be taken as evidence that the species is still living here.

Margarites helicina (Phipps, 1774) $[=$ Margarites helicinus] - Reported by G.O. Sars (1878) to be common all around the coast on algae, especially kelp, in the lower littoral and upper sublittoral. Wikander (1990) collected 63 specimens from five localities on the Skagerrak coast. In my material 287 specimens pluss an additional 130 shells. From East Finnmark, I have only empty shells. Further south, in the Andfjorden area as well as in bays and fjords in Nord-Trøndelag (where samples were taken from very shallow bottoms, 0.5 to $10 \mathrm{~m}$ ) several samples containing from 10 to 100 specimens each. In the Møre og Romsdal series, 31 specimens from eight samples, and 121 specimens in 13 samples from around Espegrend.

Margarites olivacea (Brown, 1827) - G.O. Sars (1878) introduced this species to the Norwegian fauna based on three specimens found at three different localites in northern Norway, between Lofoten and Vardø. Schneider (1886), Norman (1902) and Odhner (1912) reported the species in several additional localities from Tromsø and northwards. In my material found at five stations in East Finnmark. Except for one specimen from Varangerfjorden outside Kiby (220 $\mathrm{m}$, soft bottom) and three from Holmengråfjorden (60-65 m, sand and mud and old shells) only empty shells.

Margarites striata (Leach, 1819) [= Margarites groenlandicus (Gmelin, 1791)] - M. groenlandica is still used in Clemam, while Smith \& Heppell (1991), and Warén (in Hansson 1998) (among many others) follow Rehder (1990) in that M. groenlandicus is really a distinct Arctic species, so far not reported as extant from Norwegian waters. After having seen a Quarternay fossil of the latter, I fully agree with Rehder. M. striata is found along the whole coast, at least south and east to Mandal (58 $01^{\prime} \mathrm{N}, 7^{\circ} 28.5^{\prime}$ $\mathrm{E}$, based on a single specimen from $16 \mathrm{~m}$, Wikander 1990) The only other record from the Skagerrak area seems to be three shells from Farsund (Odhner 1912). It is rather more common in northern than in western Norway. In my material 400 specimens and an additional 350 shells from all sectors, but with a maximum of 233 specimens in the Andfjorden region. In my samples from East Finnmark I have only empty shells. In the fjords in southern Troms (Gratangen and Grovfjord, c. 68 $40^{\circ} \mathrm{N}$ ), the species proved to be abundant in depths of 20-50 m on rocky bottoms covered with algae. In the Espegrend area 64 specimens were found in 17 samples from current swept, shallow water (5 to $15 \mathrm{~m}$ ) localities with coarse shell sand. It is perhaps of some significance that 60 of these specimens were found in 1965, 1966 or in January 1967 , but only a total of four specimens in some 30 samples from suitable localities were found later in the sixties and the early seventies.

Solariella spp. - The Norwegian species of Solariella were revised by Warén (1993), and I follow him consistently.

Solariella amabilis (Jeffreys, 1865) [= Solariella cincta (Philippi, 1836)] - Warén (1993), synonymized $S$. cincta (auct., not Philippi, 1836) and S. affinis (Friele, 1877) with S. amabilis. Warén appears to have made an unfortunate choice of illustrations in his revision. In the text he claims his Fig. 2B to represent Machaeroplax affinis of Friele, with the type locality 'Bergensfjorden', but the figure is based on a shell from west of the Strait of Gibraltar, and it does not match the description: '...a more finely sculptured form with evenly rounded whorls...'. Friele (1874) mentions that his specimens diverged considerably from Jeffreys' descriptions and drawings of S. amabilis, and his observations of the living animal also differed from Jeffreys' description. Friele \& Grieg (1901), after having again carefully studied the arguments of Jeffreys concerning the synonymy, maintain that $S$. affinis is specifically distinct from $S$. amabilis, and that $S$. amabilis does not live in Norway. My material look rather different from both illustrations in Warén (1993), but might fit the description above of 'affinis'. In Norway this species has been recorded from western Norway from $60^{\circ}$ to $69^{\circ} \mathrm{N}$, as well as the northern North Sea, in depths of 150-800 m (Warén 1993). The species is found sparingly in my 
samples from the Bergen area (Fedjeosen, c. $60^{\circ}$ $45^{\prime} \mathrm{N}, 220-140 \mathrm{~m}$, rocky bottom), but is quite plentiful on the shelf further north, around $62^{\circ} \mathrm{N}$, and on the western 'slope' of the Norwegian Trench $\left(61^{\circ} 30^{\prime} \mathrm{N}\right)$. Several samples contain from 20 to 80 specimens.

Solariella obscura (Couthoy, 1838) [including Solariella laevis Friele, 1886] - According to Warén (1993) this is a predominantly Arctic species, but in deeper waters going south to the Faroes. The information in the literature concerning the southern limit in Norwegian waters is confusing. Odhner (1907) have no records south of Lofoten while Warén (1993) gives the southern limit on the Norwegian coast as $64^{\circ} \mathrm{N}$ (off Trondheimsfjorden, 200-225 m). Sneli (in Sneli et al. 2005) repeats this, but in an earlier paper (Sneli 1979) he records the species as present just outside Sognefjorden $\left(61^{\circ} \mathrm{N}\right)$, apparently based on Friele \& Grieg (1901). Brattegard (in Høisæter et al. 1997a) records it from both sector 8, 9, and 10 , from the Bergen area and north to and including Sognefjorden. The documentation for these southern records is lacking, and I have not been able to trace the reference to $S$. obscura from just outside Sognefjorden in Friele \& Grieg (1901). According to Warén only glacial fossils are present in inshore waters of western Norway. In my material one specimen from Gratangen $\left(68^{\circ} 44^{\prime}\right.$ N, 70 m, rocky bottom), a juvenile from Sveinsgrunnen ( $69^{\circ} 31^{\prime} \mathrm{N}, 162$ $\mathrm{m}$ ) and four from East Finnmark (Småstraumen close to the Russian border, 12-4 m, sand and shell sand). I also have 53 specimens from five stations at depths of 497 to $804 \mathrm{~m}$ on the slope $\left(62^{\circ} 20^{\prime}-62^{\circ} 30^{\prime} \mathrm{N}\right)$. The temperature varied from $+2.2{ }^{\circ} \mathrm{C}$ to $-0.9{ }^{\circ} \mathrm{C}$ in these slope stations.

Solariella varicosa (Mighels \& Adams, 1842) - An Arctic species in Norway only recorded from East Finnmark (Odhner 1912). In my material seven specimens from one station in East Finnmark, the inner part of Varangerfjorden (SW of Vestre Jakobselv, 70 $04^{\prime} \mathrm{N}$, $174 \mathrm{~m}$, fine sand).

Calliostoma occidentale (Mighels \& Adams, 1842) [= Calliostoma formosa (McAndrews \& Forbes, 1847)] - According to G.O. Sars (1878) common along the west and north coast from around 50 to $300 \mathrm{~m}$. The occurrence further south is reported to be rather spotty, and it has not been reliably reported south of Hardangerfjorden (c. 60 $0^{\circ}$ N) (Grieg 1914). Odhner (1912) reports one specimen on the western slope of the Norwegian Trench at c. $300 \mathrm{~m}, 58^{\circ} 55^{\prime} \mathrm{N}$, $3^{\circ} 28^{\prime}$ E. Not mentioned in Wikander $(1989,1990)$, but according to Wikander (in litt.) a single juvenile specimen has been dredged from deep water outside Tromøya ( $\left.58^{\circ} 25^{\prime} \mathrm{N}, 8^{\circ} 55^{\prime} \mathrm{E}\right)$. In my material nine specimens together with 24 shells from East Finnmark to the Espegrend area, the northernmost specimen from Røssøysundet, near Inndyr ( $67^{\circ} 04^{\prime}$ $\mathrm{N}$, 50-30 m, stones, shell and shell gravel).

Calliostoma zizyphinus (Linné, 1758) - This spectacular gastropod is usually found on or near hapteres and stipes of Laminaria hyperborea and other kelp species from the wave-exposed outer coast. G.O. Sars (1878) reports it from the southern coasts, from Oslofjorden and 'Ora occident. Norv.'. Soot-Ryen (1951) extended the known distribution northwards to $66^{\circ} 56^{\prime} \mathrm{N}$. Brattegard (in Høisæter et al. 1997a) reports it from each of his sectors north to sector 17 (ending at $67^{\circ} 40.5^{\prime} \mathrm{N}$ ), except sector 14. Not mentioned in Wikander $(1989,1990)$ from Skagerrak though, and according to him (Wikander in litt.) never found in the Skagerrak region. Reported as rare from Bohuslän in Sweden (Hansson 1998). Probably grossly undersampled in my material, only 23 specimens recorded, all from the Espegrend area, where it is quite common. A single shell from Trondheimsleia $\left(63^{\circ} 24^{\prime} \mathrm{N}, 40-10 \mathrm{~m}\right)$ is the only material from north of Bergen.

Danilia tinei (Calcara, 1839) - Most authors (e.g. Smith \& Heppell 1991, and Warén in Hansson 1998) seem to prefer the older name Danilia otaviana (Cantraine, 1835), but for consistency I follow CLEMAM. This southern species has so far only been recorded in Norway from Hardangerfjorden $\left(59^{\circ} 30^{\prime} \mathrm{N}\right)$ and the Bergen area (Grieg 1914). Outside Norway very sparingly recorded from the North Sea, the shelf/slope west of Ireland and in the Mediterranean (Odhner 1912, Grieg 1914). In my material three specimens from the Espegrend area. The most recent from Raunefjorden $\left(60^{\circ} 17^{\prime} \mathrm{N}, 5^{\circ} 12^{\prime} \mathrm{E}, 72-52 \mathrm{~m}\right.$, rocks and gravel, July 1970). Before that a specimen from Liholmsrennen $\left(60^{\circ} 18^{\prime} \mathrm{N}\right.$, c. $100 \mathrm{~m}$, slag and small stones, August 1967), and one shell from a Lophelia reef in Hjeltefjorden $\left(60^{\circ} 24.5^{\prime} \mathrm{N}, 120 \mathrm{~m}\right.$, coral rubble, April 1963). Not a common species in Norwegian waters, only single animals collected several years apart.

Moelleria costulata (Møller, 1842) - According to G.O. Sars (1878) found between three and $100 \mathrm{~m}$ in western and East Finnmark, but not in the Lofoten area. Found by Schneider (1886) around Bodø (c. $67^{\circ} 20^{\prime} \mathrm{N}$ ), presumably the southern limit for its distribution (although reported by Sneli (in Sneli et al. 2005) and Brattegard (in Høisæter et al. 1997a) 
from Nord-Møre; whether this record refers to shells or specimens is not known). Known as subfossil also from Bohuslän. In the Wikander material from Nordland, a very nice sample of 32 specimens from $\mathrm{B} \varnothing$ in Vesterålen $\left(68^{\circ} 42^{\prime} \mathrm{N}\right.$, inside a small treshold fjord between 20 and $10 \mathrm{~m}$, sand w/Laminaria saccharina), and one specimen and 23 shells from three further stations around Bodø. In my material 18 shells from the coast SW of Bodø $\left(67^{\circ} 15^{\prime} \mathrm{N}\right)$; two worn, small shells from Stokksundet (64 $03^{\prime}$ N, 120 $60 \mathrm{~m})$; one worn shell from Rovdefjorden $\left(62^{\circ} 12^{\prime}\right.$ $\mathrm{N})$; two shells from Korsfjorden (60 $09^{\prime} \mathrm{N}, 200-75$ $\mathrm{m}$, steep rocky slope with pockets of shell grit, coll and leg. A. Warén) and one very worn shell (almost smooth on top) from Liholmsrennen $\left(60^{\circ} 18^{\prime} \mathrm{N}, 100\right.$ $60 \mathrm{~m}$, Modiolula phaseolina gravel, silt and sand). The Wikander material (see above) also contained a single, worn shell from around Grimstad (58 $20^{\circ} \mathrm{N}$, $8^{\circ} 38.5^{\prime} \mathrm{E}, 50 \mathrm{~m}$, shell sand). These latter ones are far south of its known present day distribution, and are presumably subfossils.

Skenea spp. - This group, which has previously been revised by Warén $(1991,1993)$ is under yet another revision, and will be only superficially treated here. I recommend a close study of the two papers by Warén, for getting a good grasp of this difficult group.

Skenea areolata (G.O. Sars, 1878) - This characteristic, somewhat flattened, reticulated shell has so far been considered a rare species, only known from empty shells. The species was described from a few well preserved shells taken from shell grit from the banks west of Vesterålen, 146-182 m. In the latest revision Warén (1991) was able to relocate only a single syntype from 'Finnmarken' (probably Vesterålen according to Warén) in USNM. In addition he mentions one shell from the slope north of Andøya (1187 $\mathrm{m})$, and three shells from western Iceland. Friele \& Grieg (1901) in addition to the shell from the slope north of Andøya, recorded it from another, somewhat deeper $(550 \mathrm{~m})$ locality west of Vesterålen. They mention that Jeffreys (1883) found two specimens in the Faroe-Shetland channel, confirmed by Simpson (1910). This latter record was not mentioned by Warén, and may be doubtful. In my material 18 shells (together with shells of seven other skeneid species) from two coral reef stations in Andfjorden (69 $14^{\prime} \mathrm{N}$, $370 \mathrm{~m}$ ), and three shells from the deep dredge haul in Bleiksdjupet $\left(69^{\circ} 25^{\prime} \mathrm{N}, 700-200 \mathrm{~m}\right)$. These finds are in accordance with the older records, but it turned out to be much more abundant further south. This encompass two specimens from a 50-30 m station, and seven shells from three stations just southwest of
Bodø $\left(67^{\circ} 15^{\prime} \mathrm{N}\right)$, and three specimens and 14 shells from three stations in the outer parts of Foldafjorden in Nord-Trøndelag ( $64^{\circ} 40^{\prime} \mathrm{N}, 60-20 \mathrm{~m}$, shell gravel). In the Wikander material from Nordland, two specimens and four shells from the Bodø region. The species thus seems to have its distributional centre in fairly shallow water, $60-20 \mathrm{~m}$ on mixed, gravelly bottom, on the outer coast south of Lofoten, south to around $64^{\circ} 30^{\prime} \mathrm{N}$.

Skenea basistriata (Jeffreys, 1877) s.l. - I have split S. basistriata s.l. into two species groups. All material from soft bottoms in the deep fjords and on the shelf outside as well as in the Norwegian Trench, is assigned to $S$. basistriata s.str. The material from the slope from 470 down to $1338 \mathrm{~m}$ is assigned to two undescribed species, Skenea aff. proxima and Skenea n. sp. A.

Skenea basistriata (Jeffreys, 1877) s.str. - This species was last discussed by Warén $(1991,1993)$ who concluded that it is a highly variable species, and that he was not able to sort out any subgroups that might be accepted as separate species. I fully agree that as far as the conchological characters go it is a most variable species, but there are some patterns to this variability, and Warén may have included a bit too many forms within the species concept. Consequently I have looked closer at a rather extensive material from the slope in the transitional zone between water with positive and negative temperatures, and decided that the specimens falling within Warén's S. basistriata in this zone really represent two undescribed species (see Skenea aff. proxima and Skenea n.sp. A below). What remains may anyway be the commonest Skenea in Norwegian waters, with a preponderance on deep silt/clay fjord bottoms and on the silty shelf. In these environments, the species may very well be the single Skenea present, and one of the numerically dominant gastropods as well. The distribution is apparently rather limited geographically. G.O. Sars (1878) reported it to be abundant in the Lofoten area (presumably in Vestfjorden, between Værøy, $67^{\circ}$ $50^{\prime} \mathrm{N}$ and Risvær, $68^{\circ} 18^{\prime} \mathrm{N}$ ) from 220 to $550 \mathrm{~m}$. He had no records from the coast north of this area. Schneider (1886) did not report it from the fjords around Tromsø. Warén (1991, 1993), however added a number of localities from the shelf and slope in northern Norway, north to at least $69^{\circ} 45^{\prime} \mathrm{N}$, a couple of specimens from shallow water around Spitsbergen, and a number of localities north of Siberia, at c. $80^{\circ}$ $\mathrm{N}$, and depths from c. 70 to c. $300 \mathrm{~m}$. These may or may not belong to $S$. basistriata s.str., but in light of my subdivision of the 'species' they should be 
reexamined. Records from southwestern and southern coasts and fjords are scarce. G.O. Sars (1878) mentions that it is fairly abundant along the whole western coast at least south to Kvitsøy $\left(59^{\circ} 05^{\prime} \mathrm{N}\right)$. Warén (1993) adds a single record (two specimens) from the deeper part of the Norwegian Trench in Skagerrak, due south of Larvik (58 31' N, $545 \mathrm{~m}$ ). It is not mentioned in Wikander $(1989,1990)$ from Skagerrak, and not present in the Wikander material from Skagerrak. Three specimens and one shell are present in the Wikander material from Nordland.

In my material a single specimen from north of $68^{\circ}$ N. Out of a total of some 190 Skenea's, mostly shells, from the Andfjorden area, a single juvenile (c. 1.0 $\mathrm{mm}$ diameter) specimen from outer Gratangen $\left(68^{\circ}\right.$ 44' N, 80-90 m, mixed substrate with much fine sediment) and no shells, could be assigned to this species. This specimen may represent the northern distributional limit for the species. The 32 specimens from 11 stations spread along the coast southward from $67^{\circ}$ $15^{\prime} \mathrm{N}$ in the material from Nordland, testifies to the ubiquity of the species along this section of the coast. Between $65^{\circ} 25^{\prime} \mathrm{N}$ and $64^{\circ} \mathrm{N}, 24$ specimens from 13 stations were recorded. However, in the numerous soft bottom, deep water samples from Bindalsfjorden, only scattered shells were found. Further south, from Møre og Romsdal county, 16 specimens from 10 stations were found. The richest material I have is from the fjord and shelf stations south of $62^{\circ} 30^{\prime}$ N. From this material I have sorted out 135 specimens from 15 stations, of which 10 were fjord and five shelf (incl. Norwegian Trench) stations. The main difference in shell sculpture is found between typical deep fjord populations and populations found in the northern part of the Norwegian Trench outside the coast, while typical shelf stations are somewhat intermediate.

Skenea ossiansarsi Warén, 1991 [= Skenea laevigata (Friele, 1876)] - This is one of the smaller members of the genus, rarely exceeding $1.5 \mathrm{~mm}$ in diamter. The reasons for describing it as a new species is detailed in Warén (1991) in the discussion of S. trochoides. I do not fully agree with Warén in this matter, and would have liked to reinstate the old name S. laevigata. For consistency I use the name accepted in CLEMAM. The known distribution in Norwegian waters of this species is based on the information in G.O. Sars (1878) ('Finm. occident., 'Insulae Lofoten., 'Ora occident Norw.') and Warén's own material (30 samples with around 310 specimens) from the shelf and fjords around Bergen $\left(60^{\circ} 09^{\prime} \mathrm{N}\right.$ to c. $\left.60^{\circ} 30^{\prime} \mathrm{N}\right)$. Not mentioned from Skagerrak in Wikander $(1989,1990)$. In my material altogether 35 specimens (and an additional 300 shells) spread along the whole coast from the Andfjorden area to Bergen. In the latter region seven specimens from a total of seven samples, most of which contained shells only. Sparely represented in the material from Møre og Romsdal county, only five specimens (and 25 shells) in four samples. Better represented in the material from Nord-Trøndelag and southern Nordland, with 12 specimens (and 145 shells) from 10 samples. A 'typical' sample is the one from Risværfjorden, SE of Steinsøya (64 59’ N) with seven well-preserved specimens. This station had a depth of c. $25 \mathrm{~m}$, and the substrate consisted of stones, gravel, slag and red algae. Further north, from $65^{\circ} 40^{\prime}$ to $67^{\circ} 15^{\prime} \mathrm{N}$, seven specimens (and 140 shells) in 19 samples, and finally, three specimens from the rich station in Gratangen (68 44' N, 90-80 $\mathrm{m}$, fine shell sand) in addition to 63 shells from three deep water, and Lophelia reef stations at $69^{\circ} 25^{\prime} \mathrm{N}$, $69^{\circ} 14^{\prime}$ N. Although G.O. Sars (1878) did not give any further details as to his material from western Finnmark, I have no reason to doubt that it occurs there on the outer coast. The overwhelming majority of my specimens are from depths between 10 and $60 \mathrm{~m}$, and the few remaining are from current swept very rough bottoms down to $270 \mathrm{~m}$.

Skenea peterseni (Friele, 1877) - Described by Friele from material from the Norwegian North Atlantic Expedition, but reliably distinguished from S. trochoides first by Warén (1991). According to Warén $(1991,1993)$ this species is quite rare in Norwegian waters, occurring mainly on the upper slope and outer shelf. Friele's original material was from the upper slope outside mid Norway $\left(63^{\circ}-64^{\circ} \mathrm{N}, 911\right.$ and $928 \mathrm{~m})$ and Warén $(1991,1993)$ was only able to add two shells from the shelf outside Korsfjorden $\left(60^{\circ} 06^{\prime}\right.$ to $60^{\circ} 08^{\prime} \mathrm{N}$ ), and a single shell from the deeper part of the Norwegian Trench, $654 \mathrm{~m}$ in the Skagerrak.

In my material, 15 samples contain material of this species, with altogether 19 specimens and c. 48 shells. Of these, four specimens and all the shells are from coastal stations from the outer coast in northern Norway, the southernmost from coastal waters from Tomfjorden, $66^{\circ} 15^{\prime} \mathrm{N}$, while 14 specimens are from four stations on the upper slope $\left(62^{\circ} 20^{\prime}\right.$ to $63^{\circ} \mathrm{N}, 0^{\circ}$ $55^{\prime}$ to $1^{\circ} 44^{\prime}$ E, 543-830 m). Not all of these are equally convincing, as the borderline between $S$. petersen, $S$. basistriata and $S$. trochoides is kind of fuzzy. The most convincing samples are the ones from the slope around $62^{\circ} 30^{\prime} \mathrm{N}$, of well preserved specimens with eyes and other soft parts visible through the shell. Many of the rest are identified on 'negative' characters, they are all lacking basal sculpture except for umbilical ribs. The majority of the shells are rather tightly coiled with a narrow slit-like umbilicus, but 
others are very loosely coiled. A single shell (with dried remains of the animal inside) from a shallow water station SW of Bodø $\left(67^{\circ} 16^{\prime} \mathrm{N}, 13 \mathrm{~m}\right)$ with very coarse bottom substrate, approach the condition in Skenea polita Warén, 1993. In the same sample, one specimen and four shells more in line with the 'standard' for S. peterseni. It is hard to accept that these shallow water shells, which also are quite a bit smaller than the ones from the slope at same number of whorls, to be conspecific with the latter, although no other described shells are getting even close.

*Skenea profunda (Friele, 1879) - According to Warén (1991) only known from the material listed in Bouchet \& Warén (1979), i.e. the original material from the Norwegian North-Atlantic Expedition, and 17 specimens from the 1975 NORBI-expedition tentatively (since they were badly damaged by acidic formalin) assigned to this species. All of these latter records are from depths between $2900 \mathrm{~m}$ and $3300 \mathrm{~m}$ in the abyssal Norwegian Sea, north of $69^{\circ} \mathrm{N}$. Described by Friele (1879) from two localities west of Spitsbergen, one from $2440 \mathrm{~m}$ (presumably to be accepted as type locality) and one from $229 \mathrm{~m}$ on the shelf west of Spitsbergen. Bouchet \& Warén (1979) argued that the latter locality most likely was wrong, and that the shells from this locality really was contamination from the abyssal type locality further west. The 229 $\mathrm{m}$ station was the one immediately succeeding the sampling of the type locality. I find this conclusion reasonable, especially when viewed in the light of the remark in Friele (1886), that the species occurred pretty abundantly at the deeper station in a piece of wood perforated by Teredo. Material from a third locality listed by Friele (1886), a station on the slope (1187 m) west of Senja $\left(69^{\circ} 46^{\prime} \mathrm{N}\right)$, was not discussed by Bouchet \& Warén (1979), and should be reexamined before being accepted. Probably not part of the marine fauna of Norway as here defined.

Skenea aff. proxima (Tryon 1888) - Based on two specimens from the upper slope taken several months apart at more or less the same locality $\left(62^{\circ} 29^{\prime} \mathrm{N}\right.$, $1^{\circ} 44^{\prime}$ W, c. $600 \mathrm{~m}$, coll. T.Brattegard), with positive temperature the first time and negative the second $(+$ $1.1^{\circ} \mathrm{C}$ and $-0.9^{\circ} \mathrm{C}$ ). In both samples they were found together with several specimens of Skenea $\mathrm{n} . \mathrm{sp}$ A and S. peterseni.

Distinguishing characters: Medium large for genus, diameter to $2.6 \mathrm{~mm}$. Eyes large (the right one very close to the upper suture). Very fine incised spiral lines around the umbilicus, the rest of the shell apparently smooth (but see below). Umbilical opening narrow (narrower than in any of the other species in this group) and partly concealed by the inner lip adhering to the body whorl. A little flattening and wing-like extension of the lower inner lip, forming a secondary channel into the umbilicus. No internal thickening of the aperture. Shell less translucent and less glossy than similar sized shells of $S$. basistriata. Border between protoconch and teleoconch not as distinct as for the other species in this group, apparently with 1 $1 / 2$ whorl, and a total diameter of $520 \mu \mathrm{m}$. The surface of protoconch and first half whorl of teleoconch corrugated (the whole surface densely covered with microscopically small pits), no sign of spiral lines or keels at start of teleoconch as in S. basistriata, $S$. n.sp. A and S. profunda. Somewhat larger than $S$. basistriata with the same number of whorls. $S$. proxima was described from North American material, and there is so far no indication that it should occur on this side of the Atlantic (see Warén 1991:65). According to Warén it has a polished shell with fine spiral sculpture, almost as fine as in S. rugulosa. In my specimens the fine spiral sculpture is only present on the base around the umbilicus, consisting of roughly 15 very close-set incised lines. The rest of the shell with slight, very close-set, axial 'plications', only visible with good lightning. Not easily characterised as 'polished'.

Skenea rugulosa (G.O. Sars, 1878) - This small (max. diam. $1.6 \mathrm{~mm}$ ) Skenea without eyes was described by G.O. Sars (1878) from three specimens from Lofoten. According to his distributional tables it should also occur in western Finnmark, and its bathymethrical distribution should be from 150 to $370 \mathrm{~m}$. Warén (1991) expanded the distribution to western Norway (the fjords around Bergen). Wikander (1989) reported one doubtful ('cf.') specimen from 85 m outside Flekkefjord (58 $\left.18^{\circ} \mathrm{N}\right)$.

In my material, the majority of the specimens are associated with Modiolula phaseolina substrate from intermediate depths, $40-100 \mathrm{~m}$. Several shells at three stations in the Andfjorden area, the two Lophelia reef stations, and the one in outer Gratangen. But only the species rich station in outer Gratangen $\left(68^{\circ} 44^{\prime} \mathrm{N}\right.$, 80-90 m, mixed substrate with much fine sediment, and lots of Modiolula phaseolina) contained a live specimen. Nine stations in the series from Nordland from $67^{\circ} 15^{\prime} \mathrm{N}$ to $66^{\circ} \mathrm{N}$, intermediate depths and shell sand, seven stations in the series from $65^{\circ} 15^{\prime} \mathrm{N}$ to $64^{\circ} 30^{\prime} \mathrm{N}$, and finally four stations in the Møre og Romsdal series from $63^{\circ} \mathrm{N}$ to $62^{\circ} 15^{\prime} \mathrm{N}$, contained a total of 30 specimens. A number of records from the Herdla/Espegrend area, three samples from Herdla with altogether seven specimens, and one from Fleslandsskjær, Raunefjorden $\left(60^{\circ} 17.5^{\prime} \mathrm{N}, 80-60 \mathrm{~m}\right.$, 
mixed bottom) with three specimens.

Skenea trochoides (Friele, 1876) [= Skenea peterseni (Friele, 1877) in part] - First reliably set apart from $S$. peterseni and $S$. ossiansarsi by Warén (1991). His list of Norwegian records is however very limited, comprising only the types and his own material from the fjords around Bergen, from $60^{\circ} 08^{\prime} \mathrm{N}$, to $60^{\circ} 50^{\prime} \mathrm{N}$, and four syntypes from Florø $\left(61^{\circ} 35^{\prime} \mathrm{N}\right)$. He did not report any finds from Norway north of Florø, but did include a number of samples from Franz Josef Land! In my material 67 specimens and close to 500 empty shells, and evidently, next to Skenea basistriata, the commonest species of Skenea in our waters. In the Espegrend/Herdla area, 27 specimens from 10 stations. In the Møre og Romsdal series only three specimens and 33 shells from three stations. In the Nord-Trøndelag material 19 specimens and more than 340 shells from 15 stations. In the samples from between $65^{\circ} 25^{\prime} \mathrm{N}$ and $67^{\circ} 15^{\prime} \mathrm{N}, 16$ specimens and about 120 shells from 13 stations. In this latter material the distinction between species seems to be exceptionally fuzzy e.g. those from the two shallow water stations SW of Bodø, (see also S. peterseni). In several samples a mixture of $S$. trochoides and what I now regard as $S$. peterseni were originally listed as S. trochoides. In the material from the Andfjorden series, one specimen and 30 shells were found in four samples. The first Lophelia reef sample south of Ørja, Senja, $\left(69^{\circ} 14^{\prime} \mathrm{N}-16^{\circ} 41^{\prime} \mathrm{E}, 370 \mathrm{~m}\right.$, coral reef on moraine) contained a number of well preserved shells. Juveniles of this species overlap conchologically with $S$. ossiansarsi, while adults may be mistaken for $S$. peterseni. I have renamed all specimens without trace of the curved radial lines crossing the growth lines and spiralling towards the umbilicus, as S. peterseni.

*Skenea turgida (Odhner, 1912) - Described from 16 specimens from two stations west of Spitsbergen (c. $78^{\circ} \mathrm{N}, 2700$ to $2750 \mathrm{~m},-1.4^{\circ} \mathrm{C}$ ). Max. diameter of these $1.6 \mathrm{~mm}$ (Odhner 1912). Later Bouchet \& Warén (1979) reported abundant material from 2900-3700 m depth in the Norwegian Sea (from c. $65^{\circ} \mathrm{N}$ to $69^{\circ} \mathrm{N}$ ). Especially abundant at the southernmost of these stations, at $65^{\circ} 45^{\prime} \mathrm{N}$. Most recently discussed in Warén (1991), where a record from off Tromsø, $350 \mathrm{~m}$ was added. In my material three specimens, one from the slope northeast of the Faroes, and two from the lower slope $\left(1260 \mathrm{~m},-0.9{ }^{\circ} \mathrm{C}\right.$, and $3892 \mathrm{~m},-0.8^{\circ} \mathrm{C}$ respectively). Since all records except the one from $350 \mathrm{~m}$ off Tromsø are from negative temperatures and depths beyond $1200 \mathrm{~m}$, I will not exclude the possibility that the Tromsø record is a misidentification.
Probably not part of the marine fauna of Norway as here defined.

Skenea n.sp. A - [= Skenea basistriata (Jeffreys, 1877) in part] - Based on 64 specimens from 10 stations from the slope, from 473 down to $870 \mathrm{~m}$, with temperatures from $+6.3{ }^{\circ} \mathrm{C}$ to $-0.9{ }^{\circ} \mathrm{C}$, (most of the material from the upper slope, from 473 to $604 \mathrm{~m}$, only a couple specimens from depths beyond $700 \mathrm{~m}$ ) from off Storegga outside Kristiansund ( $\left.63^{\circ} 10^{\prime} \mathrm{N}\right)$ south to $62^{\circ} 12^{\prime} \mathrm{N}$. At the shallower of these stations no other skeneids were found, but it was accompanied by $S$. peterseni and S. aff. proxima at two $600 \mathrm{~m}$ stations. Also one specimen from the Faroe-Shetland channel from $1220 \mathrm{~m}$. This species undoubtedly is included in Warén's (1991, 1993) concept of S. basistriata, and is closely compared to that species below. Skenea n.sp. A might be identical to Cyclostrema willei Friele, 1886 (synonymized with $S$. basistriata by Warén 1991), but the large, completely open umbilicus and widely spaced, raised lirae argue against this conclusion.

Distinguishing characters: Medium large for the genus, max. diameter c. $2.6 \mathrm{~mm}$. With small eyes (only the right one visible) marginally larger than those of $S$. basistriata, a bit further from the suture than those of $S$. aff. proxima. The nucleus is small and almost level with the first teleoconch whorl, extending for about one whorl. In S. basistriata, the nucleus is large and bulbuous, and protrudes somewhat from the succeeding parts of the shell. Whorls increasing less rapidly than in S. basistriata, and thus smaller at the same number of whorls, but eventually growing to a larger size than S. basistriata. Max. diam. for $S$. basistriata in my material c. $2.2 \mathrm{~mm}$. (Fig. $16 \mathrm{D}$ in Warén (1993) with a diameter of $2.38 \mathrm{~mm}$, from BIOFAR st. 027 (225 $\mathrm{m}$ on the shelf east of the Faroes), may be a specimen of Skenea n.sp. A). The border between protoconch and teleoconch distinct, and with two or three spiral lirae on the top and side of the whorl starting at the border, while in S. basistriata a single very strong spiral ridge appears on top of the whorl immediately at the break, sometimes to be followed shortly by several more lirae. The spiral sculpture of the teleoconch varies in S. basistriata, sometimes covering the whole body with somewhat irregularly spaced and variously strong lirae. More commonly these are found mainly on the base, with a limited number on top of the upper whorls, while the intermediate part of the shell is smooth. In Skenea n.sp. A the whole of the shell is covered densely with irregularly spaced lirae. These are finer than the ones of S. basistriata and may number up to 35-40 on the body whorl, the last c. six spiralling into the umbi- 
licus. In Skenea n.sp. A, especially on larger specimens, the lowermost lirae are thickened, somewhat irregular and 'crowded' where they disappear into the umbilicus as a furrowed 'wedge'. Umbilical opening is fairly large, but smaller and less 'open' than in $S$. basistriata. Aperture with a thickened, somewhat 'outbended' rim in fully grown specimens.

Skenea n.sp. B - Based on one shell from each of the two coral reef stations in Andfjorden. Apparently an undescribed species. The two, are 1.0 and $1.3 \mathrm{~mm}$ in diameter respectively, very flat and with characteristic narrow, sinuous axial ribs. Clearly different from all the forms described recently by Warén (1991, 1993a, b), although similar in shape to his Akritogyra helicella Warén, 1993, from southwestern Iceland. This species has only traces of axial sculpture though.

*Anekes undulisculpta Bouchet \& Warén, 1979 - The genus is discussed in Warén (1992), where also the radula of the species is illustrated and described. According to Bouchet \& Warén (1979) rather abundant in samples from the abyssal parts (depths below $2500 \mathrm{~m}$ ) of the Norwegian Sea. Apparently not encountered since the orginal description. In my material, two specimens from $2090 \mathrm{~m}$ at $63^{\circ} 36^{\prime} \mathrm{N}$, unfortunately partly dissolved by acidic formaldehyde. Probably not part of the marine fauna of Norway as here defined.

Dikoleps nitens (Philippi, 1844) - Warén (1991, 1992, 1993) distinguishes between $D$. nitens and $D$. pusilla (Jeffreys, 1847), the latter of which should be the correct name of the Norwegian material. Clemam still regards $D$. pusilla as a synonym of $D$. nitens, however. This southern species has so far been reported north to Bodø (67 $\left.20^{\circ} \mathrm{N}\right)$ (Warén 1993), and, as opposed to all the Norwegian species of Skenea, is a typical shallow water species, never having been found alive deeper than c. $50 \mathrm{~m}$. It is a very small species, rarely exceeding $1 \mathrm{~mm}$ in diameter (one shell from Scotland, illustrated in Warén (1991) is stated to be $1.1 \mathrm{~mm})$. Not mentioned from Skagerrak in Wikander $(1989,1990)$, but seven shells from two samples in the Wikander material from Skagerrak. In my material a lot of eight, not particularly fresh looking, shells from Steinavær in Andfjorden (69 $14^{\prime}$ N, 370 m, coral reef) could thus be a new northern distributional limit for the species. These eight shells are all around $1 \mathrm{~mm}$ in diameter. This lot is the only one found north of Bodø. The lack of material from the many shallow water stations in the Gratangen and Hinnøy area, make it unlikely that the species is living there today. The lot I found is thus probably remnants from a warmer period, or alternatively, they might represent a different species. However, there is no conchological evidence for doubting the species identification! The northernmost find of live caught Dikoleps is a single specimen from Nærøysundet near Rørvik (64 $51^{\prime}$ N, 15-10 m, lots of algae), and from Foldafjorden $\left(64^{\circ} 40^{\prime} \mathrm{N}\right)$, where seven of 15 shells were live caught in a sample from $60-20 \mathrm{~m}$ shell-gravel with lots of hydroid tubes.

Eudaronia aperta (Sykes, 1925) - Described from deep water off Portugal, since found in the Bay of Biscay and off Ireland. Introduced to the Norwegian fauna by Warén (1991), from a single shell from the shelf outside Korsfjorden ( $60^{\circ} 08^{\prime}$ N, 270-250 m). Not in my material.

Lissotesta turrita (Gaglini, 1987) - This species, originally described from 90 m outside Palermo, Sicily, was discovered in Norwegian waters by Warén (1992), from eight specimens and an additional two shells from several samples from the shelf outside Korsfjorden (60 $\left.08^{\prime} \mathrm{N}, 240-330 \mathrm{~m}\right)$. In my material samples from three stations from the outer part of Fanafjorden (180-200 m, 60 13' N, Rhabdammina-sediment, coll. \& leg. A. Warén) contained respectively one, four and 22 specimens of what presumably belong to this species. The specimens are tiny, all less than 0.8 $\mathrm{mm}$ in diameter, thin-shelled, glossy and completely transparent, with three cords around the umbilicus. The protoconch is swollen and with a texture clearly different from the teleoconch. A single, brittle shell from Foldagrunnen in Foldafjorden $\left(64^{\circ} 42^{\prime} \mathrm{N}, 11^{\circ}\right.$ 10 ' E, 200-120 m, coral gravel and clayey silt), probably belongs to the same species.

Palazzia ausonia (Palazzi, 1988) - Described from 500 $\mathrm{m}$ off Liguria, Italy and since redescribed by Warén (1991) who reported it from several localities off western and southwestern Iceland and from three samples from the shelf outside Korsfjorden $\left(60^{\circ} 07^{\prime}\right.$ - 08' N, 285-330 m). Of uncertain systematic affinity, but presumably an archaeogastropod. In my material a single tiny ( $0.7 \mathrm{~mm}$ diam., two whorls) almost planar, specimen from Outer Fanafjorden $\left(60^{\circ} 13^{\prime} \mathrm{N}\right.$, 270-200 m, mud with gravel and lots of Saccammina and Rhabdammina, coll. \& leg. A. Warén). It has about 26 sharp axial ribs fading away on the periphery. Colourless but opaque yellowish because of the soft parts within.

Retigyra millipunctata (Friele, 1886) [= Skenea millipunctata] - This species was last discussed in Warén (1989), in which records from southwest Iceland and 
southeast Greenland were added to the single shell from the slope outside Senja (69 46' N, c. 1190 m). Not in my material.

Rugulina fragilis (G.O. Sars, 1878) [= Trachysma expansa G.O. Sars, 1878] - The nomenclature of this species was exhaustively discussed in Warén (1991). Previously not reported north of Lofoten (G.O. Sars 1878, Warén 1991). In my material two samples from the coral reefs at Steinavær in Andfjorden ( $69^{\circ} 14^{\prime}$ $\mathrm{N}, 285-370 \mathrm{~m}$, moraine and coral rubble), contained two shells and one live caught juvenile. A single specimen, unfortunately with broken outer and lower lip, $1.6 \mathrm{~mm}$ diameter, from Bleiksdjupet, $69^{\circ} 30^{\prime} \mathrm{N}$, $15^{\circ} 46^{\prime}$ E, 500-470 m. Two shells from Ast 78-70 (no distributional information available) might be a further northern distributional extension? The deepest record is a sample of six specimens from $708 \mathrm{~m}$ on the slope just north of the Norwegian Trench $\left(62^{\circ}\right.$ $\left.12^{\prime} \mathrm{N}\right)$. The largest of these six has a frontal diameter of c. $3.8 \mathrm{~mm}$. Also a specimen found by Wikander at Nordleksa in Trondheimsleia, c. $63^{\circ} 35^{\prime} \mathrm{N}$. In addition two samples from the shelf outside Korsfjorden (only dried soft parts remaining), with each three specimens.

Trochaclis islandica Warén, 1989 - The systematics of this species is discussed in Warén (1992). In Warén's description of $T$. islandica, the bulk of his material is from East Greenland and cold, deep water around Iceland. Previously known from Norway from a single shell from outside Korsfjorden $\left(60^{\circ} 07^{\prime} \mathrm{N}\right.$, 300-272 m, sand with foraminifera). In my material a single specimen from the same locality outside Korsfjorden (285-290 m, ooze with sponges, coll. \& leg. A. Warén). The shell is opaque white with two (possibly three) cords inside the umbilicus. The outer lip of the aperture a sloping curve towards the umbilicus. Diameter around $1.5 \mathrm{~mm}$. The present record (if correctly identified) is therefore a confirmation that this species is living on the shelf in western Norway.

*Theodoxus fluviatilis (Linné, 1758) - According to Warén (in Hansson 1998) this fresh- and brackish water species has been recorded from the inner parts of Iddefjorden during the late $19^{\text {th }}$ century. This record might be due to a mix-up of museum labels as never refound in spite of thorough searching (Warén in litt. 2008). All other Scandinavian records are from brackish water in the Baltic and in Öresund, and in fresh water in eastern Sweden. Not in my material and most likely not part of the marine fauna of Norway.
Bittium reticulatum (da Costa, 1778) - Reported from the Norwegian coast north to Trondheimsfjorden $63^{\circ}$ $30^{\prime}$ N (Norman 1902; Sneli \& Gulliksen 2006). This limit has been extended by Brattegard (in Høisæter et al. $1997 \mathrm{a}$ ) to c. $69^{\circ} \mathrm{N}$ (sector 19). It is obviously not uncommon in the Skagerrak area, as Wikander (1989, 1990) reports 17 samples with 39 specimens taken in depths from 4 to $26 \mathrm{~m}$. This shallow water species, usually associated with algae, may occur in enormous quantities on suitable substrates between 0 and $15 \mathrm{~m}$. In my material there is one such mass occurrence in a bay in Fløan (64 30' N), where upwards of 1200 specimens were taken in an epibenthic dredge haul from a soft bottom partly covered with Laminaria saccharina and Corda filum. Further north I have only scattered finds, the northernmost specimens from Bindalsfjorden $\left(65^{\circ} 12^{\prime} \mathrm{N}\right)$. The northernmost shells are from Røssøysund, a narrow sound east of Fugløyfjorden at $67^{\circ} 03^{\prime} \mathrm{N}$. Bittium is apparently never a dominating member of the shell grit in these northern waters, where it is always outnumbered by various species of rissoids and/or pyramidellids.

Turritella communis Risso, 1826 - Recorded north to Lofoten ( $68^{\circ}$ N, G.O. Sars 1878). Very common in the Skagerrak according to Wikander $(1989,1990)$ who lists 77 hauls with anywhere from 1 to 150 specimens in each. In my material no specimens found north of $63^{\circ} 48^{\prime} \mathrm{N}$ where a rich sample of 43 specimens from a mixed bottom with algae at $60-68 \mathrm{~m}$ at the mouth of Valsfjorden were taken. The northernmost shells are from $66^{\circ} 03^{\prime} \mathrm{N}$, and only scattered shells were taken in the intermediate zone. The species appears to be especially numerous in Møre og Romsdal county, where 70 specimens and upwards of 170 shells were sampled from 12 stations. Of these, three samples with from 14 to 32 fully grown specimens, were from 40-60 m depths in fjords with sandy bottoms. The species might be especially bountiful in this region because of a preponderance of sandy bottoms, also in fairly deep fjord basins. Only six specimens from four samples recorded in the Espegrend area.

Marshallora cf. adversa (Montagu, 1803) [= Triphora adversa] - Traditionally all triphorids from North European waters have been named Triphora perversa. In the late 1970's Bouchet \& Guillemot (1978), realised that a suite of species were present in European waters. They described four different species from the French Atlantic coast and at least 17 more from the Mediterranean and Macaronesian biogeographic provinces. As most of these species are almost indistinguishable based on shell morphology alone, a reliable identification should be based on 
the colour pattern of soft parts and/or radula preparations. Such studies have not yet been performed on Norwegian material, but based on extrapolation from the work performed on the French fauna, including material from the southern coasts of Britain, it has been presumed that Marshallora adversa (Montagu, 1803) is the most likely name for the species formerly known as Triphora perversa in Norway. The latter name is today used for a fairly large Mediterranean species (also known from Galicia and the Canaries), transferred to the genus Monophorus. However, the presence of more species in Norway cannot be excluded. The claim of Bouchet \& Guillemot (1978) that the radula illustrated by G.O. Sars (1878) best fits Similiphora similior (Bouchet \& Guillemot, 1978), and not $M$. adversa, indicates that this is a possibility. (The claim of Warén (in Bouchet \& Guillemot 1978 and in Hansson 1998) that the radula illustrated by G.O. Sars is based on material from southern Britain sent to Sars by Jeffreys, needs verification. There is no indication in G.O. Sars (1878) that this is the case).

According to the distributional map in Bouchet \& Guillemot (1978), Cheirodonta pallescens (Jeffreys, 1867 ) is the additional species most likely to be found in Norwegian waters, as this species has been reported from the southern parts of the English Channel, while the other two European Atlantic species is reported to be restricted to the waters south of Brittany in France. In addition a photograph (of 'Triphora perversa' from the Kieler Bay) in Ziegelmeier (1966) is regarded to possibly be of $C$. pallescens. This species should be distinguishable from the other European Atlantic species by the sculpture of the last half whorl where the granular rows divide, and thus five rows should be visible behind the outer lip, as opposed to the three rows of rectangular granules in M. adversa. The protoconchs are indistinguishable in these two species. G.O. Sars (1878) records it from Oslofjorden to 'Ora occident. Norv.' Not mentioned in Wikander (1989, 1990), but 11 specimens and three shells in the material from Skagerrak I received from him. In my material there are 20 specimens and four shells (from 16 samples), all but three from the Espegrend area, most of them from the Hillersholmen locality $\left(60^{\circ} 18^{\prime} \mathrm{N}\right.$, 6-8 $\mathrm{m}$ ). The exceptions are a single and very worn shell without protoconch, from $62^{\circ} 30^{\prime} \mathrm{N}$, and one worn fragment and one well-preserved live-caught specimen from the Herdla area. Most of these are 'typical' M. adversa (sensu Gianuzzi-Savelli et al. 1999), but at least one specimen from Hillersholmen is rather different. This one had a protoconch with larger nucleus and almost no reticulated sculpture on the remaining c. four whorls. The teleoconch whorls increased more rapidly than in the other, mostly strictly conical shells. Except for the protoconch this specimen showed certain similarities to $S$. similior, as described in Bouchet \& Guillemot (1978). The protoconch did not look like any of the species described. The only report I have seen of specimens with severely reduced protoconch sculpture are some Monophorus perversus from Tunisia (Bouchet 1985). Of six specimens from a colony of Filograna growing on the rocky wall at $6 \mathrm{~m}$ in the Hillersholmen sound, only one had an intact protoconch. This was distinctly darker (brown) in colour than the other protoconchs in my material. In addition the double spiral ridge in this specimen was more pronounced than in the others. The whole protoconch was strictly conical, with an acute apex, slowly increasing whorls and with a very shallow suture.

At present too little material is available for naming more than one species from Norway, but I suspect that at least two (more likely three) species are found in our waters. According to Warén (pers. commn) Philippe Bouchet has verified that all the Scandinavian material of Triphoridae in Swedish museums are $M$. adversa.

*Similiphora similior (Bouchet \& Guillemot, 1978) - May be living in Norwegian waters, see Marshallora adversa, above.

Cerithiopsis cf. tubercularis (Montagu, 1803) [= Cerithiopsis tubercularis and Cerithiopsis barleei Jeffreys, 1867] - C. barleei is supposed to be a southern species, which in Britain is only found around the south-western coasts at depths down to $90 \mathrm{~m}$, associated with the sponge Suberites domunculus. $C$. tubercularis is generally supposed to be the only species in Norwegian waters. The diagnostic characters within this genus are not well documented, but usually details of the protoconch are best suited for specific identification. Van Aartsen et al. (1984), Cachia et al. (1996), and Gianuzzi-Savelli et al. (1999) use details of the protoconch for distinguishing between C. barleei and C. tubercularis. The protoconch of C. barleei is rather light-coloured or transparent, slightly cylindrical with one and a half smooth and three ribbed, slightly convex, whorls (SEM-photos in Rodriguez Babio \& Thiriot-Quiévreux 1974, and Gianuzzi-Savelli et al. 1999), while that of C. tubercularis should have four to four and a half smooth, glossy, convex whorls, brown to corneous in colour. The remaining conchological characters seem to be rather diffuse and variable, and not very useful for identification. G.O. Sars (1878) lists C. tubercularis from 'Ora occident. Norv.' only, and Kjell Magne 
Olsen (1994) lists two specimens of C. barleei and four of $C$. tubercularis from Oslofjorden. Wikander (1989) reports two specimens of $C$. tubercularis from Lyngørfjorden (58 $\left.38^{\prime} \mathrm{N}, 09^{\circ} 07^{\prime} \mathrm{E}, 14 \mathrm{~m}\right)$. In the Wikander material from Skagerrak, two shells of what I have preliminarily named $C$. tubercularis and three shells of $C$. 'barleei'. In my material one specimen and one shell from Hillersholmen in Raunefjorden $\left(60^{\circ} 18^{\prime} \mathrm{N}\right)$ were identified as $C$. barleei in 1969. Altogether, my material consists of nine specimens from eight samples all from shallow water in the Espegrend area. One shell from Namsenfjorden $\left(64^{\circ} 26^{\prime} \mathrm{N}, 175-25 \mathrm{~m}\right.$, mixed bottom) and one from Haramsfjorden ( $62^{\circ} 36^{\prime} \mathrm{N}, 30 \mathrm{~m}$, stones and algae) both lost before I was able to verify the identifications. In my nine specimens I seem to recognize three different protoconch types. One, in four specimens, correspond to the SEM-photo of $C$. barleei in Gianuzzi-Savelli et al. (1999), and one, in four specimens, correspond to the SEM-photo of $C$. tubercularis in Gianuzzi-Savelli et al. (1999), while the final one did not fit any of the illustrations for the Mediterranean ones in this book. This latter one, found together with a 'typical' C. tubercularis, may be just an aberrant variant of $C$. tubercularis, with a bigger nucleus than this species, but certain other characters disagree. The whole protoconch is more cylindrical and much more transparent than what is the case for $C$. tubercularis, and the colour of the protoconch is clear brown, as opposed to the more olive brown of 'typical' $C$. tubercularis. The three first teleoconch whorls of this juvenile increase in diameter somewhat faster than the available specimens of C. tubercularis. In addition the aperture appears to be more constricted, with a shorter and less 'backcurved' inner lip, resulting in a smaller aperture overall. The specimen might in fact approach a beginning pupoid shape in many ways, but none of the species described from the Mediterranean are much like. The closest may be the one illustrated as Fig. 55 in Gianuzzi-Savelli et al. (1999), and by them called 'forma nana Jeffreys, 1867'. As pointed out in van Aartsen et al. (1984), Marshall (1978) may have made an unfortunate choice in selecting a lectotype for $C$. tubercularis, as the specimen he picked fits better the description of what is usually taken as $C$. barleei. The genus has not been reviewed recently, and in view of the continued unresolved taxonomy of the European members of the group, I find it best to leave these three 'forms' as Cerithiopsis $\mathrm{sp}(\mathrm{p})$ for the time being.

Cerithiella metula (Lovén, 1846) [including Chasteria danielsseni] - Discussed in Bouchet \& Warén (1993) where Chasteria danielsseni is regarded as a 'deep water' form of $C$. metula. Reported to be found along the whole coast (G.O. Sars 1878). Wikander $(1989,1990)$ reports six samples with 13 specimens taken in depths from 75 to $96 \mathrm{~m}$ in Skagerrak. In my material c. 30 specimens evenly distributed along the coast north to $67^{\circ} 10^{\prime} \mathrm{N}$, but only a single specimen north of that, from $70 \mathrm{~m}$, rocky bottom in Gratangen $\left(68^{\circ} 44^{\prime} \mathrm{N}\right)$. This, the 'typical' form seems to prefer mixed, soft or sandy bottoms at intermediate depths (60-150 m). In the bathyal of the Norwegian Sea, the spiral cords are gradually reduced. Eight specimens from four stations on the slope, from 540 to $1700 \mathrm{~m}$, $62^{\circ} 20^{\prime}$ to $69^{\circ} 21^{\prime} \mathrm{N}$, clearly illustrate this as the spiral sculpture on the shells at the shallowest stations is reduced, while the ones found at the deepest stations are completely devoid of spiral sculpture. (But see Høisæter submitted)

Krachia cossmanni (Dautzenberg \& H. Fischer, 1896) - In Bouchet \& Warén (1993) Warén reports 200 specimens and shells from the shelf outside Korsfjorden, from $240-420 \mathrm{~m}$ depth. The species is conchologically very similar to Cerithiella metula, and is easily confused with that species. The main conchological differences: Krachia has a smaller, less bulbuous protoconch with only a single whorl as against (at least) two whorls, more rapid increase in diameter, more coarse sculpture with far fewer and stronger axial ribs. In my material a single shell from the shelf outside Korsfjorden $\left(60^{\circ} 08^{\prime}\right.$ N, 04 $52^{\prime}$ E, 280-290 $\mathrm{m}$, sand clay tubes and foraminiferans, coll, leg. \& det. A. Warén).

Laeocochlis sinistratus (Nyst, 1835) [= Laeocochlis macandreae (H. Adams, 1858)] - Discussed in Bouchet \& Warén (1993) where the genus name is spelled Laiocochlis. In Opinion 1700 of ICZN, the name is conserved as Laeocochlis. The specific name is sometimes spelled 'sinistrata', but as the genus name is derived from Greek roots, and the Greek noun 'kochlias' is masculine, the correct form is probably 'sinitratus' as used in CLEMAM. The species is stated to be not too uncommon along the whole Norwegian coast south to the westernmost Skagerrak $\left(58^{\circ} \mathrm{N}\right)$ both in the fjords and on the shelf, in 50-700 $\mathrm{m}$, most common in 200-500 $\mathrm{m}$ (Bouchet \& Warén 1993). In my material five specimens and 14 shells. The specimens were all taken on the shelf and in the Norwegian Trench, from $61^{\circ}$ to $62^{\circ} 30^{\prime} \mathrm{N}$, between 300 and $500 \mathrm{~m}$. The shells were rather evenly distributed on the sectors north to $69^{\circ} 14^{\prime} \mathrm{N}$. 
Eumetula arctica (Mørch, 1857) - According to Bouchet \& Warén (1993) distributed along the whole coast south to and well into Skagerrak, in 100-500 m. According to G.O. Sars (1878) it should be present in Oslofjorden and on the western and northern coasts, but not on the south coast of Norway ('Ora meridion. Norv.'). Not mentioned in Wikander $(1989,1990)$. In my material only 11 specimens of which the northernmost was from Gratangen, $68^{\circ} 42^{\prime} \mathrm{N}$, rocky bottom at 100-125 $\mathrm{m}$. The deepest was from a locality on the shelf/slope break at $543 \mathrm{~m}$, just north of the Norwegian Trench, where six specimens were found. Shells were moderately common however, (altogether 170 shells) most of them found between $64^{\circ} 25^{\prime}$ and $65^{\circ} 10^{\prime} \mathrm{N}$.

Eumetula n.sp. - Six shells from two stations on the upper slope just north of the Norwegian Trench $\left(62^{\circ} 30^{\prime} \mathrm{N}\right.$, 602 and $604 \mathrm{~m}$ ), as well as one from the basin of the Iceland Sea east of the Kolbeinsey Ridge (68 $54^{\prime} \mathrm{N}$, $14^{\circ} 14^{\prime} \mathrm{N}, 1590 \mathrm{~m},-0.9^{\circ} \mathrm{C}$, coll. \& leg. J.-A. Sneli), has a habitus different from all the photographs in Bouchet \& Warén (1993), and may represent an undescribed species. The whorls are very convex with deep sutures, and there is a strong spiral cord just above the suture, best seen on the body whorl, otherwise partly concealed by the suture. Three evenly spaced minispirals visible with good lighting between the sharp axial ribs. Additional microscopic spirals scattered throughout the spaces between ribs. The protoconch is bulbuous and at least as large as in C. metula, but with (apparently) only $21 / 2$ whorls.

Aclis ascaris (Turton, 1819) - This small, southern species has only been reported a few times from Norwegian waters. Jeffreys (1867) cited Lovén as having found it near Bergen, and G.O. Sars (1878) reported it from the west and south coast of Norway. Not mentioned by Friele $(1874,1876)$ or Norman (1879). Suggested by Warén (in Hansson 1998) as possibly being the male of $A$. minor. In the Wikander material from Skagerrak at least 6 specimens from several stations. Not in my material from the west or north coast.

Aclis minor (Brown, 1827) - This species is larger than $A$. ascaris, and has a much wider and more prominent umbilicus. The spiral sculpture, although variable is usually rougher and more prominent, and the whorls appear on the whole less polished. The protoconch is pointed, even more so than in A. walleri, and the diameter is much the same for both species, but $A$. minor seems to have a somewhat longer and narrower, almost cylindrical, smooth protoconch than $A$. ascaris although both are of some three 1/2 whorls. Suggested by Warén (in Hansson 1998) as possibly being the female of $A$. ascaris. It is reported somewhat more frequently from Norwegian waters than A. ascaris. G.O. Sars (1878) listed it from both the west and south coast as well as from Oslofjorden. In Wikander $(1989,1990)$ three specimens from three different samples from 17 to $112 \mathrm{~m}$ are listed with a query from between Lillesand and Arendal. In the Wikander material from Skagerrak at least three specimens from several stations. Not in my material from the west or north coast.

Aclis sarsi Dautzenberg \& H. Fischer, 1912 - Discussed by Bouchet \& Warén (1986). Probably represented by a small, very narrow form, and a larger, more conical form (perhaps sex dimorphism, see Warén in Bouchet \& Warén 1986). Reported from various localities around the coast and in the fjords from the southern Barents Sea $\left(70^{\circ} 55^{\prime} \mathrm{N}, 18^{\circ} 38^{\prime} \mathrm{E}\right)$ to Oslofjorden (G.O. Sars 1878; Bouchet \& Warén 1986), usually between 100 and $500 \mathrm{~m}$. In my material 14 samples, three specimens in two samples, and some 25 shells in 12 samples. Most of these belong to the 'large' variety, but at least three well preserved short, narrow forms obviously belong to the 'small' form, e.g. a specimen in a sample from outer Fanafjorden $\left(60^{\circ} 13^{\prime}\right.$ N, 180$190 \mathrm{~m}$, fine sediment with lots of foraminiferans, coll. \& leg. A. Warén). The northernmost find is two shells from the slope station, Bleiksdjupet (just NW of Andøya 700-200 m), and the rest are fairly evenly divided between the four sections of the coast from Bodø to the Espegrend area. Usually it is not hard to distinguish the 'small' from the 'large' form, as small shells of the 'large' form are more conical than equally sized 'small' forms, and these latter shells tend to have a flaring outer lip at a length of around two mm. Sometimes the two forms occur together (in a sample from near Bodø, in the Wikander material, one 'large' and one 'small' specimen, together with 10 'small' and 13 'large' shells were found), but mostly a sample consists of only 'large' forms, e.g. a sample from north of Kristiansund ( $63^{\circ} 10^{\prime}$ N, 145 m, sand), with 6 worn shells. At least the shape and size of the protoconch indicates that these two forms are conspecific, although it cannot be excluded that two species are involved. A sample from Breisunddjupet $\left(62^{\circ} 30^{\prime} \mathrm{N}, 120\right.$ to $60 \mathrm{~m}$, a very rich shell-sand station), contains three well preserved specimens, the largest $6.1 \mathrm{~mm}$. with typical 'aclidid' shape of the aperture, with the outer lip flaring, and with weak cords circling the whorls (on the body whorl at least eight, of which the five lower ones are close together and below the periphery). Such 'cords' are supposed to be characteristic for A. ascaris and A. minor, but these are stated to have protoconchs of four whorls 
(no information on the diameter of the nucleus, however).

Aclis walleri Jeffreys, 1867 [= Aclis walleri (Jeffreys, 1867)] - This species is easily distinguished from A. sarsi by its very acute and narrow protoconch of three $1 / 2$ whorls. Reported from the Norwegian coast from Lofoten (G.O. Sars 1878) and the Bergen area (Bouchet \& Warén 1986). Earlier records (as A. exigua G.O. Sars, 1878) are not reliable, as it was often confused with $A$. sarsi. In my material a sample from $87 \mathrm{~m}$ at the Sleipner field in the North Sea with nine specimens of which eight are juveniles w/small but distinct eyes placed far apart. From the Norwegian coast five samples with a total of 6 shells. These are: one shell from outer Fanafjorden, same sample as the specimen of $A$. sarsi mentioned above, a broken one from Breisunddjupet ( $62^{\circ} 27^{\prime} \mathrm{N}, 245 \mathrm{~m}$ ), a large, very well conserved shell from Talgsjøen $\left(63^{\circ}\right.$ $10^{\prime} \mathrm{N}, 120-80 \mathrm{~m}$, stones and sand), finally a smaller shell from Tomfjorden $\left(66^{\circ} 15^{\prime} \mathrm{N}, 380-300 \mathrm{~m}\right.$, mixed bottom substrate). Based on my material it is apparently less common than $A$. sarsi.

Epitonium clathratulum (Kanmacher, 1798) - The presence in Norwegian waters of this southern species, in British waters mainly known from the south west coast (Graham 1988), is poorly documented. Jeffreys (1867) mentions only a single record from north of the Brith Isles, viz. in Bohuslän where it had been dredged by Malm from 70 fathoms. Not mentioned by G.O. Sars (1878), but recently Wikander (1990) found two specimens in the Norwegian Skagerrak area, just south of Arendal $\left(58^{\circ} 20^{\prime} \mathrm{N}, 140\right.$ and $112 \mathrm{~m}$ respectively). Not in my material.

Epitonium clathrus (Linné, 1758) - A southern, shallow water species, in the second half of the $19^{\text {th }}$ century reported from around Bergen (Friele 1874; Norman 1879). By G.O. Sars (1878) recorded from Oslofjorden, the south coast and the west coast. Later recorded from Hardangerfjorden (Grieg 1914). In my material one fresh looking shell, fully grown, from Rongesundet $\left(60^{\circ} 29^{\prime} \mathrm{N}, 30-10 \mathrm{~m}\right.$, shell gravel with shells of Arctica islandica and Modiolus modiolus, many colonies of Alcyonium). In addition a shell from an unspecified locality in the Espegrend area from 1987. A single worn fragment of the upper c. four whorls, from Tomfjorden $\left(66^{\circ} 15^{\prime} \mathrm{N}, 380-300 \mathrm{~m}\right.$, mixed bottom) fits this species better than any other. If correct, this is an extension of the northern limit of almost 6 degrees of latitude!
Epitonium greenlandicum (Perry, 1811) - According to Bouchet \& Warén (1986) distributed along the entire Norwegian coast south to and including Oslofjorden. However G.O. Sars (1878) and Wikander $(1989,1990)$ did not find it in the Skagerrak area. In my material nine specimens and 32 shells, the northernmost is six specimens from Varangerfjorden, between Ekkerøya and Bøkfjorden $\left(69^{\circ} 58^{\prime} \mathrm{N}, 305 \mathrm{~m}\right.$, mixed muddy bottom with Rhabdammina foraminiferans), and the southernmost two specimens from the Espegrend area. More common on the northern part of the coast.

Epitonium trevelyanum (Johnston, 1841) - A southern species sparingly found on the Norwegian coast north to the Bergen area (Jeffreys 1870; G.O. Sars 1878). Wikander $(1989,1990)$ reports eight samples with one specimen in each taken in depths from 25 to 130 $m$ on the Skagerrak coast. In my material four shells from the southern part of the area, the northernmost from Talgsjøen $\left(63^{\circ} 10^{\prime} \mathrm{N}, 120-80 \mathrm{~m}\right.$, sandy mixed bottom). In addition 14 specimens from two samples from the North Sea $\left(58^{\circ} 30^{\prime} \mathrm{N}\right.$ at $87 \mathrm{~m}$, and $60^{\circ} 35^{\prime}$ $\mathrm{N}$ at $106 \mathrm{~m}$ ).

Epitonium turtonis (Turton, 1819) - A southern, shallow water species even less common on the Norwegian coast than E. trevelyanum. All Norwegian records seem to be from the middle to late 19th century, from Oslofjorden, the south and the west coast (G.O. Sars 1878). Not mentioned in Wikander $(1989,1990)$. Not in my material.

Acirsa coarctata (Jeffreys, 1884) [= Pseudacirsa coarctatum] - This species has only been recorded from northern Norway, from Tromsø north and east to Vadsø in depths from 70 to $300 \mathrm{~m}$, and in fish (haddock) stomachs (Schneider 1897 and Bouchet \& Warén 1986). Not in my material.

Gregorioiscala sarsi (Kobelt, 1904) [= Pseudacirsa sarsii (Kobelt, 1905)] - According to Bouchet \& Warén (1986) only known from one specimen and two shells, of which the holotype was taken by G.O. Sars (1878) (who referred it to Scalaria varicosa S.V. Wood, 1842) at 180-170 $\mathrm{m}$ on the Norwegian west coast outside Måløy $\left(61^{\circ} 55^{\prime} \mathrm{N}\right)$. The two shells are from deep water at respectively $38^{\circ}$ and $48^{\circ} \mathrm{N}$. Not in my material.

EULIMIDAE - This group is one of the taxonomically more complex of all the groups included in this compilation, and the treatment below is far from exhaustive. Except for some rather distinctive species the names 
used below must be considered as preliminary, and I find it highly likely that in a future revision, several additional species will be included.

Eulima bilineata Alder, 1848 - This is one of the most frequently encountered eulimids in Norwegian waters, found north to Hammerfest, $70^{\circ} 30^{\prime} \mathrm{N}$ (G.O. Sars 1878), by Norman (1902) reported also from the entrance to Vadsø harbour in Varangerfjorden. Wikander $(1989,1990)$ reports five samples with 11specimens taken in depths of 60 to $95 \mathrm{~m}$ on the Skagerrak coast. In my material altogether 80 specimens and an additional 320 shells. North of Lofoten I have only shells (none from East Finnmark), but a number of specimens from the area outside and just south of Bodø (around $67^{\circ} \mathrm{N}$ ) where it occurred in eight samples. A further series of 14 specimens and 11 shells from the area north of Bodø in the Wikander material. In the Wikander material also 6 specimens and three shells from the Skagerrak coast.

Eulima n.sp. - A few samples of Eulima 'bilineata' in the Wikander material from the Bodø region in Nordland, contain a number of rather thin-shelled specimens with unusually large protoconch and an aperture with a shape diverging from E. bilineata s.str. These might be members of an undescribed species. Several samples from my Nordland material apparently contain empty shells of both forms. Most potential shell characters are rather elusive, and it is impossible at this stage to safely classify all shells.

Bathycrinicola curta (Warén, 1972) [= Melanella curta] - Conical with unusually wide aperture, c. three mm long. Only known from the shelf outside Korsfjorden and Trondheimsfjorden, 275-325 m (Bouchet \& Warén 1986). In my material, a single shell from the shelf outside Korsfjorden, $\left(60^{\circ} 08^{\prime} \mathrm{N}, 4^{\circ} 50^{\prime} \mathrm{E}, 330\right.$ $322 \mathrm{~m}$, sand with some sponges and ascidians, coll., leg. \& det, A. Warén).

Crinolamia dahli Bouchet \& Warén, 1979 - Looks like an inflated Hemiaclis ventrosa, animal without eyes. Known from the holotype and 20 paratypes and apparently (Bouchet \& Warén 1986) not reported since the description. According to Bouchet \& Warén (1986) confined to the abyssal parts of the Norwegian Sea. In my material two specimens, one almost five $\mathrm{mm}$ long and $2.5 \mathrm{~mm}$ diam., from the slope at $62^{\circ} 25^{\prime}$ $\mathrm{N}\left(501 \mathrm{~m},+2.9^{\circ} \mathrm{C}\right)$. The other from $3000 \mathrm{~m}$ at $64.5^{\circ}$ $\mathrm{N}$. A few specimens also found in material from the slope around $69^{\circ} \mathrm{N}$, and kept in the Museum of Natural History and Archeology (NTNU).
Curveulima macrophthalmica (Warén, 1972) [= Polygireulima macrophthalmica] - Somewhat irregularly curved shell-axis, large protoconch with four whorls, high, straight aperture. Max length c. $7.5 \mathrm{~mm}$ (Bouchet \& Warén 1986, Warén 1991). In Norway known from Korsfjorden, Trondheimsfjorden and Lofoten, 50-200 m, possibly a parasite on Hathrometra (Bouchet \& Warén 1986). In my material two specimens and two shells from three samples in the fjords just outside and north of Molde (around $62^{\circ} 45^{\prime} \mathrm{N}$ ), and one specimen from $300 \mathrm{~m}$ in the Norwegian Trench, outside Fensfjorden. Between 5.2 and 5.6 $\mathrm{mm}$ long (aperture c. $1.6 \mathrm{~mm}$ ).

Enteroxenos oestergreni Bonnevie, 1902 - This internal parasite of aspidochirote holothurians is, according to Lützen (1979), common north to $70^{\circ} 30^{\prime} \mathrm{N}$. In my material, 101 specimens of Stichopus tremulus from a single station, Linesfjorden in Sør-Trøndelag $\left(63^{\circ}\right.$ 59' N, 200-238 m, soft bottom) were checked for parasites. Six holothurians turned out to be infected. No attempts were made to follow this up on other stations.

*Entocolax sp. - May be living in western Norway. "Two females of a species possibly referable to Entocolax were found (by AW) free in a dredge-haul from 700 $\mathrm{m}$ in Korsfjorden (W Norway [c. $60^{\circ} 11^{\prime} \mathrm{N}$ ] where also some fragments of Myriotrochus vitreus (M. Sars) were found, ..." (Bouchet \& Warén 1986). Not in my material.

Haliella stenostoma (Jeffreys, 1858) - A common soft bottom species, easily recognized from its large protoconch and convex whorls. Reported to be common near Tromsø (c. $69^{\circ} 41^{\prime} \mathrm{N}$ ), but not observed further north (Schneider 1886). G.O. Sars (1878) reports it as everywhere rare in southern Norway, but Wikander $(1989,1990)$ found 11 specimens in five samples from 30 to $155 \mathrm{~m}$ on the Skagerrak coast. In my material altogether 56 specimens and an additional 70 shells, the northernmost five specimens from three stations in Grovfjord ( $68^{\circ} 42^{\prime} / 43^{\prime} \mathrm{N}, 200-320 \mathrm{~m}$, very soft bottom), while I found eight specimens in the Espegrend area, and 11 in Møre og Romsdal county.

Halielloides nitidus (Verrill, 1884) [= Haliella martynjordani (Jordan, 1895)] - The Norwegian material was described as Halielloides ingolfiana by Bouchet \& Warén in 1986, but this name was recognized as a synonym of $H$. nitida by Warén (1991). According to Clemam the correct spelling should be $H$. nitidus. According to Bouchet \& Warén (1986) in Norwegian waters found off Hammerfest $\left(70^{\circ} 40^{\prime} \mathrm{N}\right)$ and outside 
northern Norway at 130-200 m, without further specification, as well as in Trondheimsfjorden (six specimens). Not in my material except for an empty, fragile shell (unfortunately destroyed during handling) from the slope NW of Kvaløya in Troms $\left(70^{\circ}\right.$ $12^{\prime} \mathrm{N}, 17^{\circ} 01^{\prime}$ E, $870 \mathrm{~m}$, coll. \& leg. J.-A. Sneli).

Hemiaclis ventrosus (Friele, 1876) [= Hemiaclis glabra G.O. Sars, 1878 and Hemiaclis ventrosa (Friele, 1876 ex Jeffreys MS)] - In Clemam this species is incorrectly attributed to Friele (1874). Actually the description in Friele (1876) was based on specimens from Lofoten collected by G.O. Sars, and the name was suggested by Jeffreys. Illustrated and discussed in Bouchet \& Warén (1986), who also are responsible for synonymizing $H$. glabra with $H$. ventrosa. By these authors recorded from the outer shelf and upper slope from c. $60^{\circ} 10^{\prime} \mathrm{N}$ and northwards to the southern Barents Sea at $71^{\circ}$ N, from c. 600 to 195 $\mathrm{m}$. In my material seven samples, two from NordTrøndelag, three from Nordland, and two from the Andfjorden area, with altogether 15 shells. Only one specimen, from the sound between Leirfjorden and Vefsnfjorden, rather far from the outer coast $\left(66^{\circ} \mathrm{N}\right.$, 120-140 m, gravel and coarse sand). The southernmost records in my material are two shells from two localities just outside Namsenfjorden (c. $64^{\circ} 36^{\prime} \mathrm{N}$, 230-40 m, Lophelia rubble and gravel).

Melanella spp. - This is a diverse and confusing genus, still not satisfactorily reviewed. Some of the identifications in the following are prelimnary.

Melanella alba (da Costa, 1778) - By far the largest North European species in this genus, max. length around $20 \mathrm{~mm}$, and not possible to confuse with any other. Illustrated in Warén (1988), and neotype selected and described in detail in Warén (1989b). A species with a predominantly southern distribution, reasonably common in British waters. Earlier records from Norway are few, listed (as Eulima polita) in Nordgaard (1913). The northernmost of these records appears to be from the sound between Kinn and Reksta outside Florø $\left(61^{\circ}\right.$ $35^{\prime} \mathrm{N}, 55 \mathrm{~m}$, shell sand), taken by Friele \& Hansen in 1875. In my material, a single sample containing 11 specimens, from Solsviksundet (c. $60^{\circ} 26^{\prime} \mathrm{N}, 15 \mathrm{~m}$, 'clean' shell sand, collected in 1965). Not refound in the Espegrend area, but a sample from Edøyfjorden northeast of Kristiansund (63 $15^{\prime} \mathrm{N}, 07^{\circ} 55^{\prime} \mathrm{E}, 40 \mathrm{~m}$, rocky bottom, NTNU-coll.) contained two specimens and four shells.

Melanella frielei (Jordan, 1895) - A little smaller (Bouchet \& Warén (1986) picture a specimen of $9.2 \mathrm{~mm}$ ) and narrower than M. lubrica and not quite as polished. Completely straight length axis, yellow to orange soft parts, with blotches of brownish red (in ethanol-preserved specimens). According to Bouchet \& Warén (1986:362 and Figs 848-852) mature males are much smaller than females, and the shell shows some confusing ontogenetic changes. Supposed by Warén to be a host-specific parasite of Mesothuria intestinalis, at least in Norwegian waters, and depth distribution should thus follow that species. Fairly common in the fjords and along the upper part of the slope along the whole Norwegian coast, from c. 30 to $700 \mathrm{~m}$ (Bouchet \& Warén 1986). Wikander (1990) reports a single specimen from $65 \mathrm{~m}$ at the bottom of Stolsfjorden outside Flekkefjord ( $6^{\circ} 41^{\prime}$ E). In my material (with reservation) 63 specimens from 32 stations, the northernmost from Grovfjord and Gratangen ( $68^{\circ} 44^{\prime} \mathrm{N}$, fjord bottoms down to $325 \mathrm{~m}$, mostly soft bottom) and with increasing frequency southwards to the Espegrend area, where 23 specimens were found.

Melanella laurae (Friele, 1886) - According to Bouchet \& Warén (1986) and Warén 1993 only known from the type material (five syntypes from the slope, 1187 m, outside Malangen in Troms county, at $69^{\circ} 46^{\prime} \mathrm{N}$ ) and two records from the deeper part of the FaroeShetland channel. In my material a single specimen from $1340 \mathrm{~m}$ in the middle part of the Faroe-Shetland channel.

Melanella lubrica (Monterosato, 1890) [= Melanella lubrica (Monterosato, 1891)] - Species of intermediate size, the second largest in our waters, according to Graham (1988) reaching $9 \mathrm{~mm}$, but I have at least one specimen c. $10.5 \mathrm{~mm}$ long. Very weakly curved length axis, wide but not particularly high aperture, yellowish white soft parts, relatively acute protoconch (somewhat more acute than in M. frielei). A species with a predominantly southern distribution, but reasonably common in comparatively shallow (down to at least $100 \mathrm{~m}$ ) waters in Norway. In older literature often recorded as Eulima intermedia Cantraine, but this name just as often used for $M$. frielei. Wikander (1990) reports seven samples with one specimen each, from 25 to $79 \mathrm{~m}$ on the Skagerrak coast. In my material 67 specimens from 16 samples, the large majority from the Espegrend area. In a single recent (2007) sample no less than 20 specimens. Only four specimens from Møre og Romsdal, two specimens from Frenefjorden $\left(62^{\circ} 50^{\prime} \mathrm{N}, 62-50 \mathrm{~m}\right.$, sand) are the northernmost records so far. Further north only a few empty shells, the northernmost from $66^{\circ} \mathrm{N}$, and that one is questionable. Two shells from Lamholmen out- 
side Gjerdingen ( $64^{\circ} 58^{\prime} \mathrm{N}, 80-30 \mathrm{~m}$, shell grit) may be more reliable as a northern distributional limit.

Melanella monterosatoi (Monterosato, 1890) [= Polygireulima monterosatoi] - Here used as name for the fourth largest species (after M. alba, M. lubrica og M. frielei) in Norwegian waters. Weakly curved length axis, acute protoconch (appreciably more acute than in M. frielei, and also more acute than $M$. lubrica), narrow aperture almost without outer lip curvature. Wikander (1990) records three samples with one specimen in each from 40 to $130 \mathrm{~m}$ on the Skagerrak coast. Soft parts yellowish white, weakly greenish (in ethanol-preserved material), with large, well separated eyes. In my material 42 specimens, mostly from the Espegrend area, nine from Møre og Romsdal. Many specimens and shells intermediate with what I have called $M$. cf. polita below.

Melanella orphanensis Clarke, $1974[=$ M. platyacme sensu Hubendick \& Warén 1973] - According to Bouchet \& Warén (1986) found at 250-280 m outside Lødingen in Vestfjorden c. $68^{\circ} 22^{\prime} \mathrm{N}$, and in several samples from Trondheimsfjorden (c. $63^{\circ} 30^{\prime} \mathrm{N}$ ) at moderate depths (one sample from 35-45 m). The type material is from the western Atlantic, at $50^{\circ} 30^{\prime}$ $\mathrm{N}, 1750 \mathrm{~m}$. Not in my material.

Melanella cf. polita (Linné, 1758) [= Polygireulima monterosatoi in part and P. sinuosa (Scacchi, 1836)] - Identification of the smaller species of Melanella is not straightforward, and it is still uncertain whether the Mediterranean M. polita (with a neotype designated by Warén (1988) from Tunisia) is the same as our North European species, reported (in Hansson 1998) to be found from Øresund via Bohuslän north to $61^{\circ} 30^{\prime} \mathrm{N}$ on the Norwegian coast. As to the possible presence in my material see $M$. monterosatoi above. A specimen from Liholmsrennen $\left(60^{\circ} 18^{\prime}\right.$ N) from Sept. 2007 photographed alive, is profusely speckled with bright red pigment (visible through shell) dorsally on body whorl, and with large eyes. Two photographs of living Mediterranean specimens in Gianuzzi-Savelli et al. (1999) display more or less the same colour pattern.

Melanella turrita Bouchet \& Warén, 1986 - Only known from the holotype, from $63^{\circ}-64^{\circ} \mathrm{N}$ outside the Norwegian coast at 200-400 m. Not in my material, but a specimen showing many of the characteristics of this species, except for the presence of eyes and a somewat more elongated aperture was found at the shelf/slope 'transition' station $(540 \mathrm{~m})$ just north of the Norwegian Trench.
Pelseneeria stylifera (Turton, 1825) $[=$ Pelseneeria stylifera (Turton, 1826)] - This southern species, an external parasite of Echinus, has been reported from western Norway (Friele 1874) and Oslofjorden (G.O. Sars 1878). In my material only a sample from the Norwegian sector (Ekofisk) of the North Sea (coll \& leg. V. Eriksen).

Vitreolina n. spp. [= Vitreolina philippii (Rayneval \& Ponzi, 1854)] - Probably a mixture of several species, probably all undescribed. Impossible to distinguish with certainty when only shells are available. Somewhat easier with preserved specimens, but ideally living animals should be studied. Several of the forms occur in abundance in their preferred habitats. From the Skagerrak coast Wikander $(1989,1990)$ reports 38 samples with from one to 18 specimens in each, from 8 to $130 \mathrm{~m}$, no doubt including several species. In my material more than 1420 specimens, of which 1320 from the Espegrend area. In the material from Hillersholmen $\left(60^{\circ} 18^{\prime} \mathrm{N}\right)$ I have samples with from 100 to 230 specimens in each.

Littorina spp. - The European species of Littorina have been extensively revised by Reid (1996), and I just reiterate his main distributional data below.

Littorina arcana Hannaford Ellis, 1978 [= Littorina arcana Hanaford Ellis, 1978] - According to Reid (1996) in Norway only recorded from eight localities from Trondheimsfjorden and northwards to East Finnmark. Outside Norway only recorded from the British Isles and Brittany in France. The few shells potentially present in my material are not distinguished from $L$. saxatilis (see below). However, a small sample (including four newly settled larvae) from Valsfjorden, Gjelsvik (63 49’ N, 2 m, Zostera 'meadow' on fine sand) might fit the description of L. arcana.

Littorina compressa Jeffreys, 1865 [= Littorina saxatilis (Olivi, 1792) in part] - This species is very sparsely distributed in northern Norway from Narvik and northwards (in addition to its main distribution in the British Isles and Brittany), and according to Reid (1996) it may safely be assumed that it is absent from the coast of Norway south of Narvik. In my material it is not distinguished from L. saxatilis (see below).

Littorina fabalis (Turton, 1825) [= Littorina mariae Sacchi \& Rastelli, 1966] - Reported along the entire Norwegian coast by Reid (1996). Found sympatrically with $L$. obtusata on fucoid algae, but usually most abundant lower on the shore, in the Fucus serratus 
zone. In my material it is not distinguished from $L$. obtusata (see below).

Littorina littorea (Linné, 1758) - Found abundantly in the intertidal along the whole coast (G.O. Sars 1878, Reid 1996). Wikander $(1989,1990)$ reports 16 samples with altogether 120 specimens at various localities from 1 to $65 \mathrm{~m}$ depth on the Skagerrak coast. In my material only occasional specimens. A couple of shallow water stations around $64^{\circ} 30^{\prime} \mathrm{N}$ with high numbers, otherwise only three specimens from each of two stations in the Andfjorden-Gratangen area, respectively $69^{\circ} 16^{\prime} \mathrm{N}$, and $68^{\circ} 41^{\prime} \mathrm{N}$. Also three samples of shells from East Finnmark, one from Bugøyfjord (coll. \& leg. T.E. Lein) containing some 20 large shells, between 30 and $40 \mathrm{~mm}$ high.

Littorina obtusata (Linné, 1758) [including Littorina palliata (Say, 1822)] - Common along the whole coast (Reid 1996). Found sympatrically with L. fabalis on fucoid algae, but usually most abundant higher in the littoral, on Fucus vesiculosus and Ascophyllum nodosum. My material is probably a mixture of L. obtusata and L. fabalis. Very little material preserved, and no attempts to distinguish between the two.

Littorina saxatilis (Olivi, 1792) - L. saxatilis s. str. is present in the upper littoral along the whole coast (Reid 1996). Samples of L. rudis, L. neglecta and L. arcana identified by Peter van Marion are included in the collection. Of these, L. arcana is recognised as a valid species (see above), L. neglecta is a 'barnacle' form of $L$. saxatilis, while $L$. rudis is a strict synonym of L. saxatilis. In my material altogether 141 specimens of what has been classified as L. saxatilis from every part of the coast from Espegrend and northwards. However, no attempts have been made to distinguish between the 'sibling' species of L. saxatilis s.l.

Melarhaphe neritoides (Linné, 1758) [= Littorina neritoides] - This species, confined to the supralittoral on the most exposed rocky coasts, has been recorded only from the area between Hardangerfjorden and Sognefjorden in Norway (Lewis \& Tambs-Lyche 1962, Brattegard in Høisæter et al. 1997a, in the latter is included a record from Oslofjorden). In my material around 50 specimens from the supralittoral on islets outside Sotra $\left(60^{\circ} 12^{\prime} \mathrm{N}\right)$ and the island One in Øygarden $\left(60^{\circ} 32^{\prime} \mathrm{N}\right)$, all from the supralittoral. Never searched for during the summer cruises.

Lacuna crassior (Montagu, 1803) - This species has only been found in Norwegian waters in Porsangerfjorden and Øksfjorden (Warén in litt, 2008). Its reported distribution is unusual, mainly Arctic, but also found, if uncommon, on soft bottoms down to c. $90 \mathrm{~m}$ off the coast of Ireland and Britain as well as northern France (Graham 1988). It has also been found in shallow water in the Faroes. In Friele \& Grieg (1901) a well preserved shell was reported from an abyssal (2440 m) station just west of Spitsbergen. Friele \& Grieg's interpretation is that it had been brought out with drift ice. Not in my material.

Lacuna pallidula (da Costa, 1778) - A common species on algae, in Norway especially Fucus serratus. Reported by G.O. Sars (1878) to be not uncommon along the whole coast (including East Finnmark). Wikander (1989) records four specimens from a single sample from $12 \mathrm{~m}$ on the Skagerrak coast. Apparently more common in the north than on the west or south coast, as Schneider (1886) reports it to be abundant on fucoid algae in Kjosen, an arm of Ullsfjorden $\left(69^{\circ} 35^{\prime} \mathrm{N}\right)$. In my material 21 specimens, 10 from the Espegrend area, 10 from around $64^{\circ} 30^{\prime} \mathrm{N}$, and one from around $66^{\circ} \mathrm{N}$. In the extensive study of Laminaria hyperborea stipes (with epiflora) from Lyroddane $\left(60^{\circ} 10^{\prime} \mathrm{N}\right)$ only three specimens of $L$. pallidula were reported, as opposed to more than 8000 specimens of Lacuna vincta. Recently (September/October 2008) washing of $F$. serratus from the littoral at Rong in Øygarden $\left(60^{\circ} 29.5^{\prime} \mathrm{N}\right)$ produced 25 specimens, and a sample of Palmaria palmata from the same locality yielded eight specimens of what is presumably this species. Soft part colour patterns and some peculiarities in shell morphology indicate that two sympatric species may be involved.

Lacuna parva (da Costa, 1778) - According to G.O. Sars (1878) found on the western and southern coasts of Norway. Wikander $(1989,1990)$ found 10 specimens in five samples from 7 to $18 \mathrm{~m}$ on the Skagerrak coast. Reported by Brattegard (in Høisæter et al. 1997a) from seven localities between eastern Skagerrak and Julsundet (between Aukra and the mainland, $62^{\circ} 51^{\prime}$ $\mathrm{N}$, see Sneli 1974). In my material a single rather old and worn shell c. $4 \mathrm{~mm}$ diam., from Sængsbukten, Korsfjorden ( $60^{\circ} 08.5^{\prime}$ N, 300-200 m, dredge-haul up the steep rocky slope with pockets of shell gravel).

Lacuna vincta (Montagu, 1803) - An abundant species on algae, especially kelp, along the whole coast in the upper sublittoral (e.g. G.O. Sars 1878). Wikander $(1989,1990)$ reports 25 samples with a total of more than 1000 specimens from the Skagerrak coast. In my material close to 10000 specimens distributed among all the sectors, although only empty shells from East Finnmark. An important component of the 
shell grit at least north to $69^{\circ} \mathrm{N}$.

Skeneopsis planorbis (O. Fabricius, 1780) - According to G.O. Sars (1878) common along the whole coast, including East Finnmark, but not mentioned in Wikander (1989, 1990). In my material, several large samples containing altogether 1170 specimens. Most abundant in a sample from Stamnes in NordTrøndelag (64 $30^{\circ} \mathrm{N}, 0$ to $0.5 \mathrm{~m}$, fine sand with mud and Fucus) with 636 specimens. Further north, one sample with 56 specimens from East Finnmark in the middle of Kjøfjorden ( $69^{\circ} 48^{\prime} \mathrm{N}$, littoral). In Sjonafjorden ( $66^{\circ} 17^{\prime} \mathrm{N}, 160-80 \mathrm{~m}$, shell sand) a sample had around 50 shells, competing with Lacuna vincta and three rissoids as being the dominant member in the shell grit.

Rissoa spp. - The north-European species of Rissoa and Pusillina have been revised fairly recently by Warén (1996b), and the notes below lean heavily on his revision, although still a lot is unresolved concerning this group of species.

Rissoa lilacina Récluz, 1843 [= Rissoa rufilabrum (Alder, 1844) and Rissoa porifera Lovén, 1846] - The two forms listed as valid species in Høisæter (1986) are regarded by CLEMAM as the two northernmost of several partly geographically separated forms of $R$. lilacina. The distribution is stated to be from Lofoten (ca. $68^{\circ} \mathrm{N}$, where G.O. Sars (1878) found it to be very rare), and southwards to southern Kattegat (Warén 1996b). Schneider (1886) reported a single shell from Tromsøysundet (c. $69^{\circ} 42^{\prime} \mathrm{N}$ ). Wikander $(1989,1990)$ reported it (under three different names) in 25 samples with a total of more than 300 specimens from the Skagerrak coast. In my material three specimens from Outer Kvæfjorden (68 $50^{\circ} \mathrm{N}$, 18-25 m, Lithothamnion zone with algae), plus shells from two other stations in the same area. That only a single shell was found in the series from Nordland may be because few suitable habitats were sampled. In the series from Nord-Trøndelag, I have seven specimens in altogether five samples. A total of three specimens and three shells from the series from Møre og Romsdal, and ten specimens from the Espegrend area. In a sample from 2007 (Hillersholmen, 60 18' $\mathrm{N}, 7-9 \mathrm{~m}$ ) two specimens were found, one attributable to the form $R$. rufilabrum and one to $R$. porifera, both very characteristic and distinctly different.

Rissoa membranacea (J. Adams, 1800) - There is still no general agreement on whether the planktotrophic form, R. labiosa (Montagu, 1803) and the lecithotrophic form, $R$. membrancea s.str. are two different species, or ecotypes of the same species (see Warén 1996b). However CLEMAM accepts them as synonyms. If they are kept apart, the Norwegian form should probably be called R. labiosa. According to G.O. Sars (1878) this shallow water species (as Rissostomia octona, Lin.) is found only in Oslofjorden and (as Rissostomia membranacea) on the west coast. This latter record may be based on Friele (1874) who reports it as exceedingly abundant on fucoids in the Bergen area. Norman (1879) also found it in a single locality in Raunefjorden $\left(60^{\circ} 14^{\prime} \mathrm{N}\right)$. Friele $\&$ Grieg (1901), based on a single shell from a deep water station $\left(550 \mathrm{~m}\right.$, outside Andøya, c. $\left.69^{\circ} \mathrm{N}\right)$, extended the distribution from the west coast to Vesterålen. According to Warén (1996b) found north to Lofoten, and Brattegard (in Høisæter et al. 1997a) reports it in 12 of his sectors from eastern Skagerrak to western Finnmark (c. $70^{\circ}$ N). Wikander (1989, 1990) reports eight samples with a total of more than 250 specimens from between seven and $19 \mathrm{~m}$ on the Skagerrak coast. In my material the northernmost records are from Bindalsfjorden, with two specimens from the mouth of the fjord, near Røytvoll $\left(65^{\circ} 12^{\prime}\right.$ $\mathrm{N}, 3-5 \mathrm{~m}$, sand partly covered with algae), and two specimens from Vikestadvågen well inside the fjord $\left(65^{\circ} 07^{\prime} \mathrm{N}, 1.5\right.$ to $1 \mathrm{~m}$, fine sand). Further south, in Flatanger, Nord-Trøndelag, in a very shallow Zostera field, three specimens $\left(64^{\circ} 30^{\prime} \mathrm{N}, 2-0.5 \mathrm{~m}\right)$, and in Sør-Trøndelag, Valsfjorden, Gjelsvik (63 $49^{\prime}$ N, 2 m, Zostera 'meadow' on fine sand) around 360 newly settled juveniles (clearly of the planktotrophic form) and 16 adults. Not a single record from the series from Møre og Romsdal, not even shells. One sample with three specimens from outer Sogn (coll. and leg. Wim Vader), and a very few samples from the Espegrend area.

Rissoa parva (da Costa, 1778) [= Rissoa parva (da Costa, 1779)] - One of the commonest gastropods living on algae anywhere along the coast (e.g. G.O. Sars 1878). Wikander $(1989,1990)$ reports 22 samples with a total of more than 2200 specimens from between 1 and $85 \mathrm{~m}$ on the Skagerrak coast. In my material more than 8000 specimens, 5800 of them from 32 shallow water stations in the Espegrend area, but also shells from four stations in the series from East Finnmark, the northernmost from Nesseby, at the bottom of Varangerfjorden ( $70^{\circ} 09^{\prime} \mathrm{N}, 9-3 \mathrm{~m}$, sand mixed with mud with Laminaria saccharina and other brown algae). Juveniles may be confused with Pusillina inconspicua, but can always be distinguished by their protoconchs, which are much larger, and the more rapid increase of the first few whorls. In most localities in fairly shallow water this species 
is one of the commonest, if not the commonest component of shell grit.

Pusillina inconspicua (Alder, 1844) - Another common species found all around the coast at least from western Finnmark and southwards (G.O. Sars 1878), often together with Rissoa parva, although it has a wider choice of habitats than this species, being found at least down to $100 \mathrm{~m}$ (Warén 1996b). Wikander (1989, 1990) reports 20 samples with a total of more than 270 specimens from the Skagerrak coast. In my material two stations in the series from East Finnmark, both places together with $R$. parva. Found with increasing frequency southwards, until, for some reason its abundance seems to decrease in the series from Møre og Romsdal. Three sizeable samples are 300 specimens from Silavågen in outer Sjona ( $\left.66^{\circ} 19^{\prime} \mathrm{N}\right)$, 22 from Trondheimsleia, the mouth of Dromnessund $\left(63^{\circ} 24^{\prime} \mathrm{N}\right)$, and finally 37 from Raunefjorden, Liholmane $\left(60^{\circ} 18^{\prime} \mathrm{N}, 1 \mathrm{~m}\right.$, on and among Codium). The samples document a high degree of local and geographical variability. The species is characterised by a violet apical tip and very fine axial ribbings. The sample from Liholmane had a maximum size of slightly more than $2 \mathrm{~mm}$, while the general size of the two more northerly samples were around $3 \mathrm{~mm}$, with maximum at least $3.2 \mathrm{~mm}$. There appear to be a gradual decrease of soft part pigments northwards, the Liholmane sample with a conspicuous dark pattern on the head-foot complex, a pattern which is gradually fading away in the two other samples. Also the colour pattern on the shell is much more pronounced on the southernmost specimens. In these samples the large majority of specimens are devoid of axial sculpture except for microscopic growth lines. The axial riblets on the few that do have, seem to differ from one specimen to the next. A single specimen of the 37 from Liholmane had riblets, none with riblets in the two other samples. The riblets in the one specimen were numerous and shallow, starting on whorl no. 3. The colour of the apical tip is not always violet, sometimes it is yellowish (four out of 37 without violet tip). The whorls increase much more slowly than for P. sarsii and Rissoa parva, so that with the same number of whorls $P$. inconspicua specimens are much shorter than any of these (this may not be true of the samples from the Trøndelag and Nordland series). As a whole a confusing 'species' and it is not easy to be convinced that not a species complex is involved here.

Pusillina sarsii (Lovén, 1846) - This species is found associated with algae in shallow water, while the closely related $P$. inconspicua is common on vari- ous substrates in somewhat deeper water. It is reported from western and southern Norway and into Oslofjorden (G.O. Sars 1878). Warén (1996b) gives G.O. Sars (1878) as source for a northern distributional limit in Lofoten, but I have not been able to find this information in G.O. Sars (1878). Wikander $(1989,1990)$ reports 17 samples with a total of more than 260 specimens from the Skagerrak coast. In my material 230 specimens in eight samples from the Espegrend area, of which two reasonably large samples with well preserved specimens. One sample from Liholmane (Codium at $1 \mathrm{~m}$ depth) with 205 specimens, together with 50 Rissoa parva and 37 Pusillina inconspicua. The other sample, from Kviturdsvikpollen (Raunefjorden, muddy bottom with shell-sand and algae at two m depth) contained 11 specimens. The specimens from the latter sample were generally larger (max. c. $4 \mathrm{~mm}$ against max. c. $3 \mathrm{~mm}$ ) although variable, with rounded, shallow axial ribs, while those from the former sample were glossy smooth throughout. The general impression is of a most variable shell for which neither the shape of the shell nor the sculpture have much diagnostic value. This is in accordance with the comments of Warén (1996b) and Graham (1988) of an extremely variable species. Further north only scattered specimens were found, the northernmost a single specimen from 'Pølen' a little enclosed bay just south of Stokksund in Sør-Trøndelag $\left(64^{\circ} \mathrm{N}, 90-50 \mathrm{~m}\right.$, sand mixed with clay, gravel and stones). In addition four empty shells from three stations in Sør-Trøndelag and Møre og Romsdal.

Alvania spp. - The species of this and related groups from northern Europe have been revised fairly recently by Warén (1996a), and I follow his recommendations throughout.

Alvania beani (Hanley in Thorpe, 1844) [= Alvania beanii (Thorpe, 1844 ex Hanley MS] - This is a shallow water (down to ca. $40 \mathrm{~m}$ ), boreal species, in Norway recorded from Oslofjorden (Jeffreys 1870), along the Skagerrak coast (five samples from 14 to $57 \mathrm{~m}$, with altogether 35 specimens, Wikander 1989, 1990), the west coast (G.O. Sars 1878), north to ca. $63^{\circ} 30^{\prime} \mathrm{N}$ (Warén 1996a). I have one fresh looking shell (ca. 3.4 $\mathrm{mm}$ long) from far north of this latitude, i.e. from just NE of Røsøy (SW of Bodø, 67 16’ N, 13 m, coarse shell gravel, shells and Laminaria). In addition a number of specimens are from north of $63^{\circ} 30^{\prime} \mathrm{N}$. The northernmost sample, with eight specimens is Risvær-fjorden, SE of Steinsøy (64 59' N, 28-24 m, gravel, slag, stones and red algae). Another sample (with five specimens and 12 shells) is from $\mathrm{W}$ of 
Svinøy (64 55' N, 175-20 m, shell sand), and yet another (four specimens and nine shells) from outer Namsenfjorden $\left(64^{\circ} 35^{\prime} \mathrm{N}, 60-11 \mathrm{~m}\right.$, sand mixed with clay, gravel). Apparently the species is fairly common among islets and skerries on the outer coast at $64^{\circ}$. $65^{\circ} \mathrm{N}$. In the material from Møre og Romsdal county only 16 shells (and a single specimen) from three samples. In comparison 68 specimens were found in 12 samples from the Espegrend area.

Alvania cimicoides (Forbes, 1844) - According to Warén (1996a) occurring from Hammerfest (70 40’ N), (apparently based on a single specimen reported by G.O. Sars 1878) and southwards along the coasts of Europe. Wikander $(1989,1990)$ reports four samples with a total of nine specimens from the Skagerrak coast. This species has a more robust shell than $A$. beani, with coarser sculpture and distinctly channeled suture. It appears to replace $A$. beani from $\mathrm{c}$. $40 \mathrm{~m}$ downwards on silt covered and current swept rocky and sandy substrates. In my material around 90 specimens and an additional 890 shells. Forty-one of the specimens were from Møre og Romsdal and 34 from the Espegrend area. It is probably not very common north of Lofoten, and I have only a single specimen in my six samples from the series from Andfjorden (east of Andøya, 69 $17^{\circ} \mathrm{N}, 80-60 \mathrm{~m}$, coarse shell gravel). From Bodø and southwards it seems to be evenly distributed everywhere, found in respectively 17, 17, 13 and 12 samples in the four sectors from north to south.

Alvania incognita Warén, 1996 - A. incognita was described from several specimens found on/in a piece of sunken driftwood at $1270 \mathrm{~m}$ southwest of Iceland $\left(63^{\circ} 21^{\prime} \mathrm{N}\right.$, $27^{\circ} 05^{\prime} \mathrm{W}$ ), but has since been found at two localities northwest of Iceland at $659 \mathrm{~m}\left(66^{\circ} 31^{\prime} \mathrm{N}\right.$, also sunken piece of driftwood) and $894 \mathrm{~m}\left(68^{\circ} 04^{\prime} \mathrm{N}\right)$ respectively. Apparently not reported since it was described. In my material a single specimen, c. 1.5 $\mathrm{mm}$ long from the slope at $870 \mathrm{~m}\left(70^{\circ} \mathrm{N}, 17^{\circ} \mathrm{E}\right.$, same haul as Alvania aff. moerchi) best fit the description of this species.

Alvania jeffreysi (Waller, 1864) - Another species known from the whole coast, including East Finnmark, in fairly high numbers (G.O. Sars 1878). Found on the same types of substrate as A. cimicoides, from $75 \mathrm{~m}$ downwards to at least $300 \mathrm{~m}$ (Warén 1996a). Wikander $(1989,1990)$ reports four samples with a total of six specimens from the Skagerrak coast. In my material 10 specimens from two stations in the Andfjorden area, the northernmost from the coral reef in outer Andfjorden ( $69^{\circ} 14^{\prime} \mathrm{N}, 370 \mathrm{~m}$ ), six from three stations in Nordland south of Bodø, three in three samples from Nord-Trøndelag, and 17 from four Møre og Romsdal stations. The richest sample was from the open coast outside Kristiansund $\left(63^{\circ}\right.$ $10^{\prime} \mathrm{N}, 145-80 \mathrm{~m}$, stones and gravel) from which 14 specimens were picked out. In many of the samples it was found together with A. cimicoides. Available information on substrate and depth indicate that both species were most abundant in depths between 100 and $150 \mathrm{~m}$, and sandy or mixed substrates (stones, shells, especially Modiolula phaseolina shells, and sand).

Alvania moerchi (Collin, 1886) - This species, described from $90 \mathrm{~m}$ in the Kara Sea, was classified by Bouchet \& Warén (1993) as an Arctic shallow water species, but was recorded by Warén (1996) from 16 stations northeast and east of Iceland between 250 and 678 $\mathrm{m}$, and by Warén (in Sneli et al. 2005) from $650 \mathrm{~m}$ just north of the Faroes. In my material 12 specimens from two stations just north of the Norwegian Trench $\left(62^{\circ} 30^{\prime} \mathrm{N}, 602-604 \mathrm{~m}\right)$. New to the Norwegian fauna.

Alvania aff. moerchi - Two specimens, 3.2 and $3.0 \mathrm{~mm}$, from the slope $\mathrm{NW}$ of Malangsgrunnen $\left(70^{\circ} 12^{\prime} \mathrm{N}\right.$, $17^{\circ} 01^{\prime}$ E, $870 \mathrm{~m}$, coll. and leg. J.-A. Sneli) show some similarities to A. moerchi, but an orange-red colouration of the lower half of the shell has never been observed on that species. Warén (in litt.) has indicated that he has some material of the species from methane seeps on the slope at Storegga, and is of the opinion that this is an undescribed species.

Alvania pseudosyngenes (Warén, 1973) - Illustrated and briefly discussed in Bouchet \& Warén (1993) and Warén (1996a). Apparently not encountered in Norwegian waters since the type material was taken from the slope outside Senja $\left(69^{\circ} 46^{\prime}\right.$ N, c. $\left.1200 \mathrm{~m}\right)$. Not in my material.

Alvania punctura (Montagu, 1803) - An abundant shallow water species recorded from the whole coast with the exception of East Finnmark (G.O. Sars 1878, Warén 1996a). Found down to ca. $40 \mathrm{~m}$, on “.... undisturbed bottoms with fine sand or silt, also on algae and under low intertidal rocks with good water circulation." (Warén 1996a). Wikander $(1989,1990)$ reports 12 samples with a total of 34 specimens from the Skagerrak coast. Probably uncommon north of Lofoten. In my material only a single shell in the the series from Andfjorden (East of Andøya, 69 $17^{\circ} \mathrm{N}$, 80-60 m, coarse shell gravel). Further south generally the most, or close to the most, abundant Alvania 
species. The exception is the series from Møre og Romsdal where $A$. cimicoides, $A$. jeffreysi and $A$. subsoluta were far more abundant, both alive and as empty shells. In the Espegrend area A. punctura outnumbered the other species, with more than 200 specimens sorted out of 35 samples.

Alvania subsoluta (Aradas, 1847) - A soft bottom, deep water species that often occur in high densities on suitable bottoms in the fjords and along most of the coast. According to Warén (1996a): "Muddy or slightly silty bottoms from about $150 \mathrm{~m}$ and deeper". Like the last species probably uncommon north of Lofoten, although one shell was found at station 195 of the Norwegian North Atlantic Expedition 1876-78 (Warén 1973). This station, on Tromsøflaket $\left(70^{\circ}\right.$ $55^{\prime} \mathrm{N}, 18^{\circ} 38^{\prime} \mathrm{E}, 196 \mathrm{~m}$ ) may be the only one north of Lofoten. Warén (1996a) reports two specimens from outer Vestfjorden $\left(67^{\circ} 43^{\prime} \mathrm{N}, 13^{\circ} 35^{\prime} \mathrm{E}, 250\right.$ M). Wikander $(1989$, 1990) reports four samples with a total of 11 specimens from the Skagerrak coast. In my material numerous specimens from five stations in the Nordland south of Bodø series, the northernmost at $67^{\circ} \mathrm{N}$, but an especially rich one was from Oterværfjorden ( $66^{\circ} 43^{\prime} \mathrm{N}, 340-300 \mathrm{~m}$, silt), somewhat fewer records from the Nord-Trøndelag and Møre og Romsdal series. Finally more than 1400 specimens from nine stations in the Espegrend area. The distribution usually confined to the outermost fjord basins, like Sognesjøen and Oterværfjorden.

Alvania cf. scrobiculata (Møller, 1842) - A. scrobiculata has been reported from Varangerfjorden and its tributary Bugøyfjorden in East Finnmark, but not further west or south on the Norwegian coast (Warén 1974, 1996a). In my material a single shell from the shelf outside Korsfjorden ( $60^{\circ} 07^{\prime}$ N, 290$285 \mathrm{~m}$, ooze with sponges), and one from outside Rongøy in Øygarden ( $60^{\circ} 29^{\prime} \mathrm{N}, 80-75 \mathrm{~m}$, fine shell sand and clay) may belong to this species. The shell from outside Korsfjorden and a subfossil one from Bohuslän were both identified by Warén. They have all the typical diagnostic features of the species. The shell from outside Rongøy is rather atypical though. It is longer, having one more whorl, and more slender (increasing less rapidly in diameter). The protoconch is (apparently) more knoblike and dominating. These shells are most likely glacial fossils.

Alvania testae (Aradas \& Maggiore, 1844) [= Alvania abyssicola (Forbes, 1850)] - According to Warén (1996a) this species should be fairly common in 50-300 m depths on silty to slightly muddy bottoms along the coast from Trondheimsfjorden, $63^{\circ} 30^{\prime} \mathrm{N}$ and southwards. Sometimes found together with $A$. subsoluta, but never found in high numbers (Warén 1996a). Wikander (1990) reports a single specimen (as A. abyssicola (Forbes, 1850)) from $160 \mathrm{~m}$ silty bottom due east of Kristiansand ( $\left.8^{\circ} 23^{\prime} \mathrm{E}\right)$. In my material a single, not quite fresh shell from Rovdefjorden, NE av Kropperevet $\left(62^{\circ} 11^{\prime}\right.$ N, 200 - 150 m, sand).

Alvania verrilli (Friele, 1886) - Illustrated and briefly discussed in Bouchet \& Warén (1993) and Warén (1996a). Apparently not encountered in Norwegian waters since the type material was taken from the slope outside Senja $\left(69^{\circ} 46^{\prime}\right.$ N, c. 1200 m). Not in my material.

Alvania wyvillethomsoni (Friele, 1877) - This typical slope species is illustrated and discussed in Warén (1973, 1996) and Bouchet \& Warén (1993). The two photos, Figs 1480 and 1481 in Bouchet \& Warén (1993), indicate a high degree of variability in shape and sculpture. Shells completely without axial folds are typical of some local populations from deep water (e.g. c. $1600 \mathrm{~m}$ north of Iceland, see below). It is known mainly from depths below $600 \mathrm{~m}$ with negative temperatures on the slope outside the Norwegian coast from $62^{\circ} 15^{\prime} \mathrm{N}$ (Grieg 1915) and northwards, and in negative temperatures north and east of Iceland and the Faroes. Also found from $235 \mathrm{~m}$ and downwards in far northern waters (north of $71^{\circ} \mathrm{N}$ ) (Warén 1973). Not mentioned in Bouchet \& Warén (1979), and thus probably not present below c. $2500 \mathrm{~m}$. In my material 338 specimens of several sizes (up to c. $4.5 \mathrm{~mm}$ ) in 17 slope samples from 543 to $1700 \mathrm{~m}$. Six specimens from three stations at 2019 to $2104 \mathrm{~m}$, are my only finds from deeper than $2000 \mathrm{~m}$. Apparently fairly common around the whole Norwegian Sea basin.

Alvania zetlandica (Montagu, 1815) [= Manzonia zetlandi$\mathrm{ca}$ - Known from the upper slope outside Andøya (c. $69^{\circ} \mathrm{N}, 550 \mathrm{~m}$, Friele \& Grieg 1901) and southwards along the coast, $30-300 \mathrm{~m}$, on sandy, gravelly and silty bottoms, swept by currents. Never in great numbers (Warén 1996a). In my material shells from two coral reef stations in outer Andfjorden (Steinavær, 69 $14^{\prime}$ $\mathrm{N}, 370 \mathrm{~m}$ ). Further south it is found sparingly, for the most part as shells only, at five of the stations from Nordland south of Bodø, 11 of the Nord-Trøndelag stations and seven of the Møre og Romsdal stations. In my material from the Espegrend area there are 16 specimens, 12 of which are from three samples from the same locality in Liholmsrennen $\left(60^{\circ} 18^{\prime} \mathrm{N}\right.$, 60-100 m, slag and stones and Modiolula phaseolina shells). In the same three samples were also several specimens of $A$. cimicoides and A. jeffreysi, and in 
the two shallowest (60-80 m) of A. punctura as well.

Alvania n. sp. - Based on a single worn shell from the shelf outside the island One in Øygarden (60³ $30^{\prime} \mathrm{N}, 75-80$ $\mathrm{m}$, fine shell sand and clay). This shell is similar to $A$. jeffreysi, and might be a somewhat atypical member of that species. The main difference is a distinct keel on the body whorl produced by spiral ridge no. three from top, and very indistinct axial ribs. The latter may be a result of partial erosion. It also has a wider apical angle, thus being wider than shells of $A$. jeffreysi of the same length. The sutures are deep, thus giving the shell a cork screw appearance when looked at from the top. The protoconch is narrower but somewhat higher than, and the protoconch sculpture is similar (but not identical) to the one in A. jeffreysi.

Boreocingula castanea (Møller, 1842) - Confirmed as occurring in Norwegian waters in Warén (1996a) (earlier records based on misidentified material). Based on a single shell recorded from Byluft, Varangerfjord $\left(70^{\circ} 04^{\prime} \mathrm{N}, 25 \mathrm{~m}\right)$. Not in my material.

Cingula trifasciata (J. Adams, 1800) - A southern, littoral species that occurs sparingly but locally common on the west coast, from $58^{\circ} 30^{\prime} \mathrm{N}$ and north to Trondheims-fjorden (63 30' N) (Warén 1996a). In my material three lots, two from Eggholmen, Raunefjorden $\left(60^{\circ} 15^{\prime}\right.$ N, 20 and 50 specimens respectively) and one from Steinskjær in Raunefjorden (two specimens). In addition one shell marked 'Storholmen, Hustad, mai 1965', (62 $\left.58^{\prime} \mathrm{N}\right)$ and one shell marked 'The littoral on SW Kalsøy, 16/9 1958' (6007' N). All samples from underneath stones in the littoral zone, and with one exception in the immediate vicinity of Espegrend.

Crisilla semistriata (Montagu, 1808) [= Alvania (Crisilla) semistriata] - According to Warén (1996a) a fairly common littoral to upper sublittoral species in western Norway, north to Trondheimsfjorden, 63 $30^{\prime} \mathrm{N}$. By G.O. Sars (1878) recorded from Oslofjorden and western Norway. In my material a single specimen from Knappensundet, Straume bridge (60 $19^{\prime}$ N, 6.5 $\mathrm{m}$, blackish silt between stones and shells).

Frigidoalvania janmayeni (Friele, 1878) - Except for a few subfossil shells from outside Korsfjorden (c. $60^{\circ} 08^{\prime} \mathrm{N}$ ), this species has apparently been found in Norwegian waters only twice before, in Varangerfjorden and its tributary Bugøyfjorden (Norman 1902, Warén 1973). In my material two specimens from Varangerfjorden (70 04' N, 29 $12^{\circ}$
E, $174 \mathrm{~m}$, fine sand).

*Manzonia crassa (Kanmacher, 1798) - Warén (1996a) has found a number of fresh-looking shells of this southern, shallow water species in the Raunefjorden area (around $60^{\circ} 15^{\prime} \mathrm{N}$ ). Also a number of fresh looking shells from Oslofjorden and the Swedish west coast in museum collections. Although not yet found alive in Scandinavia, the likelihood is high that the species still live here. In my material, three worn shells, probably subfossil from Korsfjorden, NW of Skorholmen (60 $09^{\prime} \mathrm{N}$, coll. \& leg. A. Warén).

Obtusella intersecta (S.V. Wood, 1841) [= Obtusella alderi Jeffreys, 1858] - This is a shallow water (down to c. $40 \mathrm{~m}$ ) species, in Norway so far recorded from Oslofjorden (reported by Brøgger 1872 but not repeated in G.O. Sars 1878) north to c. $69^{\circ} 42^{\prime}$ N, and often found in large quantities on sandy and silty bottoms with scattered algae (Warén 1996a). Wikander $(1989,1990)$ reports five samples with a total of more than 500 specimens from the Skagerrak coast. In my material high numbers of specimens from suitable habitats all around the coast from the Espegrend area at least north to Silavågen in outer Sjona ( $66^{\circ} 19^{\prime} \mathrm{N}$, 20-18 m, very soft substrate at least 150 specimens). Further north shells only from three samples in Nordland south of Bodø, and four samples in the series from Andfjorden of which only some shells from Kvæfjorden ( $68^{\circ} 41^{\prime}$ N, 30-8 m, shell sand to a large degree covered with algae) are indisputable.

Obtusella tumidula (G.O. Sars, 1878) - This species was described by G.O. Sars from a single specimen found in the intertidal near Vardø $\left(70^{\circ} 20^{\prime} \mathrm{N}, 31^{\circ} \mathrm{E}\right)$. This was the only known specimen for more than a century, until Warén (1989) determined one specimen and a number of shells from northern Iceland (from the littoral down to ca. $30 \mathrm{~m}$ ). He also included a single shell from the shelf-slope break (407 m) north of Iceland. Unfortunately in the same article he claimed that the rather different deep water species Rissoa griegi (Friele, 1879) was a synonym. This latter was described from specimens taken from a piece of sunken drift wood with Teredo boreholes, taken from c. $2400 \mathrm{~m}$ just west of Spitsbergen. This synonymisation has since been retracted (Warén in litt, 2008). Later Warén (1996) included 18 specimens from three BIOICE stations on the Iceland-Faroe Ridge just east of Iceland, at respectively c. 400, 407 and 563 $\mathrm{m}$. He also included three specimens from a station on the upper slope (542 m) south of the Faroes. Nine specimens from a station on the upper slope (497 m) just north of the Norwegian Trench (at $62^{\circ} 30^{\prime} \mathrm{N}, 2^{\circ}$ 
08’ E) are exactly like the SEM photos of a specimen from Skjalfandi, northern Iceland, in Warén (1989). Especially the large, dome shaped protoconch with a regular pattern of more than 25 fine spiral ridges is distinctive. This species thus seems to have invaded the shelf/slope-break region in Norwegian waters from the shelf on the Iceland-Faroe Ridge. The temperatures appear to be positive in the recorded localities.

Onoba aculeus (Gould, 1841) - This is a littoral species occurring all along the Norwegian coast (G.O. Sars 1878). Wikander $(1989,1990)$ reports five samples with a total of 35 specimens from the Skagerrak coast. In my material a sample of 20 specimens from the stony littoral in Kjøfjorden, Sør-Varanger $\left(69^{\circ}\right.$ $\left.48^{\prime} \mathrm{N}\right)$. At the other extreme a sample containing 37 specimens from Raunefjorden (littoral, stone and gravel, S. Eggholmen, $60^{\circ} 15^{\prime} \mathrm{N}, 14 / 6-66$, together with 20 specimens of Cingula trifasciata). In addition three other samples from the Espegrend area. The specimens from Sør-Varanger appear to be 'fatter', with a thicker, more distinct periostracum (yellow to brownish), and often with clear erosion marks on the top part of the shell. While this species occurs regularly in shell grit below the littoral zone, it is rarely found in such large quantities as $O$. semicostata.

Onoba islandica (Friele, 1886) - The author erroneously listed in CLEMAM as (Friele, 1876). This species was described from $547 \mathrm{~m}$ on the Iceland-Faroe Ridge, off eastern Iceland, and has since been recorded from around Iceland from 212 to $640 \mathrm{~m}$, and with two specimens from 683 m northeast of the Faroes (Bouchet \& Warén 1993, Warén 1996a). In my material 33 specimens from seven stations on the upper slope, from 543 to $830 \mathrm{~m}$, most of them from the same transect at $62^{\circ} 12^{\prime}$ to $62^{\circ} 35^{\prime} \mathrm{N}$, but the deepest record was a single specimen from c. $63^{\circ} 10^{\prime} \mathrm{N}$. New to the Norwegian fauna.

Onoba semicostata (Montagu, 1803) - A common species from the upper sublittoral all along the coast north to $69^{\circ} 24^{\prime} \mathrm{N}$ (Warén 1996a). Wikander $(1989,1990)$ reports 10 samples with a total of 38 specimens from the Skagerrak coast. In my material specimens in moderate quantities in a few samples from each of the cruises, the northernmost a single specimen from Grovfjorden ( $68^{\circ} 41^{\prime} \mathrm{N}, 40-20 \mathrm{~m}$, stones and coarse gravel). Further south, 19 from Silavågen in outer Sjona $\left(66^{\circ} 19^{\prime} \mathrm{N}, 20-18 \mathrm{~m}\right.$, very soft substrate), seven from Vefsnfjorden ( $65^{\circ} 53^{\prime} \mathrm{N}, 15-12 \mathrm{~m}$, Lithothamnion and Desmarestia), one to three from each of 10 stations in the Nord-Trøndelag series, three from two samples from Møre og Romsdal, but more than 450 from 26 stations in the Espegrend area. Shells often found in enormous quantities in shell grit in samples from Nordland. Together with Rissoa parva the dominating gastropod species in this substrate. Not dominating to the same extent in samples from the other four cruises.

Onoba cf. improcera Warén 1996 - Based on two specimens and several shells from outer Gratangen $\left(68^{\circ}\right.$ $44^{\prime} \mathrm{N}, 80-90 \mathrm{~m}$, mixed substrate with much fine sediment, two specimens and nine shells) and from the upper slope northwest of Andøya (69 $17^{\circ} \mathrm{N}, 15$ empty shells). Several of the shells from Gratangen with golden-brown periostracum. They look somewhat like Onoba improcera as illustrated in Warén (1996a), but also have certain similarities to Onoba mighelsi. Warén described O. improcera in 1996 based on material from northern Iceland, and included several specimens from northern Norway (the southernmost from Tromsøysundet, $69^{\circ} 40^{\prime} \mathrm{N}$ ), previously (Warén 1974) identified as Alvania mighelsi. A fragmentary shell (subfossil?) from the shelf outside Korsfjorden $\left(60^{\circ} 08^{\prime} \mathrm{N}, 300-400 \mathrm{~m}\right)$ was identified as Alvania mighelsi by Warén, probably in 1973. O. mighelsi is stated (by Warén 1996a) to be a purely Arctic species, not present in Norwegian waters: 'Distribution. Here confirmed from $55^{\circ} \mathrm{N}$ and northward in Alaska; Maine to Newfoundland and western Greenland; northeastern Iceland and Svalbard, in 0-150 m depth'. If my material indeed belong to a described species, I regard $O$. improcera as the most likely candidate. The locality mentioned above from outer Gratangen would thus represent a new southern distributional limit.

*Pseudosetia semipellucida (Friele, 1879) [= Setia semipellucida] - Illustrated and briefly discussed in Bouchet \& Warén (1979, 1993) and Warén (1996a). Recorded from the abyssal parts of the Norwegian Sea, and recently also from the slope north of the Faroes $\left(63^{\circ}\right.$ $01^{\prime}$ N, $698 \mathrm{~m},-0.6^{\circ} \mathrm{C}$ ) (Bouchet \& Warén 1993 and Warén in Sneli et al. 2005). In my material several specimens from ROV Dive 3 of Biodeep 2007, north of Jan Mayen, around 2400 m. Friele \& Grieg (1901) mention several 'completely smooth' specimens of Rissoa turgida from the slope outside Senja $\left(69^{\circ} 46^{\prime}\right.$ $\mathrm{N})$, at $1187 \mathrm{~m}$, that most probably are specimens of $P$. semipellucida. In view of the presence of this species on the slope north of the Faroes, it is likely that the species is living in negative temperatures on the slope outside Norway. Not in my material from the slope of the Norwegian Sea. 
Pseudosetia turgida (Jeffreys, 1870) [= Setia turgida - A fairly common species on deep (100-600 m) slightly current swept, muddy to silty bottoms, along the whole coast, (Warén 1996a). However not reported from East Finnmark (G.O. Sars 1878, Norman 1902). In my material the northernmost record from outer Gratangen (68 44' N, 90-80 m, fine shell sand with much Modiolula phaseolina), and the southernmost from Fanafjorden $\left(60^{\circ} 14^{\prime} \mathrm{N}\right)$, fairly common, most abundant in the southern part (41 specimens from the Espegrend area and a total of 28 specimens from Møre og Romsdal).

Caecum glabrum (Montagu, 1803) - This southern, shallow water, interstitial species has apparently only been recorded once from Norwegian waters since it was listed in G.O. Sars (1878) as present in Oslofjorden and on the west coast. Thus it was recorded by Norman (1879) from three localities in the Raunefjord-Korsfjord area. Earlier found by Friele (1874) as rare around Kvarven (in Bergen) and by M. Sars at Manger (north of Bergen). In my material a sample from Sandfjorden $\left(62^{\circ} 16^{\prime} \mathrm{N}, 50-25 \mathrm{~m}\right.$, shell sand and gravel) contained a single specimen and nine shells. A single shell from Stokksundet $\left(64^{\circ}\right.$ $\left.03^{\prime} \mathrm{N}\right)$, eight shells from Outer Namsenfjorden ( $64^{\circ}$ $36^{\prime} \mathrm{N}, 420 \mathrm{~m}$, clay), and finally a single shell from Lamholmen, north of Gjerdingen (64 $57^{\prime} \mathrm{N}, 80-30$ $\mathrm{m}$, gravel and shells), so far the northernmost record. Otherwise 48 specimens taken throughout a year (9 occasions) from a single locality in Raunefjorden (Hillersholmen, $60^{\circ} 18^{\prime} \mathrm{N}, 6$ to $8 \mathrm{~m}$, shell sand and shells with lots of Pomatoceros). In a recent, species rich sample from Bukkasundet, Raunefjorden $\left(60^{\circ} 14^{\prime} \mathrm{N}, 19-8 \mathrm{~m}\right.$, shell sand and Laminaria) 22 specimens were found. Most of the specimens from Hillersholmen were found in the sand fraction whenever the sand fraction and Pomatoceros fraction were sorted separately.

Specimens from Hillersholmen vary a lot conchologically, and often specimens from the same sample have rather different aspects. Especially the colour of the periostracum vary, mainly because of different degrees of incrustation. The colour varies from light yellowish, clear and translucent to opaque yellowish brown sometimes with black blotches. The shell has a fur-like densely haired periostracum, obscuring any fine sculpture the shell might have. I am not certain that my material really belong to Caecum glabrum. Available illustrations (e.g. Graham 1988) show a much smaller shell, and I have found no reference anywhere to the very distinct hairy periostracum.
* Elachisina globuloides (Warén, 1972) [= Boreocingula globuloides] - A single, possibly subfossil, shell from the shelf outside Korsfjorden $\left(60^{\circ} 07.5^{\prime}\right.$ N, 315 $317 \mathrm{~m}$, sand and ooze) was included as a paratype in the description of Cingula globuloides (Warén, 1972b). The type locality was given as: 'E. of New Foundland, $49^{\circ} 41^{\prime} \mathrm{N}, 52^{\circ} 09^{\prime} \mathrm{W}, 340 \mathrm{~m}$, fine clay'. This species was later transferred to Boreocingula (e.g. in Hansson 1998) and more recently (Warén 1996a) transferred to Elachisina. By mistake the shell from western Norway was not included in the 'Distribution' part for the latter, but Warén (in litt 2008) confirms that he still regards this shell as conspecific with the western Atlantic E. globuloides, recently also found in Greenland. In any case not in my material, and not yet confirmed to be part of the recent Norwegian fauna.

Hydrobia neglecta Muus, 1963 - Taxonomy discussed in Wilke et. (2000) who, based on molecular genetic evidence, conclude that $H$. neglecta is a subspecies of H. acuta (Draparnaud, 1805). H. neglecta is still accepted as a valid species in Clemam. Apparently distributed all along the coast (but this is based on the premise that $H$. neglecta is a synonym of $H$. minuta sensu G.O. Sars. According to G.O. Sars, H. minuta is by far the commonest species of the genus in Norway, H. ulvae being far less common, and not found north of Lofoten). If my identifications are correct, not in my material.

Hydrobia ulvae (Pennant, 1777) - According to Friele \& Grieg (1901) the northern limit of H. ulvae in Norway is Kjosen (an arm of Ullsfjorden, 69 $35^{\circ} \mathrm{N}$ ). Wikander (1990) reports 14 samples with a total of more than 1300 specimens from the Skagerrak coast. Many of these were marked as uncertain though. In my material (provided correct identification, see $H$. neglecta above) a common species in the muddy littoral zone all along the coast. I have material from the bottom of Bugøyfjorden ( $69^{\circ} 52^{\prime} \mathrm{N}$ ), several sizeable lots from Bindalsfjorden ( $\left.65^{\circ} 07^{\prime} \mathrm{N}\right)$, Jøssundfjorden $\left(64^{\circ} 30^{\prime} \mathrm{N}\right)$, and Valsfjorden $\left(63^{\circ} 49^{\prime} \mathrm{N}\right)$ wherever the algae- or Zostera-covered fine sediment in the littoral or upper sub-littoral were sampled. This habitat only sampled occasionally during the other cruises, so only scattered specimens were found.

Potamopyrgus antipodarum (Gray, 1843) [= Potamopyrgus jenkinsi (E.A. Smith, 1889)] - This introduced freshwater snail sometimes extends marginally into brackish water. Reported from Iddefjorden (Hansson 1998). Found by Wikander (1990) at three stations in Grimstad municipality on the Skagerrak coast, $1 \mathrm{~m}$, 
muddy/sandy bottom. Not in my material.

Ventrosia ventrosa (Montagu, 1803) [= Hydrobia ventrosa] - A brackish water species. Found by Jeffreys (1870) in Oslofjorden, and Wikander (1990) in two stations in Lillesand and three in Grimstad municipalities on the Skagerrak coast, between 2 and $9 \mathrm{~m}$. Four of these records are marked as uncertain though. Not in my material.

*Ceratia proxima (Forbes \& Hanley, 1850) - Reported by G.O. Sars (1878) from both southwestern and southeastern Norway. This species has been discussed by Bouchet \& Warén (1993) and Warén (1996a), who claim that it is not part of the Scandinavian fauna. According to Warén all shells reported from Norwegian waters are weakly sculptured specimens of Onoba aculeus. The northern distributional limit is supposed to be on the southwestern coast of Ireland. So far unpublished records from several oil fields in the North Sea (Warén in litt. 2008) indicate that it may be expanding its distribution northwards. In my material two shells with protoconchs rather different from a typical $O$. aculeus, both from the outer coast near Espegrend. One of the two had remnants of a yellow periostracum with no visible striation. The striation is also very weak in the other one, which is whitish and lack periostracum. However, not yet confirmed to be part of the Norwegian fauna.

Hyala vitrea (Montagu, 1803) - According to G.O. Sars (1878) found in several localities at the southern coast of Norway. Mentioned by Nordgaard (1915) as one of two species only known as fossils from Oslofjorden, but still living at the south coast. Warén (1996a) reported it as extant from Oslofjorden at c. 59 $39^{\circ}$ N. Wikander $(1989,1990)$ reports 30 samples with a total of more than 100 specimens from the Skagerrak coast. In my material, altogether 66 specimens from Ølsfjorden in Sunnhordland (c. 59 $36^{\circ} \mathrm{N}, 43 \mathrm{~m}$ and 23, soft bottom, collected in October 2006, donated by Per J. Johannessen). This is a new northern distributional limit along the west coast. Claimed to inhabit the burrows of Nephrops and related species (Warén 1996a). In the investigation in Ølsfjorden, no individuals of Nephrops were caught, but the thalassinidean shrimp, Upogebia deltaura was co-occurring with $H$. vitrea in three out of four grab samples.

*Circulus sarsi (Bush, 1898) [= Omalaxis supranitida (S. Wood, 1848)] - This species has been found only once before, by G.O. Sars (1878) who reported a single shell from $370 \mathrm{~m}$ in Lofoten. Bush (1898) found it to be different from the fossil Adeorbis supranitidus
Wood, and renamed it Omalaxis sarsi ("For this very distinct species, which does not seem to be very closely related generically to Circulus, I propose the name Sarsi, but very much doubt its near relation even to Omalaxis"). In Ponder (1990) the species is preliminarily named Orbitestella sarsi (Bush, 1898), based on the advice of Warén. This name is also used by Hansson (1998). Orbitestella sarsi is not mentioned in CLEMAM however. As I cannot find any obvious conchological similarities between available illustrations of Orbitestella spp. and the illustration of G.O. Sars, I have in lack of a better alternative chosen to accept Adam \& Knudsen's (1969) concept of the genus Circulus. Adam \& Knudsen present good drawings of four species from West Africa, of which one, C. pseudopraecedens Adam \& Knudsen, 1969, has much the same spiral sculpture as is seen in the drawing of G.O. Sars. I agree with Bush that Sars' species is specifically distinct from Adeorbis supranitidus, and conclude that $C$. sarsi is as good a name as any. In my material a single, old, very fragile shell from the outer part of Folda-fjorden $\left(64^{\circ} 41^{\prime}\right.$ N, 200-120 m, coral gravel). Unfortunately severely broken during examination!

Aporrhais pespelecani (Linné, 1758) - A common sand living species along most of the Norwegian coast. Recorded north to $70^{\circ} \mathrm{N}$ (G.O. Sars 1878) who claimed it to be very rare north of $68^{\circ} \mathrm{N}$. Wikander $(1989,1990)$ reports 47 samples with a total of more than 250 specimens from the Skagerrak coast. In my material 11 specimens from outer Austerfjorden (Gullesfjorden $68^{\circ} 40^{\prime} \mathrm{N}, 60-25 \mathrm{~m}$, mud and sand, some red algae), three specimens from two stations in the series from Nordland south of Bodø, 23 specimens from six stations in the Nord-Trøndelag series, and 15 specimens from four stations in the Møre og Romsdal series. The species is common in the Espegrend area, but it is not represented by more than 11 specimens in my material.

Aporrhais serresianus (Michaud, 1828) - The main difference between the two species of Aporrhais is the form and size of the extended outer lip. However, when some of the processes of $A$. serresianus are broken, and for young individuals before the outer lip is fully developed, other characters are needed. The spire is narrower with much finer sculpture in A. serresianus, most easily seen in the number of 'knobs' on the peripheral keel (and the one below) on the body whorl. The distinction is not always very clear-cut, and some of the identifications are doubtful, not least because of frequent erosion of the upper part of the spire. For description of the larval 
shell, see Bouchet \& Warén (1993). This soft bottom species is known from Lofoten $\left(68^{\circ} \mathrm{N}\right)$ southwards, but not from the southern coast (G.O. Sars 1878, Nordgaard 1915). Sneli (1968) reports it from the area of Drøbak and further south in Oslofjorden, based on material kept in the Zoological Museum, Oslo. Not mentioned in Wikander $(1989,1990)$. In my material no specimens north of Voldafjorden $\left(62^{\circ} 09^{\prime}\right.$ $\mathrm{N})$, or shells north of Frenefjorden $\left(62^{\circ} 50^{\prime} \mathrm{N}\right)$. In the Espegrend area most specimens from Fanafjorden, $\left(60^{\circ} 14^{\prime} \mathrm{N}, 140-170 \mathrm{~m}\right.$, silt and clay).

*Haloceras aff. laxa (Jeffreys, 1885) - This name was introduced in Bouchet \& Warén (1993) for two shells from the northern part of the Bay of Biscay. It was further described and illustrated in Warén (1993), based on one specimen from $900 \mathrm{~m}$ in the FaroeShetland Channel and one from $700 \mathrm{~m}$ northwest of the Faroes. Later, specimens from two more stations around the Faroes has been recorded (Warén in Sneli et al. 2005), the shallowest from $260 \mathrm{~m}$ on the shelf east of the Faroes. Recently a postlarva was found in a sample from Visund oil field, on the western 'slope' of the Norwegian Trench $\left(61^{\circ} 20^{\prime} \mathrm{N}, 339 \mathrm{~m}\right.$, Per Johannessen leg.) and another juvenile from Snorre oil field at the same latitude, somewhat further up the slope (305-308 m, Anders Warén leg.). These two records are both from 2008, and might be examples of a recent invasion. Still not a verified member of the Norwegian fauna as identified here, but it is getting close.

Crepidula fornicata (Linné, 1758) - This introduced species has not yet been recorded from the coast north of Rogaland. The presently known northern limit is Kvitsøy, Rogaland (59 04' N, see Sjøtun 1997). Apparently not uncommon on the Norwegian Skagerrak coast, as Wikander $(1989,1990)$ reports four samples with a total of 11 specimens. In my material a specimen from Nevlunghavn $\left(9^{\circ} 52^{\prime} \mathrm{E}\right)$ collected in 1968.

Capulus ungaricus (Linné, 1758) - A species found frequently, if usually only one or a few specimens at a time, along the whole coast from Hammerfest $\left(70^{\circ} 30^{\prime} \mathrm{N}\right)$ southwards (G.O. Sars 1878). So far not reported from East Finnmark. The species is known to be a 'semi-parasite' of several bivalves and stationary gastropods, and also some brachipods, and lives sublitorally in moderate depths, down to at least 500 m. Wikander $(1989,1990)$ reports seven samples with a total of nine specimens from the Skagerrak coast. In my material one specimen from each of two stations in outer Andfjorden, one east of Breivikøyra,
Andøya ( $69^{\circ} 12^{\prime} \mathrm{N}, 125 \mathrm{~m}$ ) and one in Sifjord, Senja $\left(69^{\circ} 16^{\prime} \mathrm{N}, 110-90 \mathrm{~m}\right)$. Further south it was found in every sector, but with increasing frequency southwards. Altogether 28 specimens recorded, of which 18 from the Espegrend area.

Torellia delicata (Philippi, 1844) [= Torellia vestita Jeffreys, 1867] - Reported to be found from off Tromsø $\left(69^{\circ}\right.$ $\left.40^{\prime} \mathrm{N}\right)$ south to Stavanger $\left(59^{\circ} \mathrm{N}\right)$ (Bouchet \& Warén 1993). The change of name from $T$. vestita to $T$. delicata is due to Warén (1991:72), who argued that the name Cyclostoma delicata Philippi, 1844, based on a Pliocene-Pleistocene fossil from Sicily, undoubtedly is conspecific with Jeffreys' Torellia vestita. Warén (in Bouchet \& Warén 1993) in addition to a handful of museum specimens, lists eight specimens from six samples just outside Korsfjorden, 250-325 m. In my material an uncommon species. I have four samples of this species, one juvenile shell from the Steinavær coral reef $\left(69^{\circ} 14^{\prime} \mathrm{N}, 370 \mathrm{~m}\right)$, another juvenile from Korsfjorden $\left(60^{\circ} 11^{\prime} \mathrm{N}, 680 \mathrm{~m}\right.$, silt and clay). Two tiny juveniles from west of Rongøy in Øygarden $\left(60^{\circ}\right.$ $30^{\prime} \mathrm{N}, 70-75 \mathrm{~m}$, shell sand), and two adult specimens from Fedjeosen $\left(60^{\circ} 45^{\prime} \mathrm{N}, 220-140\right.$ m, rocky substrate, W. Vader coll., leg. et det.). Finally a fairly large specimen from the outer part of Fensfjorden $\left(60^{\circ} 51^{\prime} \mathrm{N}\right.$, ca. $\left.500 \mathrm{~m}\right)$. From the slope I have a number of juveniles (but only a single adult) from six stations between 602 and $1009 \mathrm{~m}$, with a peak of 12 specimens at $701 \mathrm{~m}$.

Trichotropis spp. - I have found an enormous variability in size and shape of the protoconch which argues for a division of Trichotropis borealis into several species. However, the larvae of otherwise 'typical' T. borealis do vary a lot in size. According to Fretter \& Graham (1981) "The protoconch has c. two whorls marked with first one, then two spiral ridges and already bears a periostracal covering; these features are usually lost in mature shells. ... The veliger stage is passed within the capsule and young emerge as juveniles with a shell of $1+$ whorls, c. $1 \mathrm{~mm}$ in diameter decorated with three spiral ridges and already covered with periostracum." Below I have retained the common form as $T$. borealis, while a deviating form has been split out as Trichotropis n. sp.. Another one is sufficiently distinct for me to provisionally name it $T$. cf. borealis.

Trichotropis borealis Broderip \& G.B. Sowerby I, 1829 Reported to be found along the Norwegian coast from Rogaland and northwards, including East Finnmark (G.O. Sars 1878). Not found by Wikander $(1989,1990)$ on the Skagerak coast. In my material 70 specimens 
(in addition to some 300 shells), the majority found between $65^{\circ}$ and $69^{\circ} \mathrm{N}$, although not uncommon on the other parts of the coast covered. The protoconchs of young $T$. borealis are covered with a diaphanous periostracum elevated somewhat from the calcareous shell, and with two spiral periostracal 'keels'. The periostracal cover usually disappears in shells more than three mm long, but two slightly 'dirtied', slightly elevated spiral 'ridges' often remain, giving the protoconch a bi-angled appearance, with a flattish area between the spirals. None had the numerous fine spiral lines characteristic of $T$. conicus. The diameter of the protoconch is roughly $650-675 \mu \mathrm{m}$.

Trichotropis cf. borealis - A juvenile shell, found together with nine specimens and four shells of T. borealis, in Saltfjorden close to Sandhornøy (67 $10^{\circ}$ N, 170-90 $\mathrm{m}$, Modiolula phaseolina bottom) has a bulbuous protoconch of $1 \frac{1}{2}$ whorls with a diameter of 930-940 $\mu \mathrm{m}$, much larger than any $T$. borealis protoconch I have seen. Like $T$. borealis the protoconch has a narrow 'keel', dirty yellowish brown in colour, along the top of the whorl ending in the apical 'pit'. One or two less distinct ones on the middle and lower part of the protoconch whorls. Unlike T. borealis there is no 'flattish' or even concave area between two keels. Where the teleoconch starts, the narrow keels are continued as three strong spiral cords, the lower one being slightly stronger than the other two. The space between the cords is deep and narrow, narrower than the cords. The periostracum of the teleoconch is dried up, with isolated long tufts of hairs on the topmost spiral cord. The aperture is shorter and less pointed below.

Trichotropis n. sp. - A juvenile completely covered by periostracum, from Silavågen near the mouth of Sjona ( $66^{\circ} 19^{\prime} \mathrm{N}, 20-18 \mathrm{~m}$, very soft muddy bottom) looks different from the 'typical' $T$. borealis. The grayish periostracum is very densely covered with minute hairs, and has a protoconch with fewer, wider whorls (more flattish) than shells of typical T. borealis.

Trichotropis conicus Møller, 1842 - The original spelling as well as most recent usage (e.g. Warén in Sneli et al. 2005) is T. conica, but CLEMAM uses T. conicus. According to Brown (1956) the latin noun 'tropis' is female, and the spelling $T$. conica should be correct. A photograph of a syntype is published in Schiøtte \& Warén (1992). This northern species has been recorded from the Arctic south to roughly $69^{\circ} \mathrm{N}$ on the Norwegian coast (Friele \& Grieg 1901), and recently from $61^{\circ} \mathrm{N}$ on the NW slope of the Faeroe-Shetland Channel, 604 m (Warén in Sneli et al. 2005). In my material one 'typical', and two more questionable samples of this species. A well preserved adult specimen $6.6 \mathrm{~mm}$ long from Gratangen (68 $44^{\prime} \mathrm{N}, 90-80$ $\mathrm{m}$, fine shell sand). This specimen is apparently without periostracum, only with a row of tufts along the outside of the siphonal canal. The protoconch is wide and flat and without periostracum, but with numerous dense spirals. The diameter of this protoconch is $770-780 \mu \mathrm{m}$. A shell from Foldafjorden (64 $40^{\prime} \mathrm{N}$, 60-20 m, shell gravel and lots of tubes of the serpulid Hydroides) also clearly belong to this species. As the shell seemed fairly fresh, this record represents a new southern limit for the species. Two juveniles from the upper slope northwest of Andøya (69 $25^{\prime}$ $\mathrm{N})$ are more questionable. These two juveniles had large but somewhat different protoconchs. One had a protoconch of $1 \frac{1}{2}$ whorls being a little wider than high, covered with more than 18 very fine spiral lines. The other had a more bulky protoconch, but it was rather worn. The former, well preserved, protoconch is distinctly wider than the one of $T$. borealis, and the very fine spiral lines are clearly visible on the glossy protoconch. Another peculiarity is that this protoconch had a very pronounced 'break' at the transition to the teleoconch.

Velutininae - In a series of articles, Gulbin \& Golikov (1997, 1998, 1999, 2000, 2001) have revised the northern and Arctic species of this subfamily (regarded as a family by Gulbin \& Golikov).

Velutina lanigera Møller, 1842 - Revised by Gulbin \& Golikov (1999) who put it in the genus Ciliatovelutina Golikov \& Gulbin, 1990. In Norway reported from Lofoten (c. $68^{\circ} \mathrm{N}$ ) to East Finnmark (Odhner 1913). Not in my material.

Velutina plicatilis (O.F. Müller, 1776) - Revised by Gulbin \& Golikov (2000) who put it in the genus Velutella Gray, 1847. Recorded from the whole coast, but everywhere rare (Odhner 1913). Schneider (1886) reports it as singly between Halocynthia at a specific locality in Tromsøysundet, but never elsewhere in that area. Easily recognized because of its orange red soft parts. Wikander (1990) reports a single specimen from $60 \mathrm{~m}$ depth, southwest of Jomfruland ( $9^{\circ} 29^{\prime} \mathrm{E}$ ). In my material, a single specimen (since dried out) from Korsfjorden, close to Kleppholmen $\left(60^{\circ} 11^{\prime} \mathrm{N}\right.$, 28-32 m, shell sand). Three specimens of Velutina velutina in the same sample.

Velutina schneideri Friele, 1886 - Revised by Gulbin \& Golikov (1999). Described from a single specimen from Tromsø, $37 \mathrm{~m}$. According to Gulbin \& 
Golikov, a predominantly circumpolar, Arctic species. Because of its similarity with Velutina velutina other records from Norway are not reliable. (Odhner 1913 for example did not distinguish it from $V$. velutina). Not in my material.

Velutina undata J. Smith, 1839 [= Velutina undata Brown, 1838] - Revised by Gulbin \& Golikov (1998), who assigned this species to the genus Limneria H. \& A. Adams, 1853, a decision accepted by Schiøtte (in Sneli et al. 2005), but not (yet) by Clemam. Stated to be distributed along the Norwegian coast south to Kristiansund (c. $63^{\circ} \mathrm{N}$ ) (Schiøtte in Sneli et al. 2005). In my material two somewhat degraded shells have been referred to this species, one from Varangerfjorden south of Kiby $\left(69^{\circ} 59^{\prime} \mathrm{N}, 220 \mathrm{~m}\right.$, mud w/Rhabammina and polychaete tubes), and one from Andfjorden, $1 \mathrm{~km}$ east of Andøya (69 $12.5^{\circ} \mathrm{N}$, $125 \mathrm{~m}$, rocky bottom). They are without periostracum, and the lips are slightly broken, but they do have some characteristics distinguishing them from $V$. velutina. Firstly the spiral sculpture is much finer and more irregular than in $V$. velutina, the protoconch is much larger, indicating direct development, the lip is not continuous around the aperture as in $V$. velutina, but has a flat and sharp ledge along the inner side of the body whorl. Also five specimens from four stations on the upper slope, from 543 to $701 \mathrm{~m}$, all in the same transect just north of the Norwegian Trench.

Velutina velutina (O.F. Müller, 1776) - Revised by Gulbin \& Golikov (1999). A common species along all of the Norwegian coast (G.O. Sars 1878). Wikander $(1989,1990)$ reports five samples with one specimen in each from the Skagerrak coast. In my material 67 specimens, of which 18 from the summer cruises. In addition some 100 shells.

Onchidiopsis glacialis (M. Sars, 1851) - Revised by Gulbin \& Golikov (2001). In Norway recorded from several places from Tromsøysundet (c. $69^{\circ} 40^{\prime} \mathrm{N}$ ) to East Finnmark at moderate depths from 30 to $140 \mathrm{~m}$ (Odhner 1913). Not in my material.

Piliscus radiatus (M. Sars, 1851) [= Capulacmaea radiata (M. Sars, 1851)] - Revised in Warén (1989) and again in Gulbin \& Golikov (1997). While Warén could see no reason to keep Pilidium commodus Middendorff, 1851 apart from Capulus radiatus M. Sars, 1851, Gulbin \& Golikov, on the basis of differences in protoconch morphology and disjunct geographical distribution, concluded that two species are involved. This Arctic species is in Norway only known from its type locality, Komagfjord in western Finnmark $\left(70^{\circ}\right.$ $16^{\prime} \mathrm{N}, 23^{\circ} 23^{\prime} \mathrm{E}, 55-75 \mathrm{~m}$, rocky bottom). In addition a few shells and fragments from the slope in negative temperatures from $66^{\circ} 40^{\prime} \mathrm{N}$ to $68^{\circ} 20^{\prime} \mathrm{N}, 640$ and $840 \mathrm{~m}$. Also mentioned from two stations in negative temperatures east of the Faroes by Warén (in Sneli et al. 2005). Not in my material.

Lamellaria latens (O.F. Müller, 1776) - Recorded from Rogaland $\left(59^{\circ} 20^{\prime} \mathrm{N}\right)$ to $71^{\circ} \mathrm{N}$ in western Finnmark (Odhner 1913), but apparently not very common. Described in detail by Fretter \& Graham (1981), and also by Graham (1988). These authors rely on the conclusions of McMillan (1939) that the two shallow water species in our waters, $L$. latens and $L$. perspicua, are valid species. According to Bouchet \& Warén (1993) however: 'The taxonomy of the shallow water representatives of the family [Lamellariidae] is poorly understood.... the distinction between these forms [L. perspicua and L. latens] is problematic and need further attention'. I have 11 specimens in my material, eight of them from the Espegrend area.

Lamellaria perspicua (Linné, 1758) - This is apparently the least common of the two species of Lamellaria found in Norwegian waters, reported from Oslofjorden and Trondheimsfjorden (Odhner 1913, 1926). Also from a small number of poorly documented records north to western Finnmark (Brattegard in Høisæter et al. 1997a). Wikander (1990) reports a single (questionable) juvenile from outside Tromøya $\left(58^{\circ} 25^{\prime} \mathrm{N}, 95\right.$ $\mathrm{m})$. I have only two specimens (dried out) that may safely be assigned to $L$. perspicua, both from an unlabeled sample from the Espegrend area.

Calyptoconcha cf. pellucida (Verrill, 1880) [= Lamellaria pellucida Verrill in Verrill \& Smith, 1882] - C. pellucida was discussed by Odhner (1926) and Bouchet \& Warén (1993). It has been recorded only once from Norway, from Trondheimsfjorden in the 1920's Odhner (1926). Recently (Warén in Sneli et al. 2005) it has also been reported from $358 \mathrm{~m}$ on the northwestern shelf of the Faroes. A single large specimen from a trawl-haul in Korsfjorden $\left(60^{\circ} 11^{\prime} \mathrm{N}, 680 \mathrm{~m}\right.$, $11 / 3$ 1971) agrees fairly well with the description of the species. The main difference between the earlier records and my specimen is the lack of shell in the latter. Dimensions are impressive, 6 x $4.5 \mathrm{~cm}$ overall, and $2.5 \times 1.5 \mathrm{~cm}$ (in alcohol) for the foot. Siphonal canal is directed forwards, over the left tentacle. No lateral canal was found.The colour (in alcohol) completely white, with a very few, scattered grayish spots. Tiny eyes on the outside of the tentacles close to the middle of these. A bundle of tentacle shaped filaments just to the right of the branchium, protruding 
in front of the head. The radula not prepared out, but the pointed ends of two teeth are visible in the mouth opening. They are dark, brownish black, apparently very stout. A renewed inspection of the body inside the mantle shows that it is coiled up in a typical gastropod spiral, but still without any (remaining?) shell, as C. pellucida is supposed to have. According to Bouchet \& Warén (1993): "All animals have the same general appearance, with a thin, fragile (usually broken or decalcified), internal shell."

Marseniella borealis Bergh, 1886 - By some authorities included in Lamellaria (e.g. Smith \& Heppell 1991), but retained as a monotypic genus in CLEMAM. Apparently not refound since it was described from a sample from outside Florø $\left(61^{\circ} 35^{\prime} \mathrm{N}\right)$. Not in my material.

Marsenina glabra (Couthouy, 1839) - Revised by Gulbin \& Golikov (2000). Predominantly Arctic (from Tromsø and northwards) but according to Odhner (1913) in Norway found also near Kvitsøy in Rogaland, and later (Odhner 1926) recorded from Trondheimsfjorden. Not in my material.

Trivia arctica (Pulteney, 1799) - Earlier reported as rare from Oslofjorden and north to Lofoten (G.O. Sars 1878, Soot-Ryen 1951). In my material 11 records north of Hordaland, Fugløyfjord ( $67^{\circ} 01^{\prime}$ N, 70-50 $\mathrm{m}$, small stones and Modiolula shells) being the northernmost. Of these 11 samples only two contained a total of three specimens (out of 27 shells). Only a single shell in the material from Møre og Romsdal. At least 19 specimens from the Espegrend area, and experience from a number of field courses has shown that it is common in this area, although perhaps not every year. There is a slight possibility that also Trivia monacha (da Costa, 1778) is present in Norwegian waters, but no material with three distinct pigment blotches on upper side of shell available for confirmation. Investigation of a larger material might prove that more than one species is present in Norwegian waters as specimens from northern Norway are slightly different from those from the Espegrend area. Width of opening, shape of outer 'lip' and colour pattern of soft parts might be characters of taxonomic importance.

Erato voluta (Montagu, 1803) - According to Hubendick \& Warén (1971) it is found in the Bergen area, but if that is based on empty shells only or living material is not stated. Later (Hubendick \& Warén 1976, repeated in Fretter \& Graham 1981 and Hansson 1998) reported it from the southeastern Norwegian coast, apparently based on material donated by Wikander. Not in my material.

Cryptonatica affinis (Gmelin, 1791) [= Natica clausa Broderip \& Sowerby G.B. I, 1829] - Discussed by Bouchet \& Warén (1993), who are responsible for the name change. According to these authors, distributed from Arctic waters and southwards along the whole of the Norwegian coast and further south, descending into deeper waters from Lofoten (c. $68^{\circ}$ N) southwards. In G.O. Sars (1878) only reported from Lofoten and northwards. Not mentioned in Wikander (1989, 1990). In my material 58 specimens fairly regularly distributed on all investigated parts of the coast.

Cryptonatica bathybii (Friele, 1879) [= Natica bathybii Friele, 1879] - Discussed in Bouchet \& Warén (1979, 1993). Except for a record from $150 \mathrm{~m}$ in East Greenland at $74^{\circ} 35^{\prime} \mathrm{N}$ (Odhner 1913), all reports are from bathyal and abyssal parts of the Nordic Seas. Found by Grieg (1915) on the slope at $800 \mathrm{~m}$ (negative temperature) at 'Tampen' $\left(0^{\circ} 15^{\prime}\right.$ E) and by Sneli (in Sneli et al. 2005) on the slope east of the Faroes at $918 \mathrm{~m}$ at $4^{\circ} 46^{\prime} \mathrm{W}$. All other records are from depths below $1200 \mathrm{~m}$ in the Norwegian Sea (the record from $600 \mathrm{~m}$ attributed to Friele (1903) in Odhner (1913) and Bouchet \& Warén (1979) is due to a misreading of a table). In my material 31 specimens from 11 samples from the lower slope and the abyssal parts of the Norwegian Sea. Three of these specimens are from $1112 \mathrm{~m}$ and $1380 \mathrm{~m}$ respectively, while the remaining 28 all were found deeper than $2000 \mathrm{~m}$. $C$. bathybii thus seems to be a typical abyssal species in the Norwegian Sea, with a few scattered occurrences on the lower slope (in a sample from the ridge south of Jan Mayen, $879 \mathrm{~m}$, seven specimens were found).

Euspira spp. - The classification of the species in this group of North-European naticids is problematical. In recent literature both Polinices and Euspira have been used as names of the genus traditionally called Lunatia. The supraspecific taxonomy of the Naticidae has been thoroughly reviewed by Kabat (1991), and he has demonstrated that Lunatia is a junior subjective synonym of Euspira, which thus has to be used. Bouchet \& Warén (1993) claim to follow Kabat (1991) in restricting the use of Euspira to two species from the Mediterranean and off Mauritania south to Namibia. The remaining species in the group they prefer to put in Polinices, although they admit that the similarities to the typical tropical species in the group are not convincing. Smith \& Heppel (1991) use Euspira as a subgenus of Polinices for 
the British species of the group. Hansson (1998) also treats Euspira as a subgenus of Polinices, but divides the Norwegian species between the two subgenera, pallida in Euspira, and montagui and pulchella in Polinices s.str. In Clemam Euspira is used (probably following Sabelli et al. 1990) as a full generic name for the whole group. The argument is obviously not settled yet.

Euspira montagui (Forbes, 1838) [= Lunatia montagui] - Discussed and compared with other species of the genus (as Polinices montagui) in Bouchet \& Warén (1993). Common all along the coast north to Hammerfest $\left(70^{\circ} 40^{\prime} \mathrm{N}\right)$ (Odhner 1913), at intermediate depths in fine to medium coarse sediment. Odhner (1913) claims that Norman (1902) found it in East Finnmark, but Norman's record is really from Svolvær $\left(68^{\circ} 1^{\prime} \mathrm{N}\right)$. Probably the most common naticid in Norway. Wikander $(1989,1990)$ reports 69 samples with a total of more than 200 specimens from the Skagerrak coast. In my material 132 specimens of which the northernmost from the coral reef at Steinavær in Andfjorden. Further south 70 specimens from Nordland south of Bodø, five from NordTrøndelag (and more than 200 shells), 23 from Møre og Romsdal and 33 from the Espegrend area.

Euspira pallida (Broderip \& Sowerby G.B. I, 1829) [= Lunatia pallida] - For some reason not mentioned in Bouchet \& Warén (1993). Found along the whole coast (Odhner 1913), but more common in the northern part than in the southern part, where it is confined to deeper water. Wikander $(1989,1990)$ reports three samples with one specimen in each (of which two are questionable), from the Skagerrak coast. I have assigned all shells with a 'direct development' protoconch to this species. High variability in this material indicates that several species may be involved. In my material 59 specimens, of which 12 from East Finnmark, only four shells from the Andfjorden series, 21 from Nordland south of Bodø, 11 from Nord-Trøndelag and 10 from Møre og Romsdal. Only five from the Espegrend area. Also a single specimen from the upper slope $\left(62^{\circ} 29^{\prime} \mathrm{N}, 602 \mathrm{~m}\right)$.

Euspira pulchella (Risso, 1826) [= Lunatia alderi (Forbes, 1838)] - Mentioned in passing in Bouchet \& Warén (1993), who is responsible for the name change, based on comparison with Risso's types and a suite of Mediterranean and Atlantic specimens. A common shallow water species in southern Norway and further south, preferring coarse sediment (usually shell sand). Reported to be found north to Lofoten, $68^{\circ}$ N (G.O. Sars 1878; Norman 1902).
Odhner (1913) claims that Norman (1902) found it in East Finnmark, but Norman's record is really from Svolvær (68 $\left.18^{\circ} \mathrm{N}\right)$. Schneider (1886) did not find it in Tromsøysundet. Warén (in litt) mentions a specimen from Stjernsund $\left(70^{\circ} 16^{\prime} \mathrm{N}\right)$ as probably the northern distributional limit. Wikander $(1989,1990)$ reports 87 samples with a total of more than 460 specimens from the Skagerrak coast. In my material only empty shells from north of the Espegrend area, the northernmost from $69^{\circ} 20^{\prime} \mathrm{N}$, in Andfjorden, just east of Andøya. Several shells reported from the intermediate sectors of the coast, nine from Nordland south of Bodø, 15 from Nord-Trøndelag, and eight from Møre og Romsdal. The 127 specimens from around Espegrend were usually yellowish white with characteristic brown markings near the suture. Sometimes almost completely light brown, without the markings, and thus likely to be mistaken for $E$. fusca (Blainville, 1825). This latter, however, is found in somewhat deeper water in the northern North Sea (and further south along the outer coast of the British Isles). E. fusca has never been positively identified from Norwegian material, although Brattegard (in Høisæter et al. 1997a) reports it from sector 4 and 6 , c. $58^{\circ} 15^{\prime} \mathrm{N}$. These records need verification. The two specimens mentioned above without the characteristic markings, are large (close to maximum size reported for the species) and presumably old specimens, both found in samples from very shallow inshore water. One from Grøneviken in Fanafjorden (c. $60^{\circ} 15^{\prime} \mathrm{N}, 10-15 \mathrm{~m}$, muddy sand) was found together with two smaller specimens with typical $E$. pulchella colour pattern.

*Euspira n. sp. - Based on a single shell from Sørfjord (67 03' N, 150-120 m, silt) containing also three specimens of E. montagui and one of E. pallida). Shell fairly worn, and no colour characteristics (uniform grayish white as is most specimens of juvenile $E$. pallida). Protoconch of the direct development type, very flat, appearing almost heterostrophic, flatter and with first 'limb' wider and longer than in E. pallida. May be an aberrant form of E. pallida.

Amauropsis islandica (Gmelin, 1791) - Whole Norwegian coast south to Lindesnes (Sneli in Sneli et al. 2005). In my material sparingly in all sectors except East Finnmark, although only a single specimen in the whole collection, from north of Gjerdingen (64 $4^{\circ} 57.5^{\prime}$ $\mathrm{N}$, outer coast, $80-30 \mathrm{~m}$ ). Ten of altogether 17 shells were found around $64^{\circ}$ to $66^{\circ} \mathrm{N}$.

Bulbus smithi (Brown, 1839) - Found south to Lofoten (c. $68^{\circ} \mathrm{N}$ ) by G.O. Sars (1878). In my material two shells 
from just east of Andøya ( $69^{\circ} 20^{\prime} \mathrm{N}, 80-60 \mathrm{~m}$, coarse shell sand. In addition a shell from Ullsfjorden, $69^{\circ}$ 40’N, 105 m, coll. \& leg. T. Brattegard).

Pseudopolinices nanus (Møller, 1842) [= Lunatia nana (Møller, 1842)] - An Arctic species, in Norway only recorded four or five times from East Finnmark (G.O. Sars 1878, Norman 1902, Odhner 1913). All specimens seem to have been around five to six $\mathrm{mm}$. In my material a single sample of six animals from Småstraumen in Varanger (close to the Russian border at Grense Jacobselv, 4-12 m, sand and shell gravel). The largest of the six specimens is c. 8 $\mathrm{mm}$. The shells are almost pure white, solid (much more than e.g. Cryptonatica affinis), the umbilicus is completely closed by a callus which continues up along the inner lip as a heavy 'thickening' of the lip. The thickened outer lip meeting the body whorl at a very acute angle. Body whorl dominating more than in other species, so that the spire is inconspicuous. Suture indistinct, the whorls merging gradually into each other. Fits fairly well the illustration in Bouchet \& Warén (1993: Fig. 1952). The illustrated Arctic specimen is only $5.5 \mathrm{~mm}$, and have a somewhat more open umbilicus. This also applies to the description and drawing in G.O. Sars (1878), whose single specimen from East Finnmark also measured $5.5 \mathrm{~mm}$. A problem is that the photograph of the lectotype in Schiøtte \& Warén (1992: Fig. 12, $6.5 \mathrm{~mm}$ ), is not very similar. Odhner (1913) reports some variation both in the shell colour and the relative height of the spire.

Nucella lapillus (Linné, 1758) - This common littoral form is found along the whole coast, including Oslofjorden (G.O. Sars 1878). The populations on the Skagerrak coast seems to have recovered well after the catastrophic mass-death in the Chrysochromulina episode in 1988 (Wikander in litt.). Not mentioned in Wikander $(1989,1990)$ however, but this was due to lack of collection efforts in the rocky intertidal (Wikander in litt.). For the same reason only occasional shells in my material.

TrophoninaE Cossman, 1903 - The nomenclature as well as the phylogeny within this subfamily of Muricidae is far from settled. I follow CLEMAM in naming the species with a predominantly southern distribution Trophonopsis, those with a mainly boreal distribution Boreotrophon, and the single Arctic species that might possibly be found in Norwegian waters, Scabrotrophon. Bouchet \& Warén (1985), however have argued for the retention of Trophon as genus name for the whole group of Norwegian species. This usage has been adopted by Rosenberg (2005). According to
Kool (1993) (see also Watters 2007) the type species of Trophon from southern South America is closely related to Ocenebra, the type genus of Ocenebrinae, and this species might thus be more closely related to Ocenebra than to most species otherwise included in TrophoninaE. Watters (2007) also comments that there is no agreement on the placement of species in Trophonopsis versus Boreotrophon. If the two genera should be amalgamated, Trophonopsis (type species Murex muricatus from Britain) has priority. Smith \& Heppell (1991), based on Houart (1981), use Boreotrophon and Trophonopsis, but includes B. clavatus in Trophonopsis together with T. barvicensis. The whole subfamily is urgently in need of revision preferably based on molecular genetic data. The Norwegian species of the group have been treated by Bouchet \& Warén (1985), and I follow their interpretation of the species.

Trophonopsis barvicensis (Johnston, 1825) - The most common species in this group in Norway south of Lofoten. Reported from the entire coast with the exception of East Finnmark (Bouchet \& Warén 1985). Wikander $(1989,1990)$ reports eight samples with a total of more than 26 specimens from the Skagerrak coast. In my material altogether 205 specimens, gradually decreasing in abundance northwards. North of Lofoten I have eight specimens from four samples in the Gratangen - Grovfjord area (c. $68^{\circ} 40^{\prime} / 45^{\prime} \mathrm{N}$ ). One of these is a specimen $13.5 \mathrm{~mm}$ long (unusually long for the species) from the mouth of Grovfjord $\left(68^{\circ} 43^{\prime} \mathrm{N}, 325-300 \mathrm{~m}\right.$, mud) with well drawn out spiny projections. Further south the species seems to be especially numerous in the Møre og Romsdal region, with altogether 60 specimens from 13 stations. Most of these were taken from sandy bottoms at depths from 60 to $220 \mathrm{~m}$.

Boreotrophon spp. - The three species in this genus are variable, and with partly overlapping shell characters, thus the identifications below are tentative whenever based on old and worn shells.

Boreotrophon clathratus (Linné, 1767) [= Trophonopsis clathratus] - Following Bouchet \& Warén (1985), I have used the shape of the protoconch as the main character for distinguishing between $B$. clathratus and $B$. clavatus. While the larval shell of $B$. clavatus is round that of $B$. clathratus is angulated (often partly eroded, however). B. clathratus is an Arctic, shallow water species going south to the Lofoten area, while $B$. clavatus is a boreal species occurring at intermediate depths (roughly 100-200 m), and not previously found north of Lofoten. In my 
material the most 'typical' sample of B. clathratus is one from Kvæfjorden ( $68^{\circ} 50^{\prime} \mathrm{N}, 30 \mathrm{~m}$, dense algal vegetation) of four specimens, all with very well preserved protoconchs. One of two specimens from Ellingsøyfjorden $\left(62^{\circ} 28^{\prime} \mathrm{N}, 52-44 \mathrm{~m}\right.$, sand $)$ is a giant, at least $25 \mathrm{~mm}$ long and fitting the description of G.O. Sars' var. gunneri with the apex eroded away, the other a smaller specimen but with very well preserved protoconch. They represent a southerly distributional extension by a wide margin. A rather confusing sample that I provisionally have included in this species, is one from Bugøyfjorden, SørVaranger $\left(69^{\circ} 52^{\prime} \mathrm{N}, 100-0 \mathrm{~m}\right.$, steep rocky wall), with six rather large, up to around $22 \mathrm{~mm}$ long, specimens. These are peach-coloured, with the inner wall of the aperture orange. Unfortunately the protoconchs are mostly eroded, but the shells, including the upper whorls, appear much more coarse than in any other samples seen. In the most well preserved shells the siphonal canal is elegantly curved like in B. truncatus (Fig. 282 in Bouchet \& Warén 1985), but the number of axial costae is lower, and the shell is larger than my samples of $B$. truncatus (supposed to not exceed 15 $\mathrm{mm})$. No sign of any incipient spiny processes on the axial costae in any of the six shells. A final possibility is that this sample may represent the high Arctic Scabrotrophon fabricii, which has been reported as a doubtful species from East Finnmark (cf. G.O. Sars 1878). Including this somewhat deviating sample, I have five samples available for verification, one from each of the East Finnmark-, Andfjorden- and Møre og Romsdal-series, and two from the Nordlandseries, the latter with shells only. According to my original identifications there are 13 samples from East Finnmark and nine from the Andfjorden area in my material, testifying to the comparative commonness of this species north of Lofoten.

Boreotrophon clavatus (G.O. Sars, 1878) [= Trophonopsis clavatus] - B. clavatus is one of two species of this group with rounded larval shell, the other being $T$. barvicenisis. Young specimens of the two species might be misidentified, as B. clavatus sometimes has weak spiral ornamentation. The larval shell of $T$. barvicensis is somewhat flatter and with very fine spiral striation, not visible on the protoconch of $B$. clavatus, and the whole juvenile shell is more squat. The spiral ornamentation is also much more distinct. No reliable records from Norway north of Lofoten (G.O. Sars 1878), although in Brattegard (in Høisæter et al. 1997a) there is a record from his sector 22, which has its southern limit at c. $70^{\circ} 20^{\prime} \mathrm{N}$. In my material $B$. clavatus is far more common than $B$. clathratus, also in northern Norway from Lofoten and southwards. In the material from north of Lofoten I have problems in distinguishing both between $T$. barvicensis and $B$. clavatus and between the latter and B. clathratus. I have one sample from Varangerfjorden close to its southern shore $\left(70^{\circ} 01^{\prime} \mathrm{N}, 100 \mathrm{~m}\right.$, muddy sand with gravel and pebbles) with one specimen (and a rather worn empty shell) between 12 and $13 \mathrm{~mm}$ long, unfortunately without protoconch. This looks very much like the specimen illustrated in Fig. 287 in Bouchet \& Warén (1985). I thus, somewhat hesitantly, extend the northern distribution of this species to also encompass East Finnmark. A sample of four somewhat smaller specimens with well preserved protoconchs from the species rich station at Furås in Gratangen ( $68^{\circ} 44^{\prime} \mathrm{N}, 90-80 \mathrm{~m}$, fine shell sand with lots of Modiolula phaseolina) is closer to their Fig. 287 than to any other photographs in Bouchet \& Warén (1985). Further south in my material seven samples from the Nordland-series, 13 from NordTrøndelag (of which one with a specimen around 21 mm long), two from Møre og Romsdal, and four from the Espegrend area.

Boreotrophon truncatus (Strøm, 1768) [= Trophonopsis truncatus] - According to Bouchet \& Warén (1985), this species is distinguished from $B$. clathratus by a rounded larval shell and low, crowded axial lamellae that never form spiny projections. The numerous rather flattened axial lamellae is the most useful criterion. The siphonal canal is comparatively short, straight and wide. By G.O. Sars (1878) stated to be very common in northern Norway but extremely rare in western Norway. Friele (1874) and Norman (1879) report several finds in the Bergen region, but these may have been based on varieties of $B$. clavatus. Norman (1893) reports one shell from $40 \mathrm{~m}$ at Rødberg in Trondheimsfjorden. In my material only two samples: one specimen from Magerøysundet $\left(70^{\circ} 56^{\prime} \mathrm{N}, 45-50 \mathrm{~m}\right)$, and a sample of two specimens and four shells from Kjøfjord, Sør-Varanger (69 48'N, 18-25 m, Lithothamnion and other algae).

*Scabrotrophon fabricii (Møller, 1842) [= Trophonopsis fabricii] - Illustrated and briefly discussed in Bouchet \& Warén (1985). This strictly Arctic species (also known from Iceland) has not been verified to be part of the Norwegian fauna. G.O. Sars (1878) just repeats a record from MacAndrew and Barrett which is rather dubious. The record in Friele (1874) of a large shell from Herdlafjorden $\left(60^{\circ} 35^{\prime} \mathrm{N}\right)$ is also doubtful, although it is not inconceivable that it is a subfossil. Not in my material. 
Metzgeria alba (Wyville-Thomson, 1873) [= Metzgeria albella (Dunker \& Metzger, 1874)] - Reported from the whole Norwegian coast south to Vest Agder county (Sneli in Sneli et al. 2005). Bouchet \& Warén (1985) indicate that the species is rare everywhere within its distributional area except perhaps along the west coast of Norway. In my material seven well preserved specimens from different places along the west coast (from $60^{\circ} 30^{\prime} \mathrm{N}$ to $69^{\circ} \mathrm{N}$ ). In addition a number of shells of poor quality.

Volutomitra groenlandica (Møller, 1842) - Illustrated and discussed in Bouchet \& Warén (1985). G.O. Sars (1878) reported a single specimen from Tromsøflaket $\left(c .70^{\circ} \mathrm{N}\right)$ and another three specimens from outside Måløy $\left(61^{\circ} 55^{\prime} \mathrm{N}\right)$ both from 150-180 m. Apparently not reported from Norway since. Not in my material.

Buccinum spp. - Considering that 13 species has been listed in my check-list (Høisæter 1986), and 22 are listed as valid in CLEMAM, the diversity in my material is surprisingly low. The taxonomic status is far from settled. Smith \& Heppell (1991) list six species names, including B. cyaneum, B. finnmarkianum and $B$. hydrophanum as possible synonyms of $B$. undatum. Sneli (in Sneli et al. 2005) recognize B. cyaneum and $B$. hydrophanum as valid species. In Alexeyev (2003) 46 species are recognized as valid members of the Russian fauna. With the exception of a few deep water forms, all the potential species are extremely variable, and with a large enough material the different forms are all found to be approaching and partly overlapping each other in shell morphology.

Buccinum cyaneum Bruguière, 1792 [including B. undulatum Møller, 1842] - The main difference from 'typical' B. undatum is the lack of axial sculpture (except for very short-lived ones near the suture on whorl no. three on the smallest specimens). Growth lines crossing the undulating spiral sculpture gives the shell a reticulated appearance. G.O. Sars (1878) reports this species to be extremely common in the stony and gravelly littoral around all the coasts of Finnmark, but never found in deeper waters. In the literature reported to be found south to Lofoten (Sneli in Sneli et al. 2005). Surprisingly not found in my material at all.

Buccinum finmarkianum Verkrüzen, 1875 [= Buccinum finmarchianum Verkrüzen, 1875] - According to G.O. Sars (1878) rather common along the coasts of Finnmark from 90-180 m, and a single small specimen from as far south as Lofoten. In my material, three shells from the series from East Finnmark have been identified as $B$. finmarkianum. One specimen from outer Neidenfjorden (69 $49^{\prime} \mathrm{N}, 64-60 \mathrm{~m}$, silty sand, stones, gravel), the two others (shells) not refound. Except for the broken aperture, due to thin regrowth after an earlier accident, the refound specimen was very similar the 'forma typica' of G.O. Sars (1878). One specimen and one shell from the upper slope $\left(62^{\circ} 30^{\prime} \mathrm{N}, 602-604 \mathrm{~m}\right)$.

Buccinum humphreysianum Bennett, 1824 - Previously recorded from the whole coast (Bouchet \& Warén 1985, and Warén in Sneli et al. 2005). According to G.O. Sars (1878) only found in western Finnmark and on the west coast. I have not found any newer published records from Norwegian waters (not mentioned in Norman 1893, 1902) although Brattegard (in Høisæter et al. 1997) reports it in eight of his sectors from eastern Skagerrak to western Finnmark. In my material only five samples with a total of nine specimens, all from the Espegrend area.

Buccinum hydrophanum Hancock, 1846 - According to Nordgaard (1918) this species is occasionally found as far south as Trondheimsfjorden, and on the slope south to $62^{\circ} \mathrm{N}$. In my material one specimen from the upper slope $\left(62^{\circ} 35^{\prime} \mathrm{N}, 656 \mathrm{~m}\right)$ and five specimens and five shells from seven samples from East Finnmark (4 specimens from around $300 \mathrm{~m}$ and one from $425 \mathrm{~m}$ ). This seems to be a species mainly found in deeper waters in Varangerfjorden, although some of the empty shells were from shallow water in the fjords of Sørvaranger.

Buccinum kjennerudae Bouchet \& Warén, 1985 (= Buccinum sulcatum Friele, 1882, not Born, 1778) - In Norway only known from Friele's type material from the slope at $69^{\circ} 46^{\prime} \mathrm{N}, 1187 \mathrm{~m}$. Not in my material.

Buccinum nivale Friele, 1882 - Described and discussed in Warén (1993). In Norway apparently only known from a single juvenile taken by the Norwegian North Atlantic Expedition from the slope at $68^{\circ} 21^{\prime} \mathrm{N}, 836$ $\mathrm{m}$ (Friele 1882), and one specimen from $68^{\circ} 35.5^{\prime} \mathrm{N}$, 850-695 m (Warén 1993). Not in my material.

Buccinum oblitum Sykes, 1911 - Described from a shell from $1100 \mathrm{~m}$ at the southern end of the Faroe-Shetland Channel. Later found alive in several samples from around the Faroes, especially on the western shelf and slope between 100 and $1100 \mathrm{~m}$, and a single shell from off Korsfjorden (see Bouchet \& Warén 1985:189, and Warén in Sneli et al. 2005). In my material a specimen from the slope at $502 \mathrm{~m}\left(62^{\circ} 28^{\prime}\right.$ 
$\mathrm{N})$, and a shell from the slope station in Bleiksdjupet, northwest of Andenes, 700-200 m. This report is thus a confirmation of its presence in Norwegian waters.

*Buccinum scalariforme Møller, 1842 - According to Odhner (1915) (as B. tenue Gray) this Arctic species has been recorded from 9-27 $\mathrm{m}$ at Karlsøy in northern Troms county $\left(\mathrm{c} .70^{\circ} \mathrm{N}\right)$. The record is obviously from the same sample as the one mentioned for Aartsenia candida (Møller, 1842) below. I have not been able to trace the origin of this record, probably from the collections in the Swedish National Museum, Stockholm, and am inclinded to regard it as a case of misplaced labels. Warén (in Hansson 1998) claims that it is not a part of the Norwegian fauna. Not in my material.

Buccinum tumidulum G.O. Sars, 1878 - Described by G.O. Sars from four specimens from around Vadsø in Varangerfjorden, East Finnmark. Since reported by Norman (1902) also from Varangerfjorden. Norman regarded it as a variety of $B$. hydrophanum, however. Recognized as a good species by Warén (1989a), and also by Clemam. Not in my material.

Buccinum undatum Linné, 1758 - This extremely variable species is common along the whole coast. Discussed in Bouchet \& Warén (1985), where the lower depth limit is given as $500 \mathrm{~m}$. Wikander $(1989,1990)$ reports 31 samples with a total of 79 specimens from the Skagerrak coast. In my material 208 specimens, 161 of which are (mainly) juveniles from the Espegrend area. The rest are evenly distributed on the other sectors except East Finnmark where only shells were found.

Beringius turtoni (Bean, 1834) [including B. ossiania (Friele, 1879)] - Although B. ossiania is recognized as a valid species by Clemam, I agree that it should be lumped with B. turtoni (Bouchet \& Warén 1985, Warén \& Smith 2006). It is reported from the entire coast at least as far south as Bergen, further south in the deeper parts of the North Sea (Bouchet \& Warén 1985). In western Norway where it is not uncommon on steep rocky slopes from $200 \mathrm{~m}$ and down, it is competing with Neptunea despecta as being the largest shelled gastropod, reaching a length of at least 15 $\mathrm{cm}$. In my material one sample of three specimens from East Finnmark, one from Glomfjord and one from Nord-Trøndelag identified as B. turtoni. Finally two samples from East Finnmark and one from NordTrøndelag identified as B. ossiania.
Colus gracilis (da Costa, 1778) [including C. glaber (Kobelt, 1876)] - Because of the convincing synonymizing of the two by Bouchet \& Warén (1985) I accept that $C$. glaber and C. gracilis are varietis of one species. Clemam, however, still operates with two species. According to Sneli (in Sneli et al. 2005) found along the whole Norwegian coast from the Arctic south to Kattegat. However in G.O. Sars (1878) only south to the west coast, and not mentioned in Wikander $(1989,1990)$. In my material from East Finnmark four shells, in the Andfjorden-series one specimen and at least eight shells, from Nordland south of Bodø three specimens and two shells, from Nord-Trøndelag four shells, and from Møre og Romsdal two shells. Finally 15 specimens from the Espegrend area also belong to $C$. gracilis. Altogether probably the commonest species of Colus in Norwegian waters, occurring on hard bottom at depths from c. $30 \mathrm{~m}$ to at least $150 \mathrm{~m}$, often on Lophelia rubble.

Colus holboelli (Møller, 1842) [= Colus tortuosus (Reeve, 1855)] - Discussed by Bouchet \& Warén (1985) who are responsible for the name change. Found in numerous locations around the Faroes, in depths from 70-1150 m, fine sand and gravel (Warén in Sneli et al. 2005). Recorded in Norway from intermediate depths (50-150 m) in northern Norway, and in deeper water $(600$ to $1200 \mathrm{~m})$ on the slope south to $61^{\circ} \mathrm{N}$ (according to Warén in Sneli et al. 2005, in Norway south to Fensfjorden, $60^{\circ} 50^{\prime} \mathrm{N}$ ), apparently mostly in/on silt and clay. In my material two shells from East Finnmark, 60-65 m, substrate mainly Arctica islandica shells. In addition an egg capsule presumably belonging to this species, from Varangerfjorden c. $300 \mathrm{~m}$, muddy sediment. Also seven specimens from three stations on the upper slope from 602 to $830 \mathrm{~m}\left(62^{\circ} 30^{\prime} \mathrm{N}\right.$ to $\left.63^{\circ} 10^{\prime} \mathrm{N}\right)$.

Colus islandicus (Mohr, 1786) $[=$ Colus islandicus (Gmelin, 1791)] - Discussed by Bouchet \& Warén (1985), who are responsible for the change of author name. Recorded from the entire Norwegian coast at least south to Lindesnes and the outer parts of Skagerrak, on the shelf and upper slope (Sneli et al. 2005). In my material two shells from around $62^{\circ}$ $30^{\prime} \mathrm{N}$, one specimen from around $67^{\circ} \mathrm{N}$, and finally one specimen together with several shells from East Finnmark, all from intermediate depths, the ones from Varangerfjorden were found deepest at $225 \mathrm{~m}$. I also have a specimen from a sample from the ridge south of Jan Mayen, $879 \mathrm{~m}$.

Colus jeffreysianus (P. Fischer, 1868) - Listed under the name Sipho propinquus (Alder, 1848) from the west- 
ern coast of Norway, c. 200 m, by G.O. Sars (1878). Otherwise fairly common in the North Sea and SW Skagerrak and Kattegat (Bouchet \& Warén 1985). Not in my material.

Colus latericeus (Møller, 1842) - This coast and shelf species has been discussed by Bouchet \& Warén (1985). In Norway only recorded from northern Norway, south to $69^{\circ} 30^{\prime} \mathrm{N}$ (Sneli et al. 2005). In the Faroes found along the northern and eastern slope in negative temperatures, from 500 to $800 \mathrm{~m}$, coarse gravel (Warén in Sneli et al. 2005). In my material a single specimen from $175 \mathrm{~m}$, fine sand, in outer Varangerfjorden, c. $70^{\circ}$ N. Six specimens from two stations at c. $600 \mathrm{~m}$ just north of the Norwegian Trench $\left(62^{\circ} 30^{\prime}\right.$ N) might also belong to this species.

Colus sabini (J.E. Gray, 1824) [= C. ebur (Mørch, 1869)] - This synonymy (also followed by CLEMAM) is due to Bouchet \& Warén (1985) who, however, complicate things by stating that the species is absent from Norwegian waters, citing Friele (1882). Friele, however, reported $C$. ebur from two stations in Norway, Tanafjorden at c. $70^{\circ} 47^{\prime} \mathrm{N}$, and the shelf outside Kristiansund at $63^{\circ} 10^{\prime} \mathrm{N}, 180 \mathrm{~m}$. Friele \& Grieg (1901) state that it is found along the whole Norwegian coast at least from $58^{\circ} 30^{\prime} \mathrm{N}$ to East Finnmark. It is possible although not stated explicitly, that Bouchet \& Warén (1985:232) regard Friele's C. ebur as a synonym of Turrisipho moebii. Warén (in Sneli et al. 2005) reports it from two stations in negative temperatures, 800 and $1000 \mathrm{~m}$, in the Faroe-Shetland Channel, and Sneli (in Sneli et al. 2005) gives the general distribution to be the Arctic and the Norwegian Sea south to the North Sea and Skagerrak. In my material one possible specimen from the upper slope ( $\left.62^{\circ} 59^{\prime} \mathrm{N}, 804 \mathrm{~m}\right)$.

Colus turgidulus (Friele, 1877) [= C. turgidulus (Friele, 1877 ex Jeffreys MS)] - Discussed and illustrated in Bouchet \& Warén (1985). Distributed along the slopes of the Norwegian Basin, from 400 to $1100 \mathrm{~m}$. In my material four specimens and one shell from four stations on the upper slope, from 701 to $804 \mathrm{~m}$.

Colus verkruezeni (Kobelt, 1876) - Described from Porsangerfjorden in Finnmark (most likely from the inner part with negative temperatures, at c. $70^{\circ} 15$, N). Also recorded by Friele \& Grieg (1901) under the name Sipho virgata Friele, 1879, from the slope $\left(66^{\circ} 41^{\prime} \mathrm{N}\right), 640 \mathrm{~m}$, negative temperature. Not in my material.
Liomesus ovum (Turton, 1825) [including L. eburneum (G.O. Sars, 1878)] - Discussed in Bouchet \& Warén (1985) who synonymizes L. eburneum with L. ovum. The northern limit in Norwegian waters is stated to be Lofoten and Vestfjorden, around $68^{\circ} 10^{\prime} \mathrm{N}$ (G.O. Sars 1878, who also reports it from the west coast). Brattegard (in Høisæter et al. 1997a) includes a record from his sector 22, with a southern limit of roughly $70^{\circ} 10^{\prime} \mathrm{N}$. According to Bouchet \& Warén, the species is normally restricted to depths of more than $100 \mathrm{~m}$ on the shelf. Although not stated explicitely, the impression is that this is a rare species on the Norwegian shelf. Only two specimens in my material, both from two dredge hauls from the same locality, east of Fiskenes on Andøya, Andfjorden $\left(69^{\circ} 16^{\prime} \mathrm{N}, 60-80 \mathrm{~m}\right.$, coarse shell sand and larger shell fragments). In both dredge hauls a single specimen was found.

*Mohnia danielsseni (Friele, 1879) [= Tacita danielsseni] - Confined to the abyssal parts of the Nordic Seas (between Norway and Greenland). In addition to the information in Bouchet \& Warén (1979), some additional illustrations and distribution records in Bouchet \& Warén (1985). Not yet reliably reported from the slope outside Norway, although Grieg (1915) reported two fragments from $1400 \mathrm{~m}$ just north of 'Tampen' (62 $\left.12^{\circ} \mathrm{N}\right)$. In my material two samples with altogether 48 specimens from five stations all deeper than $2400 \mathrm{~m}$.

Mohnia glypta (Verrill, 1882) - Described from off New Jersey at $450 \mathrm{~m}$ and since reported from along the upper slope north to south of Iceland (Bouchet \& Warén 1985). Warén (in Sneli et al. 2005) extended the distribution to also encompass the upper slope north of the Faroes, at 509 and 675 m. A shell (det. Sneli) from the same general area but somewhat deeper turned up in the material from NTNU. In my material two specimens from each of two stations on the upper slope, at 543 and $701 \mathrm{~m}$ respectively, from just north of the Norwegian Trench.

Mohnia mohni (Friele, 1877) - Confined to the abyssal and lower bathyal parts of the Nordic Seas (between Norway and Greenland) where it is the dominating buccinid species. In addition to the information in Bouchet \& Warén (1979) some illustrations and distribution records in Bouchet \& Warén (1985). Shallowest record from $1160 \mathrm{~m}$ on the slope outside Lofoten, $68^{\circ} 06^{\prime} \mathrm{N}$. Abundant in the NTNU material. In my material altogether 291 specimens, the large majority from deeper than $2000 \mathrm{~m}$, but altogether five specimens from the upper slope, at 701, 804 and 
$984 \mathrm{~m}$ respectively. Usually the most abundant species in the deepest parts of the Norwegian Sea.

*Neptunea antiqua (Linné, 1758) - According to Clemam the two forms found in our waters are both valid species (N. antiqua is a 'southern' form, and $N$. despecta a 'northern' one). Usually the two are distinguished on the much more distinct spiral ornamentation on N. despecta. According to Sneli (in Sneli et al. 2005) found in fairly shallow waters in the Faroes, and in the North Sea and around the British Isles and Ireland. Uncertain if it (still) occurs in Norwegian waters, although G.O. Sars (1878) in his distribution tables lists it from the western and southern coasts as well as from Oslofjorden, and Norman (1893) reports one shell from Trondheimsfjorden. Not mentioned in Wikander $(1989,1990)$. Not in my material.

Neptunea despecta (Linné, 1758) - World distribution outlined in Sneli et al. (2005). Common in northern Norway, becoming gradually less common on the shelf further south on the coast, but still present in Skagerrak. Wikander $(1989,1990)$ found four specimens outside Grimstad and Arendal. Also recorded from Oslofjorden (G.O. Sars 1878). In my material 32 specimens, the majority from Nord-Trøndelag and southern Nordland, the southernmost from c. $63^{\circ}$ $48^{\prime} \mathrm{N}$ (Valsfjorden, 68-60 m). Also a shell from Lurefjorden, $60^{\circ} 40^{\prime} \mathrm{N}$, c. $5 \mathrm{~m}$.

Troschelia berniciensis (King, 1846) - The systematic placement of this species is discussed in Bouchet \& Warén (1985), who moved it from Fasciolariidae (preferred by G.O. Sars 1878) to Buccinidae. Found along the continental shelf and upper slope and also in the deeper fjords in Norway from East Finnmark south to at least the Bergen area. Also recorded from the western North Sea and around the Faroes (Schiøtte in Sneli et al. 2005). In my material a single specimen from Foldafjorden (64 41' N, 200-120 m) and three specimens from the Espegrend area, one of which is from 680 m, silt and clay in Korsfjorden.

Turrisipho dalli (Friele in Tryon, 1881) [= Colus (Turrisipho) dalli (Friele, 1882)] - Illustrated and discussed in Bouchet \& Warén (1985). Described from four shells from the Barents Sea, midway between Bear Island and Norway. Since recorded from Varangerfjorden (one shell, leg. G.O. Sars), and from numerous localities around the Faroes, from 370 to $643 \mathrm{~m}$ (Warén in Sneli et al. 2005). In my material a single, freshlooking shell, with periostracum intact, from outside Korsfjorden $\left(60^{\circ} 08^{\prime} \mathrm{N}, 260-250 \mathrm{~m}\right.$, sand, gravel, sponges, serpulid tubes, coll. \& leg. A. Warén).
Warén (in Bouchet \& Warén 1985) reports the find of one specimen and 10 shells from the same general area, $250-325 \mathrm{~m}$. In addition I have three specimens from a sample at $1115 \mathrm{~m}$ on the slope at $62^{\circ} 55^{\prime} \mathrm{N}$, that most probably belong to this species.

Turrisiphofenestratus (Turton, 1834) $[=$ Colus (Colicryptus) fenestratus] - Illustrated and discussed in Bouchet \& Warén (1985). According to Sneli et al. (2005) known from the whole Norwegian coast, but no published records from Finnmark or the coast south of $60^{\circ} \mathrm{N}$. This is the commonest species of the genus on the Norwegian coast. In my material two specimens from Nordland south of Bodø, and three from Møre og Romsdal, as well as eight from the Espegrend/ Herdla area. One large (around $35 \mathrm{~mm}$ long), and well preserved specimen from Bleiksdjupet, northwest of Andenes $\left(69^{\circ} 25^{\prime} \mathrm{N}, 700-200 \mathrm{~m}\right.$, silty sand with small stones and clay) the only shell from north of Bodø, diverges somewhat from the 'typical' form. The specimen is pure white, and with well developed, hairy periostracum. The axial 'folds' are fewer than in most specimens from more southern waters, and they disappear gradually on the body whorl.

Turrisipho lachesis (Mørch, 1869) [= Colus (Turrisipho) lachesis; including Colus (Turrisipho) undulatus (Friele in Tryon, 1881)] - This species has not been reported from Norwegian inshore waters before, but has been found on the slope in negative temperatures as far south as $62^{\circ} 44^{\prime} \mathrm{N}(600-850 \mathrm{~m})$, and in shallower waters in the Barents Sea from $72^{\circ}$ to around $76^{\circ} \mathrm{N}$ (Friele \& Grieg 1901 and Bouchet \& Warén 1985). In my material a single specimen from Varangerfjorden, SE of Bugøya $\left(69^{\circ} 58^{\prime} \mathrm{N}, 29^{\circ} 50^{\prime}\right.$ E, c. $300 \mathrm{~m}$, silt and clay). The specimen found is around $35 \mathrm{~mm}$ long, with well preserved, hirsute periostracum. No vertical sculpture (i.e. undulating ribs) so it does not belong to the variety 'undulatus' which Bouchet \& Warén (1985) has synonymised with T. lachesis, but which is kept as a separate species in Clemam. In addition an egg capsule with fully developed and well preserved larva which most likely belong to this species, from the middle of Varangerfjorden $\left(69^{\circ} 58^{\prime} \mathrm{N}\right.$, $305 \mathrm{~m}$, mud, stones and lots of Rhabdammina foraminiferans). However, the species proved to be rather frequent in my samples from the slope, and occurred with nine specimens in seven samples from the upper slope and three specimens from three samples from the lower slope. Most of the samples were from the transect just north of the Norwegian Trench, from $543 \mathrm{~m}$ (shell only) to $1112 \mathrm{~m}$. Living specimens from $602 \mathrm{~m}$ to $1030 \mathrm{~m}$. 
Turrisipho moebii (Dunker \& Metzger, 1874) [= Colus (Siphonorbis) ebur sensu Friele (1877) and C. (S.) sarsii (Jeffreys, 1869)] - See Bouchet \& Warén (1985) for illustration and nomenclature. Distributed along the whole coast from East Finnmark to at least Lista on the southern coast (originally described from 195 m outside Lista, around $06^{\circ} 40^{\prime} \mathrm{E}$ ). In my material four specimens and an additional 10 shells, mostly from between $63^{\circ}$ and $67^{\circ} \mathrm{N}$.

Turrisipho voeringi (Bouchet \& Warén, 1985) - This was introduced as a new name for Neptunea (Siphonorbis) lachesis var. bicarinata Friele, 1879. Not included in my 1986 checklist, although reported already by M. Sars from Vadsø (Friele \& Grieg 1901). Illustrated and briefly described in Bouchet \& Warén (1985) in which also the distribution was extended to encompass the middle and upper slope north of the Faroes and east of Iceland. One specimen (det. Sneli) from the slope, in the NTNU collection. In my material one specimen from $984 \mathrm{~m}$ at $62^{\circ} 35^{\prime} \mathrm{N}$, just off the Norwegian Trench.

Volutopsius norwegicus (Gmelin, 1791) - See Bouchet \& Warén (1985) for illustration and discussion. Found on the shelf and upper slope all along the coast south to Møre og Romsdal and into the North Sea (Sneli in Sneli et al. 2005). In my material a shell from Glomfjorden $\left(66^{\circ} 48^{\prime} \mathrm{N}\right)$ and a specimen from Kvæfjord ( $68^{\circ} 58^{\prime} \mathrm{N}, 63-75 \mathrm{~m}$, rocky bottom). Also several shells from East Finnmark. A postlarva of impressive size, with a diameter of $7 \mathrm{~mm}$ and at least $9 \mathrm{~mm}$ long may belong to this species, although Fretter \& Graham (1985) report the size of the protoconch to be 4 to $4.5 \mathrm{~mm}$ in diameter and $3 \mathrm{~mm}$ in length. Warén (in litt.) however reports the size of a postlarva to be approximately 7 x $9 \mathrm{~mm}$.

Nassarius spp. - While ClEmam uses Nassarius (with the Indo-West Pacific $N$. arcularius as type species) as name for all but four of the some 30 species in the family found in European (mainly Mediterranean) waters, others use Hinia as generic name for the three recognised north European species (e.g. Smith \& Heppell 1991; Warén in Hansson 1998). Van Aartsen et al. (1984) remark that for purely conchological reasons they regard Hinia (with $N$. reticulatus as type species) as a subgenus of Nassarius. It seems that whenever more than two or three species of this particular subfamily of Nassariidae are found in the same region, it is virtually impossible to convincingly partition the species into separate genera based on conchological characters. Thus all three (or 4) north European species are known from the
Mediterranean, and all experts on Mediterranean molluscs include $N$. incrassatus, $N$. nitidus/reticulatus and N. pygmaeus in Nassarius together with 26 other species not found further north in the Atlantic. Hinia has been retained as one of 11 subgenera by e.g. Gianuzzi-Savelli et al. (2003).

Nassarius incrassatus (Strøm, 1868) [= Hinia incrassata] - This is a very common species in Norwegian waters, by G.O. Sars (1878) reported to be found north to Hammerfest in West Finnmark (70³0’ N), although less common there than in the Lofoten area and further south. Apparently not reported from East Finnmark. Wikander $(1989,1990)$ reports 19 samples with a total of 72 specimens from the Skagerrak coast. In my material I found a single specimen from north of Lofoten, from Stornes on Hinnøya, (68 $51^{\circ}$ $\mathrm{N}, 10 \mathrm{~m}$, rock with algae). Further south hundreds of shells but only a dozen or so specimens south to $62^{\circ}$ $\mathrm{N}$. In the Espegrend area at least 460 specimens in 24 samples.

Nassarius nitidus (Jeffreys, 1867) [= Hinia reticulata (Linné, 1758) ] - Recently several independent lines of evidence indicate that ' $N$. reticulatus' is really a species complex with at least two species, $N$. reticulatus and $N$. nitidus. Jeffreys himself had some misgivings in proposing them as distinct species, as he knew of no cases where they were found sympatrically. According to Jeffreys both species (or forms) are found in British waters and $N$. nitidus is restricted to estuaries and certain brackish water localities. CLEMAM recognizes both species, but their geographical distribution has not been clarified yet. Both species have been documented to occur, partly sympatrically on the coast of Spain and the southern Atlantic coast of France (Sanjuan et al. 1997).

Further north the evidence is more equivocal, but already Norman (1893) remarked that all specimens he found in various localities on the western coast of Norway was rather distinct from what he knew from the British Isles, and he named it var. norvegica. Based on the drawings of Poul Winther, who illustrated one specimen from the British Isles (Harwich), and one from inner Danish waters (Hellebæk), Fretter \& Graham (1984) postulated that a short, rather squat form was a Scandinavian form, while a more solid and larger form was the common British form. They also discussed Jeffreys' $N$. nitidus, but did not explicitly connect this to any of the two forms illustrated by Winther. Graham (1988) did not refer to a Scandinavian versus a British form, but reproduced the two drawings of Winther, naming the one from Harwich $N$. reticulatus var. nitidus, while the one 
from Hellebæk was called $N$. reticulatus. Smith \& Heppell (1991) did not mention N. nitidus in their comprehensive check-list.

Rolán \& Luque (1994) followed by Sanjuan et al. (1997) claimed the specific distinctness of N. nitidus in southern Europe, based on both morphological and allozyme evidence. Warén \& Gofas (in Hansson 1998) hypothesize that $N$. reticulatus is a southern species (according to Jeffreys 1867, Linné gave the Mediterranean as the only locality for his species), with the British Isles as its northern limit, while $N$. nitidus should be a northern species, and should thus be the name of the species found in Scandinavian waters.

An alternative scenario is that both exist more or less sympatrically in Scandinavia, with $N$. nitidus restricted to brackish water localities. This is supported by investigations from southern Europe (e.g. Sanjuan et al. 1997) in which both morphospecies exist more or less in the same general area, but are only occasionally sympatric. However, the main distribution of $N$. nitidus is supposed to be the Mediterranean, while $N$. reticulatus is from the westernmost Mediterranean and the European coasts of the Atlantic. GianuzziSavelli et al. (2003) following Rolán \& Luque, provide photographs of both forms, including details of the umbilical region and the protoconch that should help to distinguish between the two.

A third possibility is that the drawings of Poul Winther represent two distinct forms of either $N$. nitidus or $N$. reticulatus, and that the other species described by Rolán \& Luque is confined to southern Europe. My material is insufficient for distinguishing between these three alternatives and the status regarding the Scandinavian representatives of the species complex is still unclear. For the time being I regard it as most likely that a single species is found in Norwegian waters, but whether this is identical to $N$. nitidus (as proposed by Warén \& Gofas), or to $N$. reticulatus (as implied by Rolán \& Luque) is unclear. As a choice have to be made, I settle for $N$. nitidus as the name of the Norwegian form.

Material of this shallow water species is usually not found unless sheltered sandflats shallower than 10 $\mathrm{m}$ are sampled. Probably for this reason published information on its distribution along the Norwegian coast is scarce. G.O. Sars (1878) reports it to be found north to 'Ora occident. Norv.', but without further specifications. Later reported from Florø and Trondheimsfjorden, c. $62^{\circ} 30^{\prime} \mathrm{N}$ (Norman 1893). Brattegard (in Høisæter et al. 1997a) has recorded it in every sector except one, north to sector $16\left(65^{\circ}\right.$ $\left.66^{\circ} 20^{\prime} \mathrm{N}\right)$. without further documentation. Wikander $(1989,1990)$ reports 16 samples with a total of more than 200 specimens from the Skagerrak coast. In my material seven specimens from Valsfjorden, Gjesvik $\left(63^{\circ} 49^{\prime} \mathrm{N}, 2-5 \mathrm{~m}\right.$, fine sand) and Søreitervåg in Eiterfjorden ( $64^{\circ} 57^{\prime} \mathrm{N}, 1.5-0.5 \mathrm{~m}$, fine sand). All of these covered with a network of hydroids, probably Podocoryne carnea (M. Sars). Presumably the species is present also in other suitable bays and sandflats along this coastal stretch, south of Bindalsfjorden (c. $65^{\circ} 10^{\prime} \mathrm{N}$ ). In the Espegrend area I have only a few samples, most of them from the same locality (Knappen-sundet, 60 19’ N, 0.5-2.0 m) with altogether upwards of 100 specimens.

Nassarius pygmaeus (Lamarck, 1822) [= Hinia pygmaea] - According to G.O. Sars (1978), and several more recent unpublished reports, this southern species (reported from as far south as Sierra Leone in Western Africa) should be found on the southern and south-western coasts of Norway. According to G.O. Sars (1878) to be found in Oslofjorden, on the southern coast and on 'Ora occidentalis Norv.'. Wikander $(1989,1990)$ lists some 30 samples with around 100 specimens from the Norwegian Skagerrak coast. Brattegard (in Høisæter et al. 1997a) expands the distribution north to $69^{\circ} \mathrm{N}$, without further documentation. However not a single shell in my material fits the description in Fretter \& Graham (1985).

Amphissa acutecostata (Philippi, 1844) [= Anachis haliaeeti (Jeffreys, 1876] - Discussed by Bouchet \& Warén (1985) who are responsible for the name change. G.O. Sars (1878) found a single juvenile specimen from deep water in Lofoten, and later three shells from the upper slope outside Vesterålen. Later reported from Vesterålen and southwards on the outer banks on the shelf of Norway (Friele \& Grieg 1901, Bouchet \& Warén 1985). Numerous records from the North Atlantic south of the Faroes, but only three samples from the Faeroese shelf (between 200 and $400 \mathrm{~m}$ ) east of the archipelago (Schiøtte in Sneli et al. 2005). In my material only three samples and only empty shells. Two shells from the coral reef at Steinavær in Andfjorden (69 $19^{\circ}$ N, 370-285 m, coral reef and coral rubble), and one shell from Tomfjorden (66 $15.5^{\circ} \mathrm{N}, 380-300 \mathrm{~m}$, mixed bottom). Data from other investigations indicate that the species in Norway may be associated with Lophelia reefs.

Mitrella rosacea (Gould, 1840) [= Astyris rosacea] - The shell is superficially similar to Thesbia nana, but on closer inspection is easily distinguished by its larger size, lack of spiral sculpture and completely different protoconch. The whorls are also 'flatter' (less convex) in $M$. rosacea. In the two illustra- 
tions I have seen (G.O. Sars 1878, and Schiøtte \& Warén 1992), the upper whorls have some axial plications. Such plications are not obvious in my inshore material, however quite distinct in the one specimen from the slope. While listed as Mitrella in Clemam (without any justification), most authors use Astyris. Not mentioned in Bouchet \& Warén (1985) or in Graham (1988). There is some confusion in Clemam and Smith \& Heppell (1991) concerning the synonymization with Fusus holboelli Møller, 1842. Schiøtte \& Warén (1992) cleared up the confusion, as Møller described several species (no less than four actually) as holboelli, among these Fusus holboelli (= Colus holboelli), and Mangelia holboelli (= Mitrella rosacea). According to G.O. Sars (1878) the species is common at intermediate depths (around $100-200 \mathrm{~m}$ ) in northern Norway, and is found gradually deeper along the western coast as far south as Bergen. Schiøtte (in Sneli et al. 2005) lists three records from 350-600 $\mathrm{m}$ around the Faroes. In my material common from Andfjorden and the fjords immediately south of Andfjorden, mostly shallower than $30 \mathrm{~m}$ (7 samples with altogether 36 specimens). Also one specimen from each of Varangerfjorden and Korsfjorden in Sør-Varanger both shallow water (0$25 \mathrm{~m}$ ). Otherwise only a couple of shells from around $67^{\circ} \mathrm{N}$, a couple of shells from Breisunddjupet $\left(62^{\circ}\right.$ $30^{\prime} \mathrm{N}, 120-60 \mathrm{~m}$ ), and a single, apparently subfossil one from around $60^{\circ} 30^{\prime} \mathrm{N}$. In the shelf 'depression' outside Fensfjorden ( $62^{\circ} 52^{\prime}$ N, $\left.471 \mathrm{~m}\right)$ one specimen. Finally a single specimen turned up in a species rich sample from the shelf/slope 'transition' sample at 543 m just off the Norwegian Trench.

Admete contabulata Friele, 1879 - Photograph of holotype in Bouchet \& Warén (1985) who synonymized it with $A$. viridula without further discussion. This synonymization is accepted by Stokland (in Sneli et al. 2005), but $A$. contabulata is listed as valid in Clemam. Inspection of the early whorls, combined with the sculpture and the characteristic shape of the body whorl, leaves no doubt of it being a distinct species. In Friele \& Grieg (1901) it is listed from three stations from the 'Norwegian North Atlantic Expedition' from $640 \mathrm{~m}\left(66^{\circ} 41^{\prime} \mathrm{N}\right)$ and $1187 \mathrm{~m}$ $\left(69^{\circ} 46^{\prime} \mathrm{N}\right)$, and a much shallower $(267 \mathrm{~m})$ locality just south of Spitzbergen at $76^{\circ} 16^{\prime} \mathrm{N}$. In my material eight specimens from eight slope stations, six of which from the upper slope between 602 and $781 \mathrm{~m}$, and one specimen in a sample from $1009 \mathrm{~m}$. In addition a postlarva from $1338 \mathrm{~m}$ in the Faroe-Shetland channel. Seems to be restricted to negative temperatures on the slope.
Admete viridula (O. Fabricius, 1780) - Illustrated and discussed in Bouchet \& Warén (1985). This predominantly Arctic species (described from West Greenland) is fairly common in soft bottom, deep water along the whole coast, although less common in the south than in northern Norway (G.O. Sars 1878). Wikander (1989) reports only a single specimen from the Skagerrak coast (140 m south of Tromøya, $8^{\circ} 55^{\prime}$ E). In my material 150 specimens with maximal abundance in Nordland south of Bodø (55 specimens) and with diminishing frequency northwards (two in the Andfjorden area, and one in East Finnmark, although many empty shells). A couple of possible shells (morphology very similar to the neotype illustrated in Bouchet \& Warén 1985). from 543 and $602 \mathrm{~m}$ on the upper slope, but otherwise not recorded from the slope.

Admete n.sp. - Based on 30 specimens from two stations on the upper slope just north of the Norwegian Trench (both c. $62^{\circ} 29.5^{\prime} \mathrm{N}, 594-604 \mathrm{~m}$ ). This locality is in the transition zone between negative and positive temperatures, at the two occasions the measured temperature was $-0.9{ }^{\circ} \mathrm{C}$ and $+1.1^{\circ} \mathrm{C}$ respectively. Smaller and narrower than A. contabulata and $A$. viridula from the same localities, and with a very constant shell morphology.

Iphinopsis inflata (Friele, 1879) [= Admete inflata $]$ Illustrated and discussed in Bouchet \& Warén (1985). In Norwegian waters only known from two syntypes and 20 shells from the type locality at the slope at $69^{\circ} 46^{\prime}$ N, 1187 m (Friele \& Grieg 1901). In my material seven specimens from five stations on the slope, between 604 and $1112 \mathrm{~m}$, the southernmost at $62^{\circ}$ $55^{\prime} \mathrm{N}$. In adition three specimens from $1338 \mathrm{~m}$ in the Faroe-Shetland channel.

Typhlomangelia nivalis (Lovén, 1846) - Provisionally placed in the subfamily Borsoniinae within Conidae but I have not been able to get this confirmed in any published work. Reported to be found along the entire Norwegian coast (G.O. Sars 1878). In my material 42 specimens and an additional 25 shells. Not present in my material from the Andfjorden area or from East Finnmark, but otherwise not uncommon, with a distinct peak in Nordland south of Bodø (31 specimens from nine samples).

Oenopota (s.l.) spp. - This is among the most problematic of all Norwegian gastropod genera, with a high number of nominal species that merge gradually into each other. The group has been treated by Bouchet \& Warén (1980), and in an unpublished thesis by 
Stokland (1981). The two revisions are completely independent as they did not know of each other, and do not always agree. Lundberg et al. (1996) performed a preliminary cladistic analysis based on selected shell and radula characters on 23 of the 25 North Atlantic species recognised by Stokland. They concluded that 12 of the 23 species included could be assigned to the genus Propebela Iredale, 1918, four of the remaining formed a separate clade sufficiently distinct to warrant its own genus name (without such a name being proposed), and the last seven could for convenience be left in Oenopota. Bogdanov (1990, not seen) in his revision of the Russian species of the group divided the species also known from Norwegian waters into two genera, Curtitoma and Propebela (Oenopota apparently not retained). The reshuffeling of species has been partly adopted by Clemam, as three subdivisions of the genus complex, Oenopota, Propebela and Curtitoma, are listed as subgenera in that list. Considering the lack of consensus, I prefer to retain all in a single genus for the time being, a decision shared with Stokland (in Sneli et al. 2005).

As far as possible I have followed Bouchet \& Warén (1980), with particular regard to their descriptions and SEM photographs of protoconchs. By following the descriptions in Bouchet \& Warén it is fairly easy to tell apart the species from western Norway and the slope, but much harder to distinguish the various forms from shallow water in northern Norway. The most resent survey of species from the slope is probably the one of Stokland (in Sneli et al. 2005) where all material from below $100 \mathrm{~m}$ around the Faroes is listed. Species from the Norwegian literature not included here are thus probably regarded by Stokland as shallow water forms either from further south or purely Arctic species, or alternatively synonyms. Of the species below I regard $O$. tenuicostata, $O$. trevelliana, O. turricula and $O$. violacea as straightforward. The remaining I have identified on the very characteristic carinated protoconch (O. elegans); incomplete sinuous axial ribs combined with lack of distinct shoulder (O. pyramidalis); spiral sculpture consisting of dense, fine lines with a somewhat broader interval just below the 'overhanging' shoulder spiral (O. assimilis/O. nobilis/O. scalaris/O. scalaroides); coarse, reticulated sculpture with axial and spiral elements of roughly the same strength (O. exarata); glassy white, without shoulder spiral 'overhang' and somewhat irregular spiral sculpture and large protoconch $(O$. bergensis); reddish or brownish with slanting axial ribs (O. harpularia). There is large variability within each of these 'groups' and I have made no attempts to make a complete list of synonyms.
Oenopota assimilis (G.O. Sars, 1878) - According to Clemam, O. scalaris sensu Bouchet \& Warén is a misidentification of $O$. assimilis. Stokland (in Sneli et al. 2005) apparently prefer the name $O$. nobilis (Møller, 1842) for this species complex (page priority?), listing O. scalaris (Møller, 1842) as a synonym, while $O$. assimilis is not mentioned. I interpret this that in the opinion of Stokland, O. assimilis is a valid species distinct from $O$. nobilis/scalaris, but only found in shallow water in the Arctic and in northern Norway. However, I follow Clemam in using $O$. assimilis as the correct name for the species called O. scalaris by Bouchet \& Warén (1980) and which according to the latter authors is fairly common from 150 to $300 \mathrm{~m}$ in the Bergen area, as well as several places on the slope around the Norwegian Sea basin. Because of the variability of shell morphology within this species complex, I also use $O$. assimilis as a 'catch-all' for shells of the 'assimilis-nobilis-scalarisscalaroides'-group. The illustrations and description of O. scalaris in Bouchet \& Warén (1980), especially their SEM photograph of the protoconch (their Fig. 268) are the basis for my interpretation of $O$. assimilis.

In my material I have assigned a number of specimens to this 'catch-all' group. A beachworn, yellowish, c. $15 \mathrm{~mm}$ long shell from Småstraumen in Sørvaranger, near the Russian border $\left(69^{\circ} 48^{\prime} \mathrm{N}\right.$, 4-12 $\mathrm{m}$, sand and shell sand, brown algae) probably should be placed in the $O$. nobilis category. A shell from Kiby, Varanger $\left(69^{\circ} 59^{\prime}\right.$ N, 220 m, soft bottom w/Rhabdammina tubes) looks like the drawing of $O$. scalaroides in G.O. Sars (1878). A very nice specimen (c. $20 \mathrm{~mm}$ long) from Toppsundet, north-west of Harstad ( $68^{\circ} 54^{\prime} \mathrm{N}, 170-150 \mathrm{~m}$, fine sand and silt) is probably of the same type, and two shells from the same sample look much like the photographs of $O$. scalaris in Bouchet \& Warén (1980).The largest of two specimens from Lille Sjona ( $66^{\circ} 12^{\prime}$ N, 70-64 m, soft bottom) looks like Fig. 149 in Bouchet \& Warén (1980). In a sample of 13 shells and specimens from Meisfjorden north-east of Sandnessjøen (66 $66^{\circ}$ ' N, $100-80 \mathrm{~m}$, soft bottom), I found six (one plus five) belonging to $O$. assimilis. In addition two rather large, old and blackened shells (18 and $19 \mathrm{~mm}$ long) which I provisionally called $O$. nobilis. Four shells of various sizes from the middle part of Velfjorden in Nordland $\left(65^{\circ} 31.5^{\prime} \mathrm{N}, 40-35 \mathrm{~m}\right.$, shells and shell gravel) seem to belong to various types of this complex, the largest most similar to O. scalaroides. A somewhat worn shell from Midfjorden in Romsdal $\left(62^{\circ} 39^{\prime} \mathrm{N}, 220-200 \mathrm{~m}\right.$, soft bottom) is quite similar to Fig. 150 in Bouchet \& Warén (1980) of a specimen from the Bergen area. Finally six specimens from 
five samples from the slope, 497 to $804 \mathrm{~m}$ (all around $62^{\circ} 30^{\prime} \mathrm{N}$ ) are placed in this group. I have no material from south of c. $62^{\circ} 30^{\prime} \mathrm{N}$.

Oenopota bergensis (Friele, 1886) - I follow Bouchet \& Warén (1980) in regarding the big protoconch and the glassy white shell to be diagnostic characters for this species. The distribution is impossible to delimit based on literature data. Friele \& Grieg (1901) mention Bergen, the mouth of Sognefjorden, Molde and Trondheimsfjorden, Bouchet \& Warén (1980) only mention the classical localities, the Bergen area, Sognefjorden and Romsdalsfjorden, while Stokland (in Sneli et al. 2005) includes the entire coast of Norway, from the Barents Sea to the Swedish border. In my material a limited number of specimens and shells, the majority from Møre og Romsdal. A good example is a juvenile from Raunefjorden, west of Fleslandsskjær $\left(60^{\circ} 17.5^{\prime} \mathrm{N}, 80-60 \mathrm{~m}\right.$, mixed bottom). A sample of four plus three from Gjerdevika in Nordmøre ( $63^{\circ} 18^{\prime} \mathrm{N}, 120-110 \mathrm{~m}$, soft bottom) also seems to belong in this category. In a sample of 13 shells and specimens from Meisfjorden north-east of Sandnessjøen ( $66^{\circ} 03^{\prime} \mathrm{N}, 100-80 \mathrm{~m}$, soft bottom), I identified seven (three plus four) as belonging to $O$. bergensis. Apparently also well represented on the upper slope, I have 10 specimens from eight stations from 502 to $830 \mathrm{~m}\left(62^{\circ} 12^{\prime}\right.$ to $\left.63^{\circ} 10^{\prime} \mathrm{N}\right)$.

Oenopota elegans (Møller, 1842) [= Oenopota cancellata (Mighels \& Adams, 1842] - According to Stokland (in Sneli et al. 2005) to be found along the coast from 'northern Norway' and southwards. In my material 11 specimens and 10 shells that might belong here. Eight specimens from northern Norway (Saltfjorden and Aldersundet) are more like the photograph in Schiøtte \& Warén (1992) than seven shells from Møre og Romsdal. Some of the best preserved of these specimens have protoconchs carinated to the top, a feature not seen in any of the species with SEM photographs in Bouchet \& Warén (1980).

Oenopota exarata (Møller, 1842) - I have chosen to use this name for the type of shell illustrated by G.O. Sars (1878) as O. exarata. This has numerous dense axial ribs and spiral cords of almost the same strength. The shoulder row of crossing points is drawn out into 'spikes'. The siphonal canal is well separated from the evenly rounded basal part of the body whorl. This Arctic form is not included either in Bouchet \& Warén (1980) or in Stokland (in Sneli et al. 2005), and according to G.O. Sars (1878) it has not been found south of Hammerfest, although not uncommon in East Finnmark. In my material a dried out specimen from
Varangerfjorden $\left(69^{\circ} 58^{\prime} \mathrm{N}\right.$, c. $300 \mathrm{~m}$, soft bottom), is fitting this description exactly, but unfortunately the larval shell is eroded. Another one from outer Bugøyfjorden (69 54' N, 15-3 m, Lithothamnion and red algae, shells of Modiolus) is somewhat less 'typical'. Specimens from three samples from the inner parts of Varangerfjorden (from 69 59' to $70^{\circ} 04^{\prime} \mathrm{N}$, deep water) are of somewhat greater variability, and unfortunately mostly with eroded top whorls.

Oenopota harpularia (Couthouy, 1839) - I have chosen this name for a small number of shells from northern Norway that at first glance seemed to fit the description of O. turricula. According to Stokland (1981) (not treated in Bouchet \& Warén 1980), O. harpularia should be most easily distinguished on its colour (reddish to brownish), but this may be rather bleached on long dead shells. Another distinguishing character is the axial ribs, which are supposed to be straight in $O$. turricula but slightly slanting in O. harpularia, which may be hard to verify. My own observations indicate that the 'valleys' between the ribs are wider and with more gradually slanting walls than in the steeper walled $O$. turricula. The shell shape is also slightly different, $O$. harpularia being shorter and wider at the same number of whorls. The protoconch has many features in common with that of $O$. turricula, but it is flatter, and with two very dominating spiral keels starting almost at the very top of the nucleus. After the first $1 / 3$ to $1 / 2$ turn, six gradually increasing spiral lirae appear, of which no. two is defining the upper edge of the whorl, and this plus no. four soon become dominating and is easily followed as strong keels in the rest of the larval shell. If my interpretations is correct, the larval shell is the most reliable character (unless it is eroded away as is far too often the case). The distribution is mainly Arctic, but according to Friele \& Grieg (1901) it occurs south to Kristiansund ( $\left.63^{\circ} 10^{\prime} \mathrm{N}\right)$. In my material the most 'typical' is a shell from outer Andfjorden $\left(69^{\circ} 17^{\prime} \mathrm{N}, 80-65 \mathrm{~m}\right.$, coarse shell gravel), another one, slightly more worn, from the northern shores of Varangerfjorden ( $70^{\circ} 07^{\prime} \mathrm{N}, 6 \mathrm{~m}$, mostly Laminaria). A batch of six rather worn shells from a station just east of this $\left(70^{\circ} 06^{\prime} \mathrm{N}, 10-3 \mathrm{~m}\right.$, lots of Laminaria) might also belong to this species. One or both of two shells from the sound between Leirfjorden and Vefsnfjorden $\left(66^{\circ} \mathrm{N}, 140-120 \mathrm{~m}\right.$, gravel and coarse sand) determined to $O$. turricula may also belong to this species.

Oenopota impressa (Mørch, 1869) - According to Stokland (in Sneli et al. 2005) found south to Lofoten. Not treated in Bouchet \& Warén (1980). I have placed 10 
specimens from East Finnmark in this category.

Oenopota nobilis (sensu Stokland, 1981) - Because of the confusion within the complex $O$. assimilis/O. nobilis/O. scalaris/O. scalaroides, all shells most likely belonging to this complex have been discussed under $O$. assimilis.

*Oenopota ovalis (Friele, 1877) - This characteristic species was described from material taken by the Norwegian North Atlantic Expedition from 2222 $\mathrm{m}$ on the deeper slope north of the Faroe shelf, due west of Smøla (63 22' N, $05^{\circ} 29^{\prime}$ W). Bouchet \& Warén $(1979,1980)$ list a number of records from the Norwegian Sea abyssal Basin, where it has been taken up to $1400 \mathrm{~m}$ on the eastern slope (Grieg 1915), and $932 \mathrm{~m}$ on the Kolbeinsey Ridge north of Iceland (Bouchet \& Warén 1979). Probably also to be found on the Norwegian slope above $1200 \mathrm{~m}$. Common in the NTNU material (det. Stokland) from the bathyal an abyssal Norwegian Sea. In my material 69 specimens from nine samples, all from deeper than 2000 $\mathrm{m}$.

Oenopota pyramidalis (Strøm, 1768) - Not mentioned in either Bouchet \& Warén (1980) or Stokland (in Sneli et al. 2005). Accepted by Clemam however, and according to Friele \& Grieg (1901) to be found south to Lofoten. In addition to four specimens from the above mentioned locality on the northern shores of Varangerfjorden ( $70^{\circ} 06^{\prime} \mathrm{N}, 10-3 \mathrm{~m}$, lots of Laminaria), a well preserved specimen from Nesna $\left(66^{\circ} 15^{\prime} \mathrm{N}\right)$, ca. $13 \mathrm{~mm}$ long. This does not agree completely with $O$. pyramidalis, and could also be a specimen of $O$. nobilis (or $O$. scalaris).

Oenopota tenuicostata (G.O. Sars, 1878) $[=$ O. decussata (Couthouy, 1839)] - One of the three most common species of the genus in western Norway. According to Stokland (in Sneli et al. 2005) found along the Norwegian coast south to Bergen. In my material a single specimen from Korsfjorden $\left(60^{\circ} 08^{\prime} \mathrm{N}, 430\right.$ $400 \mathrm{~m}$, gravel and clay). Seven other shells from the Espegrend area were empty, and mostly eroded. Further north evenly distributed north to Bodø, with a peak of 28 specimens in Nordland south of Bodø. A single shell from Grovfjord (68 42’ N, 235-200 $\mathrm{m}$, soft bottom) was the only one north of Lofoten. In my material it is also the by far most common Oenopota on the slope, with 40 specimens in nine samples on the upper slope, from 497 to $1030 \mathrm{~m}$. In addition I have four specimens from $1338 \mathrm{~m}$ in the Faroe-Shetland channel.
Oenopota trevelliana (Turton, 1834) - One of the three most common species in western Norway. Found along the whole coast and into Kattegat according to Stokland (in Sneli et al. 2005). Wikander (1990) reports two specimens from a sample from $40 \mathrm{~m}$ just south of Farsund, 58 $06^{\prime} \mathrm{N}, 6^{\circ} 47^{\prime} \mathrm{E}$, as the only Oenopota in his lists. In my material three specimens from Ypsesundet in Herdlafjorden $\left(60^{\circ} 33^{\prime} \mathrm{N}\right.$, 59-53 m, silt and clay), and several scattered ones from the Espegrend area. Three fine specimens from Aldersundet ( $66^{\circ} 27^{\prime} \mathrm{N}, 110-100 \mathrm{~m}$, foraminiferans). Otherwise evenly distributed northwards, including two specimens from East Finnmark.

Oenopota turricula (Montagu, 1803) - All earlier records of this species from Norwegian waters are unreliable. I regard those found by Warén (in Bouchet \& Warén 1980 ) in the Bergen area to represent the (approximate) northern limit for this species. In my material a shell from Breisunddjupet $\left(62^{\circ} 28^{\prime} \mathrm{N}, 120-60 \mathrm{~m}\right.$, shell sand) might be this species. The protoconch of this shell is exactly like the SEM photograph (Fig. 267 ) in Bouchet \& Warén (1980). My least controversial shell is from east of Geitingen between Alvøy and the island One in Øygarden $\left(60^{\circ} 34^{\circ} \mathrm{N}, 105-80\right.$ $\mathrm{m}$, fine sand and mud). Later I found two shells of typical habitus, in the sound between Leirfjorden and Vefsnfjorden $\left(66^{\circ} \mathrm{N}, 140-120 \mathrm{~m}\right.$, gravel and coarse sand) which probably is a new northern distributional limit. Three specimens from Ypsesundet ca. $55 \mathrm{~m}$, and an early (1951) one from the Espegrend area, are the only ones caught live.

Oenopota violacea (Mighels \& Adams, 1842) - See Bouchet \& Warén (1980) and Stokland (in Sneli et al. 2005). The third of the three most common species on the west coast, and one of six species distributed along the whole Norwegian coast. In my material 14 specimens, the majority found between $63^{\circ}$ and $67^{\circ}$ $\mathrm{N}$, and an additional 70 shells. A single specimen from the Espegrend area, so based on my material alone $O$. turricula is more common on this part of the coast than $O$. violacea. Also found on the upper slope. In my material 14 specimens from four samples, from 543 to $708 \mathrm{~m}$. Also a single specimen from $1220 \mathrm{~m}$ in the Faroe-Shetland channel, and one from $879 \mathrm{~m}$ on the ridge south of Jan Mayen $\left(69^{\circ} 01^{\prime} \mathrm{N}\right)$.

Bela spp. - (See below under Mangelia spp. (s.l.))

Bela brachystoma (Philippi, 1844) [= Mangelia brachystoma] - Previously reported from western Norway by G.O. Sars (1878). Brattegard (in Høisæter et al. 1997a) reports it from his sectors 1, 4-6 and 9. The 
ones from the Skagerrak coast (sectors 4-6) may be due to Wikander $(1989,1990)$ who records 24 specimens from 10 stations in his survey. I have no specimens from Norwegian waters as defined here, but four specimens were found in the North Sea, on the western slope of the Norwegian Trench, 84 and $115 \mathrm{~m}$ (coll. and leg. Per Johannessen).

*Bela costulata (Risso, 1826) [= Mangelia costulata] - Not with certainty recorded from Norwegian waters. G.O. Sars (1878) records Mangelia striolata (Philippi) ( $M$. striolata (Risso, 1826) listed as a synonym of B. costulata in CLEMAM) from the west coast, south coast and Oslofjorden. Whether this species is synonymous with $B$. costulata (Risso) is hard to tell. Jeffreys (1867) cites Danielssen as having found it near Kristiansund $\left(63^{\circ} 10^{\prime} \mathrm{N}\right)$, and also that Lilljeborg found it in Norway. Not reported in any newer fauna lists from Norway, and Warén (in Hansson 1998) stated that it is not found in Scandinavian waters. In the British Isles it is found on the western coasts as far north as the Hebrides (Graham 1988). Not in my material.

Bela nebula (Montagu, 1803) [= Mangelia nebula Reported by G.O. Sars (1878) from the west coast. Two specimens found by Norman (1879) in Korsfjorden (c. $\left.60^{\circ} 10^{\prime} \mathrm{N}\right)$. Not uncommon in the Skagerrak area (Wikander 1989, 1990; and in an unpublished list by K.M. Olsen 1993, identified by Warén). Not in my material.

Bela powisiana (Dautzenberg, 1887) - First Norwegian record from outside Tromøy in Aust-Agder (58 26' N, 12 m, sand) in Wikander (1990). Later reported from Skagerrak and Oslofjorden in an unpublished list by K.M. Olsen 1993 (identified by Warén and C. Schander). Also found at $150 \mathrm{~m}$ on the Faroe Bank (Warén in Sneli et al. 2005). Not in my material.

Mangelia spp. (s.l.) - Clemam divides the six species reported from Norwegian waters of this, predominantly Lusitanian or Mediterranean, group between the genera Bela J.E. Gray, 1847 and Mangelia Risso, 1826. Both the systematics and the nomenclature of the members of the group is problematical, and the experts do not at all agree on the classification. As I have decided to follow CLEMAM, I use their classification below, and thus assign $M$. brachystoma, M. costulata, M. nebula and M. powisiana to Bela, while $M$. attenuata and $M$. coarctata are retained in Mangelia. A number of these species have recently been reported from the Skagerrak area, but few of these have been found alive in the Bergen area or fur- ther north recently, although reported by G.O. Sars (1878) to be living north to c. $61^{\circ} \mathrm{N}$, (or 'Ora occident. Norv.', see G.O. Sars 1878; Høisæter 1986).

Mangelia attenuata (Montagu, 1803) - Previously reported from western Norway by G.O. Sars (1878). Brattegard (in Høisæter et al. 1997a) reports it from his sectors 1, 4, 6 and 9. The reports from sector four (Skagerrak) are probably based on Wikander $(1989,1990)$ who reports four samples with a single specimen in each from the Skagerrak coast. According to Graham (1988), the main distinguishing character for $M$. attenuata is the absence of the deep and narrow anal sinus a little away from the wall of the last whorl. This character is hard to verify in juveniles and worn specimens, and the distinction from the variable $M$. coarctata may be hard to establish. In my material mostly old and worn shells, and the identification is therefore not very reliable. One fairly convincing example is a well-preserved $12.8 \mathrm{~mm}$ long shell from west of Bukken (in Raunefjorden, 60 $14^{\prime} \mathrm{N}$, $22 \mathrm{~m}$, shell gravel, stones and shells of Arctica, coll. and leg. Anders Warén). This might belong to $M$. attenuata, it being narrow, with anal sinus close to the wall of the penultimate whorl, and with remnants of colour pattern consisting of alternate narrow and numerous brown and light yellow spiral bands, and finally a length exceeding the maximum listed for M. coarctata in Graham (1988). It does possess, however, the occasional larger, more distinct spiral ridges on the first three teleoconch whorls which (according to Graham) should be characteristic for $M$. coarctata. Also reported by Johannessen (Vassenden et al. 2007) from Ølsfjorden in Sunnhordland (c. 59 3 $36^{\prime} \mathrm{N}$, three specimens from 50, 25 and $23 \mathrm{~m}$, soft bottom). Another intriguing find is an old but fairly well preserved shell, $8.5 \mathrm{~mm}$ long, from Vefsn-fjorden $\left(66^{\circ}\right.$ N, 140-120 m, gravel and coarse sand). Except for the size this is very similar to the shell from Bukken. How recent this shell is, is hard to tell, but in any case it would be an appreciable northern extension of its distribution in Norway.

Mangelia coarctata (Forbes, 1840) - Previously reported from western Norway by G.O. Sars (1878). Brattegard (in Høisæter et al. 1997a) reports it from his sectors 1, 3-6 and 9. Wikander $(1989,1990)$ reports 11 samples with a total of 14 specimens from the Skagerrak coast. In my material a single specimen c. $11 \mathrm{~mm}$ long, from Mefjordbåen, Hjeltefjorden ( $60^{\circ} 36^{\prime}$ N, 30-40 $\mathrm{m}$, fine shell sand). According to the description in Graham (1988) M. coarctata is the only reasonable candidate for this specimen. Two records of shells from Foldafjorden $\left(64^{\circ} 40^{\prime} \mathrm{N}\right)$ and Namsenfjorden 
$\left(64^{\circ} 26^{\prime} \mathrm{N}\right)$ are based on old and worn fragments. The eight other shells I have listed as $M$. coarctata are all so old and worn that they might as well be shells of M. attenuata. In addition to my Norwegian material, I have two specimens (6.5 and $5.9 \mathrm{~mm}$ long) from 300 $\mathrm{m}$ at a station south of the Faroes (Lousy Bank, $60^{\circ}$ $25^{\prime} \mathrm{N}$ ). Colour of the largest of the two is yellowish white, without any coloured bands or other pigment, while the other had some light brown spots on the body whorl that might be remnants of a broader brown spiral band just below the suture. These two are the only specimens in my material looking like available illustrations of $M$. coarctata from the Mediterranean. The specimen from Mefjordbån is darkish yellow, with a broad brown band below the suture on earlier whorls and brown and light coloured axial costae on the body whorl. They are rather long and narrow for being 'typical' $M$. coarctata though. As the two specimens assigned to $M$. attenuata above also have some features better fitting the description of $M$. coarctata, the status of this group in Norwegian waters is rather confusing.

Raphitoma spp. - The traditional subdivision of this genus into $R$. linearis, $R$. purpurea, $R$. echinata (= R. asperrima) and R. leufroyi (e.g. Graham 1988), has turned out to be untenable, and the group is now under revision. The following six provisional 'species' are based on my material only. As the species in this genus are unusually variable as far as shell characters go, and sometimes shell features overlap considerably between 'species', only fairly 'typical' specimens are safely identified. As colours fade quickly in empty shells the identification of old and worn shells is a hazardous business at best.

Raphitoma aequalis (Jeffreys, 1867) [= Philbertia linearis (Montagu, 1803) in part] - This species, first described by Jeffreys in 1867 as a variety of $R$. linearis, has not previously been distinguished from the latter species in the literature from Norway. It proved to be the most abundant and widespread of the six 'species'. It is found all along the coast to at least $69^{\circ} \mathrm{N}$, and it is most likely to be the ' $R$. linearis' reported from Norway north to $70^{\circ} 30^{\prime} \mathrm{N}$ by G.O. Sars (1878) and from Trondheimsfjorden and Lofoten by Norman $(1893,1902)$. In the Wikander material from Nordland I found 103 specimens in 14 samples. In my own material it is equally well represented in the series from the Andfjorden area as in the series from Nordland, Nord-Trøndelag and Møre og Romsdal. Forty of a total of 72 specimens are from the Espegrend series though. In the Espegrend samples this species is frequently found together with $R$. linearis and $R$. concinna in samples from less than around $30 \mathrm{~m}$. In the Wikander material from Skagerrak, around 100 specimens from 16 samples are best referred to this species.

Raphitoma concinna (Scacchi, 1836) [= Philbertia leufroyi (Michaud, 1828)] - The naming of this species is not straightforward. $R$. leufroyi has been the name traditionally used for the north-European species while R. boothi (Smith, 1839) has been used more rarely, while $R$. concinna has so far not been used for the north-European species in any printed work. $R$. leufroyi was described from Recent material from the Mediterranean coast of France, $R$. concinna was based on material from the coast of southwestern Italy, and $R$. boothi was described from Scotland. Warén (pers. commn and in Hansson 1998, 2003) has compared Nordic specimens with specimens of $R$. concinna from the Mediterranean, and is unable to find any conchological differences. Recently CLEMAM has included $R$. boothi as a synonym of $R$. concinna and it may thus be inferred that CLEMAM recognizes $R$. concinna as the valid name for our species. In order to be consistent I thus accept $R$. concinna as the name of our species.

Jeffreys (1867) cites M. Sars as the source for a record from Bergen. Subsequently reported by Friele (1874) as rare from the Bergen area, by G.O. Sars (1878) from the western and southern coast including Oslofjorden, by Norman (1879) from Bukkasundet in Raunefjorden (around 60 $15^{\circ} \mathrm{N}$ ). Later reports include Norman (1893) who found a juvenile near Trondheim (around $63^{\circ} 25^{\prime} \mathrm{N}$ ), and a single specimen from Stjørdalsfjorden further east in Trondheimsfjorden (Sneli \& Gulliksen 2006). Wikander $(1989,1990)$ reports the species from three samples from the Skagerrak coast, and I found an additional seven specimens in two of the Wikander samples from Skagerrak. Not found by Sneli (1974, 1979) in his samples from Møre og Romsdal or in Sognefjorden. I have a rich material from the Espegrend area, some 55 specimens from 25 samples, but none from farther north, and the species appears to be rather rare north of Bergen. This shallow water species is frequently found together with $R$. aequalis and $R$. linearis in samples from around Espegrend.

Raphitoma echinata (Brocchi, 1814) [= Philbertia asperrima (Brown, 1827)] - Previously reported from narrow sounds north of Bergen $\left(60^{\circ} 35^{\prime}\right.$ and $\left.60^{\circ} 40^{\prime} \mathrm{N}\right)$ by Friele (1874), and from western Norway by G.O. Sars (1878) (may be the same records). Not found by Norman (1879). To my knowledge, no further published records from Norwegian waters. In my mate- 
rial one somewhat damaged shell from Andfjorden, east side near north point of Andøya $\left(69^{\circ} 17^{\prime} \mathrm{N}\right.$, 60-80 m, coarse shell gravel with fairly large shell fragments), a fragment of a shell from Stokken in Nord-Trøndelag $\left(\begin{array}{lll}64^{\circ} & 03.5^{\prime} & \mathrm{N}\end{array}\right)$ and one juvenile (4.95 mm) from Kinnarosen $\left(60^{\circ} 14^{\prime} \mathrm{N}, 5^{\circ} 14^{\prime} \mathrm{E}\right.$, 117-97 m, mixed, mostly soft, bottom. Collected in 1951). Recently (4 September 2007) a specimen was dredged from Liholmsrennen, Raunefjorden $\left(60^{\circ} 17^{\prime}\right.$ N, 60-80 m, Modiolula phaseolina shells and mud). Finally, a very similar specimen from the Wikander material from Nordland (northern point of Store Hjartøya, $67^{\circ} 18.5^{\prime} \mathrm{N}, 70 \mathrm{~m}$, pebbles and shells of Arctica, coarse shell gravel). These two, the only completely fresh specimens in my collection, may be the 'real' $R$. echinata, but the confusion around the taxonomy of this species is great and I do not exclude that it might be an undescribed species. Apparently this species lives deeper than the three common shallow water species in our fauna.

Raphitoma linearis (Montagu, 1803) [= Philbertia linearis in part] - The species traditionally called $R$. linearis in the north European fauna has recently been split into $R$. linearis and $R$. aequalis. Previously reported from Oslofjorden by Jeffreys (1870), but whether this refers to $R$. linearis s.str., or to $R$. aequalis is unclear. The same goes for the records in Friele (1874) and Norman (1879) from the area around Bergen, but as both these species are found in my material from the same area, their records most likely refer to a mixture of the two. G.O. Sars (1878) reported it from the entire coast north to $70^{\circ} 30^{\prime} \mathrm{N}$. Most of his records from north of $61^{\circ} \mathrm{N}$ are probably based on $R$. aequalis, however. I have found $R$. linearis only in a few localities in the Espegrend area, although in fairly high numbers in samples from these localities ( 82 specimens in 21 samples). On this part of the coast frequently found together with $R$. aequalis and $R$. concinna. A few scattered specimens in the Wikander material from both Skagerrak and Nordland seem to best fit into this category.

Raphitoma purpurea (Montagu, 1803) [= Philbertia purpurea] - Reported by Friele (1874), G.O. Sars (1878) and Norman (1879) from various localities around Bergen. Friele reported it as rare from just north of Bergen harbour $\left(60^{\circ} 25^{\prime} \mathrm{N}\right)$, while Norman had a shell from Raunefjorden, around $60^{\circ} 16^{\prime} \mathrm{N}$. In the case of G.O. Sars only in his synoptic tables, as found in 'Ora occident. Norv.' (may be based on Friele's record). According to Hansson (2003) in Norway distributed from the Bergen area north to Lofoten. In the Wikander material from Skagerrak I found two shells that might belong here. In my own material four shells, one very well conserved, from a station in the sound NE of Vikna in Nord Trøndelag ( $64^{\circ} 55^{\prime} \mathrm{N}$, 175-20 m, shell sand). Unfortunately all are rather old and lack most of the protoconch. Obviously a rare species in Norwegian waters, and not reported alive since the 1870's.

Raphitoma n. sp. - Three fairly small specimens, 7.3, 6.7 and $4.5 \mathrm{~mm}$ long respectively, probably belong to an undescribed species. The samples are from somewhat deeper water $(95-70 \mathrm{~m})$ than the other species (except $R$. echinata) from the Espegrend area. A single, somewhat smaller one $(4.3 \mathrm{~mm})$ from the Wikander material from Nordland (Lille Hjartøya, $67^{\circ} 17^{\prime}$ N, 70-60 m, Modiolula phaseolina shell sand and stones) might be the same species. The shells are pure white (or slightly yellowish) and with unusually convex whorls and corresponding deep sutures.

Nepotilla amoena (G.O. Sars, 1878) - Described from three specimens from Hasvik in western Finnmark (c. $70^{\circ} 29^{\prime} \mathrm{N}, 110-180 \mathrm{~m}$ ), since reported from several localities on the upper slope north of $69^{\circ} 40^{\prime} \mathrm{N}$, near Tromsø (Schneider 1886), and from Porsangerfjorden and Tanafjorden (Friele \& Grieg 1901). In my material a single, worn shell from the upper slope in Bleiksdjupet, west northwest of Andenes (69 $25^{\circ} \mathrm{N}$, 700-200 m, silty sand with small stones and clay).

Teretia teres (Reeve, 1844) [= Teretia teres (Forbes in Reeve, 1844)] - CLEMAM does not agree with Bouchet \& Warén (1980) (who cite Forbes as the author) in regard to the authorship of this species. Previously reported from Norway north to $70^{\circ} 30^{\prime} \mathrm{N}$ by G.O. Sars (1878). Wikander (1990) reports five samples with a total of 10 specimens from the Skagerrak coast. In the Wikander material, an additional seven specimens and seven shells from Skagerrak, but none from Nordland. In my material 23 specimens and an additional 25 shells, of which six specimens and 15 shells from nine stations in Møre og Romsdal. I have no material from north of $68^{\circ} \mathrm{N}$, and only eight samples with a total of three specimens from Nordland south of Bodø and Nord-Trøndelag.

Pleurotomella packardi Verrill, 1872 - Common in the bathyal of the North Atlantic and apparently in the abyssal of the Norwegian Sea (Bouchet \& Warén 1979, 1980). From the slope in Norwegian waters a single specimen found at $730 \mathrm{~m}$ outside Storegga by G.O. Sars, who also found empty shells outside Senja $\left(69^{\circ} 46^{\prime} \mathrm{N}\right)$ at $1187 \mathrm{~m}$. In my material a single juvenile from $701 \mathrm{~m}$ at $62^{\circ} 32^{\prime} \mathrm{N}$, another from $1009 \mathrm{~m}$ at 
$62^{\circ} 48^{\prime} \mathrm{N}$, and also two from below $2500 \mathrm{~m}$.

Thesbia nana (Lovén, 1846) - Previously reported from the entire coast except East Finnmark by G.O. Sars (1878). In my material 28 specimens (of which one from East Finnmark and 15 from the Andfjorden area) and an additional 182 shells.

Taranis borealis Bouchet \& Warén, 1980 - Previously known from Norway from 24 specimens and shells from the Bergen area, 150-680 m (Bouchet \& Warén 1980). I have a number of specimens presumably belonging to this species partly in the same samples as the more common T. moerchi. According to the original description, the most obvious diagnostic characters should be the small (distinctly smaller than the one of T. moerchi), golden brown (the colour is just as likely to be 'offwhite' though) protoconch densely covered with granulated spirals (similar spirals also found on the protoconch of T. moerchi), a somewhat squat appearance with a short siphonal canal, and fewer and more distinctive axial and spiral sculpture elements than in T. moerchi (T. moerchi is stated to be extremely variable in this respect, however). Sometimes more slender shells have most of the other characters listed here. Also stated to have only three strong spiral lines below the peripheral keel on the body whorl, and lacking spiral sculpture on the siphonal canal. In my material one specimen from the deepest part of Korsfjorden (c. $60^{\circ} 11^{\prime}$ N, 680 m) and a shell from the same locality. The majority, 12 of 15 , of my specimens, are from the deeper parts of Fensfjorden. In addition several specimens from, Molde-/Mifjorden ( $62^{\circ} 40^{\prime} \mathrm{N}, 200-450 \mathrm{~m}$, soft bottom). Further, a sample from Voldafjorden $\left(62^{\circ} 10^{\prime} \mathrm{N}\right.$, 650-690 m, soft bottom) contained several specimens that best fit $T$. borealis, although not all the characters above are present. A single shell from Lille Sjona, near Nesna ( $66^{\circ} 12^{\prime} \mathrm{N}, 70-64 \mathrm{~m}$, soft bottom) as well as five shells from Tomfjorden ( $66^{\circ} 15.5^{\prime} \mathrm{N}, 380-300$ $\mathrm{m}$, mixed bottom) also in all probability belong to this species. This latter might thus represent the northern distributional limit for the species.

Taranis moerchi (Malm, 1863) - Previously reported from the whole coast, from Oslofjorden to Vadsø (G.O. Sars 1878). Wikander (1990) reports only two samples with three specimens from the Skagerrak coast. The species is reported to be very variable (Bouchet \& Warén 1980), and G.O. Sars (1878) mentioned that he had found two unusually large specimens near Vadsø. In several samples from northern Norway (between $67^{\circ} 15^{\prime} \mathrm{N}$ and $65^{\circ} \mathrm{N}$ ) a more slender form with rather coarse sculpture is found alongside 'typi- cal' T. moerchi. One shell from Lille Sjona ( $66^{\circ} 12^{\prime}$ $\mathrm{N}, 70-64 \mathrm{~m}$, soft bottom) and at least three specimens from Aldersundet north of Aldra ( $66^{\circ} 27^{\prime} \mathrm{N}, 110-100$ $\mathrm{m}$, foraminiferous bottom substrate) may belong to this category. The slender specimens also have some prominent black spots visible through the shell close to the front of the head region, spots that are not seen on 'typical' T. moerchi or T. borealis. The peripheral keel is usually very prominent in T. moerchi, and the keel on the slender form is far less dominating. The slender form is thin shelled, with a microsculpture of countless minute, densely spaced pustules covering the spaces between spiral ribs. These ribs number at least nine on the body whorl, and extends down to the end of the siphonal canal. The axial sculpture is comparatively weak, and less dense than in 'typical' T. moerchi. Unfortunately the upper part of the spire is somewhat eroded in the available specimens so that details of the protoconch cannot be trusted. Some juveniles from Indre Visten $\left(65^{\circ} 38^{\prime} \mathrm{N}, 180 \mathrm{~m}\right.$, soft bottom) are aberrant in that they have an even more dominating spiral sculpture, with the strong spiral keel starting immediately after the larval shell, and with very dense and weak slanting axial lines.

In my material 196 specimens and an additional 130 shells, more or less evenly distributed north to Bodø, but only occasionally found further north. A single specimen was found in East Finnmark, inner Varangerfjorden southwest of Vestre Jakobselv $\left(70^{\circ}\right.$ 04' N, $174 \mathrm{~m}$, fine sand), and also a single specimen in the Andfjorden area, in the rich sample from Gratangen ( $68^{\circ} 44^{\prime} \mathrm{N}, 90-80 \mathrm{~m}$, fine shell sand with many Modiolula shells). The species is mostly a typical soft bottom inhabitant, found, sometimes abundantly, on the bottoms of the deep fjords at least down to $680 \mathrm{~m}$, but occasionally also in rather shallow water with coarser substrate, as e.g. in Vevelstadsundet $\left(65^{\circ} 42.5^{\prime} \mathrm{N}, 65-45 \mathrm{~m}\right.$, sand and shell gravel) where some very large specimens were found.

Spirotropis modiolus (de Cristofori \& Jan, 1832) [= Spirotropis monterosatoi (Locard, 1897)] - This species has been subjected to several name changes over the years. Warén (1975) replaced (because of preoccupation) the well known Spirotropis carinata (Bivona, 1838) used by G.O. Sars (1878), with Spirotropis sarsi Warén, 1975. Bouchet \& Warén (1980) decided that Spirotropis monterosatoi (Locard, 1897), described from bathyal depths outside the Atlantic coast of Morocco, had priority. Sabelli et al. (1992) argued that the fossil described by de Cristofori \& Jan is the same species as the Recent $S$. monterosatoi, and thus $S$. modiolus should be used. Warén apparently 
disagrees, and suggests an alternative name for the species, S. confusa G. Seguenza, 1880 (Warén in Hansson 1998). Clemam lists both $S$. modiolus (with S. confusa and $S$. sarsi as synonyms) and $S$. monterosatoi, indicating that they regard the southern, bathyal form as distinct from the shallower living, more northern $S$. sarsi/confusa/modiolus, which again should be conspecific with the Miocene fossil described by de Cristofori \& Jan. G.O. Sars (1878) reports it from all along the coast from around $59^{\circ} \mathrm{N}$ to Vardø in East Finnmark at $70^{\circ} 22^{\prime}$ N. He did not find it on the south coast or in Oslofjorden though. In my material 20 specimens and an additional 23 shells, the northernmost at $67^{\circ} 10^{\prime} \mathrm{N}$, but further south rather evenly if not very abundantly distributed in all the sectors.

*Haedropleura septangularis (Montagu, 1803) - Jeffreys (1867) reported it from the Bergen area on the authority of M. Sars, but G.O. Sars (1878:374) excluded it from his synoptic tables as an obvious misidentification. A record in Ankel (1936) was apparently copied from Jeffreys (1867). Not in my material and most likely not a member of the Norwegian fauna.

Turritellopsis stimpsoni Dall, 1919 [= Turritellopsis acicula (Stimpson, 1851)] - Transferred to Mathildidae, illustrated and discussed in Warén (1996a). In Norway only known from shallow water $(10-30 \mathrm{~m})$ at a few localities near Vadsø in Varangerfjorden, East Finnmark (G.O. Sars 1878, Norman 1902, and Warén 1996a). According to G.O. Sars (1878) also found at Magerøya $\left(\right.$ c. $\left.71^{\circ} \mathrm{N}\right)$ by Verkrüzen. Not in my material.

Rissoella diaphana (Alder, 1848) - Previously reported from algae in very shallow water in Korsfjorden (c. $60^{\circ} 08^{\prime} \mathrm{N}$ ) by Friele (1876). Apparently never reported later. In my material four specimens from the littoral at Svartholmane in the outer part of Fanafjorden $\left(60^{\circ} 15^{\prime} \mathrm{N}\right)$, presumably collected from coralline algae.

Rissoella globularis (Forbes \& Hanley, 1853) [= Rissoella globularis (Jeffreys, 1852)] - Previously reported from Tromsø harbour $69^{\circ} 30^{\prime} \mathrm{N}$, and the archipelago just outside Sognefjorden $\left(61^{\circ} \mathrm{N}\right)$ by G.O. Sars (1878). In my material altogether 122 specimens from three shallow-water stations around $64^{\circ} 30^{\prime} \mathrm{N}$, and a single large sample of specimens from 'Nordhellningsneset' Kvalsund in Troms $\left(69^{\circ} 49^{\prime} \mathrm{N}\right)$ collected 06.051966.

*Rissoella opalina (Jeffreys, 1848) - Apparently the only record from Norwegian waters is the one of Friele
(1874) (several empty shells from Kvarven, $35 \mathrm{~m}$ ). G.O. Sars (1878:374) excluded it from his synoptic tables as an obvious misidentification. Otherwise reported by Sneli (in Sneli et al. 2005) from south and soutwest of the Faroes, at 600-640 m depth. Not in my material and most likely not a member of the Norwegian fauna.

Omalogyra atomus (Philippi, 1841) [= Omalogyra atomus (Philippi, 1844)] - Previously reported, on the authority of M. Sars and Verkrüzen, from Oslofjorden, the west coast and Vadsø in Varangerfjorden (G.O. Sars 1878). Wikander (1990) reports a single specimen in a sample from $15 \mathrm{~m}$ outside Grimstad $\left(58^{\circ} 19^{\prime} \mathrm{N}\right)$. In my material only a handful of specimens from the Espegrend area, 14 specimens from shallow-water stations around $64^{\circ} 30^{\prime} \mathrm{N}$, and a single shell from Breisunddjupet $\left(62^{\circ} 28^{\prime} \mathrm{N}\right)$. Probably overlooked because of its minute size, but in any way far less common than Ammonicera rota in the Espegrend area.

Ammonicera rota (Forbes \& Hanley, 1850) - First reported from Norway in Høisæter (1968). It is one of the smallest species in the Norwegian fauna and also the locally most numerous one. Altogether some 13000 specimens picked out in my material from the locality Hillersholmen in Raunefjorden $\left(60^{\circ} 18^{\prime} \mathrm{N}, 5-10\right.$ $\mathrm{m})$. Further north, a single specimen (together with 10 Omalogyra and 42 Rissoella globularis) from Fløan, near Stamnes in Nord-Trøndelag (64 $\left.30^{\prime} \mathrm{N}\right)$. Like Omalogyra, probably largely overlooked because of its small size.

Xylodiscula planata Høisæter \& Johannessen, 2001 Reported by Høisæter \& Johannessen (2001) from the outer parts of Sognefjorden and from outside Sotra and outer Hardangerfjord, always in moderate depths, 34-54 $\mathrm{m}$ and in the immediate vicinity of salmon farms. No further material has appeared since the description.

PyramidellidaE - With the exception of the genera Odostomia (s.l.) and Turbonilla (s.l.) the Norwegian members of this group have been revised by Warén (1989, 1991). His interpretations have been largely followed, but the family will be treated more indepth in a future revision. Among other things the generic division is highly artificial and will have to be changed. In this review, all generic names follow Clemam, although I disagree in a number of cases.

*Aartsenia candida (Møller, 1842) - The only Norwegian record of this Arctic species are two shells from 
Karlsøy, Troms county (70 N, 9-27 m) (Warén 1991). The record is obviously from the same sample as the one mentioned for Buccinum scalariforme Møller, 1842 above. As all other records of the species are from Greenland, Spitsbergen (incl. Kong Karls Land) and the Kara Sea, the record might be due to a mix-up of place names. The presence of this species in Norwegian waters needs verification. Not in my material.

*Chrysallida bjoernssoni Warén, 1991 - The 20 shells on which the description was based are from 200 $m$ in southeastern Iceland. The only known additional material is two shells from $156 \mathrm{~m}$ in eastern Greenland. In my material three samples from the Andfjorden area, eight and two fairly well preserved shells from the two Lophelia reef samples, and seven from the sample from Bleiksdjupet northwest of Andøya, (69 $25^{\circ} \mathrm{N}, 200-700 \mathrm{~m}$, stones and clay). In addition a single shell from the Norwegian Trench, $311 \mathrm{~m}$, at $61^{\circ} 30^{\prime} \mathrm{N}$. The most decisive character is the keeled protoconch which look very similar to the one illustrated in Warén (1991). All of these four samples are from depths around or a little below $300 \mathrm{~m}$. New to Norway if this identification is correct, but not verified that it is still living here.

Chrysallida brattstroemi Warén, 1991 - This species was described from 21 specimens from a sample taken just south of Færder in the Skagerrak (58 54' N. $10^{\circ}$ 33' E, 200-220 m, mud with arenaceous foraminiferans). Warén reported in addition five specimens from the shelf outside Korsfjorden ( $60^{\circ} 08^{\prime}$ N, 250 to $380 \mathrm{~m}$ ) and a single shell from Trondheimsfjorden. Otherwise known from the Mediterranean. In my material altogether 13 specimens and an additional 16 shells. Three shells from Tomfjorden ( $66^{\circ} 12^{\prime} \mathrm{N}$, 380-300 $\mathrm{m}$, mixed bottom), one specimen and one shell from outer part of Bindalsfjorden, $\left(65^{\circ} 12^{\prime} \mathrm{N}\right.$, $12^{\circ} 10^{\prime} \mathrm{E}, 510-460 \mathrm{~m}$, soft bottom), and four samples from Risvær-fjorden $\left(65^{\circ} \mathrm{N}, 11^{\circ} 29^{\prime} \mathrm{E}, 100-200 \mathrm{~m}\right.$, shells only). Finally 12 well preserved specimens from the shelf outside Korsfjorden $\left(60^{\circ} 07^{\prime} \mathrm{N} 4^{\circ} 51^{\prime}\right.$ E, 317-315 m, silty sand with lots of foraminiferans; coll. and leg. A. Warén).

Chrysallida eximia (Jeffreys, 1849) - Found along the whole Norwegian coast, including East Finnmark (G.O. Sars 1878, Norman 1902), although only occasionally north of Lofoten. In my material 51 specimens and 275 shells, the majority of the shells found between $63^{\circ}$ and $67^{\circ} \mathrm{N}$. In the Andfjorden area only a single shell, and none from East Finnmark. Of the 51 specimens, 30 are from the Espegrend area. Further north, surprisingly few specimens compared to the hundreds of shells found.

Chrysallida hoeisaeteri Warén, 1991 - The holotype is a specimen from the shelf outside Korsfjorden $\left(60^{\circ} 08^{\prime}\right.$ $\mathrm{N}, 270-250 \mathrm{~m}$ ). Otherwise known only from a few specimens from northern Iceland, and some shells from southeastern Iceland and eastern Greenland. In my material three samples with respectively six, three and five somewhat worn shells might belong to this species. These are from the same three stations in the outer part of Andfjorden (Bleiksdjupet and the Steinavær coral reef) as C. bjoernssoni is reported from above.

Chrysallida indistincta (Montagu, 1808) - This species has been reported as rare from the Bergen area by Friele (1874) (not refound by Norman 1879 in the same area), from Oslofjorden by G.O. Sars (1878) (not recorded by Jeffreys 1870, however), while Warén (1991) only records two specimens and one shell (from Korsfjorden) as Norwegian material. In the Koster area in the Swedish part of Skagerrak it seems to be common (Warén 1991). I have two specimens and three shells from the Wikander material from Skagerrak. In my material two specimens and an additional 18 shells (or fragments) of which two specimens and 16 shells from between $65^{\circ} 30^{\prime} \mathrm{N}$ and $67^{\circ} 05^{\prime} \mathrm{N}$. Except for the two specimens, beautifully preserved, from outer Vefsnfjorden $\left(65^{\circ} 53^{\prime} \mathrm{N}, 12^{\circ}\right.$ 32' E, 12-15 m, Desmarestia and Lithothamnion and other red algae) the shells are often worn, with much of the spiral sculpture hard to see. As the species is easily confused with $C$. interstincta, the 10 samples included here are not all to be trusted. The material from Vefsnfjorden and two shells from Sjonafjorden, just south of Sila ( $66^{\circ} 17^{\prime} \mathrm{N}, 160-80 \mathrm{~m}$, gravel) are perhaps the most reliable, all five are long (max. length almost $4 \mathrm{~mm}$ ), narrow, almost cylindrical shells, superficially Turbonilla-like, with slightly convex whorls, and with three to five spiral cords on the body whorl. The colour of preserved specimens as seen through the shell is reddish orange, and the eyes are very small and close together. The material from Sjonafjorden is also the northernmost record of this species so far.

Chrysallida interstincta (J. Adams, 1797) $[=$ Chrysallida obtusa (Brown, 1827)] - Neotype assigned and nomenclature discussed by Warén (1991). This very common, mainly shallow water species is quite variable, as is illustrated by numerous SEM-photos in Peñas \& Rolán (1998). It is possible in most samples (especially two shallow water, hard bottom stations 
just southwest of Bodø, $67^{\circ} 16^{\prime} \mathrm{N}, 13 \mathrm{~m}$, and $67^{\circ}$ $17^{\prime} \mathrm{N}, 50-20 \mathrm{~m}$ ) to distinguish two forms, one with broadly conical shape, evenly rounded whorls, the other rather narrow cylindrical, with more flattened, somewhat 'overhanging' whorls. The problem is that in good samples of live-caught specimens, the variability is covering both extremes, as is evident in a sample of 18 specimens from Hillersholmen $\left(60^{\circ} 18^{\prime}\right.$ $\mathrm{N}, 6-8 \mathrm{~m}$, coarse shell gravel). Previously reported from Lofoten (rare) and southwards (G.O. Sars 1878). In my material abundant in the Espegrend area, and sparingly further north, with a little peak in NordTrøndelag county with 13 specimens. The northernmost was a single specimen from the rich station in Gratangen (68 $44^{\prime} \mathrm{N}, 90-80 \mathrm{~m}$, fine shell sand with many Modiolula shells).

Chrysallida nivosa (Montagu, 1803) [= Odostomia nivosa - This species is better known as Jordaniella nivosa, but to be consistent I follow CLEMAM. Not previously reported from Norway, but recently reported from Læsø, Kattegat (Olesen et al. 2005). In my material 24 specimens all taken on Laminaria hyperborea from a rather exposed locality near Lyroddane outside Sotra $\left(60^{\circ} 10^{\prime} \mathrm{N}\right)$ in 1992.

Chrysallida pellucida (Dillwyn, 1817) [= Chrysallida spiralis (Montagu, 1803)] - The name change is presumably due to van Aartsen \& Gianuzzi-Savelli (1991), who discovered an older homonym to Turbo spiralis Montagu. This species is one of the few northEuropean pyramidellids recognizable at a glance, and therefore with more reliable records than most. It has been reported from the whole Norwegian coast, East Finnmark included (G.O. Sars 1878, Norman 1902). In my material one of the most abundant pyramidellids, with altogether more than 3700 specimens from the Espegrend area. In each of some 15 samples in which also were found dense aggregations of the serpulid polychaete Pomatoceros, hundreds of specimens could be found. Also common in some 25 samples with no Pomatoceros present. On the coast north of Stadt only two specimens, but more than 220 shells. The northernmost specimen is from Kvæfjorden in southern Troms $\left(68^{\circ} 50^{\prime} \mathrm{N}, 30 \mathrm{~m}\right.$, rocky bottom with lots of red algae (Ptilota plumosa?)). The other specimen from northern Norway was found at the same station as the two specimens of $C$. indistincta, in outer Vefsnfjorden $\left(65^{\circ} 53^{\prime} \mathrm{N}, 12^{\circ} 32^{\prime} \mathrm{E}, 12-15 \mathrm{~m}\right.$, Desmarestia and Lithothamnion and other red algae) The shells were primarily from Nordland south of Bodø and from Nord-Trøndelag.
*Chrysallida sarsi (Nordsick, 1972) - Its presence in Norway is based on two shells from the Bergen area mentioned in Warén (1991), who also mentions 12 specimens from the Koster area in western Sweden. Not in my material.

Chrysallida sublustris (Friele, 1886) [= Odostomia sublustris Friele, 1886] - Described from the slope from c. $66^{\circ} \mathrm{N}(640 \mathrm{~m})$ (type material according to Micali et al. 1993), $68^{\circ}(1150 \mathrm{~m})$ and $69^{\circ}$ (1187 m). Later Grieg (1915) reported a single specimen from the slope outside 'Tampen' ( $62^{\circ} 15^{\prime}$ N, $0^{\circ} 15^{\prime}$ E, 800 m). Warén (1991) added two shells from south of Jan Mayen and one shell from northeastern Iceland. In my material eight specimens from four stations, all on the slope at negative temperatures, $62^{\circ} 31.5^{\prime} \mathrm{N}, 701 \mathrm{~m}$, one specimen; $62^{\circ} 12^{\prime} \mathrm{N}, 708 \mathrm{~m}$, three specimens; $63^{\circ}$ $10^{\prime} \mathrm{N}, 830 \mathrm{~m}$, one specimen; and $63^{\circ} 13^{\prime} \mathrm{N}, 1003 \mathrm{~m}$, three specimens.

*Chrysallida truncatula (Jeffreys, 1850) - This everywhere uncommon species is represented by a single empty and brittle shell (since partly broken, coll. \& leg Wikander) from just south of Grimstad (58 $18^{\prime}$ $\mathrm{N}, 60 \mathrm{~m}$, shell sand).

Eulimella acicula (Philippi, 1836) [= Eulimella laevis (Brown, 1827)] - Warén (1991) argues for the retention of Brown's name, Eulimella laevis for this group of north European pyramidellids, although he uses the method of elimination for justifying his conclusion. Clemam lists E. laevis as a synonym of the Pleistocene fossil, Eulimella acicula (Philippi, 1836). The latter name was used exclusively by all older authors, following Jeffreys, who however did not distinguish between the shallow water 'E. laevis' and the more deep living E. ventricosa. G.O. Sars (1878) was the first to keep the two apart, and he records several specimens from Skudesnæs (c. 5909' N) which presumably he regarded as its northern limit. Norman (1879) later reported it from two stations near Bergen. Material from the Zoological Museum at the University of Bergen, shows that Friele had material from as far north as the classical locality Kinn outside Florø (c. $61^{\circ} 05^{\prime}$ N). Warén (1991) states its distribution to extend from northern Norway to the Mediterranean, but without further documentation. In my material 35 specimens and an additional 65 shells from all along the coast north to outside Bodø $\left(67^{\circ} 16^{\prime} \mathrm{N}, 13 \mathrm{~m}\right.$, coarse shell gravel and Laminaria, one specimen and two shells). The abundance of this species increases from north to south, with a maximum in Møre og Romsdal (17 specimens and 22 shells), but only slightly less in the Espegrend 
area, with 15 specimens. In addition a juvenile from the northern north Sea (east of Sleipner, 58 30' N, $87 \mathrm{~m}$ ) and the Wikander material from Skagerrak contained numerous specimens. The latter material is very variable, and I have provisionally divided it into three distinct 'forms', supporting earlier suspicions that 'E. laevis' is really a species complex.

Eulimella ataktos Warén, 1991 [= Eulimella gracilis Jeffreys, 1847 in part] - Known from the holotype from Grøtsundet, Troms (c. 69 50' N, 142-182 m) and an additional specimen from Nordre Brattholmen, Hjeltefjorden ( $60^{\circ} 24^{\prime} \mathrm{N}, 100-180 \mathrm{~m}$, gravel and coral rubble). The only later record is a single shell from the Faroes (Schander 1995). In my material at least two specimens from Kobbeleia, east of Sotra $\left(60^{\circ} 18^{\prime}\right.$ N, 70 m, fine sand, silt, Modiolula phaseolina gravel and small stones, coll. and leg. A. Warén), together with three specimens of E. ventricosa. Also a shell from the upper slope in Bleiksdjupet northwest of Andøya $\left(69^{\circ} 25^{\prime} \mathrm{N}, 700-200 \mathrm{~m}\right.$, clay mixed with fine sand and some stones).

Eulimella 'compactilis' (sensu G.O. Sars, 1878) [= Eulimella compactilis (Jeffreys) G.O. Sars, 1878] - Probably not the form Jeffreys named as a variety of $E$. scillae from the Hebrides. Warén (1991) dismisses this species as juveniles of E. scillae. G.O. Sars is positive that the two are distinct, and by comparing my material with Sars's material in the Zoological Museum, University of Oslo, I have been able to confirm his conclusion. This is a species with a very restricted distribution, being confined to deep, clayey fjord bottoms. G.O. Sars (1878) reports it from Lofoten, $350-750 \mathrm{~m}$, and also from several specimens from the western coast. In my material several samples with shells from Møre og Romsdal, of which only three specimens from Voldafjorden $\left(62^{\circ} 10^{\prime} \mathrm{N}, 650-690\right.$ $\mathrm{m}$, soft bottom) were live caught. Otherwise fairly common (a total of 33 specimens) in the Norwegian Trench (61 $\left.30^{\circ} \mathrm{N}, 311 \mathrm{~m}\right)$, and the soft bottoms of the deep fjords around Bergen (300-450 m).

Eulimella scillae (Scacchi, 1835) - Recorded from all along the coast north to the Barents Sea at almost $71^{\circ} \mathrm{N}$ (Friele \& Grieg 1901). In my material 13 specimens and an additional 55 shells. Three samples with two specimens and one shell in the Wikander material from Skagerrak. Nine samples with 11 specimens from the Bergen area, most of them coll. and leg. A. Warén. From the five cruise series, 24 samples of shells, but only two specimens, one from Bindalsfjorden and one from Foldafjorden. The species seems to be fairly evenly distributed along the coast. It is found in intermediate depths on mixed bottoms e.g. silty shell sand. Many of the specimens from hauls taken up steep rocky slopes with ledges.

Eulimella ventricosa (Forbes, 1844) [= Eulimella gracilis Jeffreys, 1847] - Probably the commonest Eulimellaspecies on the Norwegian coast, and known as far north as the southern Barents Sea $\left(70^{\circ} 55^{\prime} \mathrm{N}\right.$, Friele $\&$ Grieg 1901). Two samples with one specimen and one shell in the Wikander material from Skagerrak. In my material 24 specimens and an additional 125 shells, the northernmost specimen is from a sample from outside Kristiansund ( $63^{\circ} 09^{\prime}$ N, 145 m, sand), and the northernmost shell from the upper slope northwest of Andøya (69 $25^{\circ} \mathrm{N}, 700-200 \mathrm{~m}$, clay mixed with fine sand and some stones).

*Eulimella n. sp. - A specimen in the Zoological Museum, University of Bergen, from Korsfjorden, $360 \mathrm{~m}$, determined to Eulimella acicula $\mathrm{Ph}$. by Friele (Friele 1876:6), is unique in the Norwegian fauna for its size. Sixteen whorls and a length of $11 \mathrm{~mm}$ is far more than for any other species. A single shell from Tomfjorden (66 $15.5^{\prime} \mathrm{N}, 380-300 \mathrm{~m}$, mixed bottom) may belong to the same species. Probably undescribed.

Odostomia spp. - Following CLEMAM, here defined broadly including both Brachystomia Monterosato, 1884 and Megastomia Monterosato, 1884.

Odostomia acuta Jeffreys, 1848 [including Odostomia umbilicaris (Malm, 1863)] - van Aartsen (1987) concluded that $O$. umbilicaris is a synonym of $O$. acuta. Reported from all along the coast, with the exception of East Finnmark (G.O. Sars 1878). Found in large numbers on the gelatinous tubes of the polychaete Myxicola infundibulum (Høisæter 1989). Sixteen samples with 53 specimens in the Wikander material from Skagerrak. In my material competing with $O$. turrita and $O$. unidentata in being the commonest species of Odostomia (s. str.). Specimens inspected alive are easy to identify, but long dead shells are hard to distinguish from 0 . unidentata. I have identified 134 specimens (of which 104 from the Espegrend area) and an additional 200 shells as belonging to this species. The northernmost shells recorded from a station in Andfjorden, east of Andøya (69 $19^{\circ} \mathrm{N}$, 65-80 m, coarse shell gravel). Otherwise fairly evenly distributed along the coast.

*Odostomia cf. angusta (Jeffreys, 1867) [= Odostomia (Brachystomia) eulimoides Hanley, 1844 in part] - This species has not been reported from Norwegian waters, but the localities listed by Jeffreys (1867: 125, 
from Guernsey to Shetland), makes it likely that it should also be found in our waters. It belongs to the problematic group of 'Odostomias' with submerged protoconch, comprising also O. carrozzai, O. eulimoides, and $O$. scalaris. The only source for identifying this species is a photograph in van Aartsen (1987), showing a shell much like O. eulimoides, but somewhat narrower. The main character van Aartsen mentions for distinguishing the two is that $O$. eulimoides is stated to have clearly prosocline growth-lines, while those of $O$. angusta are more or less vertical. This distinction is easily visible only on very fresh material. In view of these cautions, I have provisionally named this category Odostomia cf. angusta. I have assigned two specimens and an additional 10 shells to this category, all taken between $62^{\circ}$ $28^{\prime} \mathrm{N}$ and $67^{\circ} 15^{\prime} \mathrm{N}$.

Odostomia carrozzai (van Aartsen, 1987) [= Odostomia albella (Lovén, 1846)] - This is a replacement name for O. albella auct., not Lovén, 1846, which van Aartsen (1987) discovered was based on a specimen of $O$. unidentata. Recorded by Norman (1879) from Bukkasundet, very shallow water and intertidally. I have assigned 10 specimens and an additional four shells to this category. Seven of the specimens are from a single station at Hillersholmen $\left(60^{\circ} 18^{\prime} \mathrm{N}\right)$. The identifications are tentative, and among the 14 , several are probably misidentified. The most convincing shell is a single one from Foldafjorden $\left(64^{\circ}\right.$ $40^{\prime} \mathrm{N}, 60-20 \mathrm{~m}$, shell gravel large amounts of tubes of the serpulid polychaete Hydroides.)

Odostomia conoidea (Brocchi, 1814) - Reported from the southern and western coast by G.O. Sars (1878) and from the Bergen area by Norman (1879). Thirteen samples with altogether 12 specimens in the Wikander material from Skagerrak. In my material 29 specimens and an additional 54 shells, more or less evenly distributed north to Bindalsfjorden (c. $65^{\circ}$ $\mathrm{N})$. Further north a single specimen in Saltfjorden (67 $10^{\circ}$ N, 170-90 m, Modiolula phaseolina bottom). A species found mostly at intermediate depths, from 50-60 to $200 \mathrm{~m}$.

Odostomia conspicua Alder, 1850 - Reported from the Skagerrak coast ('Ora meridion. Norv.'), 35-55 m by G.O. Sars (1878). In the Wikander material from Skagerrak, seven specimens from five stations. Not found further north along the coast.

Odostomia eulimoides (Hanley, 1844) [= Odostomia (Brachystomia) eulimoides Hanley, 1844 in part] - Reported by G.O. Sars (1878) from outside Bodø where it was rather common on the ears of Chlamys islandicus. The only other Norwegian locality mentioned is Florø. Apparently not reported later from Norway. (The many specimens reported in Høisæter (1989) from Pomatoceros are due to a misidentification and really refer to Odostomia striolata). From further south in Europe the species is reported to parasitize Pecten maximum, Aequipecten opercularis, and sometimes Turritella. In my material two specimens taken off the ears of Pecten maximus from the Skagerrak coast (coll. and leg. P. Buhl Mortensen) are included as the only uncontroversial specimens. All other potential members of the species are included in the $O$. cf. angusta complex mentioned above.

Odostomia lukisi Jeffreys, 1859 [= Odostomia (Brachystomia) lukisi Jeffreys, 1858] - A southern, shallow water species only recorded from the Espegrend area except for a single older record from Florø (Høisæter 1968). In my material 237 specimens from 13 samples, all but two from the locality in Knappensundet (Straume bridge) in Grimstadfjorden $\left(60^{\circ} 19^{\prime} \mathrm{N}\right)$.

*Odostomia cf. plicata (Montagu, 1803) - Has been recorded at various times as a Scandinavian species, but every time refuted by a later author. I have looked at a couple of the shells Friele (1874) assigned to $O$. plicata, which were later dismissed as misidentifications by G.O. Sars (1878) and Norman (1879). These were from Kvarven, just outside Bergen harbour. They might be shells of $O$. turrita, although they had more whorls and were much narrower than any of the hundreds of specimens of $O$. turrita I have seen. The shape of the body whorl and aperture were also unlike $O$. turrita. Unfortunately the aperture was partly broken in both of the shells from Kvarven. The length-width proportion is much like in the illustration in van Aartsen (1987), but his photograph shows a shell with a very narrow spire, and an almost concave outline, while $O$. turrita and the two shells from Kvarven has a slightly convex outline. Until further material is available, this species must be treated as a doubtful record for Norway.

Odostomia scalaris MacGillivray, 1843 [= Odostomia (Brachystomia) rissoides Hanley, 1844] - Formerly this species has been reported as far north as Trondheimsfjorden $\left(63^{\circ} 30^{\prime} \mathrm{N}\right)$ but this is partly based on my preliminary identifications of the present material. Published records from Norway from before 1986 are scarce. Norman (1879) reports it from Raunefjorden and Osterfjorden and cites earlier reports from Oslofjorden (from Jeffreys 1870). G.O. 
Sars (1878) records it from Oslofjorden, the southern coast and the west coast. Thirteen samples with 34 specimens in the Wikander material from Skagerrak. It seems to be a typical shallow water species, rarely found alive deeper than $20 \mathrm{~m}$ in our waters. It has most frequently been encountered as an ectoparasite of Mytilus edulis, but has been reported from a number of other molluscan hosts as well as free living in shallow water. In my material 738 specimens of which 705 from the Espegrend area. Further north 33 specimens and 39 shells, the northernmost empty shell from southwest of Bodø $\left(67^{\circ} 15^{\prime} \mathrm{N}, 50-20 \mathrm{~m}\right.$, shell gravel, slag and small stones). A sample from a shallow water algae station (containing more than 1200 Bittium reticulatum) at Fløan, bay southeast of Stamnes (64 29' N, 3-10 m, soft bottom with Laminaria saccharina, Chorda filum and other algae) contained at least $30 \mathrm{O}$. scalaris. This is thus at present the northern limit for the species. In the Espegrend area, the species has been collected from samples containing numerous Limaria hians, also from samples of Pomatoceros 'reefs', and finally from haptera and stipes of Laminaria hyperborea in semi-exposed and fairly protected areas. In the first and last of these it was invariably the most numerous pyramidellid species.

Odostomia striolata Forbes \& Hanley, 1850 [= Odostomia eulimoides Hanley, 1844 in part] - This species was re-introduced (after having been neglected for nearly 140 years) by van Aartsen et al. (1984). Not previously reported from Norway, but mistakenly named O. eulimoides in Høisæter $(1986,1989)$. In the years 1965-1968 the commonest species of Odostomia in the Espegrand area, from where I have nearly 17000 specimens, almost all associated with the serpulid Pomatoceros. Surprisingly few samples of this species in the material from the summer cruises, only three samples from Møre og Romsdal, with three specimens and a further five shells. The northernmost of these is a sample of two specimens from Frenefjorden ( $62^{\circ} 50^{\prime} \mathrm{N}, 62-50 \mathrm{~m}$, sand).

Odostomia cf. turgida G.O. Sars, 1878 - G.O. Sars described $O$. turgida from a few empty shells from 90-110 $\mathrm{m}$ in Lofoten, and mentioned that Jeffreys had some material of the same species from Finnmark. Van Aartsen (1987) after having inspected the holotype considered that $O$. turgida was a synonym of $O$. unidentata. In my material some shells from northern Norway with a large protoconch are definitely different from $O$. unidentata, and also from the characteristic $O$. conspicua, which in Norway seems to be confined to the Skagerrak coast. I have not yet been able to study Sars' type material, and his drawing is not sufficiently detailed for a definite conclusion, but regard it as not unreasonable to identify my material with his species. In my material 12 shells from six stations. One of these from the very species rich station in Sandfjorden, near the open coast just north of Stadt ( $62^{\circ} 16^{\circ} \mathrm{N}, 50-25 \mathrm{~m}$, shell sand and gravel). Shells (and a few specimens) of 15 other species of pyramidellids were found at the same station. All the remaining shells were taken from stations between $66^{\circ} \mathrm{N}$ and $67^{\circ} 03^{\prime} \mathrm{N}$.

Odostomia turrita Hanley, 1844 - Reported from the whole coast, excluding East Finnmark by G.O. Sars (1878). Norman (1902), based on literature records, included O. turrita in his list from East Finnmark. Not mentioned in Friele \& Grieg (1901). Ten samples with 34 specimens in the Wikander material from Skagerrak. In my material 8600 specimens and an additional 450 shells. The northernmost shell from Andfjorden, east of Andøya ( $69^{\circ} 17^{\prime} \mathrm{N}, 65-80 \mathrm{~m}$, coarse shell gravel). The northernmost specimen from Glomfjorden $\left(66^{\circ}\right.$ $49^{\prime} \mathrm{N}, 120-60 \mathrm{~m}$, stones). Otherwise found in all sectors southwards, but whereas $O$. unidentata is increasing in abundance northwards, $O$. turrita is decreasing. This is yet another of the species predominantly associated with Pomatoceros.

Odostomia unidentata (Montagu, 1803) - Reported from the entire coast, including East Finnmark by G.O. Sars (1878). Ten samples with 46 specimens in the Wikander material from Skagerrak. In my material 3500 specimens and an additional 650 shells. One specimen at each of three stations in the Kvæfjord/Grovfjord/Gratangen area (c. $68^{\circ} 40-45^{\prime}$ $\mathrm{N})$. Otherwise evenly distributed along the coast southwards, but slightly more abundant than $O$. turrita in all sectors. The association with Pomatoceros is not quite as strong as for O. striolata, O. turrita, and Chrysallida pellucida.

*Odostomia $\mathrm{n}$. sp. - This is based on a single, very characteristic shell from north west of Skorholmen, Korsfjorden $\left(60^{\circ} 09^{\prime} \mathrm{N}, 200-75 \mathrm{~m}\right.$, steep rocky slope with pockets of shell gravel, coll. and leg. A. Warén). This is a fairly narrow and solid shell, $3.05 \mathrm{~mm}$ long with c. five whorls. The whorls are well rounded with a deep and somewhat channeled suture. The tilted protoconch is approaching the situation for Odostomia striolata although somewhat more protruding. The shell has a wide and deep umbilicus, and the columellar 'tooth' is weak and retracted but distinct. The species is probably no Odostomia, but no other north European genus seems to fit. 
Liostomia afzelii Warén, 1991 [= Menestho (Liostomia) clavula in part] - Described from material from the Koster area on the Swedish west coast. A single specimen from Korsfjorden 150-300 m was mentioned as additional material in the description. In my material two specimens and an additional three shells from Møre og Romsdal. The two specimens are from the species rich sample from Breisunddjupet $\left(62^{\circ} 29^{\prime}\right.$ $\mathrm{N}, 120-60 \mathrm{~m}$, shell sand), which is thus the present northern limit for the species (but see L. clavula below). Five specimens in the Wikander material from Skagerrak, also most likely belong to L. afzelii.

Liostomia clavula (Lovén, 1846) [= Menestho (Liostomia) clavula in part] - A single shell reported by G.O. Sars (1878) from Lofoten, who also found a number of specimens from Tananger outside Stavanger (58 56' N) and a single shell from Oslofjorden. Friele (1874) reported a single specimen from Bergen (see Ondina diaphana below). As these early authors did not distinguish between $L$. afzelii and L. clavula some or all of these records might refer to L. afzelii (judging from the drawing in G.O. Sars, the shell from Lofoten most likely belongs to L. afzelii). Warén (1991) confirmed its presence in Norway by the find of two specimens in Korsfjorden, 150-300 m. A single specimen in the Wikander material from Skagerrak. In my material 10 specimens and an additional 16 shells from several samples from Møre og Romsdal county, the northernmost from Frenefjorden $\left(62^{\circ} 50^{\prime} \mathrm{N}, 62-50 \mathrm{~m}\right.$, sand) containing six specimens and nine shells.

Liostomia eburnea (Stimpson, 1851) [= Menestho (Liostomia) eburnea and including Menestho (Liostomia) nitida (Friele, 1876 ex M. Sars MS)] - Discussed by Warén (1991) who also argues for the synonymy of Jeffreysia nitida Friele with L. eburnea. All the Norwegian records of this latter species are from Varangerfjorden (12 specimens plus a few shells according to Warén) while the single known shell of $J$. nitida was taken by M. Sars near Florø. Warén did not succeed in locating this shell, and his decision is thus based on comparing the drawings and description of Friele with his material of $L$. eburnea. Friele compared the actual specimen with Stimpson's drawing of L. eburnea, and found them easy to separate. Whether or not the two are the same species, is an open question (because of the widely different localities, I find it unlikely), but in any case I see no reason to retain $L$. nitida as a species in the Norwegian fauna. I agree with Warén that the generic placement of L. eburnea is just a matter of convenience, no other described genus seems to fit. Not in my material.
Liostomia hansgei Warén, 1991 - Described from five specimens from the Koster area, western Sweden. Additional material three specimens and two shells from Korsfjorden and the outer part of Fanafjorden $\left(60^{\circ} 12-14^{\prime} \mathrm{N}, 150-280 \mathrm{~m}\right)$. Not in the Wikander material from Skagerrak. In my material seven specimens of which six are from the Espegrend area, mostly from the outer part of Fanafjorden, 140-220 m. Apparently the commonest species of Liostomia in the area around Bergen. In addition to the material from Fanafjorden/Korsfjorden, two shells from around $63^{\circ} 10^{\prime} \mathrm{N}-63^{\circ} 15^{\prime} \mathrm{N}(110-145 \mathrm{~m}$, soft to sandy bottom). Finally a single specimen from Tomfjorden (66 $15^{\circ} \mathrm{N}, 380-300 \mathrm{~m}$ ) and two shells from locations in the same general area but from somewhat shallower depths (80-160 m, mostly rather soft bottom).

Ondina spp. - Species of this genus have very few diagnostic conchological characters, and in spite of two thorough recent revisions (van Aartsen 1987, Warén 1991) there are still problems in correctly identifying specimens of many of these species.

*Ondina coarctata (G.O. Sars, 1878) [= Menestho coarctata] - So far known from three shells from Hasvik in western Finnmark (70 30' N, 90-180 m, G.O. Sars 1878) and a shell from Hammerfest $\left(70^{\circ} 40^{\prime}\right.$ N, 90-110 m) from the Norwegian North-Atlantic Expedition, identified by Friele (ZMB 21 623). I have one shell, $3.85 \mathrm{~mm}$ long, from Vevelstadsundet $\left(65^{\circ}\right.$ $42^{\prime} \mathrm{N}, 65-45 \mathrm{~m}$, sand and shell gravel), and another from Grovfjord ( $68^{\circ} 41^{\prime} \mathrm{N}, 20-40 \mathrm{~m}$, stones and coarse shell sand, much Ptilota). The latter has unfortunately not been available for reevaluation. Another shell most likely belonging to this species is from Støttsundet northwest of Ørnes in Meløy (66 $56^{\prime} \mathrm{N}$, 24-18 m, Laminaria and shell sand). I have compared my specimens to the specimen from Hammerfest mentioned above, and find the correspondence reasonable, although my specimens (especially the body whorl) is slightly more 'shouldered' than the museum shell.

Ondina diaphana (Jeffreys, 1848) [= Menestho diaphana] - A single specimen recorded by Friele (1874) from $110-130 \mathrm{~m}$ in Bergen (c. $60^{\circ} 25^{\prime} \mathrm{N}$ ) together with one Liostomia clavula and several Ondina divisa. This record has been accepted by G.O. Sars (1878), and Norman (1879), but is not mentioned by Warén (1991). In the Zoological Museum in Bergen, a shell from Florø is stated to be identified by Jeffreys. The main difference from the far more common O. divisa, is the complete lack of spirals and a comparatively larger body whorl. Van Aartsen (1997) and Warén 
(1991) disagree concerning the possible synonymy of $O$. perezi with $O$. diaphana. While Warén, in line with Kristensen (1970), Rodriguez Babio \& ThiriotQuiévreux (1975) and several other authors, maintain that the two are synonymous, van Aartsen followed by Schander (1995) keeps them apart, and so do Killeen \& Smith (1991), although based on rather indirect evidence. If the two are distinct $O$. diaphana should be smaller (according to van Aartsen around $1.6 \mathrm{~mm}$ long), more slender and more shiny. In my material only a few undisputable specimens and shells from two stations, both from Møre og Romsdal county, in the outer archipelago in the southern part of the county (around 62 $15^{\prime}$ to $20^{\prime} \mathrm{N}$ ), in two dredge hauls from between 25 and $50 \mathrm{~m}$, sand, gravel and stones, and large shell fragments.

Ondina divisa (J. Adams, 1797) [= Menestho divisa - By far the commonest species of Ondina in Norwegian waters, but several morphotypes can be distinguished in my material. The possibility of several species being involved cannot be rejected. Found all along the coast at least north to $68^{\circ} \mathrm{N}$. In my material some 150 specimens and 200 shells from 50 stations, the northernmost are two empty (and rather eroded) shells from deep water in outer Andfjorden, (c. $69^{\circ}$ $20^{\prime}$ N). G.O. Sars (1878) reports a variety (var. nobilis) from Hasvik in western Finnmark (70 $30^{\prime} \mathrm{N}$ ), which should be appreciably larger, with higher spire and deeper suture, and have much finer spiral sculpture. This is the only record from north of Lofoten, and whether it is a distinct species or only a variety is still an open question.

Ondina normani (Friele, 1886) [= Menestho normani] - Earlier known only from the type material (Florø, 54 m, Warén 1991) and outer Sognefjorden, and two specimens and five shells from Tromsø (Schander 1995). In my material 16 specimens and an additional five shells from all around the coast from Saltfjorden $\left(67^{\circ} 10^{\prime} \mathrm{N}, 170-90 \mathrm{~m}\right.$, Modiolula phaseolina substrate) to the Skagerrak coast. Thus the species seems to be fairly common in Norwegian waters.

Ondina obliqua (Alder, 1844) [= Menestho obliqua - Recorded from western Norway by G.O. Sars (1878) without further information. Not mentioned in Norman (1879). Warén (1991) questions Sars' record. In my material a large specimen from Fitjar $\left(59^{\circ} 54^{\prime}\right.$ $\mathrm{N}, 18 \mathrm{~m}$, leg. Per Johannessen) and a single old and worn shell from Raunefjorden (Hillersholmen, c. $60^{\circ}$ $18^{\prime} \mathrm{N}, 8 \mathrm{~m}$, coarse shell gravel), possibly subfossil.
*Ondina perezi (Dautzenberg \& Fischer, 1925) [= Menestho diaphana in part] - As discussed under Ondina diaphana, authorities disagree as to whether $O$. perezi is a good species or only a synonym of $O$. diaphana. If $O$. perezi is accepted as a valid species, a close association with Phascolion strombi within the aperture of a host shell is a strong indication that it is actually $O$. perezi. In my material a single specimen from Grimseidpollen (c. $60^{\circ} 16^{\prime} \mathrm{N}, 13-15 \mathrm{~m}$, coll. and leg. S. Bakke 1964) found within the aperture of a Littorina shell inhabited by Phascolion strombi. Unfortunately it is partly broken and rather corroded by acidic conditions, and not easily identifiable in its present condition. According to notes made at the time of collection it possess all species specific characters.

Ondina cf. warreni (Thompson, 1845) [= Menestho warreni] - This species has been reported twice from Norwegian waters, from Oslofjorden 75-110 m (Jeffreys 1870), and from Raunefjorden, $180 \mathrm{~m}$ (Friele 1874:22). The latter record was repeated in the Synoptic Tables in G.O. Sars (1878), but retracted by Friele himself (in Norman 1879:60). Warén (1991) mentions the report in G.O. Sars (whose determination he questions), but fails to refer to Jeffreys (1870). The general distribution of the species is the western Irish and British coasts between 30 and $60 \mathrm{~m}$ on gravelly and sandy mud (Graham 1988). Warén (1991) presents a SEM-photo of a specimen from Shetland. Altogether 15 specimens in four samples from the Wikander material from Skagerrak resemble Warén's SEM-photo of $O$. warreni more than any form of $O$. divisa in my material. The most 'diagnostic' differences distinguishing $O$. cf. warreni from $O$. divisa are: wider and with more whorls at same length, very fine overall spiral striation in addition to coarse spirals at lower part of body whorl, and somewhat wider umbilicus.

*Rissopsetia cf. islandica Warén, 1989 - This species was described from Skeidaradypi, southeastern Iceland, and reported to be found in southeastern Greenland, western and southern Iceland in 200-900 m. Warén (in litt 2008) confirms that, based on living material, his species is indeed a pyramidellid. In my material a single somewhat broken shell from Bleiksdjupet northwest of Andøya, (69 $25^{\circ} \mathrm{N}, 200-700 \mathrm{~m}$, stones and clay).

Turbonilla spp. - As used in CLEMAM and thus here, this is an artificial group (as is Chrysallida s.l., and Odostomia s.1.). As is evident from both conchological and molecular genetic data T. crenata, T. rufa and 
T. rufescens should be assigned to Pyrgiscus Philippi, 1841, which is only distantly related to Turbonilla s.str. The systematics of Turbonilla s.str. in North European waters is confusing to say the least, and different authors have widely different ideas on how to subdivide the group. As an example, Graham (1988) (following Fretter, Graham \& Andrews 1986) accepts three species from British water, T. lactea (Linné, 1767), T. pusilla (Philippi, 1844) and T. acuta (Donovan, 1804). Smith \& Heppell (1991) list no less than seven species from the same area. (In addition to the three mentioned above: T. innovata (Monterosato, 1884), T. delicata (Monterosato, 1874), T. magnifica (Seguenza 1879), and T. multilirata (Monterosato, 1874)). Both sources (and perhaps also CLEMAM) base their concepts of the different species on van Aartsen (1981). How many and which of the British species are found in Norwegian waters is hard to say, as the variability of conchological characters within the genus is known to be large, and available illustrations are not very helpful regarding the degree of variability. What is certain is that Turbonilla s.str. is primarily a southern group in Europe, and few if any species extend further north than the Norwegian Skagerrak coast. While the species of Turbonilla s.str. in Norwegian waters are extremely hard to identify, the three species of Pyrgiscus seem to be quite straightforward.

Turbonilla crenata (Brown, 1827) [= Turbonilla interrupta (Totten, 1835)] - Reported by G.O. Sars (1878) from Lofoten, but only from a single $8.5 \mathrm{~mm}$ long specimen. Also recorded from Trondheimsfjorden, from a single specimen (Norman 1893). Friele (1874) and Norman (1879) both report it from the Bergen area, Friele states it to be rather common in the area. G.O. Sars also has records from western and southern Norway. Seven samples with 12 shells but only a single specimen in the Wikander material from Skagerrak. In my material 13 specimens (of which eight from the North Sea) and an additional 22 shells from the Espegrend area north to Vevelstadsundet (65'42' N, 65-42 $\mathrm{m}$, sand and shell gravel, living) and south west of Bodø $\left(67^{\circ} 16^{\prime} \mathrm{N}, 13 \mathrm{~m}\right.$, coarse shell gravel and Laminaria, empty shell).

*Turbonilla lactea (Linné, 1767) [= Turbonilla elegantissima (Montagu, 1803)] - Reported by several early authors, but removed from the list of Norwegian species by G.O. Sars (1878). Probably not living in Norwegian waters today. However, this group of Turbonilla s.l. is in a very confused state. Not in my material.
Turbonilla cf. pusilla (Philippi, 1844) - One specimen and six shells of Turbonilla s.str. from the Wikander material from Skagerrak. Most probably all belong to the variable $T$. pusilla (sensu Aartsen 1981), but one long and slender shell might belong to another species.

Turbonilla rufa (Philippi, 1836) - By most experts, e.g. Smith \& Heppell (1991), regarded as a synonym of T. crenata, but definitely a good species. A single specimen, $4.4 \mathrm{~mm}$ long from a station in Ryfylke (15 m, soft bottom, 27/8 2007, coll. P. J. Johannessen). Earlier reported with a query from the Swedish west coast (Schander pers. commn., and Warén in Hansson 1998).

Turbonilla rufescens (Forbes, 1846) - There are a few, scattered records of this species in the old literature. G.O. Sars (1878) reports it from his three southern regions ('Ora occident., 'Ora meridion.', and 'Sinus Christianensis') but with no further information. Friele (1874) reports it as rare from two localities just north of Bergen, while Norman (1879) mentions two localities in Korsfjorden and Raunefjorden. Twentyone specimens and one shell in the Wikander material from Skagerrak. In my material 16 specimens and an additional 36 shells from the Espegrend area (11 specimens) north to Fugløyfjord (67 $01^{\circ}$ N, 70-50 $\mathrm{m}$, stones shells of Modiolula phaseolina) living, and $67^{\circ} 15^{\prime} \mathrm{N}$, empty shells.

Bacteridium cf. carinatum (de Folin, 1870) - Three samples from the inner, deeper parts of Fensfjorden (stations 5 $(580 \mathrm{~m})$ and $6(690 \mathrm{~m})$ in the 1972 survey) contained a few tiny pyramidellid looking shells. Three or four of them were live caught, and they were without eyes. Very loose windings, somewhat like Chrysallida truncatula, but much smaller (all less than two $\mathrm{mm}$, and $0.6-0.7 \mathrm{~mm}$ wide). Unfortunately all had lost their protoconchs, making any attempts at identification provisional. Two species from the Spanish Mediterranean are similar to my material, Ebala trigonostoma (de Folin, 1870), and Bacteridium carinatum (de Folin, 1870), the former described from the Suez Canal and the latter from Senegal. I find the relationship to Bacteridium most likely, both the channeled suture, somewhat flattened whorls and a certain sturdyness and shape of the aperture point to a relationship with $B$. carinatum. Bacteridium carinatum (the only described species) has so far not been found north of the Mediterranean coast of Spain, otherwise it lives in western Africa, north to Tunisia. 
Ebala nitidissima (Montagu, 1803) - This species is primarily found in Zostera meadows, and was first reported from Norway by Høisæter (1968). Wikander (1990) reports five specimens in a sample from a bay inside Risøya $\left(58^{\circ} 40^{\prime} \mathrm{N}\right)$ near Tvedestrand. In my material 14 specimens from three stations in Hordaland and one in Sør-Trøndelag, Gjesvik in Valsfjorden ( $63^{\circ} 48^{\prime} \mathrm{N}$, two m, Zostera on fine sand). This is probably its northern limit, as the northern limit $\left(65^{\circ} \mathrm{N}\right)$ mentioned in Høisæter (1986) was due to a misprint.

Cima cuticulata Warén, 1993 - Described from material from Korsfjorden $\left(60^{\circ} 12^{\prime} \mathrm{N}, 280-200 \mathrm{~m}\right)$ and one shell from Gjerdingen in Nord-Trøndelag (64 $58^{\circ}$ $\mathrm{N}, 80-30 \mathrm{~m}$ ). The latter is from a very species rich sample from the 1969 cruises, but I have not seen the shell. The placement in Cima is provisional, and I agree with Warén that studies of the soft parts will probably show that it belongs elsewhere.

Cima cf. cuticulata - Based on two shells from the slope just north of the 'mouth' of the Norwegian Trench (c. $62^{\circ} 32^{\prime} \mathrm{N}, \mathrm{c} .01^{\circ} \mathrm{E}, 701$ and $804 \mathrm{~m},-0.9^{\circ} \mathrm{C}$ ). Both specimens are $1.6 / 1.7 \mathrm{~mm}$ long, with c. four whorls. The specimens have a thick lamellose, yellowish periostracum covering the white shell. The periostracum tends to flake off when drying after having been kept in ethanol. The whorls are flattish and the suture is not channeled. The protoconch is large, bulbuous, smooth and glossy. The two shells fit very well the descriptions and SEM-photos in Warén (1993) except for the size, my specimens are around $20 \%$ longer with same number of whorls than the shells described by Warén. My two specimens are from negative temperatures from 700 and $800 \mathrm{~m}$, while the material on which Warén based his description was from much shallower shelf waters and positive temperatures. More material is needed before it can be decided if they are separate or not.

Cima inconspicua Warén, 1993 - Previously recorded from Tromsøysundet $\left(69^{\circ} 42^{\prime} \mathrm{N}\right)$ and western Norway (17 stations from $60^{\circ} 07^{\prime} \mathrm{N}$ to $60^{\circ} 24^{\prime} \mathrm{N}$ ). A fairly common microgastropod on deep, soft fjord bottoms north to at least $62^{\circ} 30^{\prime} \mathrm{N}$, and down to $600-700 \mathrm{~m}$ depth. In my material a total of 49 specimens, including 13 specimens from the Norwegian Trench at $61^{\circ}$ $30^{\prime} \mathrm{N}, 840 \mathrm{~m}$ depth. A single shell from $66^{\circ} 15^{\prime} \mathrm{N}$, 380-300 $\mathrm{m}$ depth may belong to this species as well. The majority (15) of my specimens from the inner, deeper parts of the Fensfjorden system (stations 47 in the 1972 survey), taken by Beyer's Epibenthic sledge.
Cima minima (Jeffreys, 1858) - The only published record from Norway is the one in Høisæter (1986), which is based on altogether 69 specimens from 11 shallow water stations in the Espegrend area (Hillersholmen, $\left.60^{\circ} 18^{\prime} \mathrm{N}\right)$.

Graphis spp. - In CLEMAM this genus is placed in the family Cimidae, although most other sources (e.g. Smith \& Heppell 1991, Cachia et al. 1996 and Rosenberg 2005) follow the traditional placement in Aclididae. Rosenberg (2005) clearly disagrees with CLEMAM in that he follows Warén (1993) in transferring Cima to a separate, heterobranch family, Cimidae, while Graphis is retained in Aclididae. Recently (Barros et al. 2003) it is placed in a separate subfamily, Graphidinae, within the Aclididae. To my knowledge no one has investigated the soft parts of any species within the genus, so the higher level placement, based exclusively on conchological characters, remains conjectural. For consistency I follow CLEMAM.

Graphis albida (Kanmacher, 1798) - Previously recorded from western Norway by G.O. Sars (1878). In my material a single somewhat eroded shell from Sandfjorden $\left(62^{\circ} 16^{\prime} \mathrm{N}, 50-25 \mathrm{~m}\right.$, shell sand and gravel).

Tjaernoeia exquisita (Jeffreys, 1883) - Discussed in Warén (1991), in which T. exquisita was reported from the Swedish west coast. In my material a sample of 17 specimens from the North Sea, E of Sleipner $\left(58^{\circ}\right.$ $30.4^{\prime} \mathrm{N}, 01^{\circ} 59.4^{\prime} \mathrm{E}, 87 \mathrm{~m}, 5.9^{\circ}$ ) which are most likely T. exquisita. A single specimen from the shelf west of Korsfjorden $\left(60^{\circ} 07^{\prime} \mathrm{N}, 4^{\circ} 50^{\prime} \mathrm{E}, 330-322 \mathrm{~m}\right.$, sand with some sponges and ascidians, coll. \& leg. Anders Warén) probably also belongs to this species.

Tjaernoeia n. sp. - Two specimens from Fanafjorden $\left(60^{\circ}\right.$ 14' N, 135-145 m, soft bottom, coll. \& leg. E. Oug) and a single specimen (unfortunately later lost), from southwest of Fiksneset, Korsfjorden (60 09’ N, 390$420 \mathrm{~m}$, silt and clay and lots of Rhabdammina, coll. $\&$ leg. Anders Warén) probably belong to Tjaernoeia, but hardly to $T$. exquisita. The specimens are even smaller, with a flatter apex, and less flaring aperture, but the small pits are similar if even smaller than in $T$. exquisita. An aspect of T. exquisita not emphasised in Warén (1991) is the set of dense growth lines covering the last whorl. Such growth lines are not obvious in these two specimens. The proportions and general aspect is much like the shell illustrated in Warén (1991: Fig. 23 F) as T. unisulcatus (Chaster), but I have not been able to see any trace of a sulcus. My specimens are also much smaller than the illustrated shell. 
Acteon tornatilis (Linné, 1758) - According to G.O. Sars (1878) found from Lofoten and south along the coast to (and including) Oslofjorden. A summary of the west Norwegian records (altogether six records from Hardangerfjorden to Sognefjorden) is presented in Grieg (1914). Soot Ryen (1951) extended its northern distribution to Vannøy, $70^{\circ} 14^{\prime} \mathrm{N}, 240 \mathrm{~m}$. Odhner (1939) reports three finds from Trondheimsfjorden, and Sneli (in litt) claims that it is common in suitable habitats within the fjord. Altogether six specimens reported from Skagerrak by Wikander (1989, 1990). In my material a single juvenile shell from the northern North Sea $\left(58^{\circ} 30^{\prime}\right.$ N, 87 m). Another old looking shell from Vefsnfjorden ( $65^{\circ} 59^{\prime}$ N, 200-40 m, mostly rocky bottom). Apparently a more common species on the south coast than further north.

Diaphana globosa (Lovén, 1846) [= Diaphana minuta Brown, 1827 in part] - Diaphana spp. has been revised by Schiøtte (1998), and he reinstated both $D$. globosa and D. hiemalis, which had been synonymized with $D$. minuta for at least 50 years. According to Schiøtte, D. globosa has been recorded from the Norwegian coast from the Swedish border north to at least off Tromsø (c. 69 $40^{\prime} \mathrm{N}$ ). Mostly in rather deep water $(150-700 \mathrm{~m})$, but occasionally found at $25 \mathrm{~m}$ depth (e.g. in the North Sea). In my material 15 specimens and an additional 18 shells from the Espegrend area (8 specimens) north to Saltfjorden (67 10' N, 170-90 m, Modiolula phaseolina bottom, two specimens).

Diaphana hiemalis (Couthouy, 1839) [= Diaphana minuta Brown, 1827 in part, and Utriculopsis vitrea M. Sars, 1870] - Recently (1998) re-separated from $D$. globosa by Schiøtte. Schiøtte also resolved a longstanding confusion regarding the name Utriculopsis vitrea, see discussion under Philine infortunata below. According to Schiøtte D. hiemalis is a true 'deep-water' species, with its main distribution in Norwegian waters north of $62^{\circ} \mathrm{N}$. In Schiøtte's revision, only a single specimen from the Espegrend area, from silty/clayey bottom, $680 \mathrm{~m}$ in Korsfjorden. In my material 32 specimens and 10 shells from the Espegrend area and north to Saltfjorden (one specimen together with D. globosa, see above). If the diagnostic characters described in Schiøtte are to be trusted, this is the dominating Diaphana-species in the deeper parts of the Fensfjorden-system. Of the 28 specimens recorded from the Espegrend area, at least 23 are from the two Fensfjorden investigations. Appear to be one of only five or six shell-bearing gastropods characteristic of deep water (deeper than about $400 \mathrm{~m}$ ), clayey bottoms in western Norwegian fjords. It also appears to be common on the slope. In my material with 19 specimens in seven samples from 602 to $984 \mathrm{~m}$. Also six specimens from two stations in the Faroe-Shetland channel, 1220 and 1338 $\mathrm{m}$, and five from two samples deeper than $2600 \mathrm{~m}$.

*Diaphana lactea (Jeffreys, 1877) - The lower slope and the abyssal basin (559 to $2500 \mathrm{~m}$ ) in the Norwegian Sea (Schiøtte 1998). According to Schiøtte, all records from depths less than $1200 \mathrm{~m}$ (altogether five records) are from the slope north and northwest of the Faroes. In my material one specimen from the lower slope, $1494 \mathrm{~m}\left(63^{\circ} 12^{\prime} \mathrm{N}\right)$ and an additional 23 specimens from five samples from deeper than $2000 \mathrm{~m}$.

Diaphana minuta Brown, 1827 - According to Schiøtte (1998) this species is found along the whole Norwegian coast in fairly shallow water (1 to c. 60 $\mathrm{m}$, but occasionally down to $100 \mathrm{~m}$ ) from the Swedish border and north to East Finnmark. Wikander (1989, 1990) reports 23 samples with a total of 38 specimens from the Skagerrak coast. Most of these are from fairly shallow water and may safely be accepted as D. minuta, but a few specimens dredged from depths between 100 and $155 \mathrm{~m}$ might actually belong to D. globosa. In my material 192 specimens and an additional 36 shells from the Espegrend area (145 specimens) north to Gratangen (68 $44^{\prime} \mathrm{N}, 90-80 \mathrm{~m}$, fine shell sand with lots of Modiolula phaseolina, two specimens).

Colobocephalus costellatus M. Sars, 1870 - This species is thoroughly discussed by Odhner (1939), based on material from Kopervik $\left(59^{\circ} 15^{\prime} \mathrm{N}\right)$, the only locality in addition to the type locality in Oslofjorden from which the species has been reported. In my material a single specimen from the shelf outside Korsfjorden $\left(60^{\circ} 08^{\prime} \mathrm{N}, 330-300 \mathrm{~m}\right.$, sand, shell sand and pebbles, coll. and leg. A. Warén).

Colpodaspis pusilla M. Sars, 1870 - Apparently only known from Oslofjorden so far. In my material a single specimen from Liholmsrennen $\left(60^{\circ} 18^{\prime} \mathrm{N}, 95-\right.$ $100 \mathrm{~m}$, stones and slag) may belong to this species.

Rhinodiaphana ventricosa (Jeffreys, 1865) - Redescribed by Lemche (1967) from a single specimen dredged in Fanafjorden, northern side $\left(60^{\circ} 14^{\prime} \mathrm{N}, 80 \mathrm{~m}\right.$, blackish mud). In Norway only known from two specimens from Lofoten (c. $68^{\circ} \mathrm{N}$ ) (G.O. Sars (1878) in addition to the specimen used for the redescription. Briefly discussed by Platts (1985) and van der Linden (1996, as 'Philine' cf. ventricosa). Not in my material. 
Toledonia limnaeoides (Odhner, 1913) - Illustrated and briefly discussed in Warén (1989), in which the depth distribution is given as $10-20 \mathrm{~m}$ (Spitsbergen) to $400 \mathrm{~m}$. Previously only reported from Spitsbergen, Greenland and northern Iceland. In my material five specimens of this rare cold water species from four slope stations with negative temperatures $\left(-0.9^{\circ} \mathrm{C}\right)$ just north of the Norwegian Trench (around 62 $30^{\circ}$ $\mathrm{N}, 701,708,781$, and $804 \mathrm{~m}$ respectively).

Retusa obtusa (Montagu, 1803) - According to Lemche (1948) R. pertenuis (Mighels, 1843) is a synonym (accepted by Thompson 1988 and ClEMAM). G.O. Sars (1878) and Odhner (1907) keep them apart, and judging from the geographical distributions given by these authors, this is a reasonable conclusion. While R. obtusa is described from southern England, and reported from Tromsø, the Baltic, British coasts and into the Mediterranean, $R$. pertenuis is an Arctic form, in Norway known from Vadsø, Hammerfest and Tromsø. See G.O. Sars (1878:349) for a discussion of conchological characters. According to Schiøtte (in litt.) R. obtusa is a species complex, and should be adressed as $R$. obtusa s.l. A preliminary revision by Chaban (2000) concludes that several species are involved, but the specific subdivision should be based on the male genitalia rather than conchological characters. Even as species complex, sometimes hard to separate from juvenile $R$. truncatula. Wikander (1990) reports two specimens from a station near Mandal (58 $\left.01^{\prime} \mathrm{N}, 13 \mathrm{~m}\right)$. In my material 33 shells and one specimen from four stations in Nordland south of Bodø, in addition to scattered specimens from the Andfjorden area. Twenty specimens from the Hillersholmen $\left(60^{\circ} 18^{\prime} \mathrm{N}\right)$ investigation are all juveniles, and might be misidentified $R$. truncatula, which were usually recorded in the same samples.

Retusa truncatula (Bruguière, 1792) - Apparently not previously reported from East Finnmark, as G.O. Sars (1878) gives western Finnmark as the northern limit, with a few additional finds in Lofoten. He mentions that it is very common on the west and south coast. Wikander $(1989,1990)$ reports 11 samples with a total of more than 130 specimens from Skagerrak. In my material 87 specimens and an additional 250 shells from the whole coastline covered, although only a few empty shells from the Andfjorden area and East Finnmark. The record from East Finnmark is from the inner part of Varangerfjorden, $\left(29^{\circ} 04^{\prime} \mathrm{E}\right.$, six m, mostly Laminaria saccharina on gravel and coarse sand), unfortunately not available for reexamination. More than 100 empty shells from Nordland south of Bodø.
Cylichnina umbilicata (Montagu, 1803) [= Retusa umbilicata] - Clemam and Hansson (1998) disagree on the status of $C$. nitidula (Lovén, 1846). While Clemam keeps the two as separate species, Hansson regards C. nitidula as a synonym of $C$. umbilicata. Smith \& Heppell (1991) as well as Sabelli et al. (1990, 1992) also regard $C$. nitidula as a variety of $C$. umbilicata, without comments. According to G.O. Sars (1878) the main difference should be a distinct spiral striation in C. umbilicata, lacking in C. nitidula, the latter being a more northern form. Here I follow the majority in regarding $C$. nitidula as a junior synonym, but should the two turn out to be specifically distinct, the bulk of my material probably should be called $C$. nitidula. This is one of the more common gastropods on soft bottoms in Norwegian waters, distributed from western Finnmark and southwards (G.O. Sars 1878). Wikander $(1989,1990)$ reports 59 samples with a total of more than 570 specimens from the Skagerrak coast. In my material at least 600 specimens and an additional 500 shells from the Espegrend area and north to Grovfjord ( $\left.68^{\circ} 41^{\prime} \mathrm{N}\right)$. The distribution has a distinct peak in the Møre og Romsdal series, with 550 specimens from 37 stations. In large series (e.g. 25 specimens from Silavågen, $66^{\circ} 19^{\prime} \mathrm{N}$ ) the variation in shell shape is extensive.

Pyrunculus ovatus (Jeffreys, 1871) [=Pyrunculus ovatus (Jeffreys, 1870)] - G.O. Sars (1878), who introduced this species to the Norwegian fauna, only found five shells in a sample from ca. $550 \mathrm{~m}$ (300 fathoms) in Lofoten. In my material one shell from each of two samples, from Bindalsfjorden ( $65^{\circ} 09^{\prime} \mathrm{N}, 180 \mathrm{~m}$, sand mixed with clay) and Risværfjorden ( $64^{\circ} 59.5^{\prime} \mathrm{N}, 200$ $\mathrm{m}$, coral rubble).

Volvulella acuminata (Bruguière, 1792) - According to Odhner (1939) previously found in Oslofjorden, Osterfjorden, near Molde and Trondheimsfjorden. In my material two samples with three specimens and five shells from Haramsfjorden, Møre og Romsdal ( $62^{\circ} 36^{\prime} \mathrm{N}$, c. $40-50 \mathrm{~m}$ sandy bottom). Also two shells from Namsenfjorden $\left(64^{\circ} 35^{\prime} \mathrm{N}, 60-11 \mathrm{~m}\right.$, clay with sand and gravel). In addition a single, live caught juvenile from $87 \mathrm{~m}, 58^{\circ} 30^{\prime} \mathrm{N}$ in the North Sea.

*Cylichnium africanum (Locard, 1897) - Abyssal (below $2900 \mathrm{~m}$ ) basin of the Norwegian Sea, north to $66^{\circ} 45^{\prime}$ N (Bouchet \& Warén 1979). Not in my material.

Johania cf. retifera (Forbes, 1844) - Two specimens, the largest c. $3.4 \mathrm{~mm}$ long, from a station in the Norwegian Trench ( $60^{\circ} 31^{\prime} \mathrm{N}, 300 \mathrm{~m}$, silt and clay) from the 1988/89 Fensfjorden investigation, original- 
ly identified to, and published as, Laona finmarchica. Closer examination revealed that this is a misidentification. The very characteristic microscopic shell sculpture does not resemble any published illustration of European species of the family except $J$. retifera, a Mediterranean species recently also reported by van der Linden (1995) from off Mauretania. The shape of the shell is also more similar to the illustration in van der Linden than any other illustrated species.

Laona finmarchica (M. Sars, 1858) [= Philine finmarchica] - According to G.O. Sars (1878) and Odhner (1907) found from Lofoten (uncommon) to East Finnmark, and scattered in negative temperatures on the upper slope south to $66^{\circ} 41^{\prime} \mathrm{N}, 640 \mathrm{~m}$. This is supposed to be the only species of Philine s.l. in addition to Philine lima and Philine quadrata living in Finnmark (Norman 1902). The latter two species have radically different habitus, and the three cannot be confused. In my material a sample of 15 specimens from inner Varangerfjorden $\left(70^{\circ} 04^{\prime} \mathrm{N}, 174 \mathrm{~m}\right.$, fine sand). In my material also plentiful from slope stations, 111 specimens from nine stations from 543 to $879 \mathrm{~m}$. In addition seven specimens from $1220 \mathrm{~m}$ in the Faroe-Shetland channel, and a single one from $2025 \mathrm{~m}$ in the central Norwegian Sea.

Laona flexuosa (M. Sars, 1870) [= Philine flexuosa - By many experts regarded as a synonym of $L$. pruinosa, but accepted by CLEMAM. Only reported from Oslofjorden and the eastern Skagerrak area (but listed in G.O. Sars 1878 from 'Ora occident. Norv.'). Not mentioned in Thompson (1988) or Platts (1985). In Smith \& Heppell (1991) listed as a questionable synonym of $P$. pruinosa. The differences between the two forms briefly described in G.O Sars (1878) under the discussion of $P$. pruinosa. G.O Sars also presents good illustrations of the radula-teeth of both forms. Discussed by Lemche (1948) who sees no reason for keeping them apart. Not in my material.

Laona pruinosa (W. Clark, 1827) [= Philine pruinosa - Reported from Lofoten and southwards to the Skagerrak coast, Oslofjorden and the Swedish west coast (Odhner 1907). In my material a single specimen from Breisunddjupet ( $\left.62^{\circ} 27^{\prime} \mathrm{N}, 245 \mathrm{~m}\right)$, clearly distinct from the common $P$. quadrata, seems to best fit the description in G.O. Sars (1878) and also the drawings in Lemche (1948), and Thompson (1988).

Philine angulata Jeffreys, 1867 - According to Odhner (1907), only a single record from Norway, from Ålesund, 18-55 m (from G. O Sars 1878). Recently reported from five stations around the Faroes by
Schiøtte (in Sneli et al. 2005). In my material a single shell from Haramsfjorden $\left(62^{\circ} 36.5^{\prime} \mathrm{N}, 42 \mathrm{~m}\right.$, sand) with much the same microsculpture as $P$. punctata, but much thinner, more transparent shell, no constriction near the apex, and an 'overhanging' upper, outer lip, seems to fit the illustrations of this species in van der Linden (1994). I have also assigned to this species two tiny specimens from Bjorøy in Raunefjorden $\left(60^{\circ} 18^{\prime} \mathrm{N}, 15-4 \mathrm{~m}\right.$, fine shell sand and mud), based on the little that is visible of the shell through the mantle. They are pure white and rather oblong, and direct comparison with $P$. scabra of the same size excludes any confusion with that species.

Philine aperta (Linné, 1767) - The distribution in Norwegian waters of this large (for the genus) species has been summarised by Odhner (1939) who confirmed the identity of specimens from 13 localities along the coast of Mid-Norway (from $62^{\circ}$ to $67^{\circ}$ $\mathrm{N})$. The northernmost record is from Fleinvær just southwest of Bodø (67 10' N). Earlier Grieg (1914) reported it as being fairly common from $10-50 \mathrm{~m}$ in Hardangerfjorden. Wikander $(1989,1990)$ found more than 500 specimens (in addition to more than 1000 he regarded as doubtful) at no less then 46 localities in his investigations along the Skagerrak coast. In my material a single, tiny, dried up juvenile and an egg string supposedly belong to this species. Two other samples with four species each not refound for verification. Probably an uncommon species on the coast north of Korsfjorden.

Philine catena (Montagu, 1803) - According to G.O. Sars (1878) and Odhner (1907) to be found along the whole Norwegian coast north to Lofoten. In my material a shell from Breisunddjupet $\left(62^{\circ} 28^{\prime} \mathrm{N}, 120-60 \mathrm{~m}\right.$, shell sand) best fits the illustrations in van der Linden (1994). Another one fitting this illustration is one of two shells from the deepest part of Korsfjorden, at $680 \mathrm{~m}$.

Philine denticulata (J. Adams, 1800) - Horikoshi (1967) redescribed and illustrated this species, based on material from Øresund. According to G.O. Sars (1878) and Odhner (1907) previously only recorded from shallow water near Tromsø and in Kjosen in Ullsfjorden (around $69^{\circ} 35^{\prime} \mathrm{N}$ ). In my material five samples from Møre og Romsdal, between $62^{\circ} 10^{\prime}$ to $63^{\circ} 10^{\prime} \mathrm{N}$, contained a total of 26 specimens. With a single exception all these samples were from 40 to $60 \mathrm{~m}$ with substrate classified as sand. In addition a large sample of at least 50 specimens from a little bay in Sjona, 66 $19^{\prime} \mathrm{N}, 18-20 \mathrm{~m}$, soft bottom. 
Philine infortunata Pilsbry, 1895 - One of the more problematic species of the family. Described by G.O. Sars (1878) from a single shell from Lofoten, 45-75 $\mathrm{m}$, as Philine vitrea M. Sars, a name that was found to be preoccupied and replaced by $P$. infortunata. Discussed by Lemche (1948) and briefly by Platts (1985), Smith \& Heppel (1991) and van der Linden (1995). Lemche concludes that the identity of the material from Oslofjorden found and described by $\mathrm{M}$. Sars cannot be safely assumed to be the same species as the shell from Lofoten, found and described by G.O. Sars. Schiøtte (1998) agreed and finally settled the matter by selecting one of the shells which M. Sars had included in his Bulla (=Utriculopsis) vitrea , as neotype of this latter. This specimen Schiøtte found to be a typical Diaphana hiemalis, and Utriculopsis vitrea thus is a junior synonym of $D$. hiemalis. $P$. infortunata is thus so far only known from a single shell from Lofoten. Not in my material.

Philine lima (Brown, 1827) - According to Odhner (1907) found in northern Norway from Kjosen in Ullsfjord $\left(69^{\circ} 35^{\prime} \mathrm{N}\right)$ to East Finnmark, and also on the slope at c. $63^{\circ} \mathrm{N}, 730 \mathrm{~m}$. In my material a single specimen from Toppsund ( $68^{\circ} 54^{\prime} \mathrm{N}, 150-170 \mathrm{~m}$, mud and fine sand), originally classified as $P$. quadrata has a habitus diverging from typical specimens of this species. The size of the shell is around 6-7 mm, its length is greater compared to the width than is the case for $P$. quadrata, but it is not nearly as slender as typical $P$. scabra. The way the ethanol-preserved animal is contracted is radically different from both $P$. scabra and P. quadrata. However the external soft parts are too disturbed for the external habitus of a living animal to be recognized, while they cover the shell enough for the diagnostic characters to be hidden from view. The identification to $P$. lima is definitely tentative. Another specimen which is definitely this species is one from the slope, at $604 \mathrm{~m}\left(62^{\circ} 30^{\prime} \mathrm{N}\right)$.

Philine punctata (J. Adams, 1800) - Previously recorded from Florø $\left(61^{\circ} 35^{\prime} \mathrm{N}\right)$ to Oslofjorden (Odhner 1907). Based on the densely spotted, rather dark coloured (olive gray) soft parts, a number of specimens have been classified as this species. In my material a single specimen from Nordland south of Bodø and a small sample from Haramsfjorden $\left(62^{\circ} 36.5^{\prime} \mathrm{N}\right.$, $42 \mathrm{~m}$, sand). The latter consists of two shells and three juveniles. The mantle does not cover the shell completely in any of the three. A single very small (1.2 $\mathrm{mm}$ long) specimen from Hillersholmen $\left(60^{\circ} 18^{\prime}\right.$ $\mathrm{N}, 6-8 \mathrm{~m}$ ) has also been assigned here for lack of a better alternative, but the shell is completely covered, and the determination thus cannot be verified from shell shape or sculpture. A sample from Ospøy in Raunefjorden $\left(60^{\circ} 15^{\prime} \mathrm{N}, 27-10 \mathrm{~m}\right.$, coarse shell gravel) contained seven newly settled juveniles. The spotted colour pattern is just starting to show on the few largest of the lot. A shell from Breisunddjupet $\left(62^{\circ} 28^{\prime} \mathrm{N}, 120-60 \mathrm{~m}\right.$, shell sand) seems to best fit this species (based on van der Linden 1994) as well as a nearly identical looking shell from Sjonafjorden (66 $16^{\circ} \mathrm{N}, 160-80 \mathrm{~m}$, gravel). Also a small juvenile from Vefsnfjorden $\left(65^{\circ} 53^{\prime} \mathrm{N}, 15-12 \mathrm{~m}\right.$, red algae on rocky bottom) in which the shell is not covered by the mantle has a shell microsculpture very similar to P. punctata.

Philine quadrata (S. Wood, 1839) - According to G.O. Sars (1878) common along the entire coast in depths below c. $40 \mathrm{~m}$. Odhner (1939) lists it in addition to P. aperta and P. scabra from a number of localities in mid and north Norway. Wikander $(1989,1990)$ reports a total of seven samples with one specimen each from the Skagerrak coast, many of which he regarded as doubtful identifications. In my material not quite as common as $P$. scabra. Only four samples recorded from the Espegrend area. Two samples from East Finnmark, seven from Nordland south of Bodø and 11 from Møre og Romsdal. In my material also three specimens from the slope, one from 543 $\mathrm{m}$, one from $604 \mathrm{~m}$ and one from $701 \mathrm{~m}$ just north of the Norwegian Trench. Of four specimens from Vevelstadsundet $\left(65^{\circ} 42.5^{\prime} \mathrm{N}, 65-45 \mathrm{~m}\right.$, sand and shell gravel), one is divergent in having the buffcoloured (in ethanol) body filled with numerous and large white glandular(?) globules. The habitus is in other aspects close to 'typical' $P$. quadrata. Three specimens from Lille Sjona $\left(66^{\circ} 12^{\prime} \mathrm{N}, 70-64 \mathrm{~m}\right.$, soft bottom) might belong to two species, as the soft parts of two of the specimens are yellowish with whitish granules or reticulation inside. The same is the case for a sample from Aldersundet $\left(66^{\circ} 27^{\prime} \mathrm{N}\right.$, 110-100 m, foraminiferous substrate), in which three are juveniles, while the fourth is somewhat larger, yellowish-beige with white globules. The fairly rich material from the 1988/89 Fensfjord investigation, has, with the exception of the specimens of Johania cf. retifera mentioned above, for convenience been divided into $P$. quadrata and $P$. scabra. However, two samples from Sognesjøen $\left(61^{\circ} \mathrm{N}, 470 \mathrm{~m}\right.$, clay and silt), containing respectively nine and 11 small specimens, most certainly belong to another species. The microsculpture visible through the mantle is of the common catenoid kind, but except for that no details visible (no shells for comparison). The soft part visible through the shell is reddish brown, with a large black dot seen dorsally. 
Philine scabra (O.F. Müller, 1784) [= Philine scabra Müller, 1776] - CLEMAM cite 1784 as year of publication although most other sources cite 1776 . This basically southern species is, together with $P$. quadrata presumably the commonest species of the genus in Norwegian waters. According to G.O. Sars (1878) common from western Finnmark and southwards below c. $20 \mathrm{~m}$. Also included by Odhner (1939) from Trondheimsfjorden as one of only two species. Wikander $(1989,1990)$ reports 96 samples with a total of more than 1000 specimens from the Skagerrak coast. My northernmost record is from Grovfjord at $68^{\circ} 40^{\prime} \mathrm{N}$. The large majority of my material is from Møre og Romsdal, with altogether 15 samples. Seven samples from Nordland south of Bodø also contain specimens identified as P. scabra. Only a very few specimens from the Espegrend area. Two shells from Stura in Hjeltefjorden $\left(60^{\circ} 36.5^{\prime} \mathrm{N}\right.$, 80-50 m, silt and clay) have a coarser sculpture and are wider than typical $P$. scabra. In my slope material three specimens from $543 \mathrm{~m}$ at $62^{\circ} 20^{\prime} \mathrm{N}$. Some very well preserved specimens from Aursundet ( $63^{\circ} 14.5^{\prime}$ $\mathrm{N}, 140-120 \mathrm{~m}$, soft bottom, fine sand), have a distinct furrow, and should thus according to G.O. Sars (1878) belong to $P$. loveni Malm, 1855. This latter species is generally regarded as a synonym of $P$. scabra, a conclusion accepted by CLEMAM.

Cylichna alba (Brown, 1827) - Schiøtte (in litt.) recommends the use of $C$. alba s.l. for this taxon as probably more than one species is present within our area. Common all along the coast, although somewhat less common in Finnmark (G.O. Sars 1878). Not mentioned in Wikander $(1989,1990)$. In my material shells and specimens from eight samples from East Finnmark, nine from the Andfjorden area, 16 from Nordland south of Bodø, 12 from Nord-Trøndelag and finally 12 from Møre og Romsdal (highest abundance of shells, 38 from Breisund-djupet, $62^{\circ} 28^{\prime} \mathrm{N}$ ), only 17 specimens caught alive. Most samples from 150-250 m. In comparison rather few samples from Espegrend/Herdla, most of them from Herdla. A series of 12 specimens from the Norwegian Trench from the 1988/89 Fensfjord investigation, (300-370 $\mathrm{m})$, shows the variability and ontogenetic changes of this variable species. The juveniles have a transparent shell, with a distinctly grayish colour from the soft parts seen through the shell, while the adults have an opaque shell with a yellowish to white periostracum.

Cylichna cylindracea (Pennant, 1777) - Previously reported from Lofoten and southwards but everywhere distinctly less common than C. alba (G.O. Sars 1878). Wikander $(1989,1990)$ disagrees, and reports
65 samples with a total of more than 750 specimens from the Skagerrak coast. Most of these from fairly shallow water (20 to $50 \mathrm{~m}$ ). In my material a single shell from Gratangen ( $68^{\circ} 44^{\prime}$ N, 70 m, rocky bottom) which may represent a new northern distributional limit for the species. Otherwise sparingly from several stations from Møre og Romsdal shells and a very few samples from the Espegrend area, no specimens caught alive. Obviously much more common on the Skagerrak coast than further north.

Cylichna lemchei Bouchet \& Warén, 1979 - Previously recorded from between 2400 and $2700 \mathrm{~m}$ in the deep basin of the Norwegian Sea (Bouchet \& Warén 1979). In my material scattered records from the slope and into the abyssal zone, from 543 to $2304 \mathrm{~m}$. Not all of these are certain, however, especially the shallowest ones may be doubtful.

Cylichna occulta (Mighels \& Adams, 1842) - Previously reported from East Finnmark south to Tromsø and Kjosen in Ullsfjorden (69 $35^{\circ}$ N) (G.O. Sars 1878, Friele \& Grieg 1901 and Odhner 1907). In my material a single sample from East Finnmark (Neidenfjorden, $69^{\circ} 43^{\prime} \mathrm{N}, 66 \mathrm{~m}$, muddy bottom, four specimens and two shells).

Roxania utriculus (Brocchi, 1814) - This southern species has been reported north to $65^{\circ} 30^{\prime} \mathrm{N}$ (G.O. Sars 1878, Friele \& Grieg 1901). Wikander (1990) reports a single specimen from $46 \mathrm{~m}$ just south of Grimstad $\left(58^{\circ} 18^{\prime} \mathrm{N}, 8^{\circ} 33^{\prime} \mathrm{E}\right)$. In my material it was found only sparingly. A single specimen from Ellingsøyfjorden $\left(62^{\circ} 29^{\prime} \mathrm{N}, 52-44 \mathrm{~m}\right.$, sand), and one shell from Namsenfjorden $\left(64^{\circ} 35^{\prime} \mathrm{N}, 60-11 \mathrm{~m}\right.$, clay mixed w/sand and gravel). Further two shells from Gurskøy $\left(62^{\circ} 18^{\prime} \mathrm{N}, 35-30 \mathrm{~m}\right.$, sand, gravel and stones and many large bivalve shells) and one from Frenefjorden $\left(62^{\circ} 50^{\prime} \mathrm{N}, 62-50 \mathrm{~m}\right.$, sand). Also a juvenile from the outer part of Masfjorden ( $290 \mathrm{~m}$, silt and clay) from the 1988/89 Fensfjord investigation.

Scaphander spp. - The main difference between fully developed $S$. lignarius and $S$. punctostriatus is the shape of the shell. An evenly rounded shell with an open outer lip extending appreciably beyond the intorted, pin-point apex for S. punctostriatus. A shell narrowing towards the apex with a flattish, white-rimmed somewhat more open apex with a less extending outer lip for $S$. lignarius. In addition it appears that the soft parts are more voluminous and less retractable in S. lignarius. The periostracum is yellowish, sometimes with a golden brown tint (and reddish brown flames), and with the spiral sculpture 
highlighted by a clearly darker brown colour in $S$. lignarius. In large shells of $S$. punctostriatus, the spiral sculpture is more or less covered (and thus obscured) by the periostracum. These characters are getting gradually less reliable for smaller individuals and juveniles (see below).

Scaphander lignarius (Linné, 1758) -This is a southern species, according to G.O. Sars (1878) found from Lofoten southwards. Odhner (1939) cites a record from Tromsøysund ( $\left.69^{\circ} 40^{\prime} \mathrm{N}, 125 \mathrm{~m}\right)$ and Brattegard (in Høisæter et al. 1997b) reports it from his section 22 (western Finnmark) which has a southern limit at c. $70^{\circ} \mathrm{N}$. Not mentioned in Wikander $(1989,1990)$ from Skagerrak. In my material the northernmost record is from Saltfjorden SW of Bodø $\left(67^{\circ} 15^{\prime} \mathrm{N}\right.$, shell gravel and small stones dredged from some 50 to $13 \mathrm{~m}$ ). Usually found at intermediate depths, with mixed bottoms. Juveniles from the stations just south of Bodø have characters intermediate between S. lignarius and $S$. punctostriatus, but as the many adults from these stations are all 'typical' S. lignarius, I assume that all belong to this species. In the series from Møre og Romsdal S. lignarius dominated over S. punctostriatus, with nine samples containing 35 specimens and some 45 shells. Although presumably common in the Espegrend area, only a single sample containing seven specimens from Fanafjorden $\left(60^{\circ}\right.$ $14^{\prime} \mathrm{N}, 145-163 \mathrm{~m}$, soft bottom) have been preserved. A single juvenile in a sample containing also 16 juvenile S. punctostriatus from the 1988/89 Fensfjord investigation, resembles closely equally large juveniles of S. lignarius from off Kristiansund ( $63^{\circ} 10^{\prime}$ $\mathrm{N}, 145 \mathrm{~m}$, sand).

Scaphander punctostriatus (Mighels \& Adams, 1842) - This species has a northern distribution and is adapted to soft bottoms in deep waters. In the southern part of its distribution it is found exclusively in fairly deep waters (below around $300 \mathrm{~m}$ ). Previously reported from the whole coast (G.O. Sars 1878), but not found by Wikander $(1989,1990)$ on the Skagerrak coast. Large shells are easily recognized on their glossy, dark brown periostracum. Shells of juveniles are white (or 'colourless', transparent) and I find them sometimes difficult to distinguish from equally large S. lignarius. The most reliable difference (in addition to the shape of the gizzard plates) seems to be connected to the spiral sculpture. While $S$. lignarius has continuous depressed spiral lines with small and narrow, oblong pits at their bottoms, S. punctostriatus has isolated almost circular indentations, much like the scultpture of Philine punctata or P. angulata as illustrated in van der Linden (1994). S. punctostriatus is also much narrower than equally long S. lignarius, caused by a more rapidly broadening of the aperture. Apparently the periostracum is developing later in $S$. punctostriatus than in S. lignarius.

In my material a sample from Jarfjorden by Skipshamnsholmen $\left(69^{\circ} 47^{\prime} \mathrm{N}, 215 \mathrm{~m}\right.$, mud w/lots of chitinous polychaete tubes) contained two specimens and 10 large shells of this species. Four samples contain juvenile Scaphander from the Andfjorden series and all are provisionally assigned to $S$. punctostriatus. The largest are two, somewhat aberrant, specimens, $11.5 \mathrm{~mm}$ (shell) and $10 \mathrm{~mm}$ (live caught) from the rich station in Gratangen $\left(68^{\circ} 44^{\prime} \mathrm{N}\right)$. I could see no trace of any periostracum. Thick shell that looked like it had grown in two stages, quite symmetrical in first half, and rather irregular growth in the later stage. Both shells with a distinct callus on inner lip. A third specimen around $2.5 \mathrm{~mm}$ long was apparently quite normal. The locality is atypical for this species, 90-80 m, fine shell sand with much Modiolula phaseolina. The other locality, with three samples, from outer Grovfjord ( $68^{\circ} 40.5^{\prime} \mathrm{N}, 200$ and $300 \mathrm{~m}$, soft bottom). The specimens were all normal looking juveniles. I also have four samples from Nordland south of Bodø, all juveniles, with an especially nice sample of 15 specimens from outer Velfjorden ( $65^{\circ} 31^{\prime} \mathrm{N}, 405-400 \mathrm{~m}$, soft bottom). In the series from Møre og Romsdal S. punctostriatus was found in only four samples, three specimens and nine shells, all of them juveniles. Surprisingly few records from the Espegrend area, only two shells kept, one of them (in poor condition) from Raunefjorden, outside Skogsvåg (6 September 1958, leg. H. Tambs-Lyche), the other from Korsfjorden $\left(60^{\circ} 12^{\prime} \mathrm{N}, 680 \mathrm{~m}\right.$, soft bottom). In addition a number of juveniles from the outer stations (offshore and outer fjord) from the 1988/89 Fensfjord investigation.

Aplysia punctata Cuvier, 1803 - A common species on algae in shallow water north to at least $64^{\circ} \mathrm{N}$. According to Moen (in Moen \& Svensen 2003) also found scattered in western Finnmark. Wikander (1989) reports a single specimen from the archipelago just south of Arendal $\left(58^{\circ} 25^{\prime} \mathrm{N}\right)$. Two juveniles from two samples in Raunefjorden, 15 and $83 \mathrm{~m}$ respectively, 25 October 2007. Otherwise found regularly but not preserved, in the Espegrend area.

Akera bullata O.F. Müller, 1776 - According to G.O. Sars (1878) found sparingly in Øksfjord in western Finnmark and in Lofoten, but abundant on the west and south coast. Friele (1903) reported a specimen from the littoral zone in Porsangerfjorden, around $25^{\circ} 20^{\prime} \mathrm{E}$, and Soot-Ryen (1951) extended the distri- 
bution to East Finnmark. Wikander (1990) reports five samples with a total of 12 specimens from the Skagerrak coast. In my material a single sample with four specimens from Kvernapollen in O-sundet $\left(60^{\circ}\right.$ $33^{\prime} \mathrm{N}, 12-2 \mathrm{~m}$, coarse shell sand mixed with very soft mud and loose algae) but not particularly rare in shallow, sheltered localities in the Espegrend area.

\section{DISCUSSION}

This compilation is by no means complete, as many parts of the coast have so far been neglected, and many minute species might still be discovered if the right methods are deployed. An example is the methane seeps on the slope outside mid Norway (Nyegga and Storegga, around $63^{\circ}$ to $63.5^{\circ} \mathrm{N}$ ) where representatives of common cold seep genera like Hyalogyrina and Xylodiscula recently have been identified by Anders Warén (in litt.).

Altogether 365 species of shell bearing gastropods have been included in this report (the corresponding number in Høisæter (1986) was 323 species), of which 326 species are confirmed to belong to the Norwegian fauna within the distributional limits defined here. The rest are for various reasons regarded as doubtful, and marked with an asterisk $(*)$ in the main text and the systematic synopsis. Of the 365 species, I have personally looked at material of 311, 54 species are thus included from literature records only.

Some of the 40 questionable species (See Table 2) are: nine species described from depths below $2000 \mathrm{~m}$ in the Norwegian Sea (or elsewhere), but also recorded on the slope somewhere around the Nordic Sea basin at depths approaching $1200 \mathrm{~m}$ : Anatoma cf. umbilicata, Skenea profunda, S. turgida, Anekes undulisculpta, Pseudosetia semipellucida, Mohnia danielsseni, Oenopota ovalis, Diaphana lactea, Cylichnium africanum.

Seven species known from the North Sea or English Channel, and recorded or suggested to live in Norwegian waters, but later retracted or never confirmed: Similiphora similior, Ceratia proxima, Bela costulata, Haedropleura septangularis, Rissoella opalina, Odostomia plicata, Turbonilla lactea.

Three arctic species whose reports from Norwegian waters are most likely due to a mixup of museum labels: Scabrotrophon fabricii, Buccinum scalariforme, Aartsenia candida.

At least nine species so far only known from Norwegian waters as empty shells: Manzonia crassa, Elachisina globuloides, Circulus sarsi, Chrysallida bjoernssoni, Chrysallida sarsi, Chrysallida truncatula, Ondina coarctata, and Rissopsetia islandica .
One brackish water species reported from Iddefjorden but never refound: Theodoxus fluviatilis.

And finally Ondina perezi whose taxonomic status is disputed. This latter category could easily be expanded to include tens of further species if all names from some of the most confusing groups had been included. Thus in Eulimidae, Rissoidae, Buccinum, and especially Oenopota many species names have been accepted as synonyms although much work still remain before the status of these are finally settled.

Of the species here recognized as belonging to the Norwegian benthic fauna, at least 18 are so far undescribed (the genus 'Vitreolina' may turn out to contain several, perhaps as many as five or six undescribed species); these are provisionally placed in the genera, Iothia, Anatoma, Skenea, Eumetula, Eulima, Vitreolina, Alvania, Trichotropis, Euspira, Admete, Raphitoma, Eulimella, Odostomia, and Tjaernoeia.

Of the species included, 16 have been described since 1985 (not including those that have only received a new name): Lissotesta turrita, Palazzia ausonia, Trochaclis islandica, Melanella turrita, Alvania incognita, Onoba improcera, Xylodiscula planata, Chrysallida bjoernssoni, Chrysallida brattstroemi, Chrysallida hoeisaeteri, Eulimella ataktos, Liostomia afzelii, Liostomia hansgei, Rissopsetia islandica, Cima cuticulata, Cima inconspicua.

A further 23 have been added to (or confirmed from) the Norwegian fauna in this period: Anatoma aspera, Eudaronia aperta, Krachia cossmanni, Halielloides nitidus, Melanella orphanensis, Alvania incognita, Alvania moerchi, Boreocingula castanea, Onoba islandica, Buccinum oblitum, Mohnia glypta, Bela powisiana, Raphitoma aequalis, Chrysallida nivosa, Odostomia cf. angusta, Odostomia striolata, Ondina obliqua, Turbonilla cf. pusilla, Turbonilla rufa, Bacteridium cf. carinatum, Tjaernoeia exquisita, Toledonia limnaeoides, Johania $\mathrm{cf}$. retifera.

The dominating systematic groups (based on the system used in Clemam) are: Pyramidelloidea with (at least) 48 species, Rissooidea with 38, Buccinoidea with 33, Conoidea and Cephalaspidea both with 32, and Eulimoidea with at least 20. All other super-families are represented in Norwegian waters with less than 20 species.

Based on my material I have been able to expand the distribution along the Norwegian coastline for a number of species, compared to the limits given in Høisæter (1986) and in newer reliable published sources (only occasionally including the otherwise useful compilation by Brattegard, in Høisæter et al. 1997). Thus 47 species have been assigned a new northern distributional limit, while 13 species have been assigned a new southern limit, many of the latter are from the slope. These 
extensions are of course not in any way to be interpreted as 'real' expansions, as they, except for a few large and conspicuous species, just reflect the fragmentary knowledge of the gastropod fauna on most parts of the coast.

A few biogeographical fauna elements are evident. Thus 14 species may be regarded as purely Arctic, in Norway only recorded from East Finnmark and sometimes also in negative temperatures on the slope further south: Solariella varicosa, Alvania scrobiculata, Boreocingula castanea, Frigidoalvania janmayeni, Obtusella tumidula, Pseudopolinices nanus, Buccinum tumidulum, Colus verkruezeni, Turrisipho lachesis, Turrisipho voeringi, Turritellopsis stimpsoni, Liostomia eburnea, Toledonia limnaeoides and Cylichna occulta.

Another conspicuous faunistic element consists of 16 species, in Norwegian waters mostly found in negative temperatures (or in the transition zone between negative and positive temperature) on the slope below 500-600 m (a few of these are listed also as 'Arctic' species): Skenea aff. proxima, Skenea n.sp. A, Eumetula n.sp., Melanella laurae, Alvania incognita, Alvania moerchi, Alvania aff. moerchi, Alvania pseudosyngenes, Alvania verrilli, Alvania wyvillethomsoni, Obtusella tumidula, Onoba islandica, Piliscus radiatus, Buccinum kjennerudae, Buccinum nivale, Buccinum oblitum, Colus turgidulus, Mohnia glypta, Turrisipho lachesis, Turrisipho voeringi, Admete contabulata, Admete n.sp., Iphinopsis inflata, Pleurotomella packardi, Chrysallida sublustris, Cima cf. cuticulata, and Toledonia limnaeoides. Only a single species of pyramidellids, the by far most species rich superfamily, is found in negative temperatures.

In addition there are four 'abyssal' species, with their main distribution below $2000 \mathrm{~m}$ in the Norwegian Sea, but with confirmed records from the slope above $1200 \mathrm{~m}$ : Retigyra millipunctata, Crinolamia dahli, Cryptonatica bathybii, and Mohnia mohni.

At the other end of the spectrum are 14 species that appear to be restricted to or having their main distribution on the Skagerrak coast: Aclis ascaris, Aclis minor, Epitonium clathratulum, Hyala vitrea, Crepidula fornicata, Erato voluta, Nassarius pygmaeus, Bela brachystoma, Bela nebula, Bela powisiana, Odostomia conspicua, Turbonilla cf. pusilla, Turbonilla rufa, and Cylichna cylindracea. Many of these are rather common in the North Sea, others are also found on the west coast north to the mouth of Hardangerfjorden, in Oslofjorden and on the Swedish west coast, but are much more common on the Norwegian Skagerrak coast.

Other faunistic elements might be listed here, e.g. species only found in shallow water or the intertidal on the outer coast of western Norway (two examples are Patella uslyssiponensis and Melarhaphe neritoides), or species with their distribution confined to intermediate depths $(10-100 \mathrm{~m})$ from $64^{\circ}$ to $68^{\circ} \mathrm{N}$

\section{(e.g. Moelleria costulata and Skenea areolata).}

As far as I know only one species, Crepidula fornicata, does not belong to the indigeneous Norwegian fauna. This originally Northwest-Atlantic species was first recorded from Norway in the late 1950-ties to early 1960-ties and has gradually spread along the Skagerrak coast and northward on the southwest coast to its present northern limit at around $59^{\circ} 05^{\prime}$ N. Potamopyrgus antipodarum is another introduced species, but as this is a freshwater species only occasionally found in brackish water on the southern coast, it is not discussed further.

\section{ACKNOWLEDGEMENT}

Several people should be mentioned, but especially Lotte Bonsel from the University of Utrecht, the Netherlands, who spent 5 months at the Institute of Biology in 2005 as 'internship trainee', has been indispensable for getting the last portions of the accumulated material from the summer cruises sorted and identified. Per Bie Wikander in Grimstad has been helpful both in sending me extremely valuable material of critical groups collected during his stay in Bodø and Grimstad, and in sharing his extensive knowledge of the mollusk fauna on the Norwegian Skagerrak coast and its fluctuations during the last 30-40 years. The comments of Tom Schiøtte on some of the cephalaspids, among other things pointing out a serious oversight on my part, are also highly appreciated. Taxonomic discussions with Anders Warén in Stockholm has helped me to avoid some potentially humiliating mistakes, and sharpened my acuity in distinguishing what might be specific differences between sibling species. His comments as a referee are also highly appreciated. The meticulous work of a second referee has been a great help to me. 
Table 2. Summary of distribution, taxonomic status and nomenclatural changes since the publication of Høisæter (1986), for all included species. "New to Norway" - Not recorded from Norwegian waters in earlier publications. "New N (or S)-limit" - New distributional limit based on my material. "Abyssal species" - Only known from depths below 2000 m. "Slope species" - Species exclusively or almost exclusively known from the slope between c. 500 and 2000 m. "Arctic species" - In Norway only known from East Finnmark or possibly also in Porsangerfjorden. "Skagerrak" - From the mouth of Oslofjorden to around Egersund (58 39' N). "West Norway " - north to $63^{\circ}$ $\mathrm{N}$ (around Kristiansund). "Mid Norway" - North to $65^{\circ} \mathrm{N}$ (Bindalsfjorden). "Not seen" - Included solely on the basis of literature data. "Not in Høisæter 1986" - Not mentioned in Høisæter (1986). "Descr. since 1985" - Described since the publication of Høisæter (1986). "Name ch. since 1986" - Either the genus, the species name or both changed from the ones used in Høisæter (1986)

\begin{tabular}{|c|c|c|c|c|c|c|c|c|c|c|c|c|c|c|c|c|c|c|}
\hline & 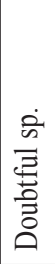 & 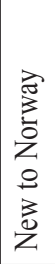 & 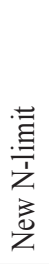 & 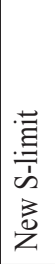 & 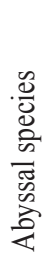 & 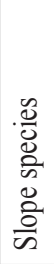 & 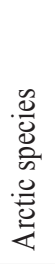 & 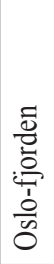 & 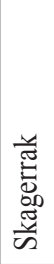 & 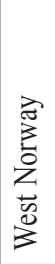 & 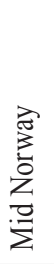 & 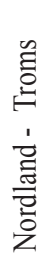 & 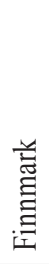 & 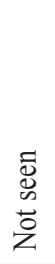 & 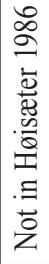 & 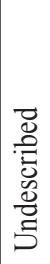 & 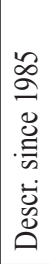 & 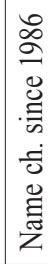 \\
\hline Patella ulyssiponensis (Gmelin, 1791) & & & & & & & & & & $*$ & & & & & & & & $*$ \\
\hline Patella vulgata Linné, 1758 & & & & & & & & * & $*$ & $*$ & $*$ & $*$ & $*$ & & & & & \\
\hline Ansates pellucida (Linné, 1758) & & & & & & & & $*$ & $*$ & $*$ & $*$ & & $*$ & & & & & \\
\hline Erginus rubellus (O. Fabricius, 1780) & & & & & & & & & & & & $*$ & $*$ & $*$ & & & & $*$ \\
\hline Tectura testudinalis (O.F. Müller, 1776) & & & & & & & & * & $*$ & $*$ & $*$ & $*$ & $*$ & & & & & $*$ \\
\hline Tectura virginea (O.F. Müller, 1776) & & & & & & & & $*$ & $*$ & $*$ & $*$ & $*$ & $*$ & & & & & $*$ \\
\hline Lepeta caeca (O.F. Müller, 1776) & & & & & & & & $*$ & $*$ & $*$ & $*$ & $*$ & $*$ & & & & & \\
\hline Iothia fulva (O.F. Müller, 1776) & & & & & & & & $*$ & $*$ & $*$ & $*$ & $*$ & $*$ & & & & & \\
\hline Iothia cf. fulva & $*$ & & & & & & & & & $*$ & & & & & & $*$ & & \\
\hline $\begin{array}{l}\text { Propilidium exiguum } \\
\text { (W. Thompson, 1844) }\end{array}$ & & & & & & & & * & & $*$ & $*$ & $*$ & & & & & & \\
\hline Emarginula crassa J. Sowerby, 1813 & & & & & & & & $*$ & & $*$ & $*$ & $*$ & & & & & & \\
\hline Emarginula fissura (Linné, 1758) & & & & & & & & * & $*$ & $*$ & $*$ & $*$ & $*$ & & & & & \\
\hline Puncturella noachina (Linné, 1771) & & & & & & & & $*$ & $*$ & $*$ & $*$ & $*$ & $*$ & & & & & \\
\hline Fissurisepta granulosa Jeffreys, 1883 & & & $*$ & & & & & * & & $*$ & * & & & & & & & \\
\hline Anatoma aspera (Philippi, 1844) & & $*$ & & & & & & & & $*$ & $*$ & & & & $*$ & & & \\
\hline Anatoma crispata (Fleming, 1828) & & & & & & & & * & $*$ & $*$ & $*$ & $*$ & $*$ & & & & & \\
\hline Anatoma n. sp. & & & & & & & & * & & $*$ & $*$ & $*$ & & & & $*$ & & \\
\hline Anatoma cf. umbilicata (Jeffreys, 1883) & $*$ & & & & $*$ & & & & & & & & & & $*$ & & & \\
\hline $\begin{array}{l}\text { Lepetella laterocompressa } \\
\text { (de Rayneval \& Ponzi, 1854) }\end{array}$ & & & $*$ & & & & & & & $*$ & $*$ & & & & & & & \\
\hline Clelandella miliaris (Brocchi, 1814) & & & $*$ & & & & & $*$ & * & $*$ & $*$ & $*$ & & & & & & $*$ \\
\hline Gibbula cineraria (Linné, 1758) & & & & & & & & * & $*$ & $*$ & $*$ & $*$ & $*$ & & & & & \\
\hline Gibbula tumida (Montagu, 1803) & & & & & & & & $*$ & $*$ & $*$ & $*$ & $*$ & $*$ & & & & & \\
\hline Margarites costalis (Gould, 1841) & & & & & & & & $*$ & & $*$ & $*$ & $*$ & $*$ & & & & & \\
\hline Margarites striata (Leach, 1819) & & & & & & & & & $*$ & $*$ & $*$ & $*$ & * & & & & & \\
\hline Margarites helicina (Phipps, 1774) & & & & & & & & $*$ & $*$ & $*$ & $*$ & $*$ & $*$ & & & & & \\
\hline Margarites olivacea (Brown, 1827) & & & & & & & & & & & & $*$ & $*$ & & & & & \\
\hline Solariella amabilis (Jeffreys, 1865) & & & & & & & & & & $*$ & $*$ & $*$ & & & & & & $*$ \\
\hline Solariella obscura (Couthoy, 1838) & & & $*$ & & & & & & & & $*$ & $*$ & $*$ & & & & & \\
\hline $\begin{array}{l}\text { Solariella varicosa } \\
\text { (Mighels \& Adams, 1842) }\end{array}$ & & & & & & & $*$ & & & & & & $*$ & & & & & \\
\hline
\end{tabular}


Table 2. Continued.

\begin{tabular}{|c|c|c|c|c|c|c|c|c|c|c|c|c|c|c|c|c|c|c|}
\hline & 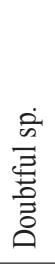 & $\begin{array}{l}z \\
0 \\
0 \\
0 \\
z \\
0 \\
0 \\
0 \\
0 \\
z\end{array}$ & 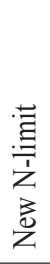 & $\begin{array}{l}\text { 离 } \\
\text { 竞 } \\
\text { 岂 } \\
\text { z }\end{array}$ & 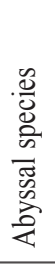 & 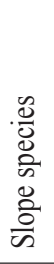 & 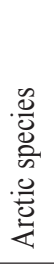 & 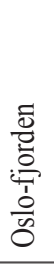 & 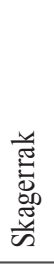 & 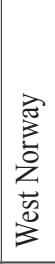 & 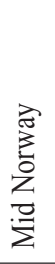 & 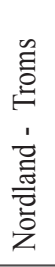 & 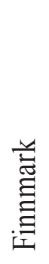 & 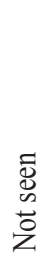 & 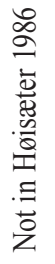 & 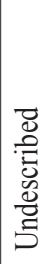 & 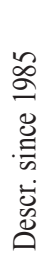 & 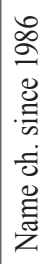 \\
\hline $\begin{array}{l}\text { Calliostoma occidentale } \\
\text { (Mighels \& Adams, 1842) }\end{array}$ & & & $*$ & & & & & & $*$ & $*$ & $*$ & $*$ & $*$ & & & & & $*$ \\
\hline Calliostoma zizyphinus (Linné, 1758) & & & & & & & & $*$ & $*$ & $*$ & $*$ & $*$ & & & & & & \\
\hline Danilia tinei (Calcara, 1839) & & & & & & & & & & $*$ & & & & & & & & \\
\hline Moelleria costulata (Møller, 1842) & & & & & & & & & & & $*$ & $*$ & $*$ & & & & & \\
\hline Skenea areolata (G.O. Sars, 1878) & & & & $*$ & & & & & & & & $*$ & & & & & & \\
\hline Skenea basistriata (Jeffreys, 1877) & & & & & & & & & $*$ & $*$ & $*$ & $*$ & & & & & & \\
\hline Skenea ossiansarsi Warén, 1991 & & & & & & & & & & $*$ & $*$ & $*$ & $*$ & & & & & $*$ \\
\hline Skenea peterseni (Friele, 1877) & & & $*$ & & & & & & & $*$ & $*$ & $*$ & & & & & & \\
\hline Skenea profunda (Friele, 1879) & $*$ & & & & $*$ & & & & & & & & & & & & & \\
\hline Skenea aff. proxima (Tryon, 1888) & & & & & & $*$ & & & & $*$ & & & & & & $*$ & & \\
\hline Skenea rugulosa (G.O. Sars, 1878) & & & & & & & & & $*$ & $*$ & $*$ & $*$ & $*$ & & & & & \\
\hline Skenea trochoides (Friele, 1876) & & & $*$ & & & & & & & $*$ & $*$ & $*$ & & & & & & * \\
\hline Skenea turgida (Odhner, 1912) & $*$ & & & & $*$ & & & & & & & & & & & & & \\
\hline Skenea n.sp. A & & & & & & $*$ & & & & $*$ & $*$ & & & & & $*$ & & \\
\hline Skenea n.sp. B & & & & & & & & & & & & $*$ & & & & $*$ & & \\
\hline $\begin{array}{l}\text { Anekes undulisculpta } \\
\text { Bouchet \& Warén, } 1979\end{array}$ & $*$ & & & & $*$ & & & & & & & & & & & & & \\
\hline Dikoleps nitens (Philippi, 1844) & & & & & & & & & & $*$ & $*$ & $*$ & & & & & & \\
\hline Eudaronia aperta (Sykes, 1925) & & & & & & & & & & $*$ & & & & $*$ & $*$ & & & \\
\hline Lissotesta turrita (Gaglini, 1987) & & & $*$ & & & & & & & $*$ & $*$ & & & & $*$ & & $*$ & \\
\hline Palazzia ausonia (Palazzi, 1988) & & & & & & & & & & $*$ & & & & & $*$ & & $*$ & \\
\hline Retigyra millipunctata (Friele, 1886) & & & & & & $*$ & & & & & & $*$ & & $*$ & & & & * \\
\hline Rugulina fragilis (G.O. Sars, 1878) & & & $*$ & & & $*$ & & & & $*$ & & $*$ & & & & & & * \\
\hline Trochaclis islandica Warén, 1989 & & & & & & & & & & $*$ & & & & & $*$ & & $*$ & \\
\hline Theodoxus fluviatilis (Linné, 1758 & $*$ & & & & & & & & & & & & & $*$ & $*$ & & & \\
\hline Bittium reticulatum (da Costa, 1778$)$ & & & & & & & & $*$ & $*$ & $*$ & $*$ & $*$ & & & & & & \\
\hline Turritella communis Risso, 1826 & & & & & & & & $*$ & $*$ & $*$ & $*$ & $*$ & & & & & & \\
\hline Marshallora adversa (Montagu, 1803) & & & & & & & & $*$ & $*$ & $*$ & & & & & & & & $*$ \\
\hline $\begin{array}{l}\text { Similiphora similior } \\
\text { (Bouchet \& Guillemot, 1978) }\end{array}$ & $*$ & & & & & & & & & & & & & $*$ & & & & \\
\hline $\begin{array}{l}\text { Cerithiopsis tubercularis } \\
\text { (Montagu, 1803) }\end{array}$ & & & & & & & & $*$ & $*$ & $*$ & $*$ & & & & & & & \\
\hline Cerithiopsis barleei Jeffreys, 1867 & & & & & & & & $*$ & $*$ & & & & & $*$ & & & & \\
\hline Cerithiella metula (Lovén, 1846) & & & & & & $*$ & & $*$ & $*$ & $*$ & $*$ & $*$ & $*$ & & & & & \\
\hline $\begin{array}{l}\text { Krachia cossmanni } \\
\text { (Dautzenberg \& H. Fischer 1896) }\end{array}$ & & & & & & & & & & $*$ & & & & & $*$ & & & \\
\hline Laeocochlis sinistratus (Nyst, 1835) & & & & & & & & & $*$ & $*$ & $*$ & $*$ & * & & & & & \\
\hline
\end{tabular}


Table 2. Continued.

\begin{tabular}{|c|c|c|c|c|c|c|c|c|c|c|c|c|c|c|c|c|c|c|}
\hline & 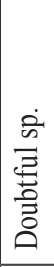 & $\begin{array}{l}0 \\
0 \\
0 \\
0 \\
z \\
0 \\
0 \\
0 \\
0 \\
0\end{array}$ & 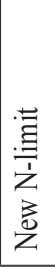 & 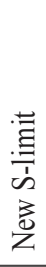 & 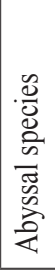 & 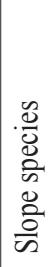 & 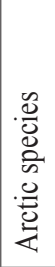 & $\frac{\sqrt{0}}{\frac{0}{0}}$ & 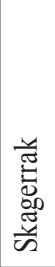 & 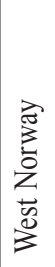 & 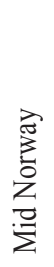 & 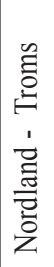 & 总 & 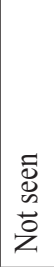 & 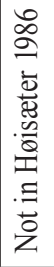 & 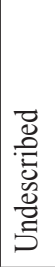 & 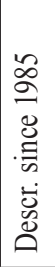 & 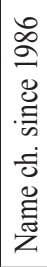 \\
\hline Eumetula arctica (Mørch, 1857) & & & & & & & & $*$ & $*$ & $*$ & $*$ & $*$ & $*$ & & & & & \\
\hline Eumetula n.sp. & & & & & & * & & & & $*$ & & & & & & $*$ & & \\
\hline Aclis ascaris (Turton, 1819) & & & & & & & & & $*$ & $*$ & & & & & & & & \\
\hline Aclis minor (Brown, 1827) & & & & & & & & $*$ & $*$ & $*$ & & & & & & & & \\
\hline $\begin{array}{l}\text { Aclis sarsi } \\
\text { Dautzenberg \& H. Fischer, } 1912\end{array}$ & & & & & & & & $*$ & $*$ & $*$ & $*$ & $*$ & $*$ & & & & & \\
\hline Aclis walleri Jeffreys, 1867 & & & & & & & & & & $*$ & $*$ & $*$ & & & & & & \\
\hline $\begin{array}{l}\text { Epitonium clathratulum } \\
\text { (Kanmacher, 1798) }\end{array}$ & & & & & & & & & $*$ & & & & & $*$ & & & & \\
\hline Epitonium clathrus (Linné, 1758) & & & $*$ & & & & & $*$ & $*$ & $*$ & & $*$ & & & & & & \\
\hline Epitonium greenlandicum (Perry, 1811) & & & & & & & & $*$ & & $*$ & $*$ & $*$ & $*$ & & & & & \\
\hline Epitonium trevelyanum (Johnston, 1841) & & & $*$ & & & & & $*$ & $*$ & $*$ & & & & & & & & \\
\hline Epitonium turtonis (Turton, 1819) & & & & & & & & $*$ & $*$ & $*$ & & & & $*$ & & & & \\
\hline Acirsa coarctata (Jeffreys, 1884) & & & & & & & & & & & & $*$ & $*$ & $*$ & & & & $*$ \\
\hline Gregorioiscala sarsi (Kobelt, 1904) & & & & & & & & & & $*$ & & & & $*$ & & & & $*$ \\
\hline Eulima bilineata Alder, 1848 & & & & & & & & $*$ & $*$ & $*$ & $*$ & $*$ & $*$ & & & & & \\
\hline Eulima n. sp. & & & & & & & & & & & & $*$ & & & & $*$ & & \\
\hline Bathycrinicola curta (Warén, 1972) & & & & & & & & & & $*$ & $*$ & & & & & & & $*$ \\
\hline $\begin{array}{l}\text { Crinolamia dahli } \\
\text { Bouchet \& Warén, } 1979\end{array}$ & & & & & * & * & & & & $*$ & & & & & & & & \\
\hline $\begin{array}{l}\text { Curveulima macrophthalmica } \\
\text { (Warén, 1972) }\end{array}$ & & & & & & & & & & $*$ & $*$ & $*$ & & & & & & $*$ \\
\hline Enteroxenos oestergreni Bonnevie, 1902 & & & & & & & & $*$ & $*$ & $*$ & $*$ & $*$ & $*$ & & & & & \\
\hline Entocolax sp. & $*$ & & & & & & & & & $*$ & & & & $*$ & & & & \\
\hline Haliella stenostoma (Jeffreys, 1858) & & & & & & & & $*$ & $*$ & $*$ & $*$ & $*$ & & & & & & \\
\hline Halielloides nitidus (Verrill, 1884) & & & & & & & & & & & $*$ & $*$ & $*$ & & $*$ & & & $*$ \\
\hline Hemiaclis ventrosus (Friele, 1876) & & & & & & & & & & $*$ & $*$ & $*$ & & & & & & \\
\hline Melanella alba (da Costa, 1778) & & & $*$ & & & & & $*$ & & $*$ & $*$ & & & & & & & \\
\hline Melanella frielei (Jordan, 1895) & & & & & & & & & $*$ & $*$ & $*$ & $*$ & $* ?$ & & & & & \\
\hline Melanella laurae (Friele, 1886) & & & & & & * & & & & & & $*$ & & & & & & \\
\hline Melanella lubrica (Monterosato, 1890) & & & $*$ & & & & & $*$ & $*$ & $*$ & $*$ & $* ?$ & & & & & & \\
\hline $\begin{array}{l}\text { Melanella monterosatoi } \\
\text { (Monterosato, 1890) }\end{array}$ & & & & & & & & & $*$ & $*$ & $*$ & & & & & & & $*$ \\
\hline Melanella orphanensis Clarke, 1974 & & & & & & & & & & & $*$ & $*$ & & $*$ & $*$ & & & $*$ \\
\hline Melanella cf. polita (Linné, 1758) & & & & & & & & & & * & & & & & $*$ & & & $*$ \\
\hline $\begin{array}{l}\text { Melanella turrita } \\
\text { Bouchet \& Warén, } 1986\end{array}$ & & & & & & & & & & & $*$ & & & $*$ & $*$ & & $*$ & \\
\hline Pelseneeria stylifera (Turton, 1825) & & & & & & & & * & & * & & & & & & & & \\
\hline Vitreolina n.spp. & & & & & & & & $*$ & $*$ & $*$ & $*$ & $*$ & & & & $*$ & & $*$ \\
\hline
\end{tabular}


Table 2. Continued.

\begin{tabular}{|c|c|c|c|c|c|c|c|c|c|c|c|c|c|c|c|c|c|c|}
\hline & 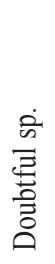 & $\begin{array}{l}\text { 感 } \\
0 \\
0 \\
0 \\
0 \\
0 \\
0\end{array}$ & 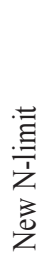 & 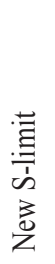 & 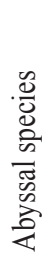 & 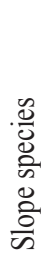 & 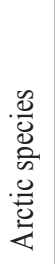 & $\begin{array}{l}\frac{D}{0} \\
\text { 总 } \\
\frac{0}{0} \\
\frac{0}{0} \\
0\end{array}$ & 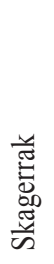 & 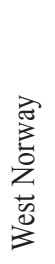 & 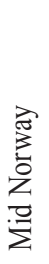 & 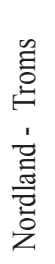 & 总志 & 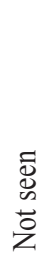 & 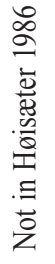 & 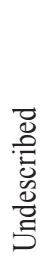 & 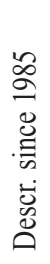 & 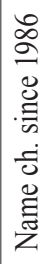 \\
\hline Littorina arcana Hannaford Ellis, 1978 & & & & & & & & & & & $*$ & $*$ & * & $*$ & & & & \\
\hline Littorina compressa Jeffreys, 1865 & & & & & & & & & & & & $*$ & $*$ & $*$ & & & & $*$ \\
\hline Littorina fabalis (Turton, 1825) & & & & & & & & $*$ & $*$ & $*$ & $*$ & $*$ & $*$ & & & & & $*$ \\
\hline Littorina littorea (Linné, 1758) & & & & & & & & $*$ & $*$ & $*$ & $*$ & $*$ & $*$ & & & & & \\
\hline Littorina obtusata (Linné, 1758) & & & & & & & & $*$ & $*$ & $*$ & $*$ & $*$ & $*$ & & & & & \\
\hline Littorina saxatilis (Olivi, 1792) & & & & & & & & $*$ & $*$ & $*$ & $*$ & $*$ & $*$ & & & & & \\
\hline Melarhaphe neritoides (Linné, 1758) & & & & & & & & $* ?$ & & $*$ & & & & & & & & $*$ \\
\hline Lacuna crassior (Montagu, 1803) & & & & & & & $* ?$ & & & & & & $*$ & $*$ & & & & \\
\hline Lacuna pallidula (da Costa, 1778) & & & & & & & & $*$ & $*$ & $*$ & $*$ & $*$ & $*$ & & & & & \\
\hline Lacuna parva (da Costa, 1778) & & & $*$ & & & & & & * & $*$ & & & & & & & & \\
\hline Lacuna vincta (Montagu, 1803) & & & & & & & & $*$ & $*$ & $*$ & $*$ & $*$ & $*$ & & & & & \\
\hline $\begin{array}{l}\text { Skeneopsis planorbis } \\
\text { (O. Fabricius, 1780) }\end{array}$ & & & & & & & & $*$ & $*$ & $*$ & $*$ & $*$ & $*$ & & & & & \\
\hline Rissoa lilacina Récluz, 1843 & & & & & & & & $*$ & $*$ & $*$ & $*$ & $*$ & & & & & & $*$ \\
\hline Rissoa membranacea (J. Adams, 1800) & & & & & & & & $*$ & $*$ & $*$ & $*$ & $*$ & & & & & & \\
\hline Rissoa parva (da Costa, 1778) & & & & & & & & $*$ & * & $*$ & $*$ & $*$ & $*$ & & & & & \\
\hline Pusillina inconspicua (Alder, 1844) & & & & & & & & $*$ & $*$ & $*$ & $*$ & $*$ & $*$ & & & & & \\
\hline Pusillina sarsii (Lovén, 1846) & & & $*$ & & & & & $*$ & $*$ & $*$ & $*$ & & & & & & & \\
\hline Alvania beani (Hanley in Thorpe, 1844) & & & $*$ & & & & & $*$ & $*$ & $*$ & $*$ & $*$ & & & & & & \\
\hline Alvania cimicoides (Forbes, 1844) & & & & & & & & $*$ & $*$ & $*$ & $*$ & $*$ & $*$ & & & & & \\
\hline Alvania incognita Warén, 1996 & & $*$ & & & & $*$ & & & & & & $*$ & & & $*$ & & $*$ & \\
\hline Alvania jeffreysi (Waller, 1864) & & & & & & & & $*$ & $*$ & $*$ & $*$ & $*$ & $*$ & & & & & \\
\hline Alvania moerchi (Collin, 1886) & & $*$ & & & & $*$ & & & & $*$ & & & & & $*$ & & & \\
\hline Alvania aff. moerchi (Collin, 1886) & & & & & & $*$ & & & & & & $*$ & & & & $*$ & & \\
\hline Alvania pseudosyngenes (Warén, 1973) & & & & & & $*$ & & & & & & $*$ & & $*$ & & & & \\
\hline Alvania punctura (Montagu, 1803) & & & & & & & & $*$ & $*$ & $*$ & $*$ & $*$ & $*$ & & & & & \\
\hline Alvania subsoluta (Aradas, 1847) & & & & & & & & $*$ & $*$ & $*$ & $*$ & $*$ & & & & & & \\
\hline Alvania cf. scrobiculata (Møller, 1842) & & & & & & & $*$ & & & & & & & & & & & \\
\hline $\begin{array}{l}\text { Alvania testae } \\
\text { (Aradas \& Maggiore, 1844) }\end{array}$ & & & & & & & & & $*$ & $*$ & $*$ & & & & & & & $*$ \\
\hline Alvania verrilli (Friele, 1886) & & & & & & $*$ & & & & & & $*$ & & $*$ & & & & \\
\hline Alvania wyvillethomsoni (Friele, 1877) & & & & & & $*$ & & & & $*$ & $*$ & $*$ & & & & & & \\
\hline Alvania zetlandica (Montagu, 1815) & & & $*$ & & & & & $*$ & & $*$ & $*$ & $*$ & & & & & & $*$ \\
\hline Alvania n.sp. & & & & & & & & & & $*$ & & & & & & $*$ & & \\
\hline Boreocingula castanea (Møller, 1842) & & & & & & & $*$ & & & & & & $*$ & $*$ & $*$ & & & \\
\hline Cingula trifasciata (J. Adams, 1800) & & & & & & & & & $*$ & $*$ & $*$ & & & & & & & \\
\hline Crisilla semistriata (Montagu, 1808) & & & & & & & & $*$ & & $*$ & $*$ & & & & & & & $*$ \\
\hline Frigidoalvania janmayeni (Friele, 1878) & & & & & & & $*$ & & & & & & $*$ & & & & & \\
\hline
\end{tabular}


Table 2. Continued.

\begin{tabular}{|c|c|c|c|c|c|c|c|c|c|c|c|c|c|c|c|c|c|c|}
\hline & 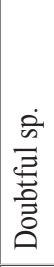 & 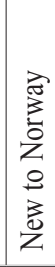 & 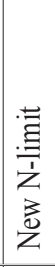 & 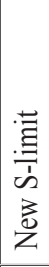 & 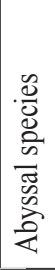 & 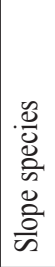 & 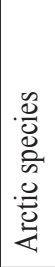 & 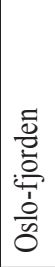 & 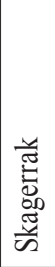 & 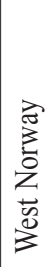 & 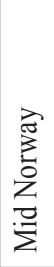 & 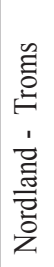 & 兰总 & 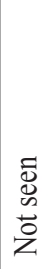 & 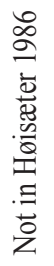 & 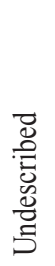 & 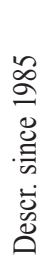 & 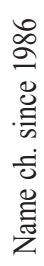 \\
\hline Manzonia crassa (Kanmacher, 1798) & $*$ & & & & & & & $*$ & & * & & & & & & & & \\
\hline Obtusella intersecta (S.V. Wood, 1841) & & & & & & & & & $*$ & $*$ & $*$ & $*$ & & & & & & $*$ \\
\hline Obtusella tumidula (G.O. Sars, 1878) & & & & $*$ & & $*$ & $*$ & & & & & & * & & & & & \\
\hline Onoba aculeus (Gould, 1841) & & & & & & & & $*$ & * & $*$ & $*$ & $*$ & $*$ & & & & & \\
\hline Onoba islandica (Friele, 1886) & & $*$ & & & & $*$ & & & & & * & & & & $*$ & & & \\
\hline Onoba semicostata (Montagu, 1803) & & & & & & & & $*$ & $*$ & $*$ & $*$ & $*$ & & & & & & \\
\hline Onoba cf. improcera Warén 1996 & & & & & & & & & & & & $*$ & & & $*$ & & * & \\
\hline Pseudosetia semipellucida (Friele, 1879) & $*$ & & & & $*$ & & & & & & & & & & & & & $*$ \\
\hline Pseudosetia turgida (Jeffreys, 1870) & & & & & & & & * & $*$ & $*$ & $*$ & $*$ & $*$ & & & & & $*$ \\
\hline Caecum glabrum (Montagu, 1803) & & & $*$ & & & & & $*$ & & * & * & & & & & & & \\
\hline Elachisina globuloides (Warén, 1972) & $*$ & & & & & & & & & * & & & & $*$ & & & & $*$ \\
\hline Hydrobia neglecta Muus, 1963 & & & & & & & & $*$ & $*$ & $*$ & $*$ & $*$ & $*$ & $*$ & & & & \\
\hline Hydrobia ulvae (Pennant, 1777) & & & $*$ & & & & & $*$ & * & * & * & * & * & & & & & \\
\hline $\begin{array}{l}\text { Potamopyrgus antipodarum } \\
\text { (Gray, 1843) }\end{array}$ & & & & & & & & & * & & & & & $*$ & & & & $*$ \\
\hline Ventrosia ventrosa (Montagu, 1803) & & & & & & & & $*$ & $*$ & & & & & $*$ & & & & $*$ \\
\hline $\begin{array}{l}\text { Ceratia proxima } \\
\text { (Forbes \& Hanley, 1850) }\end{array}$ & $*$ & & & & & & & & & $*$ & & & & & $*$ & & & \\
\hline Hyala vitrea (Montagu, 1803) & & & $*$ & & & & & $*$ & $*$ & $*$ & & & & & & & & \\
\hline Circulus sarsi (Bush, 1898) & $*$ & & & & & & & & & & $*$ & $*$ & & & & & & $*$ \\
\hline Aporrhais pespelecani (Linné, 1758) & & & & & & & & $*$ & $*$ & $*$ & $*$ & $*$ & $*$ & & & & & \\
\hline Aporrhais serresianus (Michaud, 1828) & & & & & & & & & & $*$ & $*$ & $*$ & & & & & & \\
\hline Crepidula fornicata (Linné, 1758) & & & & & & & & & $*$ & $*$ & & & & & & & & \\
\hline Capulus ungaricus (Linné, 1758) & & & & & & & & $*$ & $*$ & $*$ & $*$ & $*$ & $*$ & & & & & \\
\hline Torellia delicata (Philippi, 1844) & & & & & & & & & & $*$ & $*$ & $*$ & & & & & & $*$ \\
\hline $\begin{array}{l}\text { Trichotropis borealis } \\
\text { Broderip \& G.B. Sowerby I, } 1829\end{array}$ & & & & & & & & & & $*$ & $*$ & $*$ & $*$ & & & & & \\
\hline Trichotropis conicus Møller, 1842 & & & & $*$ & & & & & & & & $*$ & $*$ & & & & & \\
\hline Trichotropis cf. borealis & & & & & & & & & & & & $*$ & & & & $*$ & & \\
\hline Trichotropis n. sp. & & & & & & & & & & & & $*$ & & & & $*$ & & \\
\hline Velutina lanigera Møller, 1842 & & & & & & & & & & & & $*$ & $*$ & $*$ & & & & \\
\hline Velutina plicatilis (O.F. Müller, 1776) & & & & & & & & $*$ & $*$ & $*$ & $*$ & $*$ & $*$ & & & & & \\
\hline Velutina schneideri Friele, 1886 & & & & & & & & & & & & $*$ & & $*$ & & & & \\
\hline Velutina undata J. Smith, 1839 & & & & & & & & & & & $*$ & $*$ & $*$ & & & & & \\
\hline Velutina velutina (O.F. Müller, 1776) & & & & & & & & $*$ & $*$ & $*$ & $*$ & $*$ & $*$ & & & & & \\
\hline Onchidiopsis glacialis (M. Sars, 1851) & & & & & & & & & & & & $*$ & $*$ & $*$ & & & & \\
\hline Piliscus radiatus (M. Sars, 1851) & & & & & & $*$ & & & & & & & $*$ & $*$ & & & & $*$ \\
\hline Lamellaria latens (O.F. Müller, 1776) & & & & & & & & & & $*$ & $*$ & $*$ & $*$ & & & & & \\
\hline
\end{tabular}


Table 2. Continued.

\begin{tabular}{|c|c|c|c|c|c|c|c|c|c|c|c|c|c|c|c|c|c|c|}
\hline & 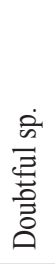 & $\begin{array}{l}2 \\
0 \\
0 \\
0 \\
0 \\
0 \\
0 \\
z \\
0 \\
z\end{array}$ & 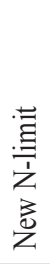 & 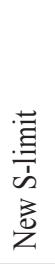 & 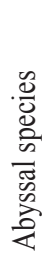 & 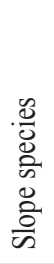 & 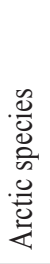 & 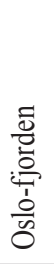 & 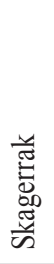 & 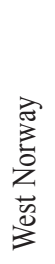 & 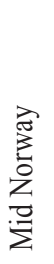 & 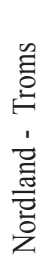 & $\begin{array}{l}\text { 岂 } \\
\text { 蓄 } \\
\text { 拄 }\end{array}$ & 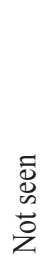 & 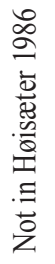 & 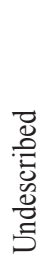 & 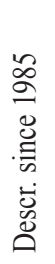 & 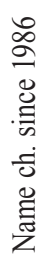 \\
\hline Lamellaria perspicua (Linné, 1758) & & & & & & & & $*$ & $*$ & $*$ & $*$ & & & & & & & \\
\hline $\begin{array}{l}\text { Calyptoconcha cf. pellucida } \\
\text { (Verrill, 1880) }\end{array}$ & & & & * & & & & & & $*$ & $*$ & & & & & & & * \\
\hline Marseniella borealis Bergh, 1886 & & & & & & & & & & $*$ & & & & $*$ & & & & \\
\hline Marsenina glabra (Couthouy, 1839) & & & & & & & & & & $*$ & $*$ & $*$ & $*$ & $*$ & & & & \\
\hline Trivia arctica (Pulteney, 1799) & & & & & & & & $*$ & $*$ & $*$ & $*$ & $*$ & & & & & & \\
\hline Erato voluta (Montagu, 1803) & & & & & & & & & $*$ & & & & & & & & & \\
\hline Cryptonatica affinis (Gmelin, 1791) & & & & & & & & & & $*$ & $*$ & $*$ & $*$ & & & & & $*$ \\
\hline Cryptonatica bathybii (Friele, 1879) & & & & & $*$ & $*$ & & & & & $*$ & $*$ & & & & & & $*$ \\
\hline Euspira montagui (Forbes, 1838) & & & & & & & & $*$ & $*$ & $*$ & $*$ & $*$ & * & & & & & $*$ \\
\hline $\begin{array}{l}\text { Euspira pallida } \\
\text { (Broderip \& G.B. Sowerby I, 1829) }\end{array}$ & & & & & & & & $*$ & $*$ & $*$ & $*$ & $*$ & * & & & & & $*$ \\
\hline Euspira pulchella (Risso, 1826) & & & & & & & & $*$ & $*$ & $*$ & $*$ & $*$ & & & & & & * \\
\hline Euspira sp. & $*$ & & & & & & & & & & & $*$ & & & & $*$ & & \\
\hline Amauropsis islandica (Gmelin, 1791) & & & & & & & & & $*$ & * & * & $*$ & * & & & & & \\
\hline Bulbus smithi (Brown, 1839) & & & & & & & & & & & & $*$ & * & & & & & \\
\hline Pseudopolinices nanus (Møller, 1842) & & & & & & & $*$ & & & & & & $*$ & & & & & $*$ \\
\hline Nucella lapillus (Linné, 1758) & & & & & & & & $*$ & $*$ & $*$ & $*$ & * & * & & & & & \\
\hline $\begin{array}{l}\text { Trophonopsis barvicensis } \\
\text { (Johnston, 1825) }\end{array}$ & & & & & & & & $*$ & $*$ & $*$ & $*$ & $*$ & $*$ & & & & & \\
\hline Boreotrophon clathratus (Linné, 1767) & & & & & & & & & & & & * & * & & & & & * \\
\hline Boreotrophon clavatus (G.O. Sars, 1878) & & & $*$ & & & & & $*$ & & $*$ & $*$ & $*$ & $*$ & & & & & $*$ \\
\hline Boreotrophon truncatus (Strøm, 1768) & & & & & & & & $*$ & $*$ & $*$ & $*$ & $*$ & $*$ & & & & & * \\
\hline Scabrotrophon fabricii (Møller, 1842) & $*$ & & & & & & $*$ & & & & & & & $*$ & & & & $*$ \\
\hline $\begin{array}{l}\text { Metzgeria alba } \\
\text { (Wyville-Thomson, 1873) }\end{array}$ & & & & & & & & & $*$ & $*$ & $*$ & $*$ & $*$ & & & & & $*$ \\
\hline Volutomitra groenlandica (Møller, 1842) & & & & & & & & & & $*$ & & $*$ & & * & & & & \\
\hline Buccinum cyaneum Bruguière, 1792 & & & & & & & & & & & & $*$ & * & $*$ & & & & \\
\hline $\begin{array}{l}\text { Buccinum finmarkianum } \\
\text { Verkrüzen, } 1875\end{array}$ & & & & & & & & & & & & $*$ & $*$ & & & & & * \\
\hline $\begin{array}{l}\text { Buccinum humphreysianum } \\
\text { Bennett, } 1824\end{array}$ & & & & & & & & & $*$ & $*$ & $*$ & $*$ & $*$ & & & & & \\
\hline Buccinum hydrophanum Hancock, 1846 & & & & & & & & & & & $*$ & & $*$ & & & & & \\
\hline $\begin{array}{l}\text { Buccinum kjennerudae } \\
\text { Bouchet \& Warén, } 1985\end{array}$ & & & & & & $*$ & & & & & & $*$ & & * & $*$ & & & * \\
\hline Buccinum nivale Friele, 1882 & & & & & & $*$ & & & & & & $*$ & & $*$ & & & & \\
\hline Buccinum oblitum Sykes, 1911 & & & & & & $*$ & & & & $*$ & & $*$ & & & * & & & \\
\hline Buccinum scalariforme Møller, 1842 & $*$ & & & & & & $*$ & & & & & & & $*$ & & & & \\
\hline Buccinum tumidulum G.O. Sars, 1878 & & & & & & & $*$ & & & & & & $*$ & $*$ & & & & \\
\hline
\end{tabular}


Table 2. Continued.

\begin{tabular}{|c|c|c|c|c|c|c|c|c|c|c|c|c|c|c|c|c|c|c|}
\hline & 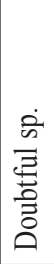 & 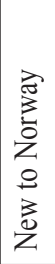 & 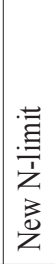 & 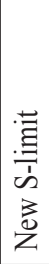 & 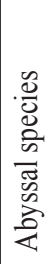 & 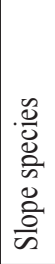 & 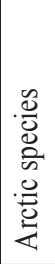 & 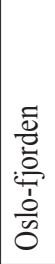 & 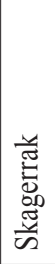 & 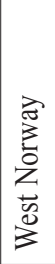 & 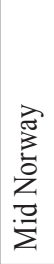 & 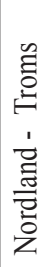 & 兰䔍 & 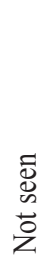 & 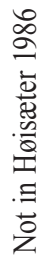 & 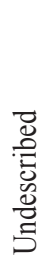 & 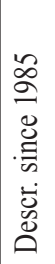 & 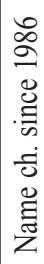 \\
\hline Buccinum undatum Linné, 1758 & & & & & & & & * & * & * & * & $*$ & $*$ & & & & & \\
\hline Beringius turtoni (Bean, 1834) & & & & & & & & & & $*$ & $*$ & $*$ & $*$ & & & & & \\
\hline Colus gracilis (da Costa, 1778) & & & & & & & & & & * & * & $*$ & $*$ & & & & & \\
\hline Colus holboelli (Møller, 1842) & & & & & & & & & & * & * & $*$ & $*$ & & & & & $*$ \\
\hline Colus islandicus (Mohr, 1786) & & & & & & & & & $*$ & $*$ & $*$ & $*$ & $*$ & & & & & \\
\hline Colus jeffreysianus (P. Fischer, 1868) & & & & & & & & & $*$ & $*$ & & & & $*$ & & & & \\
\hline Colus latericeus (Møller, 1842) & & & & & & & & & & & & $*$ & $*$ & & & & & \\
\hline Colus sabini (J.E. Gray, 1824) & $*$ & & & & & $*$ & $*$ & & & & & & & & & & & $*$ \\
\hline Colus turgidulus (Friele, 1877) & & & & & & $*$ & & & & '* & & & & & & & & \\
\hline Colus verkruezeni (Kobelt, 1876) & & & & & & $*$ & $*$ & & & & & & $*$ & $*$ & & & & \\
\hline Liomesus ovum (Turton, 1825) & & & $*$ & & & & & & & $*$ & $*$ & $*$ & & & & & & \\
\hline Mohnia danielsseni (Friele, 1879) & $*$ & & & & $*$ & & & & & & & & & & & & & $*$ \\
\hline Mohnia glypta (Verrill, 1882) & & & & & & $*$ & & & & & & & & & $*$ & & & \\
\hline Mohnia mohni (Friele, 1877) & & & & & $*$ & $*$ & & & & & & $*$ & & & & & & \\
\hline Neptunea antiqua (Linné, 1758) & $*$ & & & & & & & $*$ & $*$ & $*$ & $*$ & & & $*$ & & & & \\
\hline Neptunea despecta (Linné, 1758) & & & & & & & & $*$ & $*$ & $*$ & $*$ & $*$ & $*$ & & & & & \\
\hline Troschelia berniciensis (King, 1846) & & & & & & & & & & $*$ & $*$ & $*$ & $*$ & & & & & \\
\hline Turrisipho dalli (Friele in Tryon, 1881) & & & & & & & & & & $*$ & & & $*$ & & & & & $*$ \\
\hline Turrisipho fenestratus (Turton, 1834) & & & & & & & & & & $*$ & $*$ & $*$ & $*$ & & & & & $*$ \\
\hline Turrisipho lachesis (Mørch, 1869) & & & & & & $*$ & $*$ & & & & & & $*$ & & & & & $*$ \\
\hline $\begin{array}{l}\text { Turrisipho moebii } \\
\text { (Dunker \& Metzger, 1874) }\end{array}$ & & & & & & & & & * & * & * & $*$ & $*$ & & & & & $*$ \\
\hline $\begin{array}{l}\text { Turrisipho voeringi } \\
\text { (Bouchet \& Warén, 1985) }\end{array}$ & & & & & & $*$ & $*$ & & & & & & $*$ & & $*$ & & & \\
\hline Volutopsius norwegicus (Gmelin, 1791) & & & & & & & & & & $*$ & $*$ & $*$ & $*$ & & & & & \\
\hline Nassarius incrassatus (Strøm, 1868) & & & & & & & & $*$ & $*$ & $*$ & $*$ & $*$ & $*$ & & & & & $*$ \\
\hline Nassarius pygmaeus (Lamarck, 1822) & & & & & & & & $*$ & $*$ & $*$ & & & & $*$ & & & & $*$ \\
\hline Nassarius nitidus (Jeffreys, 1867) & & & & & & & & $*$ & $*$ & $*$ & $*$ & & & & & & & $*$ \\
\hline Amphissa acutecostata (Philippi, 1844) & & & & & & & & & & $*$ & $*$ & $*$ & & & & & & $*$ \\
\hline Mitrella rosacea (Gould, 1840) & & & & & & & & & & $*$ & $*$ & $*$ & $*$ & & & & & $*$ \\
\hline Admete contabulata Friele, 1879 & & & & & & $*$ & & & & $*$ & & $*$ & & & & & & \\
\hline Admete viridula (Fabricius, 1780) & & & & & & & & $*$ & $*$ & $*$ & $*$ & $*$ & $*$ & & & & & \\
\hline Admete n.sp. & & & & & & $*$ & & & & $*$ & & & & & & $*$ & & \\
\hline Iphinopsis inflata (Friele, 1879) & & & & $*$ & & $*$ & & & & $*$ & & $*$ & & & & & & $*$ \\
\hline Typhlomangelia nivalis (Lovén, 1846) & & & & & & & & $*$ & $*$ & $*$ & $*$ & $*$ & $*$ & & & & & \\
\hline Oenopota assimilis (G.O. Sars, 1878) & & & & & & & & & & $*$ & $*$ & $*$ & $*$ & & & & & \\
\hline Oenopota bergensis (Friele, 1886) & & & & & & & & $*$ & & $*$ & $*$ & & & & & & & \\
\hline Oenopota elegans (Møller, 1842) & & & & & & & & $*$ & & $*$ & $*$ & $*$ & & & & & & $*$ \\
\hline
\end{tabular}


Table 2. Continued.

\begin{tabular}{|c|c|c|c|c|c|c|c|c|c|c|c|c|c|c|c|c|c|c|}
\hline & 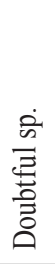 & $\begin{array}{l}2 \\
0 \\
0 \\
0 \\
z \\
0 \\
0 \\
z \\
0 \\
z\end{array}$ & 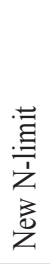 & 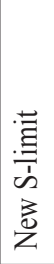 & 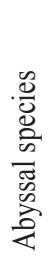 & 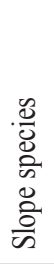 & 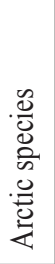 & 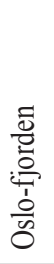 & 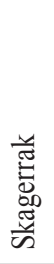 & 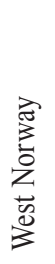 & 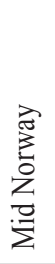 & 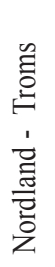 & 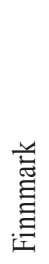 & 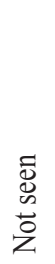 & 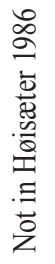 & 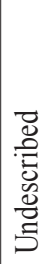 & 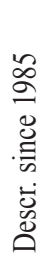 & 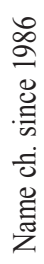 \\
\hline Oenopota exarata (Møller, 1842) & & & & & & & & $*$ & & & & & $*$ & & & & & \\
\hline Oenopota harpularia (Couthouy, 1839) & & & & & & & & & & & $*$ & $*$ & $*$ & & & & & \\
\hline Oenopota impressa (Mørch, 1869) & & & & & & & & & & & & $*$ & $*$ & & & & & \\
\hline Oenopota nobilis (sensu Stokland, 1981) & & & & & & & & & & & & $*$ & $*$ & & & & & \\
\hline Oenopota ovalis (Friele, 1877) & $*$ & & & & $*$ & & & & & & & & & & & & & \\
\hline Oenopota pyramidalis (Strøm, 1768) & & & & & & & & & & & & $*$ & $*$ & & & & & \\
\hline Oenopota tenuicostata (G.O. Sars, 1878) & & & & & & $*$ & & & & $*$ & $*$ & $*$ & $*$ & & & & & $*$ \\
\hline Oenopota trevelliana (Turton, 1834) & & & & & & & & $*$ & $*$ & $*$ & $*$ & $*$ & * & & & & & \\
\hline Oenopota turricula (Montagu, 1803) & & & $*$ & & & & & $*$ & & $*$ & & $*$ & & & & & & \\
\hline $\begin{array}{l}\text { Oenopota violacea } \\
\text { (Mighels \& Adams, 1842) }\end{array}$ & & & & & & & & $*$ & $*$ & $*$ & $*$ & $*$ & $*$ & & & & & \\
\hline Bela brachystoma (Philippi, 1844) & & & & & & & & $*$ & * & * & & & & & & & & * \\
\hline Bela costulata (Risso, 1826) & $*$ & & & & & & & & & & & & & $*$ & & & & $*$ \\
\hline Bela nebula (Montagu, 1803) & & & & & & & & & $*$ & $*$ & & & & $*$ & & & & $*$ \\
\hline Bela powisiana (Dautzenberg, 1887) & & & & & & & & $*$ & $*$ & & & & & $*$ & $*$ & & & \\
\hline Mangelia attenuata (Montagu, 1803) & & & * & & & & & $*$ & * & $*$ & & $*$ & & & & & & \\
\hline Mangelia coarctata (Forbes, 1840) & & & & & & & & $*$ & $*$ & $*$ & $*$ & & & & & & & \\
\hline Raphitoma aequalis (Jeffreys, 1867) & & $*$ & & & & & & $*$ & $*$ & $*$ & $*$ & * & * & & $*$ & & & $*$ \\
\hline Raphitoma concinna (Scacchi, 1836) & & & & & & & & $*$ & $*$ & $*$ & $*$ & & & & & & & $*$ \\
\hline Raphitoma echinata (Brocchi, 1814) & & & $*$ & & & & & & $*$ & $*$ & $*$ & $*$ & & & & & & $*$ \\
\hline Raphitoma linearis (Montagu, 1803) & & & & & & & & & $*$ & $*$ & & $*$ & & & & & & $*$ \\
\hline Raphitoma purpurea (Montagu, 1803) & & & $*$ & & & & & & $*$ & $*$ & $*$ & & & & & & & \\
\hline Raphitoma n. sp. & & & & & & & & & & $*$ & & $*$ & & & & $*$ & & \\
\hline Nepotilla amoena (G.O. Sars, 1878) & & & & & & & & & & & & $*$ & $*$ & & & & & \\
\hline Teretia teres (Reeve, 1844) & & & & & & & & $*$ & $*$ & $*$ & $*$ & $*$ & * & & & & & \\
\hline Pleurotomella packardi Verrill, 1872 & & & & & $*$ & $*$ & & & & & $*$ & $*$ & & & & & & \\
\hline Thesbia nana (Lovén, 1846) & & & $*$ & & & & & $*$ & $*$ & $*$ & $*$ & $*$ & $*$ & & & & & \\
\hline $\begin{array}{l}\text { Taranis borealis } \\
\text { Bouchet \& Warén, } 1980\end{array}$ & & & $*$ & & & & & & & $*$ & & $*$ & & & & & & \\
\hline Taranis moerchi (Malm, 1863) & & & & & & & & $*$ & $*$ & $*$ & $*$ & $*$ & $*$ & & & & & \\
\hline $\begin{array}{l}\text { Spirotropis modiolus } \\
\text { (de Cristofori \& Jan, 1832) }\end{array}$ & & & & & & & & & & $*$ & $*$ & $*$ & * & & & & & $*$ \\
\hline $\begin{array}{l}\text { Haedropleura septangularis } \\
\text { (Montagu, 1803) }\end{array}$ & $*$ & & & & & & & & & & & & & $*$ & & & & \\
\hline Turritellopsis stimpsoni Dall, 1919 & & & & & & & $*$ & & & & & & * & $*$ & & & & $*$ \\
\hline Rissoella diaphana (Alder, 1848) & & & $*$ & & & & & & & $*$ & & & & & & & & \\
\hline $\begin{array}{l}\text { Rissoella globularis } \\
\text { (Forbes \& Hanley, 1853) }\end{array}$ & & & & & & & & & & $*$ & $*$ & $*$ & & & & & & \\
\hline
\end{tabular}


Table 2. Continued.

\begin{tabular}{|c|c|c|c|c|c|c|c|c|c|c|c|c|c|c|c|c|c|c|}
\hline & 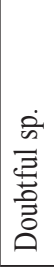 & 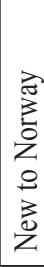 & 咅 & 节 & 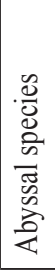 & 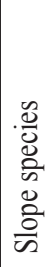 & 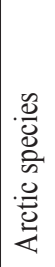 & 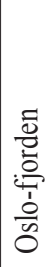 & 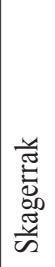 & 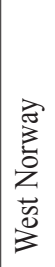 & 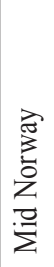 & 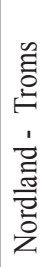 & 急 & $\begin{array}{l}\tilde{D} \\
\mathbb{d} \\
\infty \\
\tilde{0} \\
z\end{array}$ & 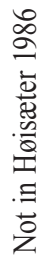 & 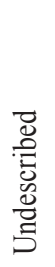 & 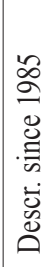 & 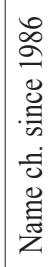 \\
\hline Rissoella opalina (Jeffreys, 1848) & $*$ & & & & & & & & & & & & & $*$ & & & & \\
\hline Omalogyra atomus (Philippi, 1841) & & & & & & & & $*$ & * & * & $*$ & & * & & & & & \\
\hline $\begin{array}{l}\text { Ammonicera rota } \\
\text { (Forbes \& Hanley, 1850) }\end{array}$ & & & $*$ & & & & & & & $*$ & $*$ & & & & & & & \\
\hline $\begin{array}{l}\text { Xylodiscula planata } \\
\text { Høisæter \& Johannessen, } 2001\end{array}$ & & & & & & & & & & * & & & & & $*$ & & $*$ & \\
\hline Aartsenia candida (Møller, 1842) & $*$ & & & & & & $*$ & & & & & & & $*$ & & & & \\
\hline Chrysallida bjoernssoni Warén, 1991 & $*$ & $*$ & & & & & & & & $*$ & & $*$ & & & $*$ & & $*$ & \\
\hline Chrysallida brattstroemi Warén, 1991 & & & $*$ & & & & & & & $*$ & $*$ & $*$ & & & $*$ & & $*$ & \\
\hline Chrysallida eximia (Jeffreys, 1849) & & & & & & & & $*$ & $*$ & $*$ & $*$ & $*$ & $*$ & & & & & \\
\hline Chrysallida hoeisaeteri Warén, 1991 & & & $*$ & & & & & & & $*$ & & $*$ & & & $*$ & & $*$ & \\
\hline Chrysallida indistincta (Montagu, 1808) & & & * & & & & & * & * & $*$ & * & * & & & & & & \\
\hline $\begin{array}{l}\text { Chrysallida interstincta } \\
\text { (J. Adams, 1797) }\end{array}$ & & & & & & & & $*$ & $*$ & $*$ & $*$ & $*$ & & & & & & $*$ \\
\hline Chrysallida nivosa (Montagu, 1803) & & $*$ & & & & & & & & * & & & & & & & & $*$ \\
\hline Chrysallida pellucida (Dillwyn, 1817) & & & & & & & & $*$ & $*$ & $*$ & $*$ & $*$ & $*$ & & & & & $*$ \\
\hline Chrysallida sarsi (Nordsick, 1972) & $*$ & & & & & & & & & $*$ & & & & $*$ & $*$ & & & \\
\hline Chrysallida sublustris (Friele, 1886) & & & & & & $*$ & & & & $*$ & & $*$ & & & & & & $*$ \\
\hline Chrysallida truncatula (Jeffreys, 1850) & $*$ & & & & & & & & $*$ & & & & & & $*$ & & & \\
\hline Eulimella acicula (Philippi, 1836) & & & & & & & & $*$ & $*$ & $*$ & $*$ & $*$ & & & & & & $*$ \\
\hline Eulimella ataktos Warén, 1991 & & & $*$ & & & & & & & $*$ & & $*$ & & & $*$ & & $*$ & \\
\hline $\begin{array}{l}\text { Eulimella 'compactilis' } \\
\text { (sensu G.O. Sars, 1878) }\end{array}$ & & & & & & & & & $*$ & $*$ & & $*$ & & & & & & \\
\hline Eulimella scillae (Scacchi, 1835) & & & & & & & & $*$ & $*$ & $*$ & $*$ & $*$ & $*$ & & & & & \\
\hline Eulimella ventricosa (Forbes, 1844) & & & & & & & & * & $*$ & $*$ & $*$ & $*$ & $*$ & & & & & $*$ \\
\hline Eulimella n. sp. & $*$ & & & & & & & & & $*$ & & & & & & $*$ & & \\
\hline Odostomia acuta Jeffreys, 1848 & & & & & & & & $*$ & $*$ & $*$ & $*$ & $*$ & $*$ & & & & & \\
\hline Odostomia cf. angusta (Jeffreys, 1867) & $*$ & $*$ & & & & & & & & $*$ & $*$ & $*$ & & & $*$ & & & \\
\hline $\begin{array}{l}\text { Odostomia carrozzai } \\
\text { (van Aartsen, 1987) }\end{array}$ & & & $*$ & & & & & & & $*$ & $*$ & & & & & & & $*$ \\
\hline Odostomia conoidea (Brocchi, 1814) & & & $*$ & & & & & $*$ & $*$ & $*$ & $*$ & $*$ & & & & & & \\
\hline Odostomia conspicua Alder, 1850 & & & & & & & & & $*$ & & & & & & $*$ & & & \\
\hline Odostomia eulimoides (Hanley, 1844) & & & & $*$ & & & & $*$ & $*$ & $*$ & & $*$ & & & $*$ & & & \\
\hline Odostomia lukisi Jeffreys, 1859 & & & & & & & & & & * & & & & & & & & \\
\hline Odostomia cf. plicata (Montagu, 1803) & $*$ & & & & & & & & & $*$ & & & & & & & & \\
\hline Odostomia scalaris MacGillivray, 1843 & & & $*$ & & & & & $*$ & $*$ & $*$ & $*$ & $*$ & & & & & & $*$ \\
\hline $\begin{array}{l}\text { Odostomia striolata } \\
\text { Forbes \& Hanley, } 1850\end{array}$ & & $*$ & & & & & & & & $*$ & & & & & & & & $*$ \\
\hline Odostomia cf. turgida G.O. Sars, 1878 & & & & $*$ & & & & & & $*$ & & $*$ & & & & & & \\
\hline
\end{tabular}


Table 2. Continued.

\begin{tabular}{|c|c|c|c|c|c|c|c|c|c|c|c|c|c|c|c|c|c|c|}
\hline & 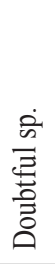 & $\begin{array}{l}2 \\
0 \\
0 \\
0 \\
z \\
0 \\
0 \\
z \\
0 \\
z\end{array}$ & 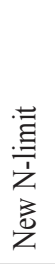 & 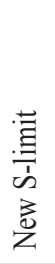 & 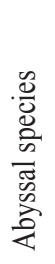 & 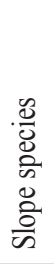 & 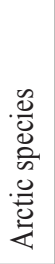 & 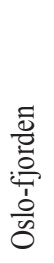 & 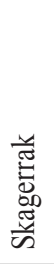 & 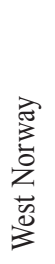 & 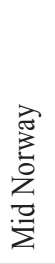 & 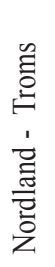 & $\begin{array}{l}\text { 岂 } \\
\text { 蓄 } \\
\text { 拄 }\end{array}$ & 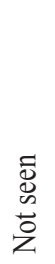 & 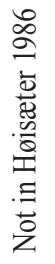 & 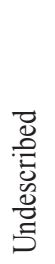 & 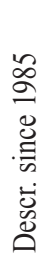 & 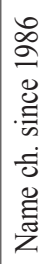 \\
\hline Odostomia turrita Hanley, 1844 & & & & & & & & $*$ & $*$ & $*$ & $*$ & $*$ & & & & & & \\
\hline Odostomia unidentata (Montagu, 1803) & & & & & & & & $*$ & $*$ & $*$ & $*$ & $*$ & * & & & & & \\
\hline Odostomia sp. A & $*$ & & & & & & & & & $*$ & & & & & & $*$ & & \\
\hline Liostomia afzelii Warén, 1991 & & & $*$ & * & & & & & $*$ & $*$ & & & & & * & & * & \\
\hline Liostomia clavula (Lovén, 1846) & & & & & & & & $*$ & $*$ & $*$ & & & & & & & & $*$ \\
\hline Liostomia eburnea (Stimpson, 1851) & & & & & & & $*$ & & & & & & * & $*$ & & & & \\
\hline Liostomia hansgei Warén, 1991 & & & $*$ & & & & & & & * & $*$ & * & & & * & & $*$ & \\
\hline Ondina coarctata (G.O. Sars, 1878) & $*$ & & & $*$ & & & & & & & $*$ & $*$ & $*$ & & & & & * \\
\hline Ondina diaphana (Jeffreys, 1848) & & & * & & & & & & & $*$ & & & & & & & & * \\
\hline Ondina divisa (J. Adams, 1797) & & & & & & & & $*$ & $*$ & $*$ & $*$ & $*$ & & & & & & * \\
\hline Ondina normani (Friele, 1886) & & & & $*$ & & & & & $*$ & * & $*$ & * & & & & & & * \\
\hline Ondina obliqua (Alder, 1844) & & $*$ & & & & & & & & * & & & & & & & & * \\
\hline $\begin{array}{l}\text { Ondina perezi } \\
\text { (Dautzenberg \& Fischer, 1925) }\end{array}$ & $*$ & & & & & & & & & $*$ & & & & & $*$ & & & $*$ \\
\hline Ondina cf. warreni (Thompson, 1845) & & & & $*$ & & & & $*$ & * & & & & & & & & & * \\
\hline Rissopsetia cf. islandica Warén, 1989 & $*$ & $*$ & & & & & & & & & & * & & & * & & * & \\
\hline Turbonilla crenata (Brown, 1827) & & & & & & & & $*$ & $*$ & $*$ & $*$ & $*$ & & & & & & * \\
\hline Turbonilla lactea (Linné, 1767) & $*$ & & & & & & & & & & & & & $*$ & & & & * \\
\hline Turbonilla cf. pusilla (Philippi, 1844) & & $*$ & & & & & & & * & & & & & & * & & & \\
\hline Turbonilla rufa (Philippi, 1836) & & $*$ & & & & & & & & $*$ & & & & & $*$ & & & \\
\hline Turbonilla rufescens (Forbes, 1846) & & & $*$ & & & & & $*$ & $*$ & $*$ & $*$ & $*$ & & & & & & \\
\hline $\begin{array}{l}\text { Bacteridium cf. carinatum } \\
\text { (de Folin, 1870) }\end{array}$ & & $*$ & & & & & & & & $*$ & & & & & $*$ & & & \\
\hline Ebala nitidissima (Montagu, 1803) & & & $*$ & & & & & & $*$ & $*$ & $*$ & & & & & & & \\
\hline Cima cuticulata Warén, 1993 & & & & & & $*$ & & & & $*$ & & & & & * & & * & \\
\hline Cima inconspicua Warén, 1993 & & & & & & & & & & $*$ & & * & & & * & & $*$ & \\
\hline Cima minima (Jeffreys, 1858) & & & & & & & & & & $*$ & & & & & & & & \\
\hline Graphis albida (Kanmacher, 1798) & & & $*$ & & & & & & & $*$ & & & & & & & & \\
\hline Tjaernoeia exquisita (Jeffreys, 1883) & & $*$ & & & & & & & & * & & & & & $*$ & & & \\
\hline Tjaernoeia n.sp. & & & & & & & & & & $*$ & & & & & $*$ & $*$ & & \\
\hline Acteon tornatilis (Linné, 1758) & & & & & & & & $*$ & $*$ & $*$ & $*$ & $*$ & & & & & & \\
\hline Diaphana globosa (Lovén, 1846) & & & & & & & & $*$ & $*$ & $*$ & $*$ & * & & & & & & \\
\hline Diaphana hiemalis (Couthouy, 1839) & & & & & & & & & & * & $*$ & $*$ & & & * & & & \\
\hline Diaphana lactea (Jeffreys, 1877) & $*$ & & & & $*$ & & & & & & & & & & & & & \\
\hline Diaphana minuta Brown, 1827 & & & & & & & & $*$ & $*$ & $*$ & $*$ & $*$ & $*$ & & & & & \\
\hline $\begin{array}{l}\text { Colobocephalus costellatus } \\
\text { M. Sars, } 1870\end{array}$ & & & & & & & & $*$ & & $*$ & & & & & & & & \\
\hline Colpodaspis pusilla M. Sars, 1870 & & & & & & & & $*$ & & $*$ & & & & & & & & \\
\hline
\end{tabular}


Table 2. Continued.

\begin{tabular}{|c|c|c|c|c|c|c|c|c|c|c|c|c|c|c|c|c|c|c|}
\hline & 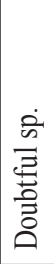 & 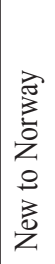 & 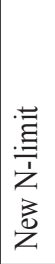 & 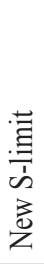 & 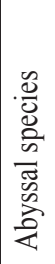 & 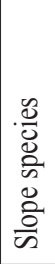 & 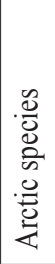 & 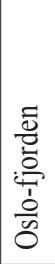 & 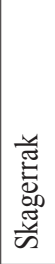 & 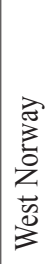 & 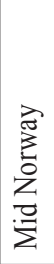 & 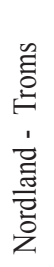 & 兰䔍 & 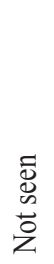 & 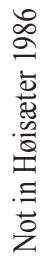 & 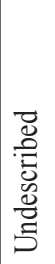 & 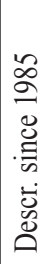 & 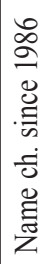 \\
\hline $\begin{array}{l}\text { Rhinodiaphana ventricosa } \\
\text { (Jeffreys, 1865) }\end{array}$ & & & & & & & & & & * & & $*$ & & $*$ & & & & \\
\hline Toledonia limnaeoides (Odhner, 1913) & & $*$ & & & & $*$ & $*$ & & & $*$ & & & & & $*$ & & & \\
\hline Retusa obtusa (Montagu, 1803) & & & & & & & & & $*$ & * & & $*$ & * & & & & & \\
\hline Retusa truncatula (Bruguière, 1792) & & & $*$ & & & & & $*$ & $*$ & $*$ & $*$ & $*$ & $*$ & & & & & \\
\hline Cylichnina umbilicata (Montagu, 1803) & & & & & & & & $*$ & * & * & * & $*$ & $*$ & & & & & \\
\hline Pyrunculus ovatus (Jeffreys, 1871) & & & & $*$ & & & & & & & * & $*$ & & & & & & \\
\hline Volvulella acuminata (Bruguière, 1792 & & & $*$ & & & & & $*$ & & $*$ & $*$ & & & & & & & \\
\hline Cylichnium africanum (Locard, 1897) & $*$ & & & & * & & & & & & & & & $*$ & & & & \\
\hline Johania cf. retifera (Forbes, 1844) & & $*$ & & & & & & & & $*$ & & & & & $*$ & & & \\
\hline Laona finmarchica (M. Sars, 1858) & & & & & & $*$ & & & & & & $*$ & $*$ & & & & & $*$ \\
\hline Laona flexuosa (M. Sars, 1870) & & & & & & & & * & * & * & & & & * & & & & * \\
\hline Laona pruinosa (W. Clark, 1827) & & & & & & & & $*$ & $*$ & $*$ & $*$ & $*$ & & & & & & $*$ \\
\hline Philine angulata Jeffreys, 1867 & & & $*$ & & & & & & & $*$ & & & & & & & & \\
\hline Philine aperta (Linné, 1767) & & & & & & & & $*$ & $*$ & $*$ & $*$ & $*$ & & & & & & \\
\hline Philine catena (Montagu, 1803) & & & & & & & & & $*$ & $*$ & $*$ & $*$ & & & & & & \\
\hline Philine denticulata (J. Adams, 1800) & & & & $*$ & & & & & & $*$ & & $*$ & & & & & & \\
\hline Philine infortunata Pilsbry, 1895 & & & & & & & & & & & & $*$ & & $*$ & & & & \\
\hline Philine lima (Brown, 1827) & & & & & & & & & & & $*$ & $*$ & $*$ & & & & & \\
\hline Philine punctata (J. Adams, 1800) & & & $*$ & & & & & $*$ & & $*$ & $*$ & & & & & & & \\
\hline Philine quadrata (S. Wood, 1839) & & & & & & & & $*$ & $*$ & $*$ & $*$ & $*$ & $*$ & & & & & \\
\hline Philine scabra (O.F. Müller, 1784) & & & & & & & & $*$ & $*$ & $*$ & $*$ & $*$ & $*$ & & & & & \\
\hline Cylichna alba (Brown, 1827) & & & & & & & & $*$ & $*$ & $*$ & $*$ & $*$ & $*$ & & & & & \\
\hline Cylichna cylindracea (Pennant, 1777) & & & & & & & & $*$ & $*$ & $*$ & $*$ & $*$ & & & & & & \\
\hline $\begin{array}{l}\text { Cylichna lemchei } \\
\text { Bouchet \& Warén, } 1979\end{array}$ & & & & & $*$ & $*$ & & & & & & & & & & & & \\
\hline $\begin{array}{l}\text { Cylichna occulta } \\
\text { (Mighels \& Adams, 1842) }\end{array}$ & & & & & & & $*$ & & & & & & $*$ & & & & & \\
\hline Roxania utriculus (Brocchi, 1814) & & & & & & & & & $*$ & $*$ & $*$ & & & & & & & \\
\hline Scaphander lignarius (Linné, 1758) & & & & & & & & $*$ & $*$ & $*$ & $*$ & $*$ & & & & & & \\
\hline $\begin{array}{l}\text { Scaphander punctostriatus } \\
\text { (Mighels \& Adams, 1842) }\end{array}$ & & & & & & & & $*$ & * & $*$ & $*$ & $*$ & $*$ & & & & & \\
\hline Akera bullata O.F. Müller, 1776 & & & & & & & & $*$ & $*$ & $*$ & $*$ & $*$ & $*$ & & & & & \\
\hline \multirow[t]{2}{*}{ Aplysia punctata Cuvier, 1803} & & & & & & & & & $*$ & $*$ & $*$ & $*$ & $*$ & & & & & \\
\hline & 38 & 16 & 47 & 13 & 14 & 38 & 19 & 142 & 157 & 266 & 197 & 222 & 140 & 54 & 49 & 18 & 16 & 97 \\
\hline
\end{tabular}




\section{REFERENCES}

Aartsen JJ van. 1981. European Pyramidellidae: II. Turbonilla. Bollettino Malacologico 17:61-88.

Aartsen JJ van. 1987. European Pyramidellidae: III. Odostomia and Ondina. Bollettino Malacologico 23:1-34.

Aartsen JJ van, Giannuzzi-Savelli R. 1991. New names for wellknown European marine Mollusca. Bollettino Malacologico 27:1-8.

Aartsen JJ van, Menkhorst HP, Gittenberger E. 1984. The marine Mollusca of the Bay of Algeciras, Spain, with general notes on Mitrella, Marginellidae and Turridae. Basteria Suppl. 2:1-135.

Adam W, Knudsen J. 1969. Quelques genres de mollusques prosobranches marins inconnus ou peu connus de l'Afrique occidentale. Bulletin du Institut royal des Sciences naturelles de Belgique 44(27):1-69.

Alexeyev DO. 2003. Gastropod Seashells of Russia. VNIRO Publishing, Moscow (In Russian and English)

Ankel WE. 1936. Prosobranchia. Tierwelt der Nord- und Ostsee 9b:1-240.

Barros JCN de, Mello RLS, Barros FN de, Santos MCF, Cabral E, Padovan IP. 2003. Sistemática dos gastrópodes Aclididae G.O. Sars, 1878 da plataforma continental e em águas profundas do Nordeste do Brasil. Boletim Técnico-Cientifico do CEPENE 11:1-29.

Beck T, Metzger T, Freiwald A. 2005. Biodiversity Inventorial Atlas (BIAS) of macrofunal associations from OASIS seamount study sites. -[http://wwwl.unihamburg.de/OASIS//Pages/ publications/ BIAS.pdf]

Bogdanov IP.1990. The mollusk subfamily Oenopotinae (Gastropoda, Pectinibranchia, Turridae) of the USSR seas. Mollusca, Vol.5, No.3. Fauna of the USSR New Series, No. 142. 223 p [in Russian, not seen].

Bouchet P. 1985. Les Triphoridae de Mediterranee et du proche Atlantique (Mollusca, Gastropoda). Lavori della Societa Italiana di Malacologia 21:5-58.

Bouchet P. 1996. Nouvelles observations sur la systematique des Triphoridae de Mediterranee et du proche Atlantique. Bollettino Malacologico 31:205-220.

Bouchet P, Guillemot H. 1978. The Triphora perversa-complex in Western Europe. Journal of Molluscan Studies 44:344-356.

Bouchet P, Warén A. 1979. The abyssal molluscan fauna of the Norwegian Sea and its relation to other faunas. Sarsia 64: 211243.

Bouchet P, Warén A. 1980. Revision of the North-East Atlantic bathyal and abyssal Turridae (Mollusca, Gastropoda). Journal of Molluscan Studies, Suppl. 8:1-119.

Bouchet P, Warén A. 1985. Revision of the Northeast Atlantic bathyal and abyssal Neogastropoda, excluding Turridae (Mollusca, Gastropoda). Bollettino Malacologico, Supplemento 1:123-296.

Bouchet P, Warén A. 1986. Revision of the Northeast Atlantic bathyal and abyssal Aclididae, Eulimidae, Epitoniidae (Mollusca, Gastropoda). Bollettino Malacologico, Supplemento 2:299-576.

Bouchet P, Warén A. 1993. Revision of the Northeast Atlantic bathyal and abyssal Mesogastropoda. Bollettino Malacologico, Supplemento 3:579-840.

Brøgger WC. 1872. Bidrag til Christianiafjordens Molluskfauna. Johan Dahl, Christiania. 43 pp.
Brown RW. 1956. Composition of Scientific Words. Revised Edition. Published by the author. Baltimore, Maryland. $882 \mathrm{pp}$.

Buhl-Mortensen L, Høisæter T. 1993. Mollusc fauna along an offshore-fjord gradient. Marine Ecology Progress Series 97:209224.

Bush KJ. 1898. Revision of the Marine Gastropods referred to Cyclostrema, Adeorbis, Vitrinella, and related genera; with description of some new genera and species belonging to the Atlantic Fauna of America. Transactions of the Connecticut Academy of Sciences 10:97-143.

Cachia C, Mifsud C, Sammut PM. 1996. The Marine Mollusca of the Maltese Islands (Part Two: Neotaenioglossa). Backhuys Publishers, Leiden. 228 pp.

Chaban EM. 2000. Some materials for revision of opisthobranchs of the family Retusidae (Mollusca: Cephalaspidea). Annual Reports of the Zoological Institute, Russian Academy of Sciences. [www.zin.ru/annrep/2000/04.html]

Christiaens J. 1973. Révision du genre Patella (Mollusca: Gastropoda). Bulletin Museum Nat Hist Natl 3:1305-1392.

Clemam (Check List of European Marine Mollusca). [www. somali.asso.fr/ clemam].

Dantart L, Luque A. 1994. Cocculiniformia and Lepetidae (Gastropoda: Archaeogastropoda) from Iberian waters. Journal of Molluscan Studies 60:277-313.

Dautzenberg P, Fischer H. 1912. Mollusques provenant des campagnes de l'Hirondelle et de la PrinCESSE-Alice dans les Mers du Nord. Résultats des Campagnes Scientifiques accomplies sur son Yacht par Albert I. 37:1-629.

Dons C. 1933. Norges strandfauna IV. Utbredelsen av Patella vulgata. Det Kongelige Norske Videnskabers Selskab Forhandlinger 6:185-188.

Dons C. 1949. Norges strandfauna XXXV. Fremgjellesnegler I. Det Kongelige Norske Videnskabers Selskab Forhandlinger 21:191-196.

Evertsen J, Bakken T. 2005. Nudibranch diversity (Gastropoda, Heterobranchia) along the coast of Norway. Fauna norvegica 25:1-37.

Fretter V, Graham A. 1981. The Prosobranch Molluscs of Britain and Denmark. Part six (pp. 285-362)-Cerithiacea etc. Journal of Molluscan Studies, Suppl. 9.

Fretter V, Graham A. 1985. The Prosobranch Molluscs of Britain and Denmark. Part eight (pp. 435-556) - Neogastropoda. Journal of Molluscan Studies, Suppl. 15.

Friele H. 1874. Oversigt over de i Bergens omegn forekommende skaldækte mollusker. Christiania Videnskabs-Selskabs Forhandlinger for 1873:1-24.

Friele H. 1876. Bidrag til Vestlandets molluskfauna. Christiania Videnskabs-Selskabs Forhandlinger for 1875:57-64.

Friele H. 1882. Mollusca I. The Norwegian North-Atlantic Expedition, 1876-1878

Friele H. 1886. Mollusca II. The Norwegian North-Atlantic Expedition, 1876-1878

Friele H. 1903. Mollusken der ersten Nordmeerfahrt des Fischereidampfers "Michael Sars" 1900 unter Leitung von Herrn Dr. Johan Hjort. Bergens Museums Aarbog 1902(3):1-18.

Friele H, Grieg J. 1901. Mollusca III. The Norwegian NorthAtlantic Expedition, 1876-1878 7(5):1-129.

Gianuzzi-Savelli R, Pusateri F, Palmeri A, Ebreo C. 1999. Atlante delle Conchiglie Marine del Mediterraneo, vol. three 
(CAenogastropoda parte 2: Ptenoglossa). "Evolver" srl, Roma. $127 \mathrm{pp}$.

Gofas S. 2005. Geographical differentiation in Clelandella (Gastropoda: Trochidae) in the northeastern Atlantic. Journal of Molluscan Studies 71:133-144.

Graham A. 1988. Molluscs: Prosobranch and Pyramidellid Gastropods. Synopses of the British Fauna (New Series) two (Second Edition):1-662.

Grieg J. 1914. Bidrag til kundskapen om Hardangerfjordens fauna. Bergens Museums Aarbok 1913 (1):1-147.

Grieg J. 1915. Evertebratfaunaen paa havdypet utenfor "Tampen". Bergens Museums Aarbok 1914 (3):1-26.

Gulbin VV, Golikov AN. 1997. A review of the Prosobranch family Velutinidae in cold and temperate waters of the Northern Hemisphere. I. Capulacmaeinae. Ophelia 47:43-54.

Gulbin VV, Golikov AN. 1998. A review of the Prosobranch family Velutinidae in cold and temperate waters of the Northern Hemisphere. II. Velutininae: genus Limneria. Ophelia 49:211220.

Gulbin VV, Golikov AN. 1999. A review of the Prosobranch family Velutinidae in cold and temperate waters of the Northern Hemisphere. III. Velutininae. Genera Ciliatovelutina and Velutina. Ophelia 51:223-238.

Gulbin VV, Golikov AN. 2000. A review of the Prosobranch family Velutinidae in cold and temperate waters of the Northern Hemisphere. IV. Velutininae. Genera Velutella, Cartilagovelutina and Marsenina. Ophelia 53:141-149.

Gulbin VV, Golikov AN. 2001. A review of the Prosobranch family Velutinidae in cold and temperate waters of the Northern Hemisphere. V. Onchidiopsinae. Ophelia 54:119-132.

Hansson HG. 1998. NEAT (North East Atlantic Taxa), Scandinavian marine Mollusca Check-List. Internet Ed., Aug. 1998. [www. tmbl.gu.se/libdb/taxon/taxa.html]

Hansson HG. 2003. Faktablad: Raphitoma purpurea (Montagu, 1903). ArtDatabanken 2003-09-10. Two pp.

Hansson HG. 2005. Faktablad: Anatoma crispata. ArtDatabanken 2005-05-11. Two pp.

Hansson HG. 2007. Faktablad: Patella vulgata, stor skålsnäcka. ArtDatabanken 2007-01-31. Two pp.

Høisæter T. 1968. Skenea nitens, Ammonicera rota, Odostomia lukisi, and Eulimella nitidissima, small marine gastropods new to the Norwegian fauna. Sarsia 31:25-34.

Høisæter T. 1986. An annotated check-list of marine molluscs of the Norwegian coast and adjacent waters. Sarsia 71:73-145.

Høisæter T. 1989. Biological notes on some Pyramidellidae (Gastropoda: Opisthobranchia) from Norway. Sarsia 74:283297.

Høisæter T. (submitted). Reinstatement of Cerithiella danielsseni (Gastropoda: Caenogastropoda: Cerithiopsidae): a species confined to negative temperatures in the Norwegian Sea.

Høisæter T, Johannessen PJ. 2001. Xylodiscula planata sp. nov., a 'lower' heterobranch gastropod from Norwegian waters. Sarsia 86:325-332.

Høisæter T, Sneli J-A, Wikander PB, Brattegard T. 1997a. Subclass Prosobranchia (phylum Mollusca) prosobranchs (snails, limpets and whelks) (forgjellesnegler) Pp. 233-246 in: Brattegard T, Holthe T. (eds). Distribution of marine, benthic macro-organisms in Norway. A tabulated catalogue. Research Report for DN (Directorate for Nature Management), 1997-1. 409 pp.
Høisæter T, Sneli J-A, Brattegard T. 1997b. Subclass Heterobranchia (phylum Mollusca) non-prosobranch gastropods, includes shelled opisthobranchs and sea slugs (bakgjellesnegler). Pp. $247-$ 258 in: Brattegard T. \& T. Holthe (eds) Distribution of marine, benthic macro-organisms in Norway. A tabulated catalogue. Research Report for DN (Directorate for Nature Management), 1997-1. 409 pp.

Horikoshi M. 1967. Reproduction, larval features and life history of Philine denticulata (J. Adams) (Mollusca Tectibranchia). Ophelia 4:43-84.

Houart R. 1981. Révision des Trophoninae d'Europe. Informations de la Société belge de Malacologie 9:2-70.

Hubendick B, Warén A. 1971. Småsnäckor från Svenska Västkusten 3. Släktena Cingula, Capulacmaea, Homalogyra, Caecum, Nassarius m.fl. Göteborgs Naturhistoriska Museum, Årstryck 1971: 43-49.

Hubendick B, Warén A. 1973. Småsnäckor från Svenska Västkusten 5. Släktena Eulima, Balcis, Mangelia, Clathrus m.fl. Göteborgs Naturhistoriska Museum, Årstryck 1973: 41-48.

Hubendick B, Warén A. 1976. Framgälade Snäckor från Svenska Västkusten. Göteborg. 73 pp.

Jeffreys J.G. 1864. British Conchology. Vol. 2. Marine Shells. John van Voorst, London. 465 pp.

Hubendick B, Warén A. 1867. British Conchology. Vol. 4. Marine Shells. John van Voorst, London. 486 pp.

Hubendick B, Warén A. 1870. Norwegian Mollusca. Annals and Magazine of Natural History, Ser. 4, 5:438-448.

Hubendick B, Warén A. 1883. On the Mollusca procured during the 'Lightning' and 'Porcupine' expeditions, 1868-70. (Part V). Proceedings of the Zoological Society of London 1882:656687.

Kabat AR. 1991. The classification of Naticidae (Mollusca: Gastropoda): Review and analysis of the supraspecific taxa. Bulletin of the Museum of Comparative Zoology 152:417-449.

Killeen IJ, Smith SM. 1992. Aclis gulsonae and other new marine records from Dunstaffnage Channel and Loch Etive. Journal of Conchology 34:257.

Kolstad K. 1959. Patella aspera Lamarck, New to Norway. Nature 1884: 1886

Kool SP. 1993. The systematic position of the genus Nucella (Prosobranchia: Muricidae: Ocenebrinae). Nautilus 107: 4357.

Koufopanou V, Reid DG, Ridgway SA, Thomas RH. 1999. A Molecular Phylogeny of the Patellid Limpets (Gastropoda: Patellidae) and its Implications for the Origins of Their Antitropical Distribution. Molecular Phylogentics and Evolution 11:138-156.

Kristensen JH. 1970. Fauna associated with the sipunculid Phascolion strombi (Montagu), especially the parasitic gastropod Menestho diaphana (Jeffreys). Ophelia 7:257-276.

Lemche H. 1948. Northern and arctic Tectibranch Gastropods. I. The larval shells. II. A revision of the cephalaspid species. Kongelige Danske Videnskabernes Selskab, Biologiske Skrifter 5(3):1-136.

Lemche H. 1967. Rhinodiaphana g.n. ventricosa (JEFFREYS, 1865) redescribed (Gastropoda, Tectibranchiata). - Sarsia 29:207-214.

Lewis JR, Tambs-Lyche H. 1962. Littorina neritoides in Scandinavia. Sarsia 7:7-10.

Linden J van der. 1994. Philine intricata Monterosato, 1884, 
an overlooked species from the North-East Atlantic and the Mediterranean Sea (Gastropoda, Opisthobranchia: Philinidae). Basteria 58:41-48.

Linden J van der. 1995. Philinidae dredged by the CANCAP expeditions (Gastropoda, Opisthobranchia). Basteria 59:65-83.

Lundberg J, Schander C, Stokland Ø. 1996. A preliminary cladistic analysis of North Atlantic Oenopota Moerch, 1852 and Propebela Iredale, 1918 (Gastropoda: Conoidea) Journal of Molluscan Studies 62:289-298

Lützen J. 1979. Studies on the life history of Enteroxenos Bonnevie, a gastropod endoparasitic in aspidochirote Holothurians. Ophelia 18:1-51.

Marshall BA. 1978. Cerithiopsidae (Mollusca: Gastropoda) of New Zealand, and a provisional classification of the family. New Zealand Journal of Zoology 5:47-120.

Micali P, Nofroni I, Aartsen JJ van. 1993. Addition to the knowledge of the European Chrysallida species, with notes on a recent work by Van der Linden \& Eikenboom (Gastropoda, Opisthobranchia). Basteria 57:147-154.

Moen FE, Svensen E. 2003. Dyreliv i havet. Nordeuropeisk marin fauna. 3. utgave. KOM Forlag, Kristiansund. 608 pp.

Nakano T, Ozawa T. 2004. Phylogeny and historical biogeography of limpets of the order Patellogastropoda based on mitochondrial DNA sequences. Journal of Molluscan Studies 70:31-41.

Nakano T, Ozawa T. 2007. Worldwide phylogeography of limpets of the order Patellogastropoda: molecular, morphological and paleontological evidence. Journal of Molluscan Studies 73:7999.

Næs K, Oug E, Knutzen J. 1998. Source and Species-dependent Accumulation of Polycyclic Aromatic Hydrocarbons (PAHs) in Littoral Indicator Organisms from Norwegian Smelter-affected Marine Waters. Marine Environmental Research 45:193-207.

Nordgaard O. 1913. Foraminiferer og mollusker fra de vestlandske fjorde. Kongelige Norske Videnskabers Selskabs Skrifter 1912(11):1-23.

Nordgaard O. 1915. Havstrømmene og den norske marine fauna. Kongelige Norske Videnskabers Selskabs Skrifter 1914(5):1-34.

Nordgaard O. 1918. Buccinum hydrophanum Hanck. A high-arctic relict in the Trondhjem Fjord. Kongelige Norske Videnskabers Selskabs Skrifter 1917(3):1-6.

Norman AM. 1879. The mollusca of the fiords near Bergen, Norway. Journal of Conchology 2:8-77.

Norman AM. 1893. A month on the Trondhjem Fiord. Annals and Magazine of Natural History Ser. 6, 12:341-361 \& 472-486.

Norman AM. 1902. Notes on the natural history of East Finmark (Mollusca). Annals and Magazine of Natural History Ser. 7, 10:341-367.

Odhner NH. 1907. Northern and Arctic invertebrates in the collection of the Swedish State Museum. III. Opisthobranchia and Pteropoda. Kungliga Svenska Vetenskapsakademiens Handlingar 41(4):1-114.

Odhner NH. 1912. Northern and Arctic invertebrates in the collection of the Swedish State Museum. V. Prosobranchia. 1 Diotocardia. Kungliga Svenska Vetenskapsakademiens Handlingar 48(1):1-93.

Odhner NH. 1913. Northern and Arctic invertebrates in the collection of the Swedish State Museum. VI. Prosobranchia. two Semiproboscidifera. Kungliga Svenska Vetenskapsakademiens Handlingar 50(5):1-89.
Odhner NH. 1915. Die Molluskenfauna des Eisfjordes. Kungliga Svenska Vetenskapsakademiens Handlingar 54(1):1-274.

Odhner NH. 1926. Nudibranchs and Lamellariids from the Trondhjem Fjord. Kongelige Norske Videnskabers Selskabs Skrifter 1926(2):1-36.

Odhner NH. 1939. Opisthobranchiate Mollusca from the western and northern coasts of Norway. Kongelige Norske Videnskabers Selskabs Skrifter 1939(1):1-92.

Olesen M. (red.) 2005. Naturforholdene i havet omkring Læsø. Pilotprojekt Marin Nationalpark Læsø. [http://www.mbl.ku.dk/ molesen/L\%C3\%A6s\%C3\%B8\%20 rapport13.pdf]

Opinion 1700. 1991. Laeochochlis Dunker \& Metzger, 1874, Jahrbücher der Deutschen Malakozoologischen Gesellschaft, 1(2): 146, ruled under the plenary power to be an incorrect original spelling of Laeocochlis (Gastropoda). Op. 1700 of ICZN. Bulletin of Zoological Nomenclature 48 (?)

Peñas A, Rolán E. 1998. La familia Pyramidellidae Gray, 1840 (Mollusca, Gastropoda, Heterostropha) en África Occidental. 3. El género Chrysallida s.l. Iberus, Supplemento 4:1-73.

Platts E. 1985. An annotated list of the north Atlantic Opisthobranchia. Ophelia, Supplementum 2:150-170.

Ponder WF. 1985. A review of the genera of the Rissoidae (Mollusca: Mesogastropoda: Rissoacea). Records of the Australian Museum, Supplement 4:1-221.

Ponder WF. 1990. The anatomy and relationships of the Orbitestellidae (Gastropoda: Heterobranchia). Journal of Molluscan Studies 56:515-532.

Rehder HA. 1990. Clarification of the identity of the snail Margarites groenlandicus (Gmelin, 1791) (Gastropoda: Trochidae). The Nautilus 103:117-123.

Reid DG. 1996. Systematics and Evolution of Littorina. Ray Society, London. 463 pp.

Ridgway SA, Reid DG, Taylor JD, Branch GM, Hodgson, AN. 1998. A cladistic phylogeny of the family Patellidae (Mollusca: Gastropoda). Philosophical Transactions of the Royal Society of London, Series B 353:1645-1671.

Rodriguez Babio C, Thiriot-Quiévreux C. 1974. Gastéropodes de la Région de Roscoff. Étude particulière de la protoconque. Cahiers de Biologie Marine 15:531-549.

Rodriguez Babio C, Thiriot-Quiévreux C. 1975. Pyramidellidae, Philinidae et Retusidae de la Région de Roscoff. Étude particulière des protoconques de quelques espèces. Cahiers de Biologie Marine 16:83-96.

Rolán E, Luque AA. 1994. Nassarius reticulatus (Linnaeus, 1758) y Nassarius nitidus (Jeffreys, 1867) (Gastropoda, Nassariidae), dos especies válidas de los mares de Europa. Iberus 12:59-76.

Rosenberg G. 2005. Malacolog 4.1.0: A Database of Western Atlantic Marine Mollusca [http://www.malacolog.org/].

Sá-Pinto A, Branco M, James Harris D, Alexandrino P. 2005. Phylogeny and phylogeography of the genus Patella based on mitochondrial DNA sequence data. Journal of Experimental Marine Biology and Ecology 325:95-110.

Sabelli B, Gianuzzi-Savelli R, Bedulli D. 1990. Catalogo Annotato dei Molluschi Marini del Mediterraneo, vol. 1. Edizioni Libreria Naturalistica Bolognese. 348 pp.

Sabelli B, Gianuzzi-Savelli R, Bedulli D. 1992. Catalogo Annotato dei Molluschi Marini del Mediterraneo, vol. 2. Edizioni Libreria Naturalistica Bolognese: 349-498.

Sanjuan A, Pérez-Losada M, Rolán E. 1997. Allozyme evidence 
for cryptic speciation in sympatric populations of Nassarius spp. (Mollusca: Gastropoda). Journal of the Marine Biological Asssociation of the United Kingdom 77:773-784.

Sars GO. 1878. Bidrag til Kundskaben om Norges arktiske Fauna. I. Mollusca Regionis Arcticae Norvegiae. Oversigt over de i Norges arktiske region forekommende bløddyr. Universitetsprogram for første halvaar 1878. Christiania. $466 \mathrm{pp}$.

Schander C. 1995. Pyramidellidae (Mollusca, Gastropoda, Heterobranchia) of the Faroe Islands. Sarsia 80:55-65.

Schiøtte T. 1998. A taxonomic revision of the genus Diaphana Brown, 1827, including a discussion of the phylogeny and zoogeography of the genus (Mollusca: Opisthobranchia). Steenstrupia 24:77-140

Schiøtte T, Warén A. 1992. An annotated and illustrated list of the types of Mollusca described by H.P.C. Møller from West Greenland. Meddelelser om Grønland, Bioscience 35 - 1992:134.

Schneider JS. 1885-1886. Undersøgelser af dyrelivet i de arktiske fjorde. III. Tromsøsundets molluskfauna. Tromsø Museums Aarshefter 8:45-112 \& 9:1-50.

Schneider JS. 1897. Fortsatte bidrag til kundskaben om Tromsøsundets molluskfauna. - Tromsø Museums Aarshefter 18:101-106.

Simpson J. 1910. Notes on some rare Mollusca from the North Sea and Shetland-Faeroe Channel. Journal of Conchology 13:109115.

Sjøtun K. 1997. A new observation of Crepidula fornicata (Prosobranchia, Calyptraeidae) in western Norway. Sarsia 82:275-276.

Smith SM, Heppell D. 1991. Checklist of British marine Mollusca. National Museums of Scotland Information Series 11:1-114.

Sneli JA. 1968. Pelikanfotsneglen, Aporrhais serresiana, langs Norges sydøstkyst. Fauna (Oslo) 21:193-194.

Sneli JA. 1974. A collection of marine Mollusca from Møre and Romsdal, Northwestern Norway. Kongelige Norske Videnskabers selskab Museet, Miscellanea 20:1-17.

Sneli JA. 1979. Prosobranchia from Sognefjorden, Western Norway. Sarsia 64:259-267.

Sneli JA, Gulliksen B. 2006. Prosobranch Molluscs and Ascidians in the Trondheimsfjord. Zoologisk Rapport 2006-1, NTNU, Vitenskapsmuseet.

Sneli JA, Schiøtte T, Jensen KR, Wikander PB, Stokland Ø. Sørensen J. 2005. The Marine Mollusca of the Faroes. Annales Societatis Scientiarum Færoensis Supplementum XXXXII: 15-176.

Soot-Ryen T. 1951. New records of the distribution of marine Mollusca in Northern Norway. Astarte 1:1-5.

Stokland Ø. 1981. Prosobranchgruppen Bela auct i Grønlandske og nordlige Nordøstatlantiske farvann. Cand. scient.-thesis in zoology, University of Trondheim.

Thompson TE. 1988. Molluscs: Benthic Opistobranchs (Mollusca: Gastropoda). Synopses of the British Fauna (New Series) eight (Second Edition):1-356.

Vader W. 1972. Nordgrensen for albueskjell, Patella vulgata, i Finnmark. Fauna (Oslo) 25:77-78

Vader W. 1975. Range extension of Patella vulgata (Mollusca, Prosobranchia) on the island of Skjervøy, northern Norway, between 1933 and 1973. Astarte 8:49-51.

Vassenden G,HeggøyE,JohannessenP.2007.Resipientundersøkelse i Vindafjord kommune i 2006. VestBio, Report from the Department of Biology, University of Bergen. two (2007). 51 pp.

Warén A. 1972a. On the systematic position of Fissurisepta granulosa JefFreYs, 1882 and Patella laterocompressa De RAYNEVAL \& PonZI, 1854 (Gastropoda Prosobranchia). Sarsia 51:17-24.

Warén A. 1972b. Cingula globuloides sp.n. (Gastropoda, Prosobranchia) from Northern Atlantic. Zoologica Scripta 1:191192.

Warén A. 1973. Revision of the Rissoidae from the Norwegian North Atlantic Expedition 1876-78. Sarsia 53:1-14.

Warén A. 1974. Revision of the Arctic-Atlantic Rissoidae (Gastropoda, Prosobranchia). Zoologica Scripta 3:121-135.

Warén A. 1988. The identity of Turbo politus Linnaeus, 1758 (Prosobranchia, Eulimidae). Bolletino Malacologico 24:17-24.

Warén A. 1989a. New and little known mollusca from Iceland. Sarsia 74:1-28.

Warén A. 1989b. Designation of neotypes of 'Melanella alba (Da Costa, 1778)' and 'Eulima glabra (Da Costa, 1778)' (Prosobranchia). Journal of Conchology 33:219-224.

Warén A. 1991. New and little known Mollusca from Iceland and Scandinavia. Sarsia 76:53-124.

Warén A. 1992. New and little known "Skeneimorph" gastropods from the Mediterranean Sea and the adjacent Atlantic Ocean. Bollettino Malacologico 27:149-248.

Warén A. 1993. New and little known Mollusca from Iceland and Scandinavia. Part 2. Sarsia 78:159-201.

Warén A. 1996a. New and little known Mollusca from Iceland and Scandinavia. Part 3. Sarsia 81:197-245.

Warén A. 1996b. Ecology and systematics of the North European species of Rissoa and Pusillina (Prosobranchia: Rissoidae). Journal of the Marine Biological Asssociation of the United Kingdom 76:1013-1059.

Warén A, Smith SM. 2006. A new North Atlantic species of Beringius, (Gastropoda: Buccinidae) with comments on B. turtoni. Journal of Conchology 39:185-192.

Watters GT. 2007. Trophoninae in: digital Murex [http://www. biosci.ohio-state.edu/ molluscs/test3/trophoninae.html]

Weber LI, Hawkins SJ. 2005. Patella aspera and P. ulyssiponensis: genetic evidence of speciation in the North-east Atlantic. Marine Biology 147:153-162

Wikander PB. 1989. Inventering av molluskfaunaen på Skagerrakkysten I. NIVA-Rapport O-88221. 195 pp.

Wikander PB. 1990. Inventering av molluskfaunaen på Skagerrakkysten II. NIVA-Rapport O-89119. 274 pp.

Wilke T, Rolán E, Davis GM. 2000. The mudsnail genus Hydrobia s.s. in the northern Atlantic and western Mediterranean: a phylogenetic hypothesis. Marine Biology 137:827-833.

Ziegelmeier E. 1966. Die Schnecken der deutschen Meeresgebiete und brackigen Kustengewasser. Helgoländer Wissenchaftliche Meeresuntersuchungen, 13:1-61. 


\section{INDEX OF SCIENTIFIC NAMES}

Aartsenia candida (Møller, 1842) ............................................ 68

Acirsa coarctata (Jeffreys, 1884) .............................................. 34

Aclis ascaris (Turton, 1819)................................................... 33

Aclis minor (Brown, 1827) ...................................................... 33

Aclis sarsi Dautzenberg \& H. Fischer, 1912 ........................... 33

Aclis walleri (Jeffreys, 1867)................................................ 34

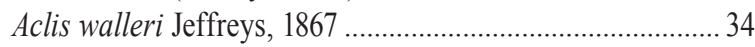

Acmaea testudinalis (Müller, 1776) .......................................18

Acmaea virginea (Müller, 1776).............................................18

Acmaea rubella (Fabricius, 1780) ...........................................18

Acteon tornatilis (Linné, 1758)............................................ 78

Adeorbis supranitidus S. Wood, 1848 .................................... 46

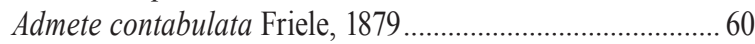

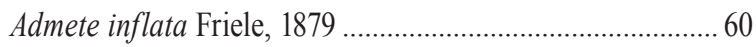

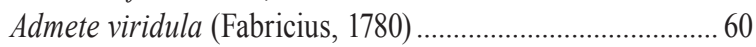

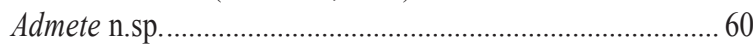

Akera bullata O.F. Müller, 1776 .............................................. 83

Akritogyra helicella Warén, 1993 .......................................... 29

Alvania abyssicola (Forbes, 1850)......................................... 42

Alvania beani (Hanley in Thorpe, 1844) ................................ 40

Alvania beanii (Thorpe, 1844 ex Hanley MS)....................... 40

Alvania cf. scrobiculata (Møller, 1842) ............................... 42

Alvania cimicoides (Forbes, 1844) ...........................................41

Alvania incognita Warén, 1996 ..............................................41

Alvania jeffreysi (Waller, 1864) .............................................41

Alvania mighelsi (Stimpson, 1851) ........................................ 44

Alvania aff. moerchi (Collin, 1886) ......................................41

Alvania moerchi (Collin, 1886) .............................................41

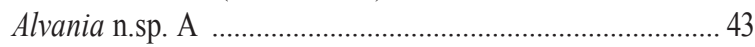

Alvania pseudosyngenes (Warén, 1973) ..................................41

Alvania punctura (Montagu, 1803) ........................................41

Alvania (Crisilla) semistriata (Montagu, 1808).................... 43

Alvania subsoluta (Aradas, 1847) ......................................... 42

Alvania testae (Aradas \& Maggiore, 1844) ........................... 42

Alvania verrilli (Friele, 1886)............................................... 42

Alvania wyvillethomsoni (Friele, 1877)................................ 42

Alvania zetlandica (Montagu, 1815) ..................................... 42

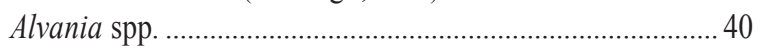

Amauropsis islandica (Gmelin, 1791) .................................... 51

Ammonicera rota (Forbes \& Hanley, 1850) ............................ 68

Amphissa acutecostata (Philippi, 1844)................................ 59

Anachis haliaeeti (Jeffreys, 1876)......................................... 59

Anatoma aspera (Philippi, 1844) ........................................... 20

Anatoma crispata (Fleming, 1828) ................................ 20, 21

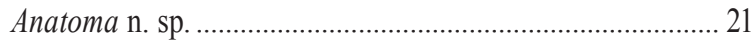

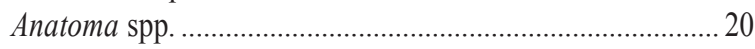

Anatoma umbilicata (Jeffreys, 1883).................................... 21

Anekes undulisculpta Bouchet \& Warén, 1979 .................... 29

Ansates pellucida (Linné, 1758) ...............................................18

Aplysia punctata Cuvier, 1803 .............................................. 83

Aporrhais pespelecani (Linné, 1758)..................................... 46
Aporrhais serresianus (Michaud, 1828) .................................. 46

Astyris rosacea (Gould, 1840)............................................. 59

Bacteridium cf. carinatum (de Folin, 1870).......................... 76

Bathycrinicola curta (Warén, 1972).......................................... 35

Bela brachystoma (Philippi, 1844)........................................ 63

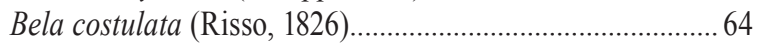

Bela nebula (Montagu, 1803)................................................. 64

Bela powisiana (Dautzenberg, 1887) ........................................ 64

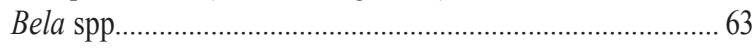

Beringius ossiania (Friele, 1879) .......................................... 55

Beringius turtoni (Bean, 1834).............................................. 55

Bittium reticulatum (da Costa, 1778) ................................... 30

Boreocingula castanea (Møller, 1842)................................... 43

Boreocingula globuloides (Warén, 1972) ............................... 45

Boreotrophon clathratus (Linné, 1767) ............................... 52

Boreotrophon clavatus (G.O. Sars, 1878) .............................. 53

Boreotrophon truncatus (Strøm, 1768) ................................ 53

Brachystomia Monerosato, 1884........................................... 71

Buccinum cyaneum Bruguière, 1792 ..................................... 54

Buccinum finmarchianum Verkrüzen, 1875 ........................... 54

Buccinum finmarkianum Verkrüzen, 1875 ............................ 54

Buccinum humphreysianum Bennett, 1824 ............................ 54

Buccinum hydrophanum Hancock, 1846 ................................ 54

Buccinum kjennerudae Bouchet \& Warén, 1985.................. 54

Buccinum nivale Friele, 1882 .............................................. 54

Buccinum oblitum Sykes, 1911 .............................................. 54

Buccinum scalariforme Møller, 1842.................................... 55

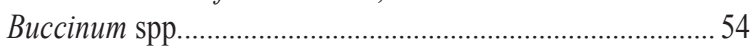

Buccinum sulcatum Friele, 1882, not Born, 1778 ................. 54

Buccinum tumidulum G.O. Sars, 1878 .................................. 55

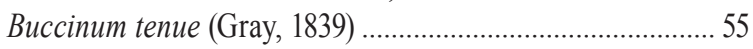

Buccinum undatum Linné, 1758 ........................................... 55

Buccinum undulatum Møller, 1842...................................... 54

Bulbus smithi (Brown, 1839) ............................................... 51

Bulla (= Utriculopsis) vitrea M. Sars, 1866 .......................... 81

Caecum glabrum (Montagu, 1803) ....................................... 45

Calliostoma formosa (McAndrews \& Forbes, 1847)............ 24

Calliostoma occidentale (Mighels \& Adams, 1842)............. 24

Calliostoma zizyphinus (Linné, 1758).................................. 24

Calyptoconcha pellucida (Verrill, 1880................................ 49

Calyptoconcha cf. pellucida (Verrill, 1880) .......................... 49

Capulus radiatus M. Sars, 1851 .............................................. 49

Capulacmaea radiata (M. Sars, 1851) ................................... 49

Capulus ungaricus (Linné, 1758).......................................... 47

Ceratia proxima (Forbes \& Hanley, 1850)............................. 46

Cerithiella metula (Lovén, 1846)............................................ 32

Cerithiopsis barleei Jeffreys, 1867...........................................31

Cerithiopsis tubercularis (Montagu, 1803)..............................31

Chasteria danielsseni (Friele, 1877) ...................................... 32

Cheirodonta pallescens (Jeffreys, 1867).................................31

Chrysallida bjoernssoni Warén, 1991 .................................... 69

Chrysallida brattstroemi Warén, 1991.................................. 69

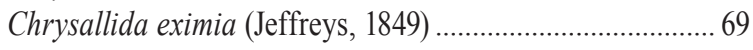

Chrysallida hoeisaeteri Warén, 1991..................................... 69 
Chrysallida indistincta (Montagu, 1808).

Chrysallida interstincta (J. Adams, 1797). 69

Chrysallida nivosa (Montagu, 1803).

Chrysallida obtusa (Brown, 1827)......

Chrysallida pellucida (Dillwyn, 1817)......

Chrysallida sarsi (Nordsick, 1972).....

Chrysallida spiralis (Montagu, 1803)

Chrysallida sublustris (Friele, 1886) ...

Chrysallida truncatula (Jeffreys, 1850)

Ciliatovelutina Golikov \& Gulbin, 1990.

Cima cuticulata Warén, 1993.

Cima cf. cuticulata Warén, 1993

Cima inconspicua Warén, 1993

Cima minima (Jeffreys, 1858).....

Cingula globuloides (Warén, 1972)

Cingula trifasciata (J. Adams, 1800)...

Circulus pseudopraecedens Adam \& Knudsen, 1969....... 43

Circulus sarsi (Bush, 1898)

Clelandella miliaris (Brocchi, 1814)

Colobocephalus costellatus M. Sars, 1870 ........................... 78

Colpodaspis pusilla M. Sars, 1870....................................... 78

Colus (Colicryptus) fenestratus (Turton, 1834) ..................... 57

Colus (Siphonorbis) ebur sensu Friele (1877)....................... 58

Colus (Siphonorbis) sarsii (Jeffreys, 1869)........................... 58

Colus (Turrisipho) dalli (Friele, 1882) ................................. 57

Colus (Turrisipho) lachesis (Mørch, 1869) ........................... 57

Colus (Turrisipho) undulatus (Friele in Tryon, 1881)........... 57

Colus ebur (Mørch, 1869) ...................................................... 56

Colus glaber (Kobelt, 1876) ................................................. 55

Colus gracilis (da Costa, 1778) ............................................. 55

Colus holboelli (Møller, 1842) ............................................... 55

Colus islandicus (Gmelin, 1791) ............................................ 55

Colus islandicus (Mohr, 1786) .............................................. 55

Colus jeffreysianus (P. Fischer, 1868) .................................... 55

Colus latericeus (Møller, 1842)............................................. 56

Colus sabini (J.E. Gray, 1824)................................................ 56

Colus tortuosus (Reeve, 1855) ............................................... 55

Colus turgidulus (Friele, 1877) ............................................... 56

Colus verkruezeni (Kobelt, 1876) .......................................... 56

Crepidula fornicata (Linné, 1758) ......................................... 47

Crinolamia dahli Bouchet \& Warén, 1979 ............................ 35

Crisilla semistriata (Montagu, 1808).................................... 43

Cryptonatica affinis (Gmelin, 1791) ...................................... 50

Cryptonatica bathybii (Friele, 1879) ..................................... 50

Curtitoma Bartsch, 1941 ......................................................... 61

Curveulima macrophthalmica (Warén, 1972) ....................... 35

Cyclostoma delicata Philippi, 1844 ...................................... 47

Cyclostrema willei Friele, 1886 ........................................... 28

Cylichna alba (Brown, 1827) .............................................. 82

Cylichna cylindracea (Pennant, 1777) .................................. 82

Cylichna lemchei Bouchet \& Warén, 1979 ........................... 82

Cylichna occulta (Mighels \& Adams, 1842) ........................ 82

Cylichnina nitidula (Lovén, 1846) ....................................... 79

Cylichnina umbilicata (Montagu, 1803) .............................. 79
Cylichnium africanum (Locard, 1897)................................ 79

Danilia otaviana (Cantraine, 1835)....................................... 24

Danilia tinei (Calcara, 1839) ................................................... 24

Diaphana globosa (Lovén, 1846) ........................................... 78

Diaphana hiemalis (Couthouy, 1839).................................... 78

Diaphana lactea (Jeffreys, 1877) .......................................... 78

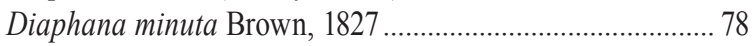

Dikoleps nitens (Philippi, 1844)............................................. 29

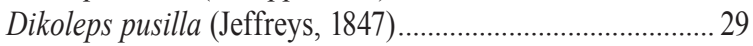

Ebala nitidissima (Montagu, 1803)........................................ 77

Ebala trigonostoma (de Folin, 1870)..................................... 76

Elachisina globuloides (Warén, 1972) ................................... 45

Emarginula crassa J. Sowerby, 1813 .................................... 19

Emarginula fissura (Linné, 1758) ........................................ 20

Emarginula fissura (Linné, 1767)...................................... 20

Enteroxenos oestergreni Bonnevie, 1902 ............................ 35

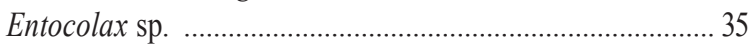

Epitonium clathratulum (Kanmacher, 1798).......................... 34

Epitonium clathrus (Linné, 1758).......................................... 34

Epitonium greenlandicum (Perry, 1811) ................................ 34

Epitonium trevelyanum (Johnston, 1841).............................. 34

Epitonium turtonis (Turton, 1819)........................................... 34

Erato voluta (Montagu, 1803) ................................................... 50

Erginus rubellus (O. Fabricius, 1780) ....................................18

Eudaronia aperta (Sykes, 1925) .............................................29

Eulima bilineata Alder, 1848 ................................................. 35

Eulima intermedia Cantraine, 1835 ...................................... 36

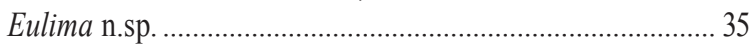

Eulima polita (Linné, 1758).................................................. 36

Eulimella acicula (Philippi, 1836)........................................ 70

Eulimella ataktos Warén, 1991................................................ 71

Eulimella compactilis (Jeffreys) G.O. Sars, 1878 ................. 71

Eulimella 'compactilis' (sensu G.O. Sars, 1878)................... 71

Eulimella gracilis Jeffreys, 1847.......................................... 71

Eulimella laevis (Brown, 1827)............................................. 70

Eulimella n. sp. A ..................................................................... 71

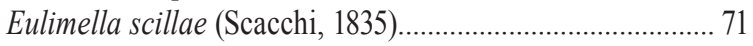

Eulimella ventricosa (Forbes, 1844) ............................. 70, 71

Eulimidae H. \& A. Adams, 1853 .......................................... 34

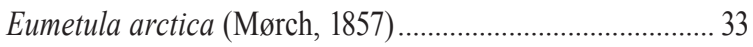

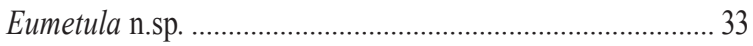

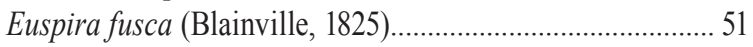

Euspira montagui (Forbes, 1838) ............................................ 51

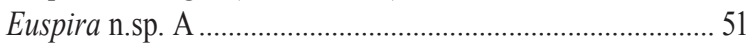

Euspira pallida (Broderip \& G.B. Sowerby I, 1829)............ 51

Euspira pulchella (Risso, 1826) ............................................ 51

Euspira spp. ..................................................................... 50

Fissurisepta granulosa Jeffreys, 1883 ................................. 20

Frigidoalvania janmayeni (Friele, 1878) ............................. 43

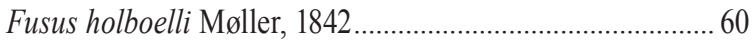

Gibbula cineraria (Linné, 1758) .......................................... 22

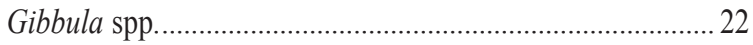

Gibbula tumida (Montagu, 1803) ......................................... 22

Graphis albida (Kanmacher, 1798)...................................... 77 


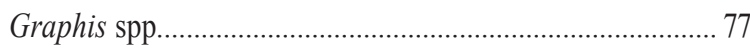

Gregorioiscala sarsi (Kobelt, 1904) ..................................... 34

Haedropleura septangularis (Montagu, 1803) ...................... 68

Haliella martynjordani sensu Hubendick \& Warén, 1973 ... 35

Haliella stenostoma (Jeffreys, 1858) ...................................... 35

Halielloides nitidus (Verrill, 1884) ....................................... 35

Halielloides ingolfiana Bouchet \& Warén, 1986 ................... 35

Haloceras aff. laxa (Jeffreys, 1885)...................................... 47

Hemiaclis glabra G.O. Sars, 1878 ........................................ 36

Hemiaclis ventrosa (Friele, 1876 ex Jeffreys MS)................. 36

Hemiaclis ventrosus (Friele, 1876)........................................ 36

Hinia incrassata (Strøm, 1868) ............................................. 58

Hinia pygmaea (Lamarck, 1822)............................................. 59

Hinia reticulata (Linné, 1758).............................................. 58

Hyala vitrea (Montagu, 1803) ................................................ 46

Hydrobia acuta (Draparnaud, 1805)....................................... 45

Hydrobia minuta sensu G.O. Sars.......................................... 45

Hydrobia neglecta Muus, 1963 .............................................. 45

Hydrobia ulvae (Pennant, 1777)............................................. 45

Hydrobia ventrosa (Montagu, 1803)....................................... 46

Iothia fulva (O.F. Müller, 1776)............................................. 19

Iothia cf. fulva (O.F. Müller, 1776)........................................ 19

Iphinopsis inflata (Friele, 1879) ............................................. 60

Johania cf. retifera (Forbes, 1844)......................................... 79

Jujubinus clelandi (W. Wood, 1828).................................... 22

Krachia cossmanni (Dautzenberg \& H. Fischer 1896)......... 32

Lacuna crassior (Montagu, 1803)......................................... 38

Lacuna pallidula (da Costa, 1778) ....................................... 38

Lacuna parva (da Costa, 1778) ............................................. 38

Lacuna vincta (Montagu, 1803) ........................................... 38

Laeocochlis macandreae (H. Adams, 1858)......................... 32

Laeocochlis sinistratus (Nyst, 1835).................................... 32

Lamellaria latens (O.F. Müller, 1776).................................... 49

Lamellaria pellucida Verrill in Verrill \& Smith, 1882 ........ 49

Lamellaria perspicua (Linné, 1758)...................................... 49

Laona finmarchica (M. Sars, 1858) ...................................... 80

Laona flexuosa (M. Sars, 1870) ............................................... 80

Laona pruinosa (W. Clark, 1827) .......................................... 80

Lepeta caeca (O.F. Müller, 1776) ........................................... 19

Lepetella laterocompressa (de Rayneval \& Ponzi, 1854) .... 21

Lepetella sierrai Dantart \& Luque, 1994............................... 22

Lepetella tubicola Verrill \& Smith, 1880 ................................ 22

Limneria undata (J. Smith, 1839).......................................... 49

Liomesus eburneum (G.O. Sars, 1878)................................... 56

Liomesus ovum (Turton, 1825).............................................. 56

Liostomia afzelii Warén, 1991 ............................................... 74

Liostomia clavula (Lovén, 1846) ............................................. 74

Liostomia eburnea (Stimpson, 1851)..................................... 74

Liostomia hansgei Warén, 1991 ............................................. 74

Lissotesta turrita (Gaglini, 1987).......................................... 29

Littorina arcana Hannaford Ellis, 1978................................ 37

Littorina compressa Jeffreys, 1865 ........................................ 37

Littorina fabalis (Turton, 1825).............................................. 37

Littorina littorea (Linné, 1758) ............................................. 38
Littorina mariae Sacchi \& Rastelli, 1966................................ 37

Littorina neglecta Bean, 1844 .............................................. 38

Littorina neritoides (Linné, 1758) ............................................ 38

Littorina obtusata (Linné, 1758) ............................................ 38

Littorina palliata (Say, 1822).................................................. 38

Littorina saxatilis (Olivi, 1792) .......................................37, 38

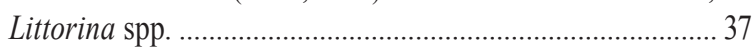

Lunatia alderi (Forbes, 1838)................................................ 51

Lunatia montagui (Forbes, 1838) ......................................... 51

Lunatia nana (Møller, 1842) ............................................... 52

Lunatia pallida (Broderip \& G.B. Sowerby I, 1829) ............ 51

Mangelia attenuata (Montagu, 1803) .................................... 64

Mangelia brachystoma (Philippi, 1844).................................. 63

Mangelia coarctata (Forbes, 1840)....................................... 64

Mangelia costulata (Risso, 1826) ..................................................

Mangelia holboelli Møller, 1842 ............................................ 60

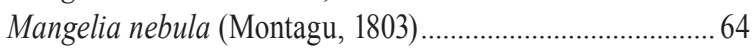

Mangelia striolata (Philippi)........................................................ 64

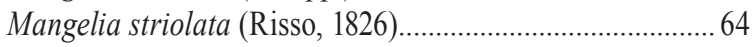

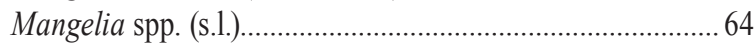

Manzonia crassa (Kanmacher, 1798) ..................................... 43

Manzonia zetlandica (Montagu, 1815) .................................. 42

Margarites costalis (Gould, 1841)......................................... 23

Margarites groenlandica (Gmelin, 1791) .............................. 23

Margarites groenlandicus (Gmelin, 1791)............................ 23

Margarites helicina (Phipps, 1774)....................................... 23

Margarites helicinus ............................................................... 23

Margarites olivacea (Brown, 1827)..................................... 23

Margarites striata (Leach, 1819) .......................................... 23

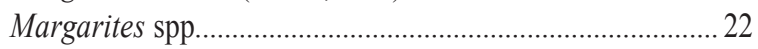

Marseniella borealis Bergh, 1886........................................50

Marsenina glabra (Couthouy, 1839) ............................................ 50

Marshallora adversa (Montagu, 1803) .................................. 30

Megastomia Monterosato, 1884 ........................................... 71

Melanella alba (da Costa, 1778)............................................. 36

Melanella cf. polita (Linné, 1758)......................................... 37

Melanella curta (Warén, 1972) ............................................... 35

Melanella frielei (Jordan, 1895) ............................................. 36

Melanella laurae (Friele, 1886)............................................ 36

Melanella lubrica (Monterosato, 1890)................................... 36

Melanella monterosatoi (Monterosato, 1890)......................... 37

Melanella orphanensis Clarke, 1974...................................... 37

Melanella platyacme sensu Hubendick \& Warén 1976........ 37

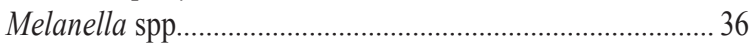

Melanela turrita Bouchet \& Warén, 1986 ............................... 37

Melarhaphe neritoides (Linné, 1758)..................................... 38

Menestho coarctata (G.O. Sars, 1878) .................................. 74

Menestho diaphana (Jeffreys, 1848)................................74, 75

Menestho divisa (J. Adams, 1797) ........................................ 75

Menestho (Liostomia) clavula ................................................ 74

Menestho (Liostomia) eburnea............................................. 74

Menestho (Liostomia) nitida................................................. 74

Menestho normani (Friele, 1886)......................................... 75

Menestho obliqua (Alder, 1844)........................................... 75 
Menestho warreni (Thompson, 1845) 75

Metzgeria alba (Wyville-Thomson, 1873).........................54

Metzgeria albella (Dunker \& Metzger, 1874)........................ 54

Mitrella rosacea (Gould, 1840) ............................................ 59

Moelleria costulata (Møller, 1842) ....................................... 24

Mohnia danielsseni (Friele, 1879)......................................... 56

Mohnia glypta (Verril, 1882)................................................ 56

Mohnia mohni (Friele, 1877)................................................. 56

Monophorus perversus (Linné, 1758) ....................................31

Nassarius arcularius (Linné, 1758) .................................... 58

Nassarius incrassatus (Strøm, 1868) .................................... 58

Nassarius nitidus (Jeffreys, 1867)....................................... 58

Nassarius pygmaeus (Lamarck, 1822)................................. 59

Nassarius reticulatus (Linné, 1758) ..................................... 58

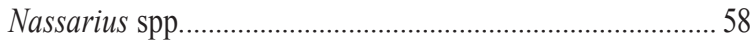

Natica bathybii Friele, 1879 ................................................ 50

Natica clausa Broderip \& G.B. Sowerby I, 1829 ................. 50

Nepotilla amoena (G.O. Sars, 1878)...................................... 66

Neptunea antiqua (Linné, 1758).......................................... 57

Neptunea despecta (Linné, 1758)........................................ 57

Neptunea (Siphonorbis) lachesis

var. bicarinata Friele, 1879 .............................................5 58

Nucella lapillus (Linné, 1758) .............................................. 52

Obtusella alderi Jeffreys, 1858 ............................................. 43

Obtusella intersecta (S.V. Wood, 1841)................................ 43

Obtusella tumidula (G.O. Sars, 1878) .................................. 43

Odostomia (Brachystomia) lukisi Jeffreys, 1858 .................. 72

Odostomia (Brachystomia) rissoides Hanley, 1844.............. 72

Odostomia (Brachystomia) eulimoides Hanley, 1844......71, 72

Odostomia acuta Jeffreys, 1848............................................ 71

Odostomia albella (Lovén, 1846)........................................... 72

Odostomia cf. angusta (Jeffreys, 1867) ................................ 71

Odostomia cf. carrozzai (van Aartsen, 1987)........................ 72

Odostomia conoidea (Brocchi, 1814)..................................... 72

Odostomia conspicua Alder, 1850 ........................................ 72

Odostomia eulimoides (Hanley, 1844)................................... 72

Odostomia lukisi Jeffreys, 1859 .............................................. 72

Odostomia nivosa (Montagu, 1803) ...................................... 70

Odostomia cf. plicata (Montagu, 1803) ................................ 72

Odostomia scalaris MacGillivray, 1843 ............................... 72

Odostomia spp...................................................................... 71

Odostomia striolata Forbes \& Hanley, 1850 ........................ 73

Odostomia sublustris Friele, 1886......................................... 70

Odostomia cf. turgida G.O. Sars, 1878 ................................ 73

Odostomia turrita Hanley, 1844 ........................................... 73

Odostomia umbilicaris (Malm, 1863) .................................. 71

Odostomia unidentata (Montagu, 1803) ............................... 72

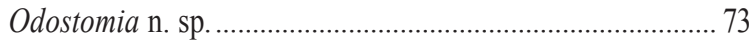

Oenopota assimilis (G.O. Sars, 1878) ................................... 61

Oenopota bergensis (Friele, 1886) ....................................... 62

Oenopota cancellata (Mighels \& Adams, 1842 ................... 62

Oenopota decussata (Couthouy, 1839).................................. 63

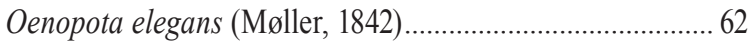

Oenopota exarata (Møller, 1842).

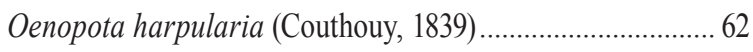

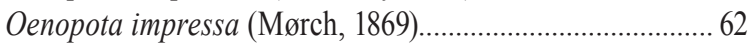

Oenopota nobilis (sensu Stokland, 1981).........................61, 63

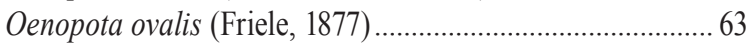

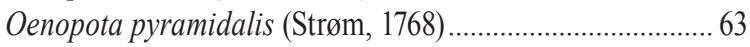

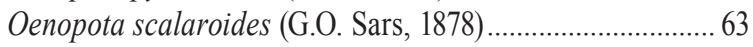

Oenopota scalaris (sensu Bouchet \& Warén, 1980)............. 61

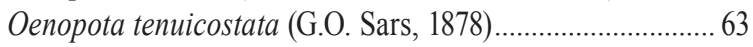

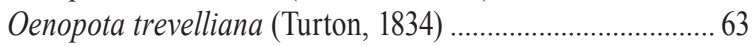

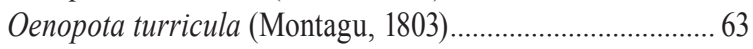

Oenopota violacea (Mighels \& Adams, 1842) ...................... 63

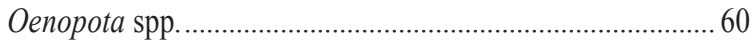

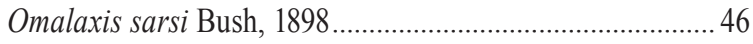

Omalaxis supranitida (S. Wood, 1848).................................. 46

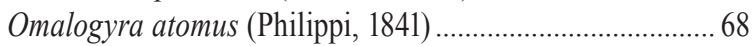

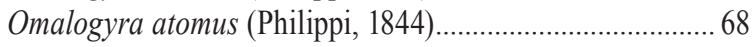

Onchidiopsis glacialis (M. Sars, 1851) ................................... 49

Ondina cf. warreni (Thompson, 1845) .................................. 75

Ondina coarctata (G.O. Sars, 1878)...................................... 74

Ondina diaphana (Jeffreys, 1848)......................................... 74

Ondina divisa (J. Adams, 1797)............................................ 75

Ondina normani (Friele, 1886) .............................................. 75

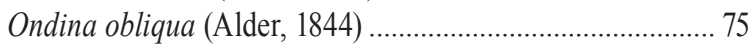

Ondina perezi (Dautzenberg \& Fischer, 1925) ..................... 75

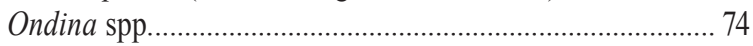

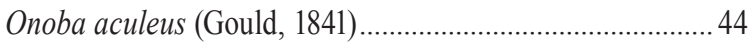

Onoba improcera Warén 1996 .................................................. 44

Onoba cf. improcera Warén 1996........................................... 44

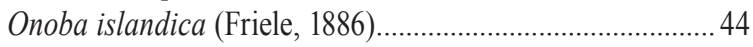

Onoba mighelsi (Stimpson, 1851).......................................... 44

Onoba semicostata (Montagu, 1803) ...................................... 44

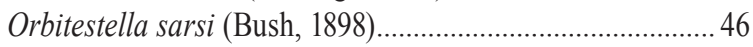

Palazzia ausonia (Palazzi, 1988) .......................................... 29

Patella aspera Röding, 1798 ..................................................17

Patella ulyssiponensis (Gmelin, 1791) ..................................17

Patella vulgata Linné, 1758.................................................17

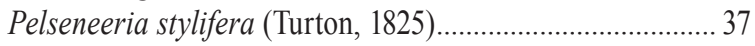

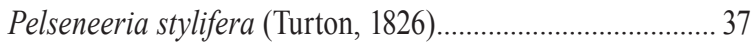

Philbertia asperrima (Brown, 1827)..................................... 65

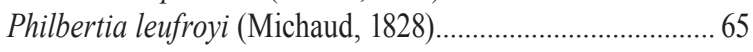

Philbertia linearis (Montagu, 1803)............................. 65, 66

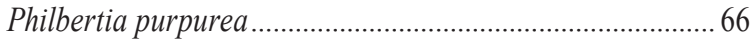

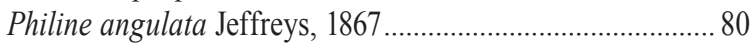

Philine aperta (Linné, 1767) .............................................. 80

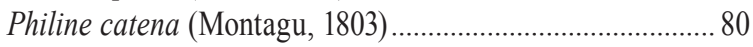

Philine denticulata (J. Adams, 1800) ................................... 80

Philine finmarchica M. Sars, 1858...................................... 80

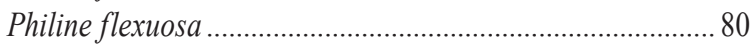

Philine infortunata Pilsbry, 1895 ......................................... 81

Philine lima (Brown, 1827) ............................................... 81

Philine loveni Malm, 1855................................................ 82

Philine pruinosa (W. Clark, 1827) ....................................... 80

Philine punctata (J. Adams, 1800) ........................................ 81

Philine quadrata (S. Wood, 1839)....................................... 81 
Philine scabra (O.F. Müller, 1784) ......................................... 82

Philine scabra Müller, 1776 ................................................... 82

Philine vitrea M. Sars............................................................. 81

Pilidium commodus Middendorff, 1851............................... 49

Piliscus radiatus (M. Sars, 1851) ........................................... 49

Pleurotomella packardi Verrill, 1872 .................................... 66

Polinices montagui (Forbes, 1838)..................................... 51

Polygireulima macrophthalmica (Warén, 1972).................... 35

Polygireulima monterosatoi (Monterosato, 1890) ................. 37

Polygireulima sinuosa (Scacchi, 1836) ................................ 37

Potamopyrgus antipodarum (Gray, 1843)............................ 45

Potamopyrgus jenkinsi (E.A. Smith, 1889) ......................... 45

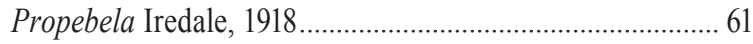

Propilidium exiguum (W. Thompson, 1844)......................... 19

Pseudacirsa coarctatum (Jeffreys, 1884).............................. 34

Pseudacirsa sarsii (Kobelt, 1905)......................................... 34

Pseudopolinices nanus (Møller, 1842)................................. 52

Pseudosetia semipellucida (Friele, 1879).............................. 44

Pseudosetia turgida (Jeffreys, 1870)................................... 45

Puncturella noachina (Linné, 1771)..................................... 20

Pusillina inconspicua (Alder, 1844)...................................... 40

Pusillina sarsii (Lovén, 1846) ................................................ 40

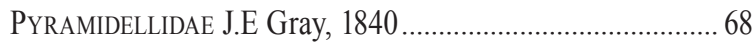

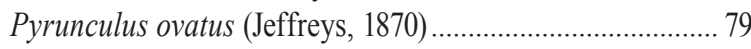

Pyrunculus ovatus (Jeffreys, 1871) ....................................... 79

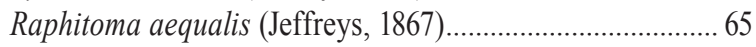

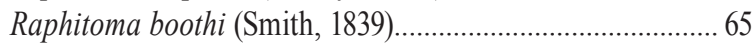

Raphitoma concinna (Scacchi, 1836)..................................... 65

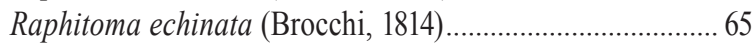

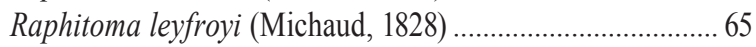

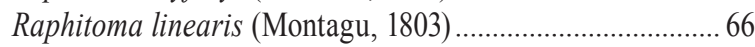

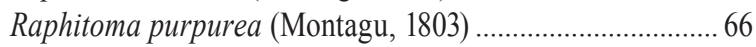

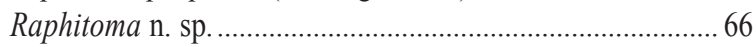

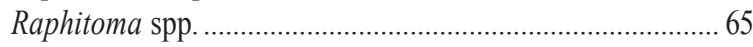

Retigyra millipunctata (Friele, 1886)................................... 29

Retusa obtusa (Montagu, 1803).............................................. 79

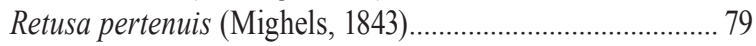

Retusa truncatula (Bruguière, 1792)..................................... 79

Retusa umbilicata (Montagu, 1803) .................................... 79

Rhinodiaphana ventricosa (Jeffreys, 1865) ........................... 78

Rissoa griegi Friele, 1879.................................................... 43

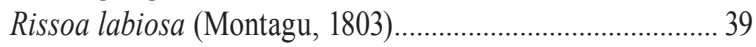

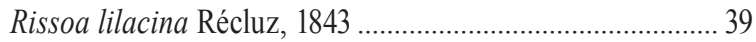

Rissoa membranacea (J. Adams, 1800) ................................. 39

Rissoa parva (da Costa, 1778)............................................... 39

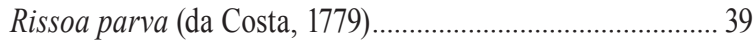

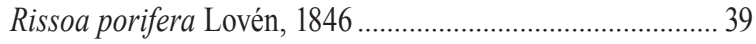

Rissoa rufilabrum (Alder, 1844) .......................................... 39

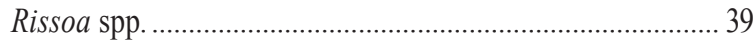

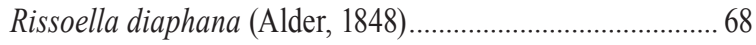

Rissoella globularis (Forbes \& Hanley, 1853) ....................... 68

Rissoella globularis (Jeffreys, 1852) ..................................... 68

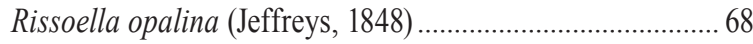

Rissopsetia cf. islandica Warén, 1989 ................................... 75
Rissostomia membranacea (J. Adams, 1800) ...................... 39

Rissostomia octona (Nilsson, 1822, not Linné, 1758)........... 39

Roxania utriculus (Brocchi, 1814).......................................... 82

Rugulina fragilis (G.O. Sars, 1878) ....................................... 30

Scabrotrophon fabricii (Møller, 1842)................................. 53

Scalaria varicosa S.V. Wood, 1842 ....................................... 34

Scaphander lignarius (Linné, 1758) ..................................... 83

Scaphander punctostriatus (Mighels \& Adams, 1842)........ 83

Scaphander spp. ............................................................... 82

Setia semipellucida (Friele, 1879) .......................................... 44

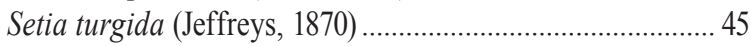

Similiphora similior (Bouchet \& Guillemot, 1978) ................31

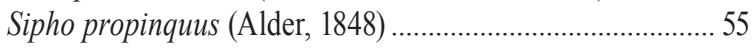

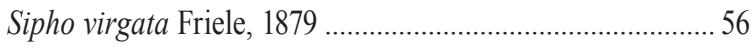

Skenea areolata (G.O. Sars, 1878) ....................................... 25

Skenea basistriata (Jeffreys, 1877) s.1................................. 25

Skenea basistriata (Jeffreys, 1877) s.str. .............................. 25

Skenea aff. proxima (Tryon 1888)................................ 25, 27

Skenea laevigata (Friele, 1876).............................................. 26

Skenea millipunctata (Friele, 1886) ...................................... 29

Skenea n.sp. A ......................................................... 25, 28

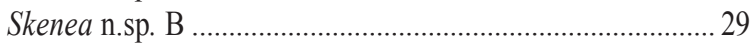

Skenea ossiansarsi Warén, 1991 ............................................ 26

Skenea peterseni (Friele, 1877) ..................................... 26, 28

Skenea polita Warén, 1993 ...................................................... 26

Skenea profunda (Friele, 1879) ............................................ 27

Skenea rugulosa (G.O. Sars, 1878)........................................ 27

Skenea trochoides (Friele, 1876)........................................... 28

Skenea turgida (Odhner, 1912).............................................. 28

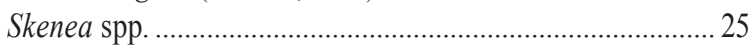

Skeneopsis planorbis (O. Fabricius, 1780) ............................ 39

Solariella affinis (Friele, 1877) ............................................. 23

Solariella amabilis (Jeffreys, 1865) ..................................... 23

Solariella cincta (Philippi, 1836) ........................................... 23

Solariella laevis Friele, 1886 ................................................ 24

Solariella obscura (Couthoy, 1838)........................................ 24

Solariella spp........................................................................ 23

Solariella varicosa (Mighels \& Adams, 1842) ..................... 24

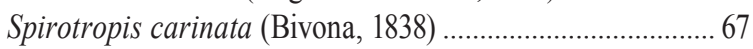

Spirotropis confusa G. Seguenza, 1880 ................................ 68

Spirotropis modiolus (de Cristofori \& Jan, 1832).................. 67

Spirotropis monterosatoi (Locard, 1897)............................... 67

Spirotropis sarsi Warén, 1975 .................................................... 67

Tacita danielsseni (Friele, 1879) ............................................ 56

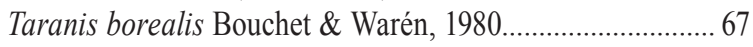

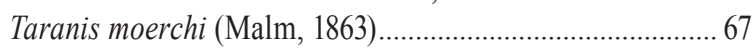

Tectura testudinalis (O.F. Müller, 1776) ..................................18

Tectura virginea (O.F. Müller, 1776)......................................18

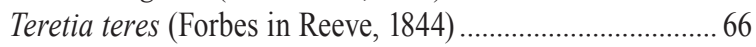

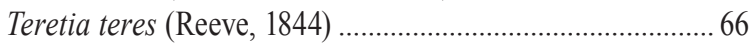

Testudinalia testudinalis (O.F. Müller, 1776)...........................18

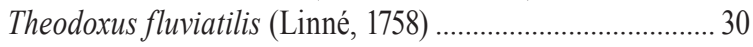

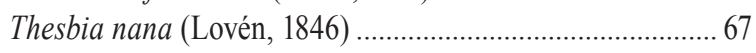

Tjaernoeia exquisita (Jeffreys, 1883) .................................. 77 
Tjaernoeia unisulcatus (Chaster, 1897) .................................. 77

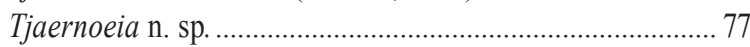

Toledonia limnaeoides (Odhner, 1913).................................. 79

Torellia delicata (Philippi, 1844) .......................................... 47

Torellia vestita Jeffreys, 1867............................................... 47

Trachysma expansa G.O. Sars, 1878....................................... 30

Trichotropis borealis Broderip \& G.B. Sowerby I, 1829 ..... 47

Trichotropis cf. borealis Broderip \& G.B.

Sowerby I, 1829 .

Trichotropis conicus Møller, 1842 ....................................... 48

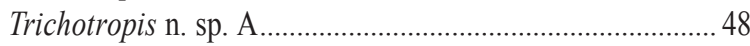

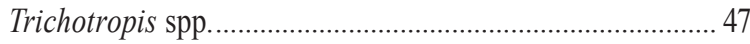

Triphora adversa (Montagu, 1803) ......................................... 30

Triphora perversa (Linné, 1758) .............................................. 30

Trivia arctica (Pulteney, 1799)............................................... 50

Trochaclis islandica Warén, 1989....................................... 30

TROPHONINAE Cossman, 1903.............................................. 52

Trophonopsis barvicensis (Johnston, 1825)............................ 52

Trophonopsis clathratus (Linné, 1767) .................................. 52

Trophonopsis clavatus (G.O. Sars, 1878)............................... 53

Trophonopsis fabricii (Møller, 1842) ..................................... 53

Trophonopsis truncatus (Strøm, 1876) ................................... 53

Troschelia berniciensis (King, 1846)...................................... 57

Turbo spiralis Montagu, 1803 ............................................... 70

Turbonilla crenata (Brown, 1827)........................................ 76

Turbonilla elegantissima (Montagu, 1803) ............................ 76

Turbonilla interrupta (Totten, 1835) ...................................... 76

Turbonilla lactea (Linné, 1767)............................................ 76

Turbonilla cf. pusilla (Philippi, 1844)................................... 76

Turbonilla rufa (Philippi, 1836) .......................................... 76

Turbonilla rufescens (Forbes, 1846) ...................................... 76

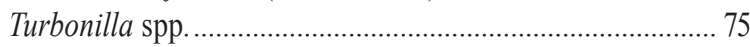

Turrisipho dalli (Friele in Tryon, 1881) ................................. 57

Turrisipho fenestratus (Turton, 1834).................................... 57

Turrisipho lachesis (Mørch, 1869)........................................ 57

Turrisipho moebii (Dunker \& Metzger, 1874) ........................ 58

Turrisipho voeringi (Bouchet \& Warén, 1985)....................... 58

Turritella communis Risso, 1826 .............................................. 30

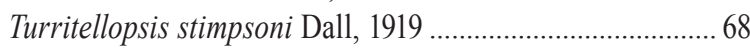

Typhlomangelia nivalis (Lovén, 1846).................................... 60

Utriculopsis vitrea M. Sars, 1870 ........................................ 78

Velutella plicatilis (O.F. Müller, 1776) .................................... 48

Velutina lanigera Møller, 1842.............................................. 48

Velutina plicatilis (O.F. Müller, 1776)................................... 48

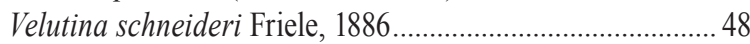

Velutina undata Brown, 1838..................................................... 49

Velutina undata J. Smith, 1839.................................................. 49

Velutina velutina (O.F. Müller, 1776) ...................................... 49

Velutininae J.E. Gray, 1840 ............................................... 48

Ventrosia ventrosa (Montagu, 1803)...................................... 46

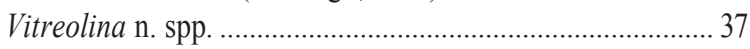

Vitreolina philippii (Rayneval \& Ponzi, 1854) ...................... 37

Volutomitra groenlandica (Møller, 1842)................................54

Volutopsius norwegicus (Gmelin, 1791)................................. 58
Volvulella acuminata (Bruguière, 1792) ............................... 79

Xylodiscula planata Høisæter \& Johannessen, 2001............. 68 